Florida International University FIU Digital Commons

2-26-2013

\title{
Ten Year Study on Water Flushing Times and Water Quality in Southern Taylor Slough, Everglades National Park, FL
}

Estefania Sandoval

Florida International University, esand002@fiu.edu

DOI: $10.25148 /$ etd.FI13042207

Follow this and additional works at: https://digitalcommons.fiu.edu/etd

\section{Recommended Citation}

Sandoval, Estefania, "Ten Year Study on Water Flushing Times and Water Quality in Southern Taylor Slough, Everglades National Park, FL" (2013). FIU Electronic Theses and Dissertations. 834.

https://digitalcommons.fiu.edu/etd/834 


\title{
FLORIDA INTERNATIONAL UNIVERSITY
}

Miami, Florida

\section{TEN YEAR STUDY ON WATER FLUSHING TIMES AND WATER QUALITY IN SOUTHERN TAYLOR SLOUGH, EVERGLADES NATIONAL PARK, FL}

\author{
A thesis submitted in partial fulfillment of \\ the requirements for the degree of \\ MASTER OF SCIENCE \\ in \\ GEOSCIENCE \\ by
}

Estefania Sandoval 
To: Dean Kenneth G. Furton

College of Arts and Sciences

This thesis, written by Estefania Sandoval, and entitled Ten YearStudy on Water Flushing Times and Water Quality in Southern Taylor Slough, Everglades National Park, $\mathrm{Fl}$, having been approved in respect to style and intellectual content, is referred to you for judgment.

We have read this thesis and recommend that it be approved.

Assefa M. Melesse

Assefa M. Melesse

Dean Whitman

René M. Price, Major Professor

Date of Defense: February 26, 2013

The thesis of Estefania Sandoval is approved.

Dean Kenneth G. Furton College of Architecture and the Arts

Dean Lakshmi N. Reddi University Graduate School

Florida International University, 2013 


\section{DEDICATION}

I want to dedicate this thesis to my parents, Jose Sandoval and Mirian Aragon, for always pushing me to obtain an education, supporting my academic endeavors, and motivating me to always push my boundaries. 


\section{ACKNOWLEDGMENTS}

I want to thank my committee members, Dr. Assefa M. Melesse and Dr. Dean Whitman for their input, suggestions, and help in guiding me on the right track for this thesis. I would like to give special thank you to my major professor, Dr. René M. Price for advising and supporting me throughout my graduate career. Opening the doors to her lab and research when I was an undergraduate student were the final motivation I needed to pursue this project. Dr. Pamela L. Sullivan was a great supporter of me and my project and I am most grateful to have had such a wonderful motivator and role model to look up to. Her added input to my research was of great help and for that, I am also thankful.

I am extremely grateful for the help I received both in the field and in the lab from David Lagomasino, Nicole Neira, Charelle Trim, Tara Verdia, Francis Matthews, Luz Espona, and my grandmother Raquel Collado. I also want to give a special thank you to Adam Hines, Olga Sanchez, Abram Da Silva, and any fellow technicians from Dr. Tiffany Troxler's lab for allowing me to tag along every month to TS/Ph-3 to collect my samples and for collecting the samples from the autosamplers in Taylor Slough and providing them to me.

I also want to thank the National Science Foundation Florida Coastal Everglades Long-Term Ecological Research Program and the Southeast Environmental Research Center for funding my project and providing financial support by offering me a Graduate Assistantship. I want to thank the staff of Everglades National Park for providing discharge data from Taylor Slough Bridge and rainfall data for various stations within the study area of my project. I am also grateful for the cooperation and availability of 
important data for my project from the United States Geological Survey, South Florida Water Management District, and Everglades National Park.

I want to give a heartfelt thank you and gratitude to my friends who never doubted me and always supported me; Rainy Kinchen, Lyndarubi Ferretti, Maura Taveras, Yorlenis Rodriguez, Marlene Oria, Vanessa Gomez, Emanuelle Feliciano, Lilian Marrero, Stephanie Long, Michael Mondragon, Maria Herrera, Jose Trujillo, Luz Espona and her wonderful family, and Cindy Perez and her loving family. My final thank you is for my family and their unwavering support: my mother Mirian Aragon, my father Jose Sandoval, my grandmothers Raquel Collado and Aridia Sandoval, and my siblings Ariel Sandoval, Jonathan Sandoval, Sebastian Sandoval, Genesis Sandoval, Gabriel Sandoval, and Alanis Sandoval. Thank you all for helping me reach this milestone, one or way or another. 


\begin{abstract}
OF THE THESIS
TEN YEAR STUDY ON WATER FLUSHING TIMES AND WATER QUALITY IN SOUTHERN TAYLOR SLOUGH, EVERGLADES NATIONAL PARK, FL
\end{abstract}

by

\title{
Estefania Sandoval
}

Florida International University, 2013

Miami, Florida

\section{Professor René M. Price, Major Professor}

The purpose of this research was to investigate the effects of wetland restoration on the water balance, flushing time, and water chemistry of southern Taylor Slough, a major water way in Everglades National Park. Water balance and flushing time equations were calculated on a monthly time step from 2001 - 2011. Water chemistry of major ions and nutrients were analyzed and correlated with water flushing times. Results showed that evapotranspiration followed by water volume had the greatest influence on flushing time. The flushing times varied between 3 and 78 days, with longer times observed between October and December, and the shorter times between March and May. Ion concentrations at the coastal areas decreased with increased flushing times. Increased surface water inflow that resulted from restoration projects and water management changes were productive in the rainy season and should result in increased flushing times and decreased ion concentrations in Taylor Slough. 


\section{TABLE OF CONTENTS}

CHAPTER

PAGE

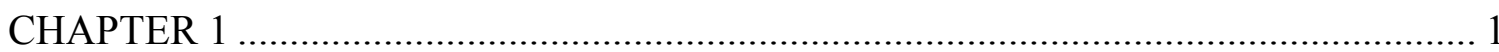

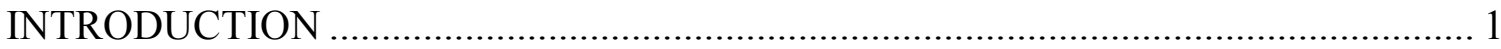

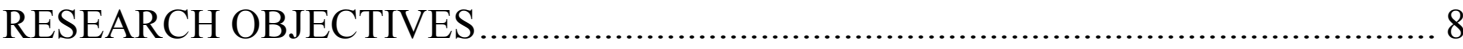

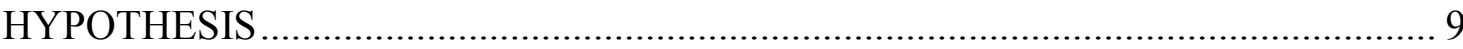

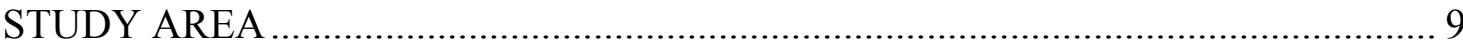

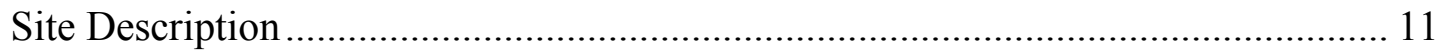

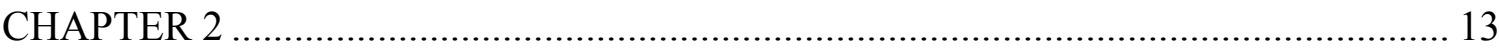

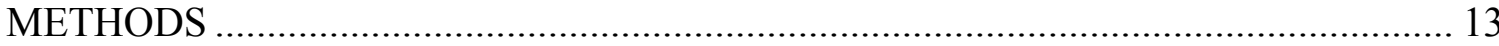

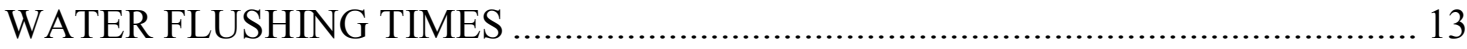

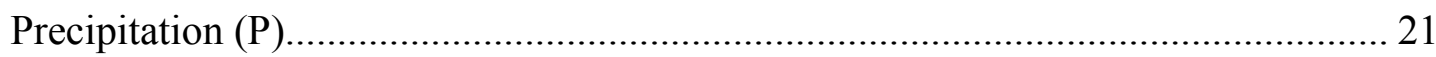

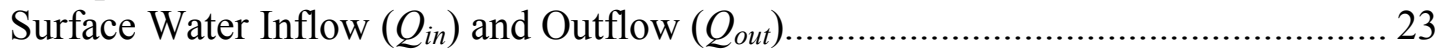

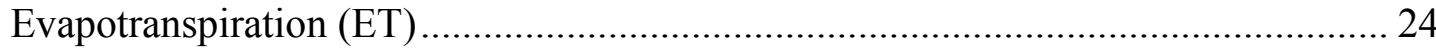

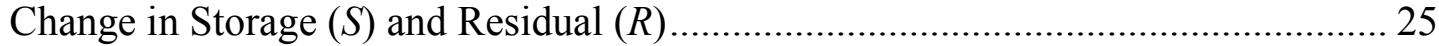

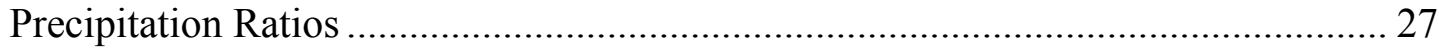

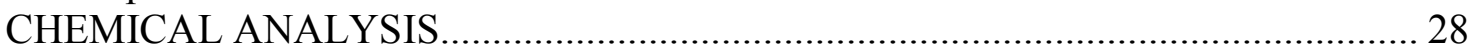

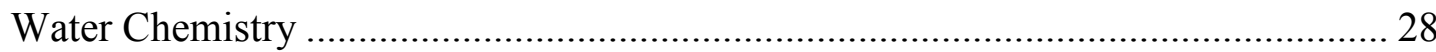

Stable Isotopes of oxygen and hydrogen................................................................ 31

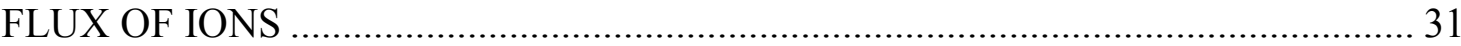

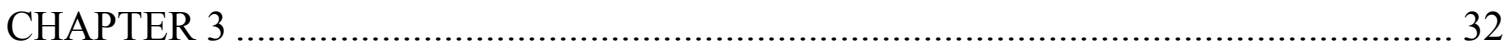

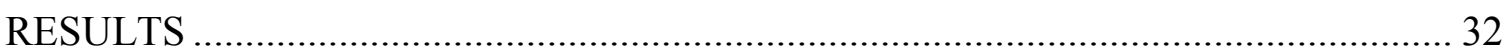

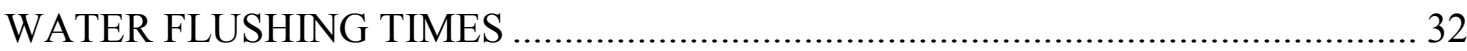

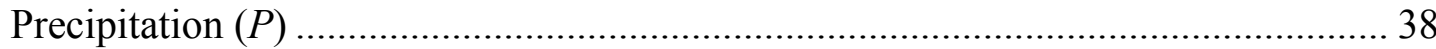

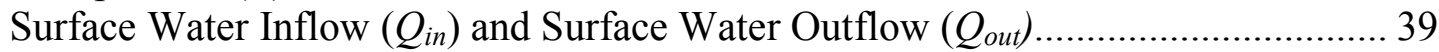

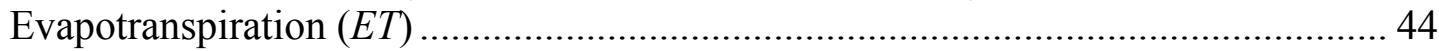

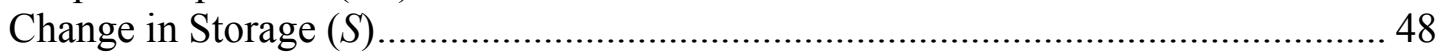

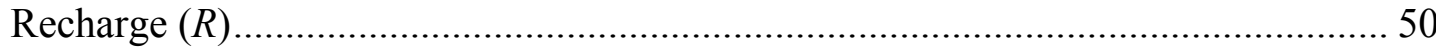

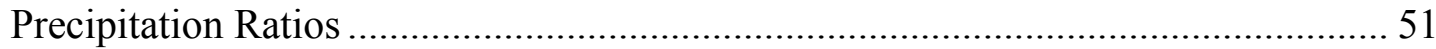

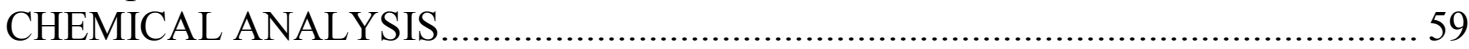

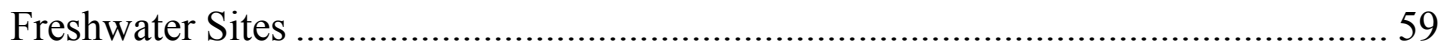

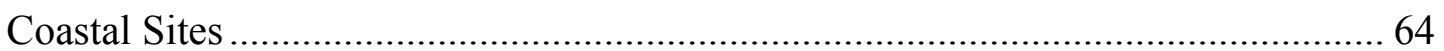

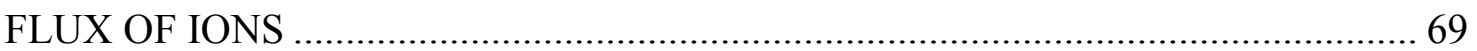

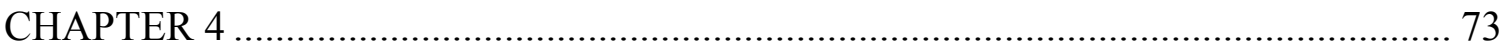

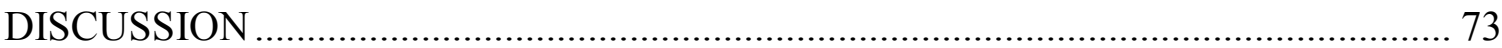

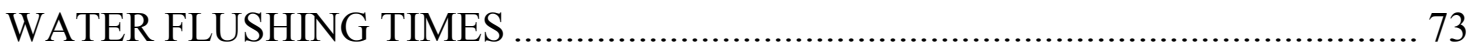

WATER CHEMISTRY AND FLUSHING TIMES …………..................................... 77

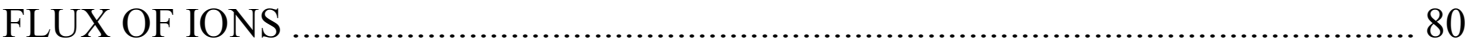




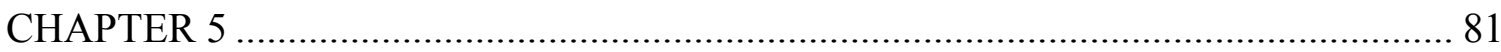

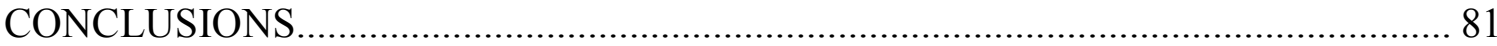

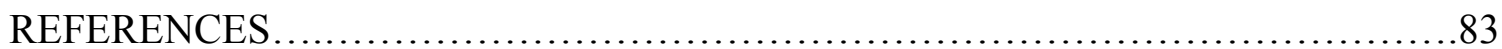

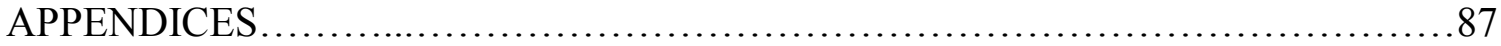




\section{TABLE OF FIGURES}

FIGURE

PAGE

Figure 1.1. Difference between Age, Residence Time, and Transit Time of a particle within a body of water (the green outline define the water body's boundary) ............ 2

Figure 1.2. The Everglades from Lake Okeechobee, Everglades Agricultural Area (EAA), Water Conservation Areas (WCA), and into Everglades National Park (ENP).

Southern Taylor Slough area is shown in red.

Figure 1.3. Southern Taylor Slough and the canals and pumps in close proximity to the study area.

Figure 1.4. The FCE/LTER Taylor Slough sites used in this study. The freshwater sites are TS/Ph-1, TS/Ph-2, and TS/Ph-3. The coastal sites are TS/Ph-6 and TS/Ph-7.... 12

Figure 2.1. Southern Taylor Slough and the 37 EDEN gaging stations used in the study. The National Atmospheric Deposition Program site FL11 and Royal Palm Ranger Station (RPL) are also shown.....

Figure 2.2. Flow chart of GIS processes to obtain water depth raster (WDYYMM01) and rasters (EYYMM01) used for Volume (V) of the flushing time calculation. 16

Figure 2.3. Rasters of Taylor Slough (A)Surface water level (meters), (B) water depth (meters), and (C) water depth raster with only grids containing values greater than zero (meters). The red outline and shading labels the area of southern Taylor Slough.

Figure 2.4. The overall extent of the HAED Project in the Everglades and a close-up of southern Taylor Slough study area.................................................................... 20

Figure 2.5. DEM created using the HAED data (meters) ....................................... 20

Figure 2.6. (A) Thiessen Polygon of southern Taylor Slough using the 37 EDEN stations

Figure 2.7. (A) Thiessen Polygon of southern Taylor Slough using 10 stations from ENP, SFWMD, and NOAA for 2001 and the (B) rasterized version of the Thiessen Polygon.

Figure 2.8. Raster layer of ET created using Spatial Analyst Kriging tool................266

Figure 2.9. Flow chart of raster processes to obtain change in storage $(\mathrm{S})$ rasters 27

Figure 2.10. GIS raster layer of water depth layer used to obtain change in storage where 
Figure 3.1. Daily water flushing times for southern Taylor Slough from January 1, 2008 to July 31,2009 33

Figure 3.2. Water flushing times for weekly, bi-weekly, and monthly time-scales for January 1, 2008 - July 31, 2009. Monthly time-scale flushing times using data collected for this study is depicted in navy blue (ES).

Figure 3.3. Taylor Slough average flushing times (days) by month for $2001-2011$ with standard error bars.

Figure 3.4. Taylor Slough monthly flushing times (days) from January 2001 - December 2011. 35

Figure 3.5. Taylor Slough yearly average flushing times with standard error bars for 2001 -2011 . 36

Figure 3.6. Monthly average volume, $V$, (triangle) and flushing time, $\mathrm{T}_{\mathrm{f}}$, (diamond) for southern Taylor Slough with standard error bars for January 2001 - December 2011.

Figure 3.7. Monthly volume for southern Taylor Slough for January 2001 - December 2011.

Figure 3.8. Yearly total volume for southern Taylor Slough for $2001-2011$.

Figure 3.9. Volume vs. Flushing times for southern Taylor Slough for January 2001 -

December 2011. 38

Figure 3.10. Mean monthly rainfall (cm) for southern Taylor Slough from $2001-2011$. Standard error bars for the mean rainfall are smaller than the labels. The solid line represents the 30-year mean monthly average for Royal Palm Ranger Station (RPL) from $1970-2011$ and the dashed lines represent the + standard error for RPL....... 39

Figure 3.11. Taylor Slough total monthly precipitation from January 2001 - December 2012.

Figure 3.12. Total annual precipitation (cm) for southern Taylor Slough. The 30-year yearly average with standard error lines for RPL is also shown.

Figure 3.13. Average monthly surface water inflows from TSB for $2001-2011$ with standard error bars.

Figure 3.14. Monthly surface water inflow from TSB from January 2008 to December 2011. 
Figure 3.15. Yearly total sums of surface water inflow from TSB into southern Taylor Slough for $2001-2011$..................................................................................... 42

Figure 3.16. Average monthly surface water outflow (with standard error bars) for southern Taylor Slough from January 2001 - December 2011. Positive values indicate surface water flowing into Taylor Slough from Florida Bay; Negative values indicate surface water flowing out of Taylor Slough to Florida Bay.

Figure 3.17. Monthly surface water outflow for southern Taylor Slough from January 2001 - December 2011. Positive values indicate surface water flowing into Taylor Slough from Florida Bay; Negative values indicate surface water flowing out of Taylor Slough to Florida Bay.

Figure 3.18. Total yearly sums of surface water discharge for southern Taylor Slough for $2001-2011$

Figure 3.19. Monthly surface water inflow (Qin) and absolute values of surface water outflow (Qout) from January 2001 - December 2011 for Taylor Slough. 45

Figure 3.20. Monthly average evapotranspiration (square) and water flushing times (diamond) for southern Taylor Slough with standard error bars for January 2001 December 2011.

Figure 3.21. Monthly evapotranspiration for southern Taylor Slough for January 2001 -

December 2011

Figure 3.22. Yearly total sums of evapotranspiration for southern Taylor Slough for 2001 $-2011$.

Figure 3.23. Evapotranspiration vs. Flushing times for southern Taylor Slough for January 2001 - December 2011

Figure 3.24. Monthly average values for change in storage (S) and groundwater (GW) with standard error bars for southern Taylor Slough for January 2001 - December 2011. Positive GW values indicate groundwater discharging into Taylor Slough while negative values indicate surface water recharging the groundwater.

Figure 3.25. Monthly change in storage (S) values for southern Taylor Slough for January 2001 - December 2011.

Figure 3.26. Yearly total sums of change in storage for southern Taylor Slough for 2001 $-2011$

Figure 3.27. Monthly groundwater $(\mathrm{GW})$ values for southern Taylor Slough from January 2001 - December 2011. Positive GW values indicate groundwater discharging into Taylor Slough while negative GW values indicate Taylor Slough surface water is recharging the groundwater 
Figure 3.28. Total yearly sums of groundwater (GW) for southern Taylor Slough from $2001-2011$.

Figure 3.29. Monthly average of the surface water inflow at TSB and precipitation at TSB relationship ratio for $2001-2011$ with standard error bars................................ 52

Figure 3.30. Monthly surface water inflow - precipitation at TSB ratio for January 2001 December 2011 53

Figure 3.31. Cumulative rain vs. surface water inflow at TSB for January $2001-$ December 2011. Rain from TSB station (aqua) and Royal Palm Ranger Station (purple) are shown. 53

Figure 3.32. Surface water discharge at S332 vs. surface water discharge at TSB for January 2001 - December 2011 54

Figure 3.33. Rainfall at TSB vs. surface water discharge at TSB for January $2001-$ December 2011. 54

Figure 3.34. Monthly surface water outflow - precipitation ratio (absolute value) for

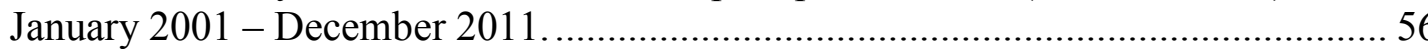

Figure 3.35. Monthly surface water outflow - precipitation ratio for January 2001 December 2011. 56

Figure 3.36. Cumulative rain vs. surface water outflow for January 2001 - December 2011. 57

Figure 3.37. Surface water outflow vs. Precipitation for southern Taylor Slough for January 2001 - December 2011.

Figure 3.38. Monthly change in storage - precipitation ratio (absolute value) for January 2001 - December 2011. 58

Figure 3.39. Monthly Change in storage vs. Precipitation for southern Taylor Slough for January 2001 - December 2011 58

Figure 3.40. Change in storage vs. Precipitation for southern Taylor Slough for January 2001 - December 2011.

Figure 3.41. Monthly average surface water cation concentrations of (A)Sodium, (B) Potassium, (C) Magnesium, and (D)Calcium for the freshwater sites (TS/Ph-1, $\mathrm{TS} / \mathrm{Ph}-2$, and TS/Ph-3) of southern Taylor Slough with standard error bars. Data ranges from August 2008 to December 2011. Water flushing times (grey diamond) for August 2008 - December 2011 are also shown.

Figure 3.42. Monthly average surface water anion concentrations of (A) chloride and (B) 
sulfate for freshwater sites (TS/Ph-1, TS/Ph-2, and TS/Ph-3) of southern Taylor Slough with standard error bars.

Figure 3.43. Monthly average Total Nitrogen (TN) for freshwater sites (TS/Ph-1, TS/Ph2, TS/Ph-3) in southern Taylor Slough for 2003 - 2011. Monthly average flushing times are also shown.

Figure 3.44. Monthly average Total Phosphorus (TP) for freshwater sites (TS/Ph-1, $\mathrm{TS} / \mathrm{Ph}-2$, and TS/Ph-3) in southern Taylor Slough for 2003 - 2011. Monthly average flushing times are also shown. 63

Figure 3.45. Average values of stable isotopes of oxygen and hydrogen for the freshwater sites (TSB, TS/Ph-1, TS/Ph-2, TS/Ph-3) spanning from 1998/1999 to 2012 with standard error bars. Slope for the global meteoric water line is $y=8 x+10$.

Figure 3.46. Monthly average surface water cation concentrations of (A)Sodium, (B) Potassium, (C) Magnesium, and (D)Calcium for the coastal sites (TS/Ph-6 and $\mathrm{TS} / \mathrm{Ph}-7)$ of southern Taylor Slough with standard error bars. Data ranges from January 2008 to December 2011.

Figure 3.47. Monthly average surface water anion concentrations of (A) chloride and (B) sulfate for the coastal sites (TS/Ph-6 and TS/Ph-7) in southern Taylor Slough with standard error bars.

Figure 3.48. Monthly average Total Nitrogen of the coastal sites (TS/Ph-6 and TS/Ph-7) of southern Taylor Slough from 2001 - 2010 with standard error bars. Water flushing times (blu diamond) are also graphed with standard error bars. 68

Figure 3.49. Monthly average Total Phosphorus of the coastal sites (TS/Ph-6 and TS/Ph7) of southern Taylor Slough from 2001 - 2011 with standard error bars. Water flushing times (blue diamond) are also graphed with standard error bars.

Figure 3.50. Southern Taylor Slough ion flux for (A) chloride and (B) calcium multiplied by precipitation $(\mathrm{P})$, surface water inflow (Qin), Groundwater (GW) at TSB and TS3.

Figure 3.51. Chloride (meq/L) and stable isotopes of oxygen (\%o) for the freshwater sites of southern Taylor Slough. Chloride values for TS/Ph-3 groundwater (TS3_GW) for 2009 and 2012 were higher than the other samples and are labeled.

Figure 3.52. Calcium (meq/L) and stable isotopes of oxygen (\%o) for the freshwater sites of southern Taylor Slough.

Figure 3.53. Chloride and calcium ion concentration averages for the freshwater sites of southern Taylor Slough. Groundwater at TS3 for 2009 and 2012 had ion values higher than the other samples and are labeled..... 
Figure 4.1. Monthly averages of ET (square), Volume (triangle), and Flushing Times (diamond) for southern Taylor Slough for January 2001 - December 2011 with standard error bars.

Table 1. Table of acronyms

\begin{tabular}{|l|l|}
\hline Acronym & Name \\
\hline AHF & Airborne Height Finder \\
\hline BCNP & Big Cypress National Preserve \\
\hline CERP & Comprehensive Everglades Restoration Plan \\
\hline DEM & Digital Elevation Model \\
\hline EDEN & Everglades Depth Estimation Network \\
\hline EMER & Everglades Mangrove Ecotone Region \\
\hline ENP & Everglades National Park \\
\hline EOM & End of Month \\
\hline ET & Evapotranspiration \\
\hline FAWN & Florida Automated Weather Network \\
\hline FCE & Florida Coastal Everglades \\
\hline FPDA & Frog Pond Detention Area \\
\hline GDM & Gautier-Diak-Masse \\
\hline GIS & Geographic Information System \\
\hline GOES & Geostationary Operational Environmental Satellite \\
\hline GW & Groundwater \\
\hline HAED & High Accuracy Elevation Dataset \\
\hline LTER & Long Term Ecological Research \\
\hline MC & Mud Creek \\
\hline MCC & McCormick Creek \\
\hline NAD83 & North American Datum 1983 \\
\hline NADP & National Atmospheric Deposition Program \\
\hline NAVD 88 & North American Vertical Datum 1988 \\
\hline NEXRAD & Next Generation Radar \\
\hline NOAA & National Oceanic and Atmospheric Administration \\
\hline NTN & National Trends Network \\
\hline P & Precipitation \\
\hline PET & Potential Evapotranspiration \\
\hline PT & Priestley-Taylor \\
\hline Qin & Surface water inflow \\
\hline Qout & Surface water outflow \\
\hline QTout & Total output \\
\hline R & Error \\
\hline RPL & Royal Palm Station \\
\hline S & Change in Storage \\
\hline SERC & Southeast Environmental Research Center \\
\hline SFWMD & South Florida Water Management District \\
\hline & \\
\hline
\end{tabular}




\begin{tabular}{|l|l|} 
SJRWMD & St. John's River Water Management District \\
\hline TN & Total Nitrogen \\
\hline TP & Total Phosphorus \\
\hline TR & Taylor River \\
\hline TSB & Taylor Slough Bridge \\
\hline UF IFAS & University of Florida Institute of Food and Agricultural Sciences \\
\hline USGS & United States Geological Survey \\
\hline WSR-88D & Weather Surveillance Radar 88 Doppler \\
\hline
\end{tabular}




\section{CHAPTER 1}

\section{INTRODUCTION}

Water renewal time measurements are typically made in a diverse array of studies, from biological to hydrologic to geochemical to name a few (Monsen et al. 2002) The common goal of water renewal time measurements is to quantify the amount of time water remains inside a specified boundary (i.e. a watershed/boundary). Water renewal times are often expressed as "age", "residence time", "transit time", and/or "flushing time" which because of their interrelationship, are often expressed with differing and often contradictory concepts and definitions in the literature (Bolin and Rodhe 1973, Huang 2007, Monsen et al. 2002) . In general, the terms age, residence time, and transit time are focused on specific molecules, i.e., of water, entering and/or within the defined boundaries while flushing times focuses on the total volume of water within the defined boundaries. Age focuses on the time the molecule has spent within a system since its entrance. Residence time focuses on the time the molecule takes to exit the system from a starting point that is not necessarily the entrance. Transit time is the amount of time the molecule takes to exit the system from the entrance (Figure 1.1). Unlike age, residence time, and transit time, flushing time is a system-level measure that focuses on the general exchange characteristics of the system without taking into consideration smaller scale physical processes and their relative importance (Monsen et al. 2002). Age and residence time are locally focused and spatially variable within the system, while flushing time and transit time are system wide. All these transport time measurements contain underlying assumptions that need to be considered when applying to a real system. Much of the literature on water renewal times have been performed in 
watershed/estuary environments with a main surface water river input to the study area.

In comparison, the remnant Everglades, and this research's study area Taylor Slough, has a main surface water input that is trickle-fed by water management.

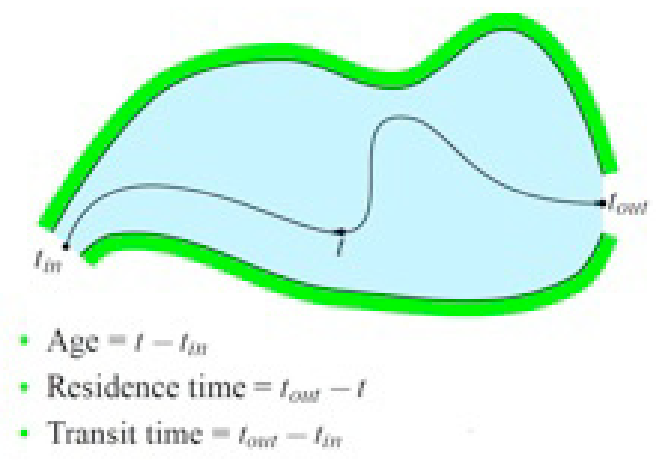

Figure 1.1. Difference between Age, Residence Time, and Transit Time of a particle within a body of water (the green outline define the water body's boundary). Age and Residence Time take into consideration the particle's time at any given location within the body of water $(t)$, with Age looking at $t$ - initial time $\left(t_{i n}\right)$ and Residence Time at time when the particle exits the system $\left(t_{\text {out }}\right)-t$. Transit time only focuses on $t_{\text {in }}$ and $t_{\text {out }}$. Image source: Constituent-oriented Age and Residence time Theory (CART) http://www.elic.ucl.ac.be/repomodx/cart/

Since drainage first began in the 1880 s, urbanization and water management practices have altered the natural flow of the Everglades with most cases resulting in a decrease of water flow across the system. Today, the Everglades have been reduced to half its original size (Holling et al. 1994) with the most 'intact' portion of the Everglades located in what is now Everglades National Park (ENP) (Figure 1.2) (Table 1). The alterations have led to changes in the hydrologic conditions as well as the topography of the Everglades including an increase in groundwater-surface water interactions, groundwater recharge outside of the Everglades, degradation of water quality, peat subsidence and a decrease in the number of tree islands to name a few (Harvey and 
McCormick 2009). These changes resulted in degradation of the ecosystem, productivity, and biodiversity (Boesch et al. 1993). Efforts to improve the condition of the Everglades have progressed slowly since the passage of the Comprehensive Everglades Restoration Plan (CERP) in 2000, which includes approximately 60 projects that are to be constructed in the following 30 years (Sklar et al. 2005). The lag in the progression of restoration projects includes conflict of interests amongst different groups, funding for such projects, and the uncertainty of ecological benefits of the projects (Sklar et al. 2005). Current restoration efforts have the final goal of restoring natural flow and clean water into the Everglades to an almost pre-anthropogenic state while also balancing flood control and water supply needs of the population of south Florida (Hollander 2008, Kirsch 2004, Ogden 2008). 


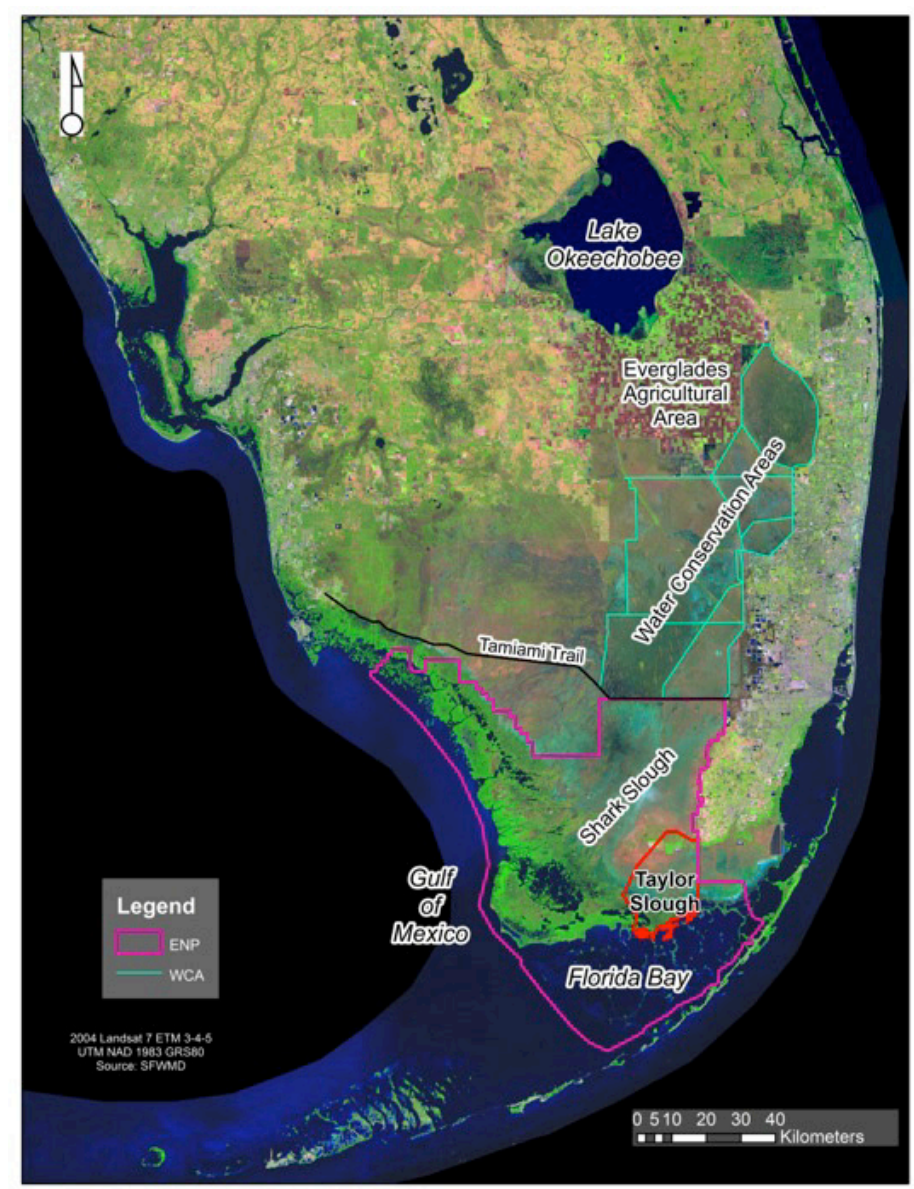

Figure 1.2. The Everglades from Lake Okeechobee, Everglades Agricultural Area (EAA), Water Conservation Areas (WCA), and into Everglades National Park (ENP). Southern Taylor Slough area is shown in red.

One of the main goals of CERP is to increase freshwater flow into Florida Bay through its main contributor, Taylor Slough (Figure 1.3). Projects emphasizing increasing freshwater flow through Taylor Slough include the C-111 Spreader Canal Project and Modified Water Deliveries to ENP Project. One task completed under these projects included raising and lengthening of Taylor Slough Bridge in 2001 to allow a more natural flow of surface water between the northern and southern portions of Taylor Slough. The S332D canal structure located at the northern headwaters of Taylor Slough (Figure 1.3) 
was completed in 1999 as part of the Water Resources Development Act of 1996. The completion of the S332B (2000) and S332C (2002) detention areas north of S332D were completed to prevent seepage out of ENP to lands east of the L-31N canal with the goal to increase flows into Taylor Slough by creating a hydraulic ridge. The C-111 Spreader Canal Project, which includes additional pump stations, culverts and water control structures south of the detention areas and east of Taylor Slough, also has the goal of preventing seepage out of ENP with increasing sheet flow to Florida Bay via Taylor Slough. The C-111 Spreader Canal Project's goal is to create a nine-mile hydraulic ridge that would continue from the northern S332 detention areas. The finalized project will have created a 590-acre detention area south of S332D, named the Frog Pond Detention Area (FPDA), and installed the S-199 and S-200 pump stations (Figure 1.3). The initial components of the C-111 Spreader Canal project were completed in 2001 with the construction of the S-199 and S-200 pump stations. 


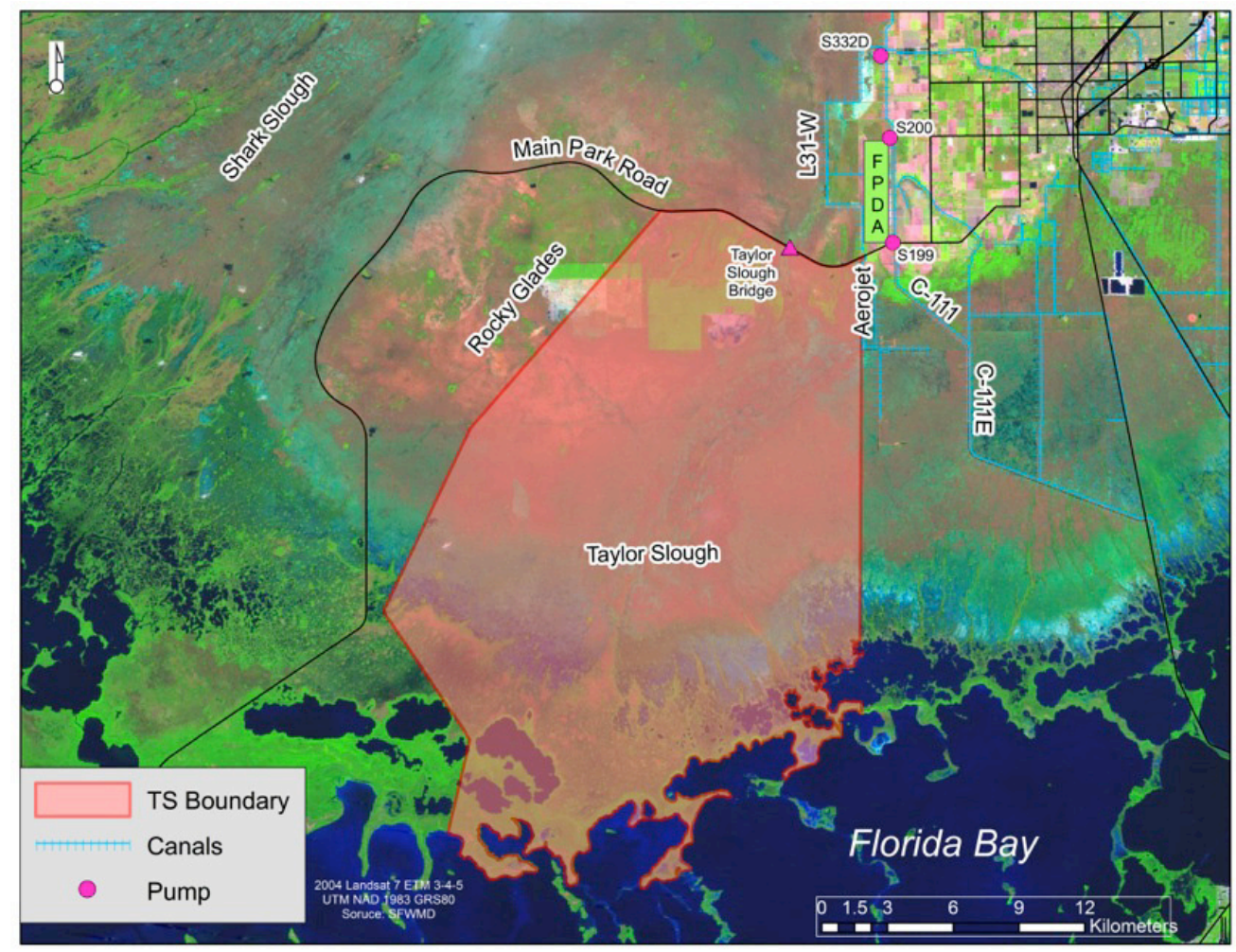

Figure 1.3. Southern Taylor Slough and the canals and pumps in close proximity to the study area.

Previous studies in Taylor Slough included (Sutula et al. 2001), who calculated hydrologic and nutrient budgets over one and a half years. Their work concluded that surface water flow and precipitation were the main contributors to the water budget. Atmospheric deposition was found to be the dominant source of phosphorus and, along with surface water, of nitrogen input to the Taylor Slough region. The findings of Sutula et al. (2001) supported previous works that signaled to atmospheric deposition's significance to nutrient inputs in oligotrophic ecosystems (Cole et al. 1990, Jassby et al. 1995, Prospero et al. 1996). Koch et al. (2012) investigated the hydrological inputs of phosphorus and their importance to the oligotrophic Everglades, focusing on three Taylor River ponds. Using hydrologic and water quality variables, water residence time 
estimation, groundwater sampling, and net ecosystem production, their study showed a correlation between surface water phosphorus concentrations with decreased surface water flow rates and increasing salinity concentrations in Taylor River. High ecosystem metabolism rates correlated with increased upstream total phosphorus (TP), salinity, and groundwater discharge to surface water. The findings supported Childers et al. (2006) conclusion of the Everglades' being an "upside-down" estuary with the limiting nutrient, phosphorus, supplied by marine and groundwater sources (Price et al. 2010) as opposed to upstream anthropogenic sources.

Zapata-Rios and Price (2012) investigated groundwater/surface water interactions between 2008 and 2009 and determined that groundwater discharge accounted for $27 \%$ of the input to Taylor Slough with peaks in July 2008 and May 2009. Michot et al. (2011) developed a hydrodynamic model of a small section in southern Taylor Slough from hydrologic data ranging from 1999 - 2007. Their model suggested that overland flow was the main contributor to the water budget with precipitation and evapotranspiration playing a secondary role. Groundwater data pointed to a possible connection with evapotranspiration. Although previous work identified the dominant parameters of the water budget for Taylor Slough, those studies were limited in either area or time, and lacked information on the effects of water management practices on the water budget parameters as well as on the water chemistry and nutrient data of Taylor Slough. The work performed herein, will help improve understanding of Taylor Slough's hydrologic components in response to restoration efforts. Understanding the hydrologic conditions of a wetland ecosystem is also important for discerning other important variables such as 
productivity, organic matter accumulation, nutrient cycling and transport to name a few (Sutula et al. 2001).

\section{RESEARCH OBJECTIVES}

Taylor Slough has undergone past, as well as current and future restoration efforts. One way to assess the success of restoration in the area is to observe long-term hydrological and geochemical changes as the projects have undergone completion. The purpose of this research was to investigate the effects of restoration on the water balance, flushing time, and water chemistry of Taylor Slough. Understanding past and present hydrological and geochemical conditions of Taylor Slough will not only give insight to the success of current and future restoration efforts, but may also provide an understanding of how other variables such as climate change and sea level rise may affect the study area. Specific objectives of this research were to:

- Determine the water flushing time of Taylor Slough

- Observe possible correlations between flushing times, surface water chemistry, and analyzed nutrient data

- Identify the dominant sources of ions in Taylor Slough.

Research questions that were addressed through this research included the following:

- How has the flushing time in Taylor Slough varied in the last decade (2001-2011)?

- How did the major ion concentrations and nutrient analysis of Taylor Slough correlate with the calculated flushing times?

- What were the dominant sources of ions in Taylor Slough? 


\section{HYPOTHESIS}

The specific hypotheses addressed in this research included:

- Increasing surface water flow because of changes in water management practices would result in a decrease in the water flushing time of Taylor Slough;

- Both major ion concentrations and nutrient values would have a positive correlation with the water flushing times; and

- The flux of ions going into Taylor Slough would be greatest from groundwater inputs.

\section{STUDY AREA}

The Everglades ecosystem, extending from Lake Okeechobee in central Florida to Florida Bay (Figure 1.2), is a dominantly freshwater-coastal wetland with a subtropical climate distinguished by a wet summer season, and a relatively dry winter season. The Everglades is an oligotrophic system with phosphorus being the limiting macronutrient (Noe et al. 2001). The Everglades has two main natural waterways, the larger Shark Slough discharges into the Gulf of Mexico with the smaller Taylor Slough discharging into Florida Bay. Both sloughs are located within ENP. Taylor Slough, which is the focus of this study, extends approximately 20-30 kilometers from the northern end along the northeastern boundary of ENP down to Florida Bay (Figure 1.3) (Armentano et al. 2006, Zapata-Rios 2009). The headwaters begin in the Rocky Glades; a slightly topographically higher 'outcrop' that is part of the southern Atlantic Coastal Ridge. Taylor Slough transitions from a sawgrass (Cladium jamaicense) and freshwater emergent vegetation 
dominated landscape (Armentano et al. 2006) to a transition zone where this freshwater landscape intermixes with dwarf red mangroves (Rhizophora mangle) to the brackish coastal area where the dwarf red mangrove predominates. The Florida Coastal Everglades (FCE) Long Term Ecological Research (LTER) program has named the mangrovedominated ecotone area in both Taylor Slough and Shark Slough as the Everglades Mangrove Ecotone Region (EMER, (Rivera-Monroy et al. 2011). The EMER in Taylor Slough channelizes surface water flow into five major creek systems; McCormick Creek, Taylor River, Mud Creek, Trout Creek, and West Highway Creek cross through Buttonwood Ridge. Buttonwood Ridge has higher topographical relief that restricts overland flow, except during events like storm surges when overtopping may occur (Langevin et al., 2004). The result being freshwater input to Florida Bay from Taylor Slough is restricted to just these five creeks (Sutula et al. 2001).

The Main Park Road, physically divides the northern and southern regions of Taylor Slough (Figure 1.3). Northern Taylor Slough incorporates the S-332 detention basins, which are managed to receive and store water pumped from the L-31 canal, and then transmit it along with any received rainfall to southern Taylor Slough beneath the Taylor Slough Bridge (TSB). The majority of Taylor Slough is located in southern Taylor Slough and is the focus of this work. Previous works have defined the area of southern Taylor Slough as approximating $446 \mathrm{~km}^{2}$, using the physical boundaries as the Main Park Road to the north, the L-31W canal to the east, Florida Bay to the south, and the Rocky Glades as the western boundary (Zapata-Rios and Price 2012). Construction of the L-31W canal severely restricted the natural flow of water into southern Taylor Slough, with the S332D pump station (Figure 1.3) located in northern Taylor Slough now 
being the major contributor of water flow into the system. The C-111 canal structure also manipulates flow into southern Taylor Slough (Armentano et al. 2006, Tillis 2001, Zapata-Rios 2009).

Site Description

The FCE/LTER has both freshwater and coastal sites in the study area (Figure 1.4). The FCE/LTER TS/Ph stations consist of a platform that supports an ISCO 6172 Full-Size Portable Sampler (ISCO Sampler) and a rain gauge. Data collections at the FCE/LTER sites commenced in the year 2001 through present day; the freshwater sites, $\mathrm{TS} / \mathrm{Ph}-1$ and $\mathrm{TS} / \mathrm{Ph}-2$, are located in the northern portion of the study area. The northernmost site, TS/Ph-1 is located by the L-31W canal while TS/Ph-2 is in close proximity of Taylor Slough Bridge (TSB) by the Main Park Road, approximately a five minutes drive by car west of the entrance to the park. Pump stations S332D, S332B, S332B2, S332C, and S175C are located in the S332 retention pond areas composing the eastern border of northern Taylor Slough. Surface water levels at TSB are monitored continuously (every 30 minutes) by an automated device that is operated by personnel from Everglades National Park. Northern Taylor Slough often dries out during the dry season, although a remnant 'pond' was always observed underneath the bridge at TSB during this study. Surface water and groundwater samples were collected at TSB during field campaigns. Surface water and groundwater are fresh at northern Taylor Slough and the dominant vegetation is sawgrass (Cladium jamaicense).

Within the study area, TS/Ph-3 is centrally located at what is considered the northern end of the EMER of Taylor Slough. At this site, the dominant vegetation still 
consists of sawgrass and muhly grass (Muhlenbergia filipes), but there is also the presence of dwarf red mangroves (Rhizophora mangle). Site TS/Ph-3 dries down during the dry season, with access available via airboat (in the wet season) or helicopter (in the dry season). Surface water and groundwater samples were collected at TS/Ph-3 during field campaigns performed through airboat transportation when surface water was available. Surface water at $\mathrm{TS} / \mathrm{Ph}-3$ is fresh while the groundwater is brackish.

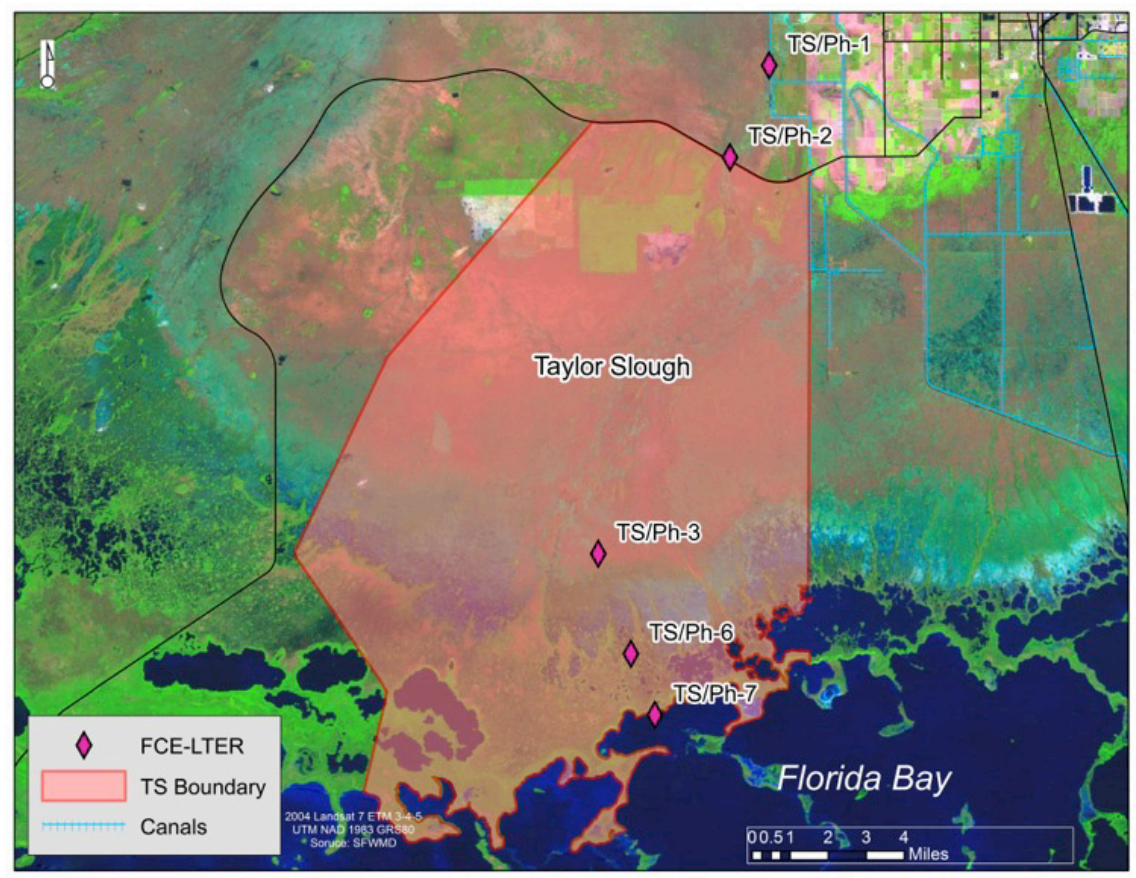

Figure 1.4. The FCE/LTER Taylor Slough sites used in this study. The freshwater sites are TS/Ph-1, TS/Ph-2, and TS/Ph-3. The coastal sites are TS/Ph-6 and TS/Ph-7.

The two FCE/LTER coastal sites, TS/Ph-6 and TS/Ph-7, are located in the EMER. The dominant vegetation at the coastal sites is dwarf red mangroves, though some freshwater emergent vegetation (predominantly sawgrass) intermixes with the mangroves. The FCE/LTER coastal sites are only accessible by powerboat. Sites TS/Ph-6 
and TS/Ph-7 have a boardwalk and a number of groundwater wells. Site TS/Ph-6 is located upstream of TS/Ph-7 with TS/Ph-7 located on the Buttonwood Ridge close to Taylor River; TS/Ph-7 also has a weather tower located at the western end of the boardwalk.

\section{CHAPTER 2}

\section{METHODS}

\section{WATER FLUSHING TIMES}

The system-wide water transport timescale, flushing time $\left(T_{f}\right)$ was measured using the formula:

$$
T_{f}=V / Q_{\text {Tout }}
$$

where, $V$ was volume and, $Q_{\text {Tout }}$ was total outflow. Flushing times were calculated on a monthly timescale for the long term study (2001-2011). Between January 2008 and July 2009, Equation 1 was calculated on a daily, weekly, bi-weekly, and monthly timescales using data by Zapata-Rios (2010) and compared on a monthly timescale to flushing time calculations using data obtained for this work. The $V$ was calculated as the product of water depth and area. For water depth, surface water level layers and a Digital Elevation Model (DEM) were created using Geographic Information Systems (GIS) Spatial Analysis tools using the EDEN stations and High Accuracy Elevation Dataset (HAED) respectively. The Everglades Depth Estimation Network (EDEN) is a monitoring network that provides continuous water-level data from 253 gaging stations operated by the Big Cypress National Preserve (BCNP), ENP, South Florida Water Management District (SFWMD), and United States Geological Survey (USGS). The EDEN hydrologic 
gauges were surveyed to the North American Vertical Datum of 1988 (NAVD 88). For the Taylor Slough study area, thirty-seven of the gaging stations located within the study area were used (Figure 2.1; Table 2) to obtain surface water level, precipitation (20022011), and evapotranspiration (2001-2010) data. Major vegetation and salinity (where available) data were also provided for each of the EDEN stations.

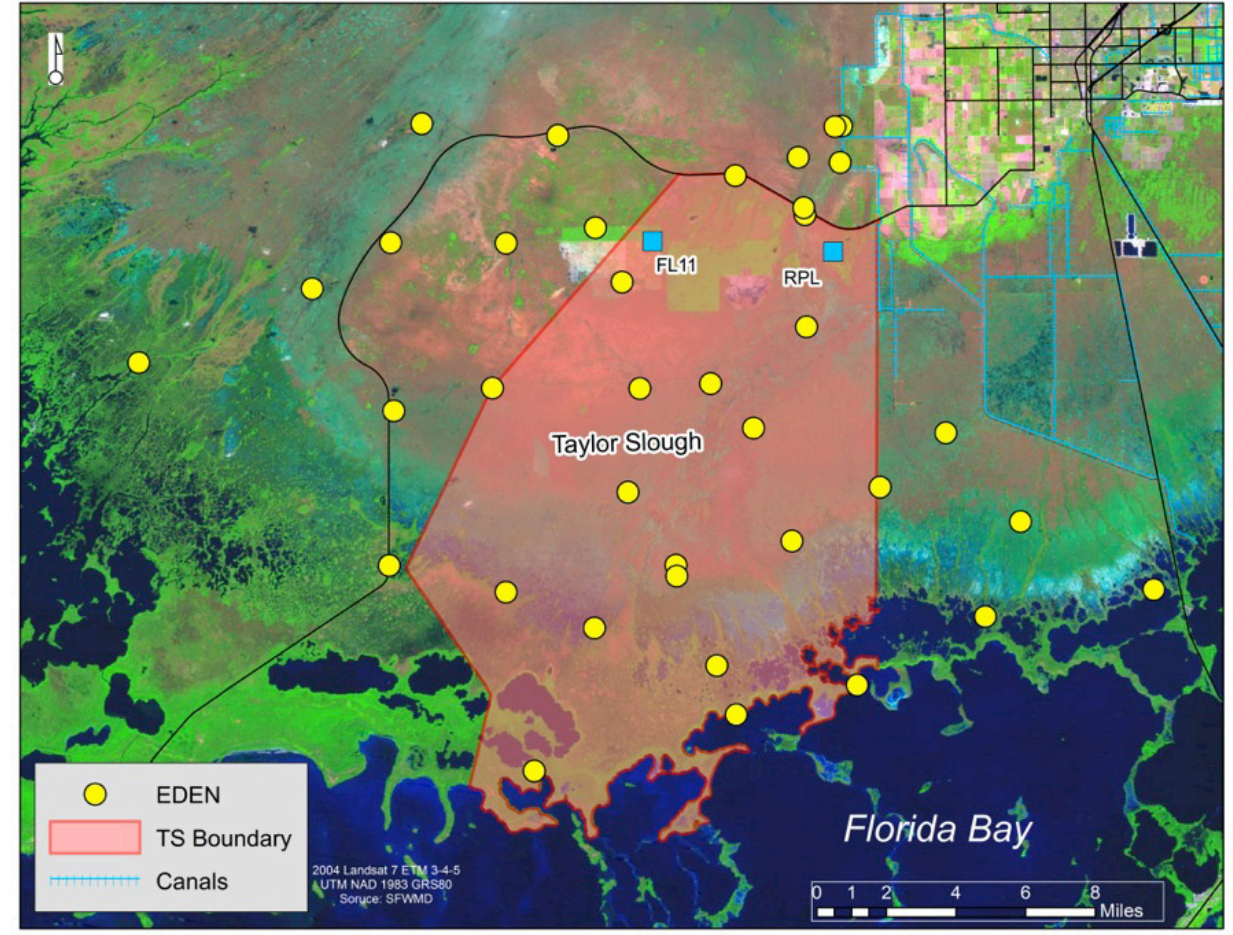

Figure 2.1. Southern Taylor Slough and the 37 EDEN gaging stations used in the study. The National Atmospheric Deposition Program site FL11 and Royal Palm Ranger Station (RPL) are also shown.

Daily water level data from the 37 EDEN stations were obtained from January 1, 2001 to January 1, 2012. Using the water level data for the first day of each month, a total of $133,400 \mathrm{~m} \times 400 \mathrm{~m}$ raster surfaces were created using the Spatial Analyst tool

Ordinary Kriging method (with Spherical Variogram model) in GIS (DYYMM01; $\mathrm{YY}=$ year, $\mathrm{MM}=$ month) (Figure 2.2, 2.3.A). A mask of the Taylor Slough area was 
applied to produce a raster grid covering only the area of interest. From January 1, 2008 to July $31,2009,578$ surface water level raster layers were created on a daily timescale.

Table 2: Thirty seven EDEN stations used to obtain data on surface water level, precipitation, and evapotranspiration in southern Taylor Slough.

\begin{tabular}{|c|c|c|c|c|c|}
\hline EDEN Station & Operating & & & & \\
\hline Name & Agency & Latitude & Longitude & UTM E & UTM N \\
\hline CP & ENP & 25.3275 & -80.703889 & 529818.81 & 2790185 \\
\hline CY2 & ENP & 25.3275 & -80.682778 & 531919.14 & 2801263 \\
\hline CY3 & ENP & 25.327778 & -80.750556 & 525097.66 & 2801279 \\
\hline DO1 & ENP & 25.371944 & -80.690833 & 531097.06 & 2806182 \\
\hline DO2 & ENP & 25.388333 & -80.744167 & 525727.88 & 2807986 \\
\hline E112 & ENP & 25.423889 & -80.609722 & 539240.69 & 2811956 \\
\hline E146 & ENP & 25.253611 & -80.666389 & 533588.89 & 2793085 \\
\hline EPSW & ENP & 25.271389 & -80.508056 & 549526.79 & 2795103 \\
\hline EVER7 & ENP & 25.308611 & -80.542222 & 546072.44 & 2799212 \\
\hline JB & USGS & 25.232625 & -80.524867 & 547898.05 & 2790716 \\
\hline L31W & ENP & 25.436944 & -80.589722 & 541247.55 & 2813407 \\
\hline MCC & USGS & 25.168194 & -80.733589 & 527034.02 & 2783566 \\
\hline $\mathrm{MC}$ & USGS & 25.203303 & -80.584111 & 541970.27 & 2787541 \\
\hline NCL & ENP & 25.239444 & -80.744444 & 525730.64 & 2791838 \\
\hline NRU & USGS & 25.338611 & -80.913056 & 508742.28 & 2802458 \\
\hline NP44 & ENP & 25.433333 & -80.720278 & 528120.54 & 2812974 \\
\hline NP46 & ENP & 25.318333 & -80.795833 & 520542.31 & 2800226 \\
\hline NP62 & ENP & 25.438333 & -80.782778 & 521834.87 & 2813516 \\
\hline NP67 & ENP & 25.329444 & -80.650278 & 535189.52 & 2801486 \\
\hline NP72 & ENP & 25.394722 & -80.703056 & 529861.83 & 2808702 \\
\hline NTS1 & ENP & 25.436667 & -80.592778 & 540940.39 & 2813376 \\
\hline NTS14 & ENP & 25.416389 & -80.638611 & 536337.73 & 2811117 \\
\hline $\mathrm{OL}$ & ENP & 25.263611 & -80.613056 & 538956.66 & 2794207 \\
\hline P37 & ENP & 25.284167 & -80.688333 & 531371.13 & 2796463 \\
\hline P38 & ENP & 25.369444 & -80.833333 & 516760.87 & 2805880 \\
\hline R127 & ENP & 25.353056 & -80.606111 & 539626.91 & 2804113 \\
\hline S332_T & SFWMD & 25.421944 & -80.590556 & 541180 & 2811722 \\
\hline SP & ENP & 25.388611 & -80.797222 & 520390.78 & 2808007 \\
\hline TR & USGS & 25.190594 & -80.639053 & 536376.84 & 2786172 \\
\hline TSW E146 & USGS & 25.252556 & -80.666261 & 533624.49 & 2792580 \\
\hline TRU & USGS & 25.210297 & -80.647667 & 535475.28 & 2788446 \\
\hline TS2 & ENP & 25.4 & -80.606667 & 539555.74 & 2809311 \\
\hline TSH & ENP & 25.310833 & -80.630556 & 537180.09 & 2799431 \\
\hline WHC & USGS & 25.242108 & -80.447572 & 555693.23 & 2791958 \\
\hline TSB & ENP & 25.402972 & -80.607306 & 539496.66 & 2809628 \\
\hline EVER5A & USGS & 25.286111 & -80.572556 & 543033.1 & 2796698 \\
\hline NMP & ENP & 25.25385 & -80.79813 & 520329 & 2793072 \\
\hline
\end{tabular}




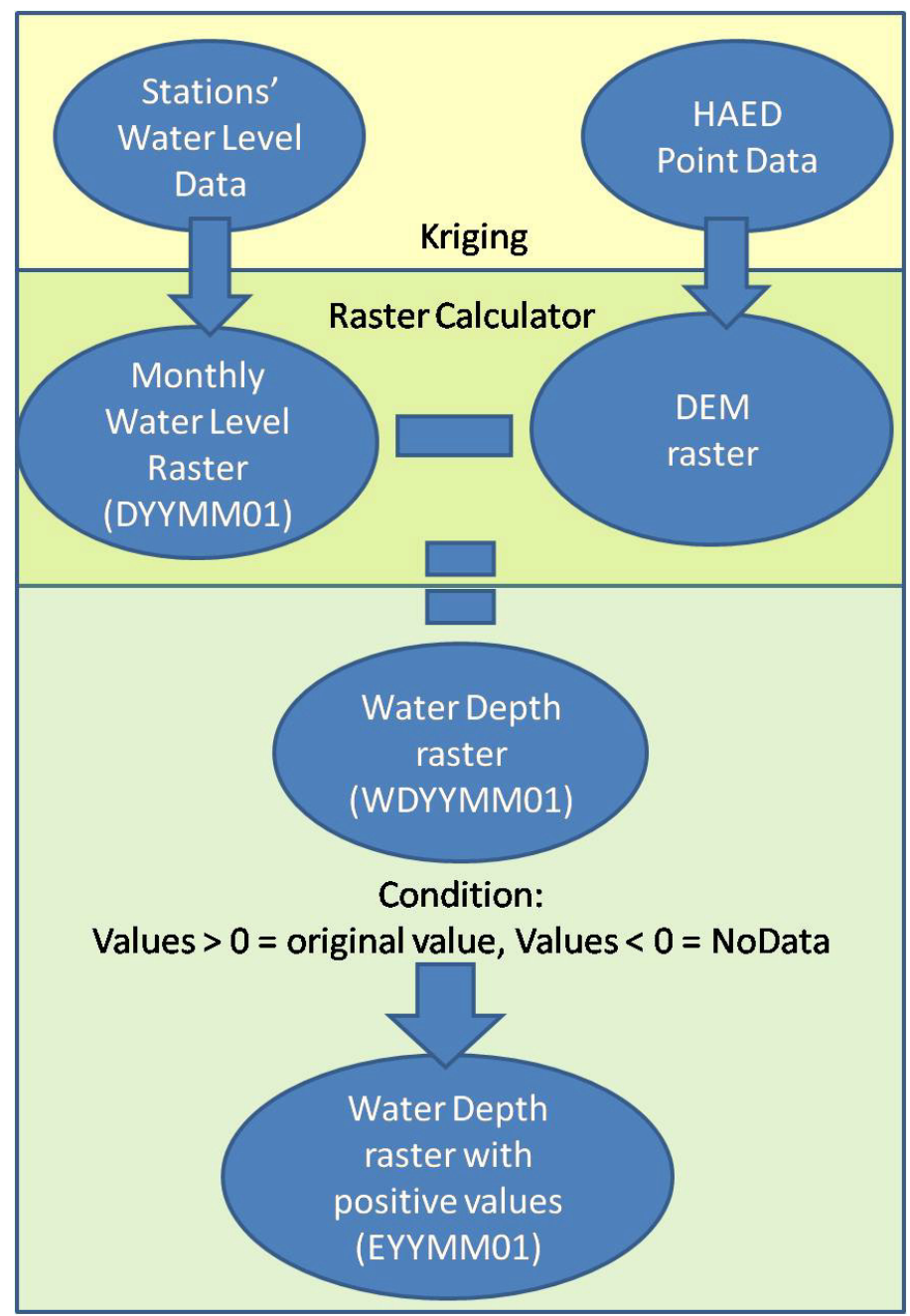

Figure 2.2. Flow chart of GIS processes to obtain water depth raster (WDYYMM01) and rasters (EYYMM01) used for Volume (V) of the flushing time calculation.

The HAED data were collected in the High Accuracy Elevation Data Project from 1995 to 2007 by the USGS for the Everglades area used in the EDEN program (Figure 2.4). Elevation data points were collected (in meters) every 400 meters with a vertical accuracy of $\pm 15 \mathrm{~cm}$ as referenced to horizontal datum North American Datum 1983 (NAD83) and vertical datum NAVD88. Surveying was done using truck, airboat, and helicopter using GPS technology. For the helicopter, the USGS developed the Airborne Height Finder (AHF), which measured the surface elevation using an airborne GPS 
platform and high-tech version of the surveyor's plumb bob. The AHF was able to penetrate vegetation and water to give accurate topographic surface measurements. Tests performed by the USGS showed the AHF consistently measured elevation points at the subdecimal level (Desmond, factsheet 2003). Using the HAED data, a 400m x 400m DEM was created using the Spatial Analyst tool Ordinary Kriging method in GIS (Figures 2.2, 2.5). Creating a DEM was used as opposed to using DEMs made available by the USGS, EDEN, and SFWMD due to lack of data in the available DEMs of the coastal mangrove areas of Taylor Slough.

In GIS, the surface water level raster layers were then subtracted by the DEM to create a water depth layer (WDYYMM01) for each month (Figures 2.2, 2.3.B) from January 2001 to December 2011 except for the period from January 1, 2008 to July 31, 2009, when the water depth layers were created on a daily basis. A Raster Calculator Conditional command was used to eliminate values less than zero in the WDYYMM01 layer to create a total of 711 raster layers, Eyymmdd (Figure 2.2.C), which contained only grids with values greater than zero. Zonal Statistics in GIS gave the raster layer's count, area, minimum, maximum, range, mean, standard deviation, and sum. The resultant value of $V$ was obtained by multiplying the Eyymmdd layer's area with its mean.

To obtain $Q_{\text {Tout }}$, a water budget equation for the Taylor basin developed by Zapata-Rios and Price (2012) was used:

$$
P+Q_{\text {in }}-E T \pm Q_{\text {out }} \pm G W \pm R=S
$$

where, $P$ was precipitation, $Q_{\text {in }}$ was surface water inflow to system, $E T$ was evapotranspiration, $Q_{\text {out }}$ was surface water outflow, $S$ was change in storage, GW was 
groundwater/surface water exchange, and $R$ was a residual which was any error associated with each of the terms. The term $Q_{\text {Tout }}$ was determined as the sum of the outputs from Taylor Slough:

$$
Q_{\text {Tout }}=E T+Q_{\text {out }}+G W
$$



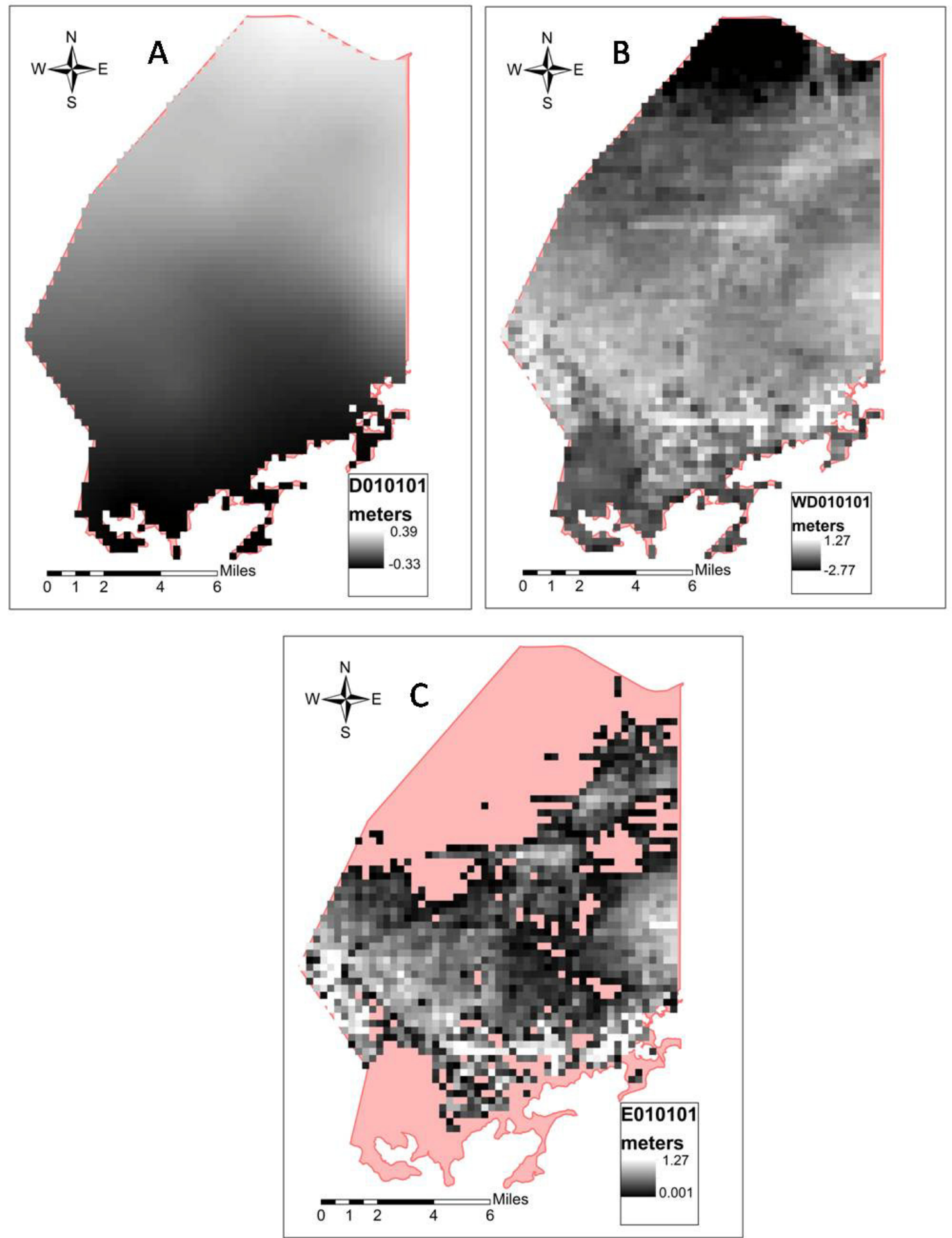

Figure 2.3. Rasters of Taylor Slough (A)Surface water level (meters), (B) water depth (meters), and (C) water depth raster with only grids containing values greater than zero (meters). The red outline and shading labels the area of southern Taylor Slough. 


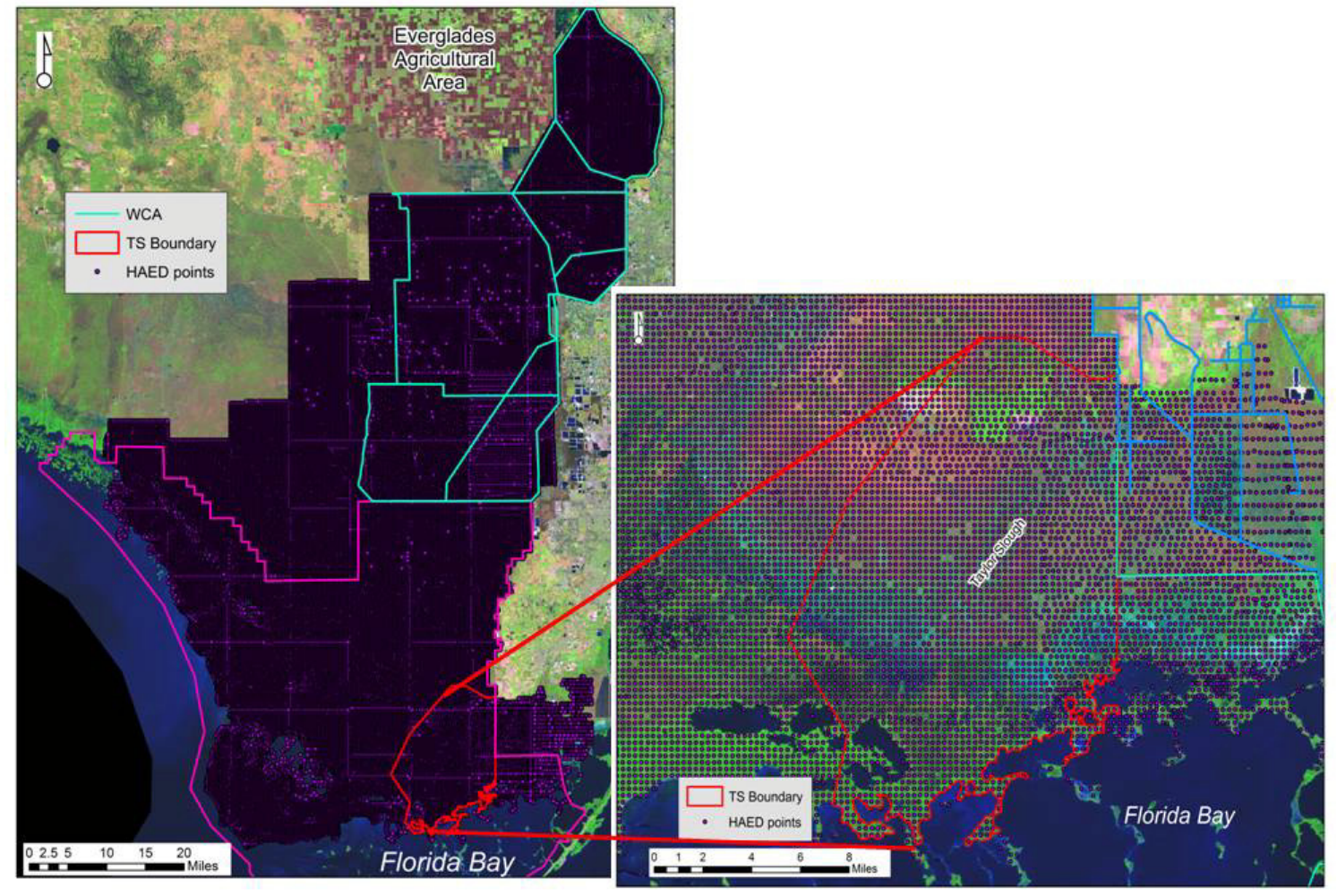

Figure 2.4. The overall extent of the HAED Project in the Everglades and a close-up of southern Taylor Slough study area.

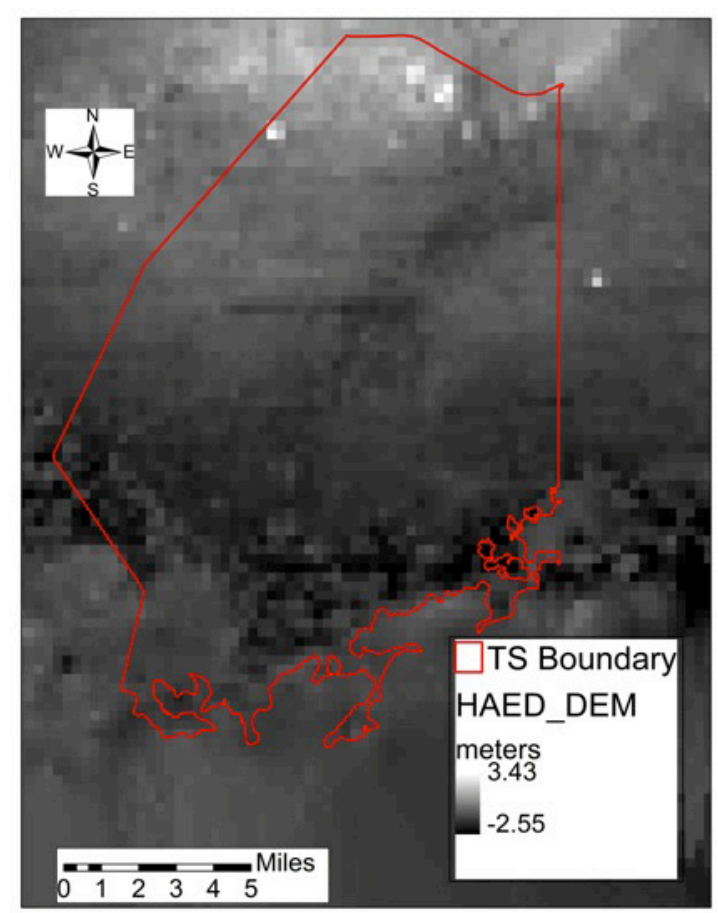

Figure 2.5. DEM created using the HAED data (meters). 
Precipitation (P)

Precipitation data was obtained from the EDEN stations from January 1, 2002 to December 31, 2011. The distributed EDEN rainfall data from the SFWMD were generated by Next Generation Radar (NEXRAD) or Weather Surveillance Radar 88 Doppler (WSR-88D) data from the U.S. National Weather Service, which provided complete spatial coverage of rainfall using a $2 \mathrm{~km} \times 2 \mathrm{~km}$ grid resolution. OneRain, Inc. (January 2002 - October 2007) and Vieux Inc. (November 2007 - present) processed the NEXRAD data for the SFWMD. The NEXRAD rainfall data were in continuous "near real-time" 15-minute interval and adjusted using gauge data algorithms. Rain gauge data were obtained by One Rain, Inc. and Vieux Inc. from approximately 152 telemetered rain gauge sites that also give rainfall accumulation data in 15 -minute intervals. The gauge adjusted radar rainfall data are then sent to the South Florida Water Management District. The gauge-adjusted radar has a precision reported to the nearest $1 / 100^{\text {th }}$ of an inch. The near real-time 15-minute interval data are then verified each month and an end-of-month (EOM) file is created and sent to the South Florida Water Management District. The quality-assured EOM data uses an additional 81 rain gauge station data to adjust the radar rainfall values using a proprietary algorithm that follows the Brandes method. The Everglades Depth Estimation Network receives the EOM data for the EDEN grid cells from the South Florida Water Management District. The EOM data is used to obtain daily gauge-adjusted rainfall values (in inches) for each the EDEN stations and made available on the EDEN website.

Using the EDEN files, daily rainfall values for each of the 37 stations in the Taylor Slough region were converted to meters and summed per month then exported to 
GIS for analysis. In GIS, the point file was used to create a total of 132 Thiessen Polygon layers (Figure 2.6A), which were then converted to a raster (Figure 2.6.B) for a total of 132 rasters. The layers were once again masked to just give data for the Taylor Slough area. For 2001, daily rainfall data were obtained from 10 stations (Table 2) managed by ENP, SFWMD, and National Oceanic and Atmospheric Administration (NOAA). The same procedures to create raster layers on GIS used for the EDEN stations were used for the 2001 data (Figure 2.7). Precipitation data was given a 10\% error (Price et al., 2007).
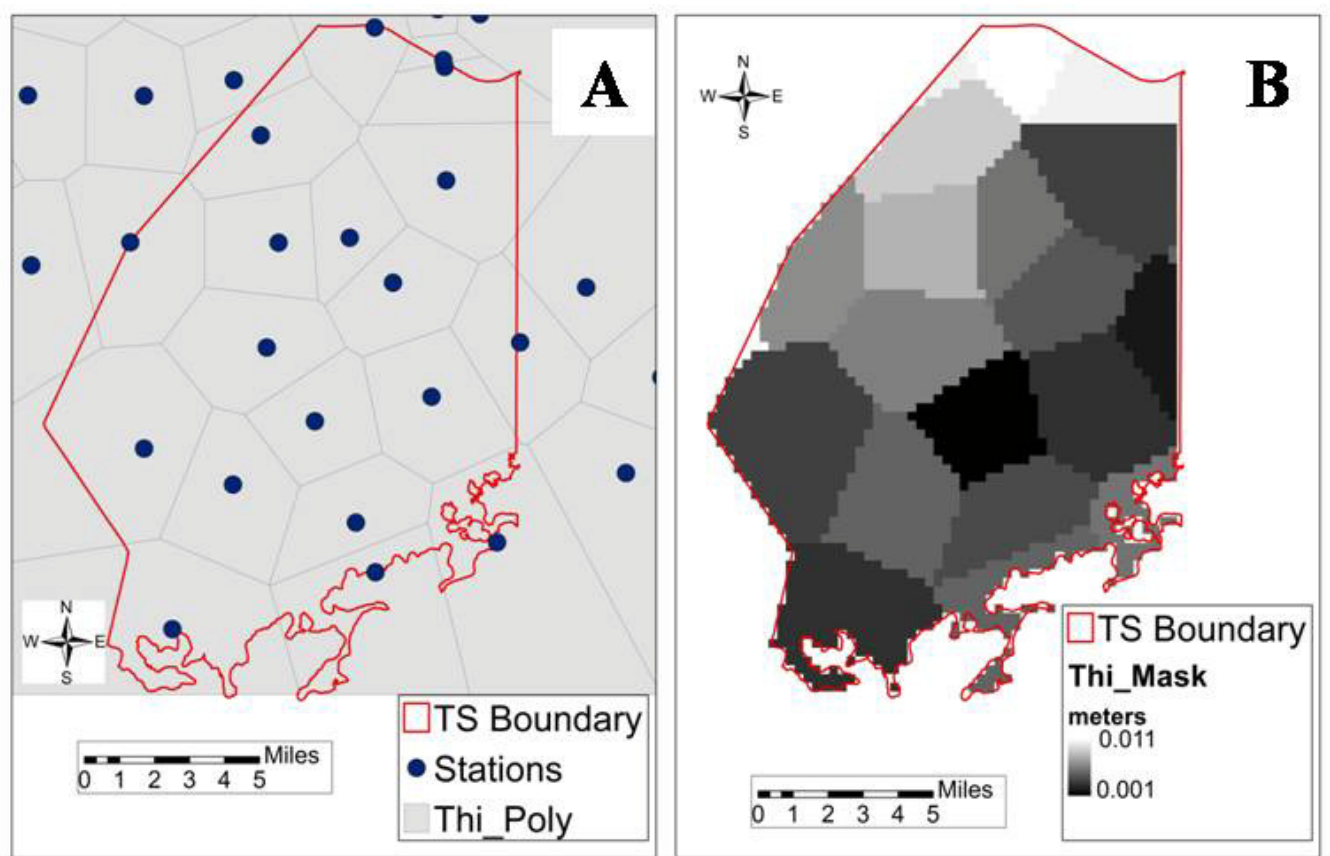

Figure 2.6. (A) Thiessen Polygon of southern Taylor Slough using the 37 EDEN stations for $2002-2011$ and the (B) rasterized version of the Thiessen Polygon. 
Table 3. Stations used to obtain precipitation data of southern Taylor Slough for 2001.

\begin{tabular}{|llllll|}
\hline EDEN & $\begin{array}{c}\text { Operating } \\
\text { Station Name Agency }\end{array}$ & Latitude & Longitude & UTM E & UTM N \\
\hline CP & ENP & 25.3275 & -80.703889 & 529818.81 & 2790185 \\
CY3 & ENP & 25.327778 & -80.750556 & 525097.66 & 2801279 \\
EPSW & ENP & 25.271389 & -80.508056 & 549526.79 & 2795103 \\
P37 & ENP & 25.284167 & -80.688333 & 531371.13 & 2796463 \\
P38 & ENP & 25.369444 & -80.833333 & 516760.87 & 2805880 \\
R127 & ENP & 25.353056 & -80.606111 & 539626.91 & 2804113 \\
TSB & ENP & 25.402972 & -80.607306 & 539496.66 & 2809628 \\
RPL & ENP & & & 540852 & 2789893 \\
JBTS & SFWMD & 25.25385 & -80.79813 & 520329 & 2793072 \\
083020-3 & NOAA & 25.1422222 & -80.914444 & 508623 & 2780698 \\
\hline
\end{tabular}
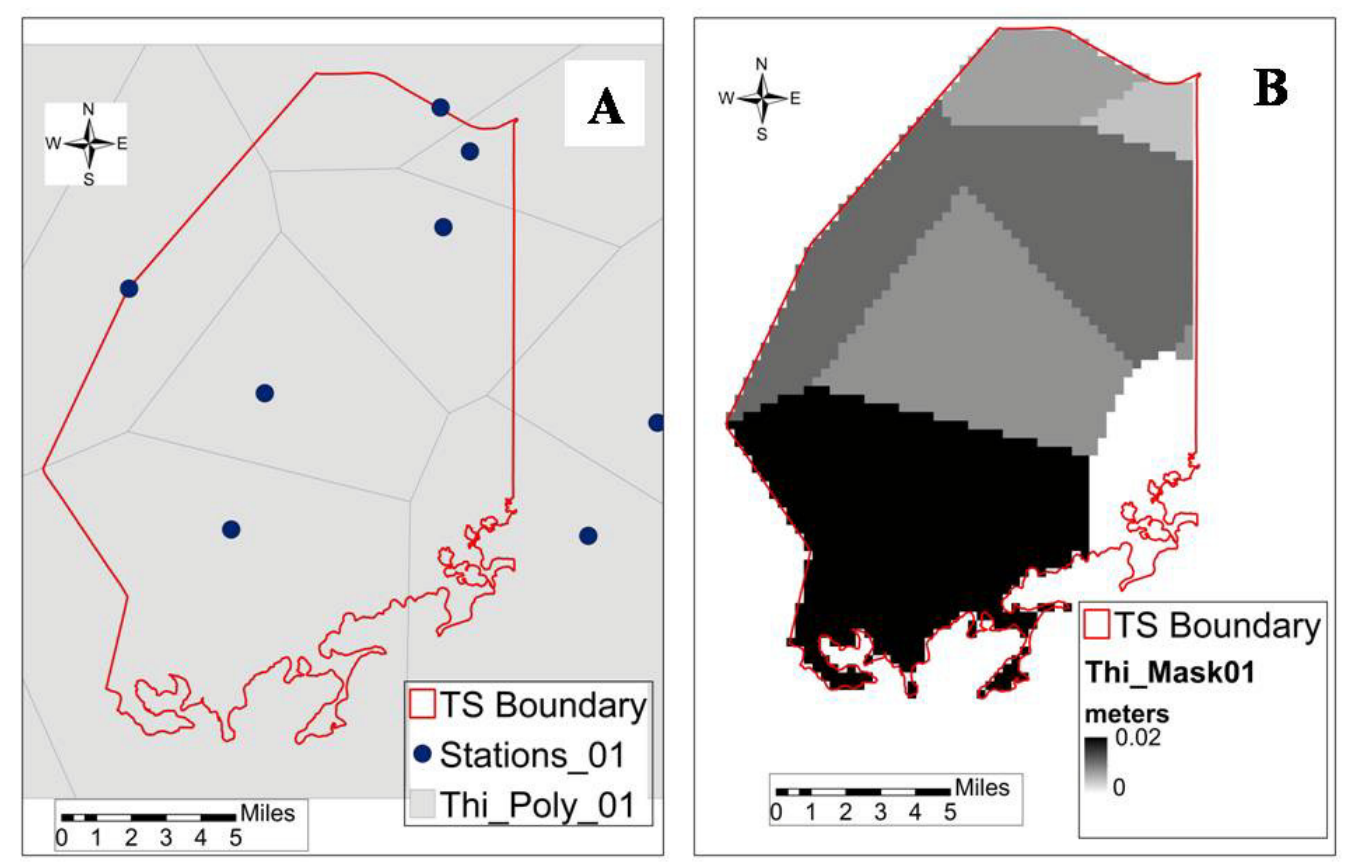

Figure 2.7. (A) Thiessen Polygon of southern Taylor Slough using 10 stations from ENP, SFWMD, and NOAA for 2001 and the (B) rasterized version of the Thiessen Polygon.

Surface Water Inflow $\left(Q_{i n}\right)$ and Outflow $\left(Q_{o u t}\right)$

Daily $Q_{\text {in }}$ data to Taylor Slough was obtained from the TSB site from Everglades National Park. The collection points included 23 culverts/bridges by the Main Park Road 
that discharge into Taylor Slough. The daily $Q_{i n}$ data were summed up per month to obtain a monthly total. The TSB inflow data were compared to data obtained from ENP for the pump stations S332D, S332B, S332B2, and S332C. Daily $Q_{\text {out }}$ data from the three coastal stations McCormick Creek (MCC), Taylor River (TR), and Mud Creek (MC) were obtained from the USGS (http://waterdata.usgs.gov/fl/nwis/rt). The $Q_{\text {out }}$ data for all three stations were summed to obtain a monthly total. Net overflow of the Buttonwood Embankment was approximately 1.5 percent of creek discharge (Langevin et al. 2004) during storm surge events and was considered negligible to Qout. An error of $9.1 \times 10^{5}$ $\mathrm{m}^{3} /$ month was assumed for the surface water inflow and outflow data (personal communication with Mark Zucker).

Evapotranspiration (ET)

The USGS calculated daily PET values for each of the EDEN stations using the Priestley-Taylor (PT) method. To calculate the net radiation values needed for the PT method, incoming solar radiation (insolation) estimates using NOAA's Geostationary Operational Environmental Satellite (GOES) "East" were obtained. The satellite estimates were made using the Gautier-Diak-Masse (GDM) insolation model. The data were produced in half hourly daily temporal resolution at a $2 \mathrm{~km}$ horizontal spatial resolution (Jacobs et al., 2008). The GOES insolation estimates were compared to ground based pyranometers, located at weather stations across Florida, as calibration. The weather stations were managed by the State of Florida Water Management District, St. John's River Water Management District (SJRWMD), SFWMD, University of Florida Institute of Food and Agricultural Sciences (UF IFAS), Florida Automated Weather 
Network (FAWN), and USGS agency. Calculated PET values have an approximate error of $10 \%$ error (Mecikalski et a., 2011).

The daily ET data obtained from 37 EDEN stations in the Taylor Slough study area were summed to obtain a monthly total per station and converted to meters. The data were then joined to the station point layer in GIS. Using the Spatial Analyst Ordinary Kriging method, a total of 132 raster layers were created on a monthly scale (Figure 2.8). The layers were masked to the Taylor Slough area.

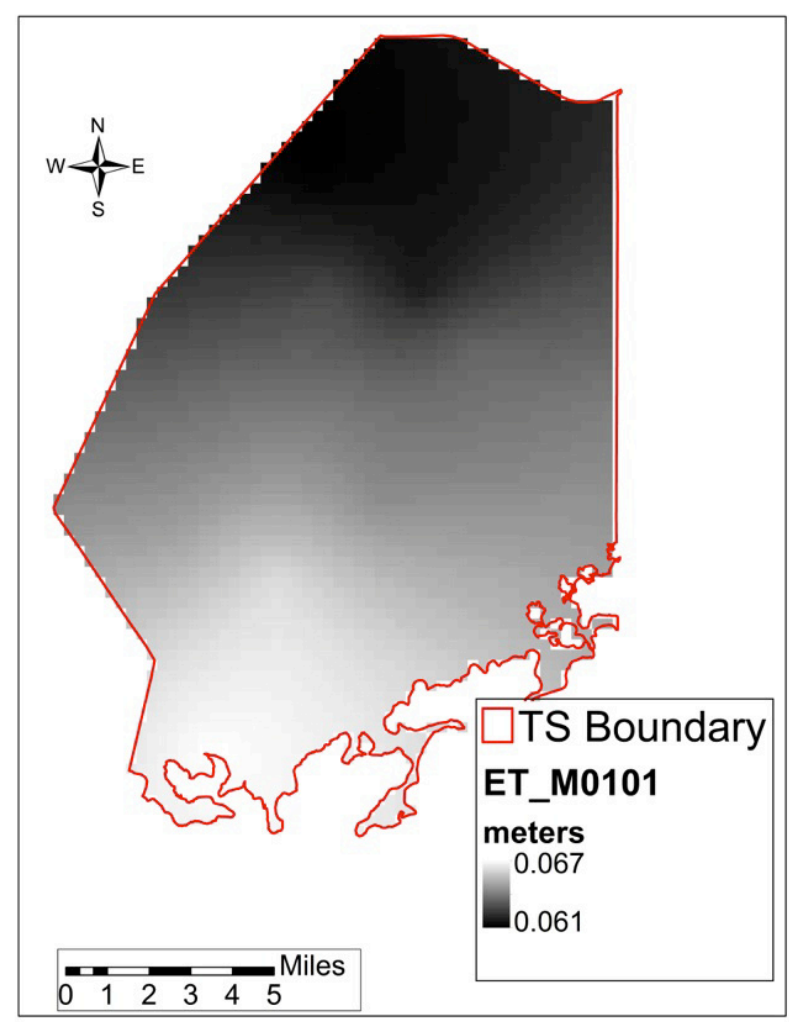

Figure 2.8. Raster layer of ET created using Spatial Analyst Kriging tool. 
Change in Storage $(S)$ and Groundwater $(G W)$

The change in storage $(S)$ was obtained as the difference between the monthly WDYYMM01 raster grids (Figure 2.9) created in GIS. First, a Conditional command using Raster Calculator was performed to create a total of 132 rasters (Con_WDYYMM01) containing only values greater than zero (Figures 2.9, 2.10) with values of less than zero given a zero value. Rasters created to use for volume (EYYMM01) in the flushing time calculations had varying area values as values less than zero were given a NoData value and were eliminated from the grid (Figure 2.3C) while the Con_WDYYMM01(Figure 2.10) rasters had a constant area. Conditional water depth raster of the proceeding month was then subtracted by the current month's

Con_WDYYMM01 raster to obtain the current month's change in storage raster (SConYY_MM). Zonal Statistics for each SConYY_MM raster were produced and using Microsoft Excel, the mean value was multiplied by the study area $\left(446 \times 10^{6} \mathrm{~m}^{2}\right)$ to obtain S of the basin. Water level data of the EDEN stations have an estimated 4\% error (Conrads, 06) which was used for the $\mathrm{S}$ error. Groundwater $(\mathrm{GW})$ was calculated as the remainder from the water budget equation, once all the preceding variables were input into the monthly time-scale equation. A positive $G W$ indicated that groundwater was discharging to the surface water, while a negative $G W$ indicated surface water was recharging the groundwater.

Precipitation Ratios

Relationships between $P, Q_{i n}, Q_{o u t}$, and $S$ were made in order to discern between climate versus restoration effects on the hydrologic parameters of southern Taylor 
Slough. An increase in the relative ratios of $Q_{i n} / P, Q_{\text {out }} / P$, and $S / P$ would be expected as a result of increased flows to southern Taylor Slough in response to restoration efforts. A decrease in the relative ratios would signal a precipitation effect as opposed to a restoration effort effect.

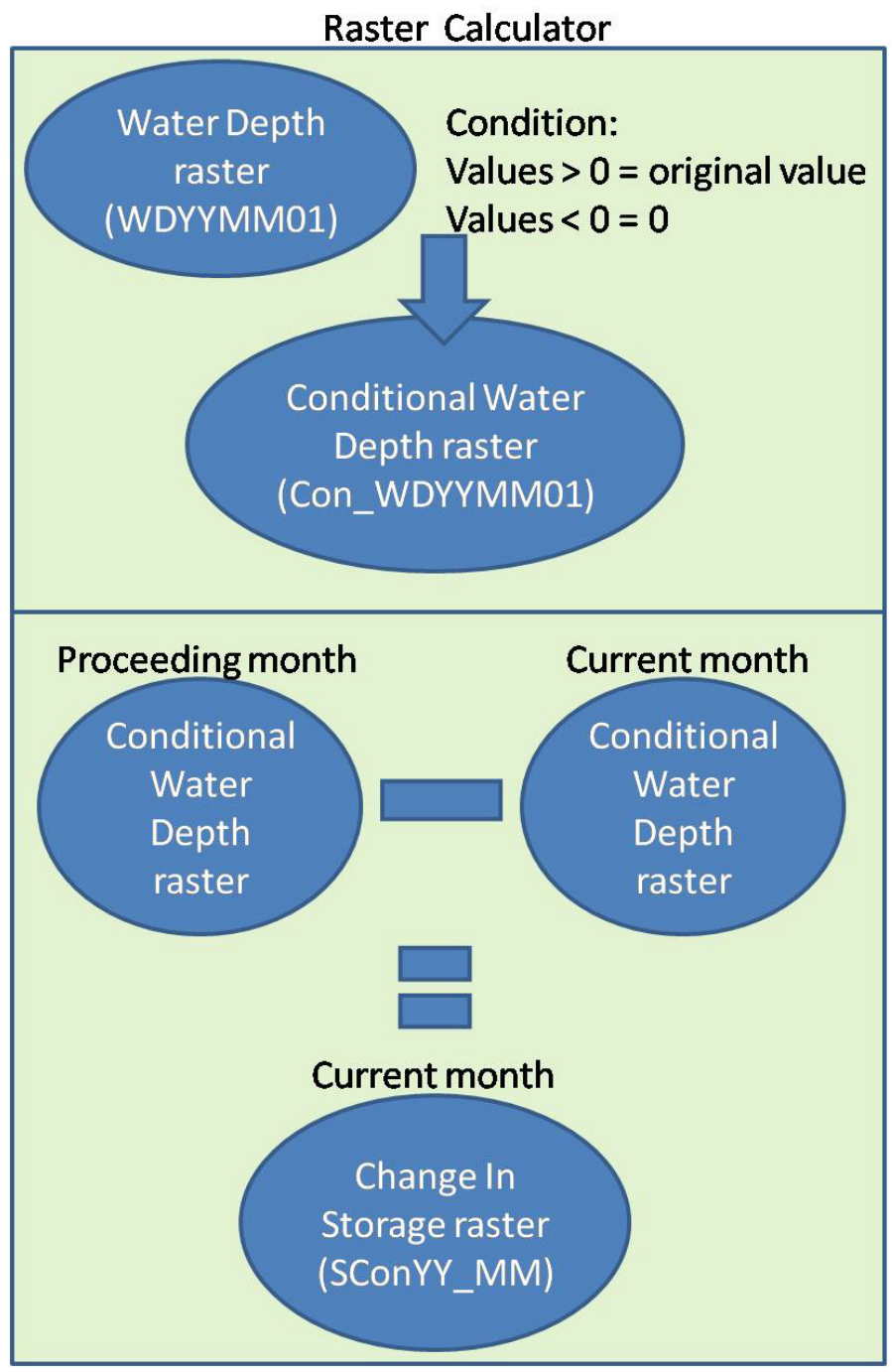

Figure 2.9. Flow chart of raster processes to obtain change in storage (S) rasters 


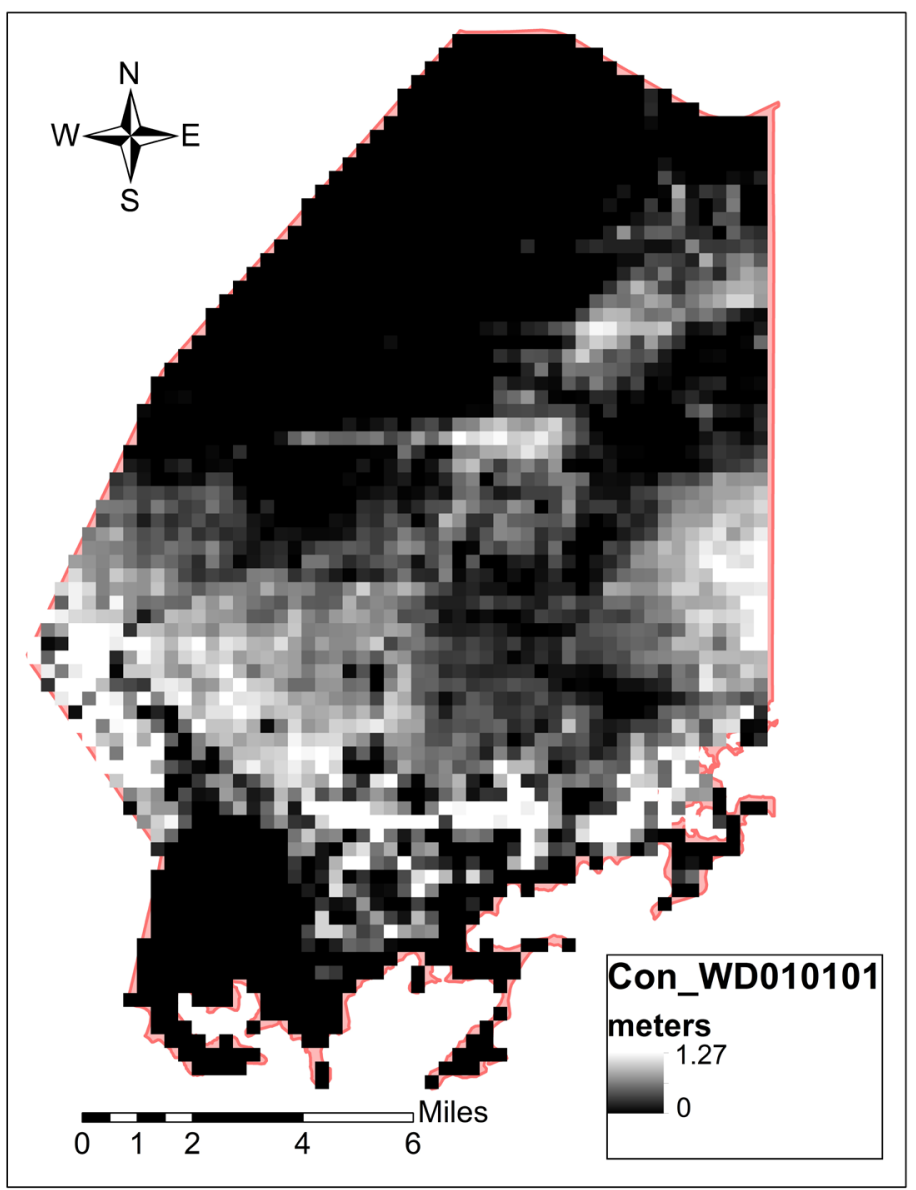

Figure 2.10. GIS raster layer of water depth layer used to obtain change in storage where the condition command of values less than zero were given zero values.

\section{CHEMICAL ANALYSIS}

Water Chemistry

Ground and surface water samples were analyzed for major anions (chloride and sulfate) and cations (potassium, sodium, magnesium and calcium) using a Dionex model DX-120 Ion Chromatograph in FIU's Hydrogeology Laboratory. Groundwater samples 
spanned from November 2011 through July 2012 while surface water samples spanned from August 2008 to July 2012. Samples were a combination from field campaigns and FCE-LTER stations. Chemistry data for $2001-2008$ were obtained from historical databases (Gaiser et al. 2010) or literature references (Price 2001). Nutrient analysis focused on total phosphorus (TP) and total nitrogen (TN). The water chemistry data were compared, analyzed, and correlated with the water flushing time values.

Field campaigns were performed to collect groundwater and surface water samples at the sites: TSB (2011 - 2012); TS/Ph-3 (2012); TS/Ph-6 (2010 - 2012); and TS/Ph-7 (2010 - 2012). The wells at TSB (depth: $4.57 \mathrm{~m})$ and TS/Ph-3 (depth: $3.05 \mathrm{~m}$ ) were first purged of three well volumes using a high volume pump for five minutes. A peristaltic pump was then used to collect a total of five samples; two samples were unfiltered while the remaining three samples were filtered through a $0.45 \mu \mathrm{m}$ filter. During the field campaigns temperature, conductivity, and salinity values were recorded for surface water and groundwater using an YSI Model 85 conductivity, salinity, temperature, and oxygen meter. Surface water and groundwater $\mathrm{pH}$ values were also recorded using a Thermo Scientific Orion $3 \mathrm{Star} \mathrm{pH}$ meter and probe. Total alkalinity was determined by acid titration using a Brinkman Titrino 751 Titrator with $0.01 \mathrm{~N}$ concentration of $\mathrm{HCl}$ to a $\mathrm{pH}$ of 2 . Total alkalinity was calculated from the $\mathrm{mL}$ of acid added at the inflection point closest to a $\mathrm{pH}$ of 2 . Change in volume of the sample as a result of the addition of the titrant was not considered because of the small volume added. Total alkalinity was calculated as meq $\mathrm{L}^{-1}$ as $\mathrm{HCO}_{3}{ }^{-}$as the $\mathrm{pH}$ of the water samples was near neutral. 
An ISCO Sampler, located at the FCE/LTER sites, collected 1 L surface water samples that represented a three-day composite of $250 \mathrm{~mL}$ of surface water collected every eighteen hours. Every month, the samples in the ISCO Sampler were retrieved. At that time, a surface water sample was also collected by hand by rinsing three times and then filling a $1000 \mathrm{~mL}$ plastic bottle from just below the surface of the water. Of the 1000 $\mathrm{mL}$ surface water samples collected by the ISCO Sampler and monthly grab samples, 120 $\mathrm{mL}$ was processed at the FIU Hydrogeology Laboratory for water chemistry analysis. The remaining portion of the water samples collected by the ISCO Sampler and the grab samples were analyzed at the Southeast Environmental Research Center (SERC) Nutrient Laboratory for TP, TN, and salinity.

The unfiltered field campaign samples were acidified with $10 \% \mathrm{HCl}$ and processed by the SERC Nutrient Laboratory at FIU for Total Nitrogen and Total Phosphorus. Of the filtered field campaign samples, one was acidified with $10 \% \mathrm{HCl}$ for cation analysis. The second filtered field campaign sample was analyzed for major anions and total alkalinity. The third filtered field campaign sample was sent to the SERC Soil/Sediment Biogeochemistry Laboratory. The ISCO sampler and monthly grab samples given to the FIU Hydrogeology Laboratory were each filtered through a $0.45 \mu \mathrm{m}$ filter into two separate bottles that were either $30-\mathrm{mL}$ or $60-\mathrm{mL}$; one bottle was acidified using $10 \% \mathrm{HCl}$ for major cation analysis while the other sample was not acidified and analyzed for major anions. A portion of the hand-collected sample given to the FIU Nutrient Laboratory was also filtered through a Whatman GF/F filter and analyzed for the dissolved inorganic nutrients nitrate, nitrite, ammonium, and phosphate. All nutrient data 
was made available from the FCE-LTER website as part of their Signature Datasets (http://www.fcelter.fiu.edu/data/FCE/signature-datasets.htm).

Stable Isotopes of oxygen and hydrogen

The stable isotopic compositions of oxygen $\left(\delta^{18} \mathrm{O}\right)$ and hydrogen $(\delta \mathrm{D})$ were determined only on the freshwater samples collected from Taylor Slough. Samples used for stable isotope analysis included filtered groundwater and surface water samples from the field campaigns from sites TSB and TS/Ph-3, surface water samples from the FCELTER monthly grabs during the field campaigns to the Taylor Slough sites, and rainfall samples from FIU rain collector. The rain collector is an Aerochemetrics wet/dry collector located on the roof of the Academic Health Center 2 building located on the FIU Modesto Maidique Campus. All the samples were analyzed for the stable isotopes of oxygen and hydrogen at FIU's Hydrogeology Laboratory using a Los Gatos Laser Instrument. The isotope data were used to support the dominant inputs of water into Taylor Slough as identified by equation 2 .

\section{FLUX OF IONS}

The sources of major ions to Taylor Slough have included $Q_{i n}, P$, and $R$. The proportion of each of the inputs was determined through the collection of both physical and chemical data. The physical inputs were determined by the solution of equation 2 , the water budget equation. The monthly physical inputs of rainfall, groundwater, and surface water were multiplied by the ion concentrations of chloride and calcium to obtain the ion flux. The chemical inputs for $P$ over the last decade were obtained from the National Atmospheric Deposition (NADP) National Trends Network (NTN) database for 
site F11 located in ENP. For $R$, groundwater ion concentration data from TS/Ph-3 and TSB were used and multiplied with the physical data obtained from the water budget equation (Eq.2). For $Q_{i n}$, chemical data from TS/Ph-2 were used and multiplied with the $Q_{\text {in }}$ physical data. Available data limited the ion flux calculations to 2009 and 2011.

\section{CHAPTER 3}

\section{RESULTS}

\section{WATER FLUSHING TIMES}

The daily $\mathrm{T}_{\mathrm{f}}$, calculated between January 1, 2008 and July 31, 2009 were highly variable, ranging from 1 - 762 days during this time period, with the shortest value occurring on May 18, 2009 and longest on August 18, 2008 (Figure 3.1). The weekly $\mathrm{T}_{\mathrm{f}}$ scale showed similar seasonal variability to the daily $\mathrm{T}_{\mathrm{f}}$ scale, having the highest variability between July 2008 and late January 2009. The average $\mathrm{T}_{\mathrm{f}}$ on a weekly time scale varied from 2 - 146 days during the time period, with the shortest value occurring the week of April 25, 2009 and longest on the week of August 17, 2008. The bi-weekly time scale showed the highest variability between August 2008 and November 2008. On a bi-weekly time scale, $\mathrm{T}_{\mathrm{f}}$ had values ranging from $3-84$ days with the shortest value occurring the week of May 16, 2009 and the longest on the week of August 31, 2008. On a monthly time scale, $\mathrm{T}_{\mathrm{f}}$ had values ranging between 6 - 56 days. In the monthly time scale, the shortest value occurred in April 2009 and the longest on September 2008. 


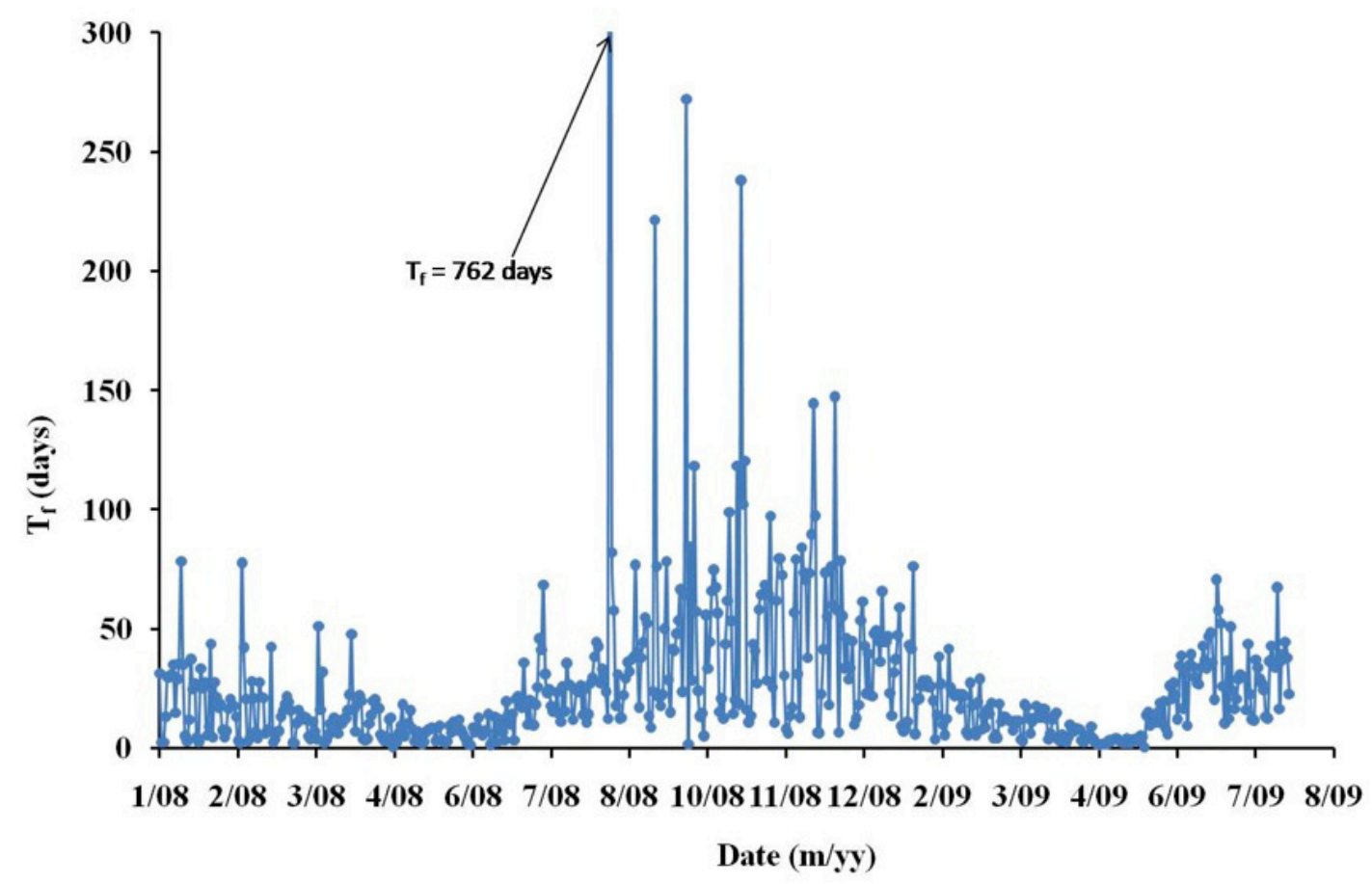

Figure 3.1. Daily water flushing times for southern Taylor Slough from January 1, 2008 to July 31, 2009.

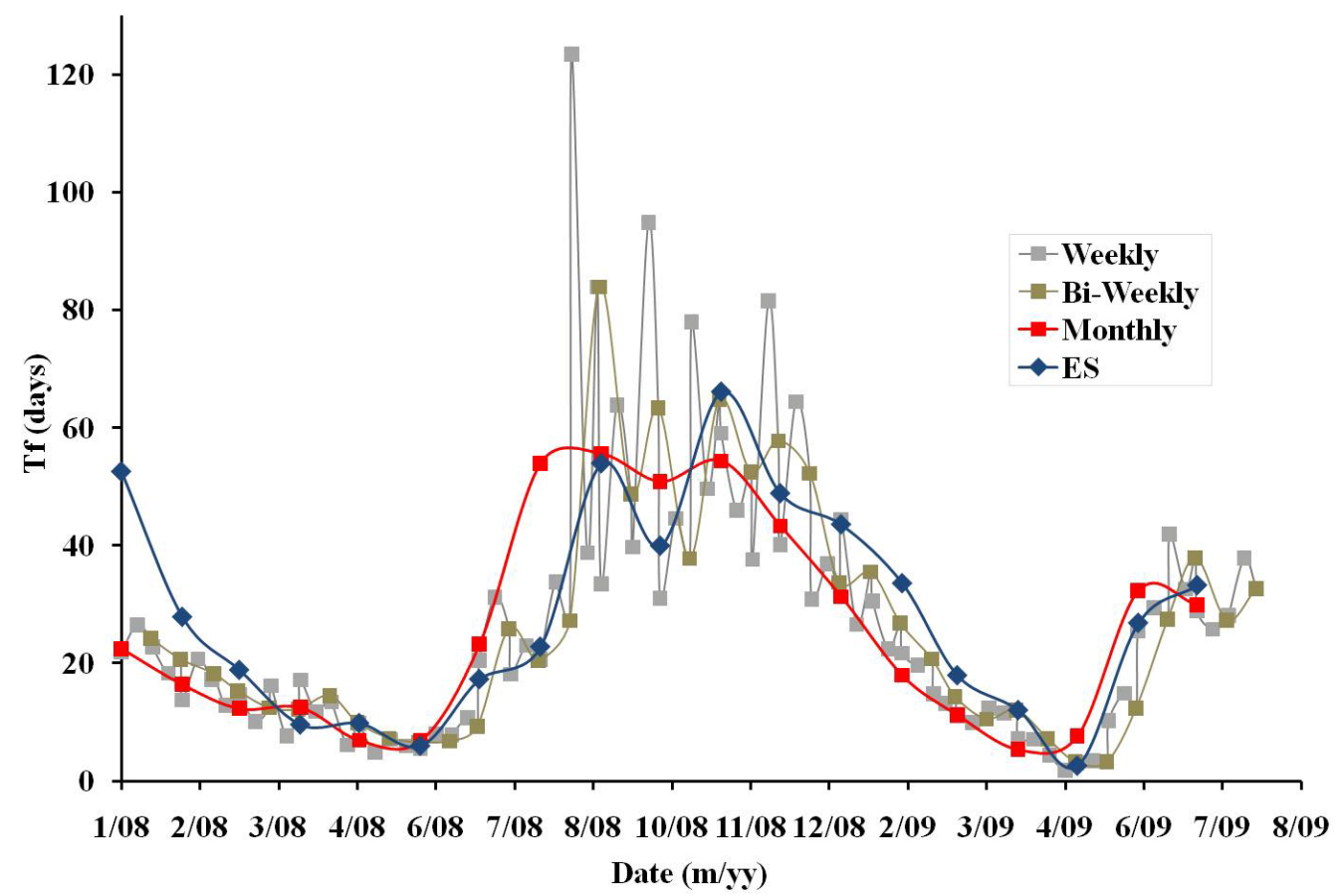

Figure 3.2. Water flushing times for weekly, bi-weekly, and monthly time-scales for January 1, 2008 - July 31, 2009. Monthly time-scale flushing times using data collected for this study is depicted in navy blue (ES). 
From January 2001 through December 2011, $\mathrm{T}_{\mathrm{f}}$ varied seasonally with a peak average flushing time of 59 days occurring in December and a minimum average flushing time of 11 days in May (Figure 3.3). The longest flushing time of 78 days occurred in November 2008while the shortest flushing time of 3 days occurred in May 2009 (Figure 3.4). Yearly average $T_{f}$ showed an increase after 2001, with 2010 having the highest yearly average of 40 days (Figure 3.5).

\section{VOLUME}

Monthly average volume (V) data had the highest average in the month of October with an average for the ten year study of $14.63 \times 10^{7} \mathrm{~m}^{3} /$ month and the lowest monthly average in May with an average value of $2.98 \times 10^{7} \mathrm{~m}^{3} /$ month (Figure 3.6). During the ten year study period, the month with the highest observed volume was September $2005\left(1.87 \times 10^{8} \mathrm{~m}^{3} /\right.$ month $)$ while the month with the lowest observed volume was May $2009\left(8.18 \times 10^{6} \mathrm{~m}^{3} /\right.$ month) (Figure 3.7). The year with the highest total sum of volume was 2003 with a sum of $1.09 \times 10^{9} \mathrm{~m}^{3} /$ year, while the year with the lowest total sum was 2001 with a total sum of $7.45 \times 10^{8} \mathrm{~m}^{3} /$ year (Figure 3.8). Volume had an R-squared relationship with flushing times of $0.438(\mathrm{P}<<0.05)$ (Figure 3.9). 


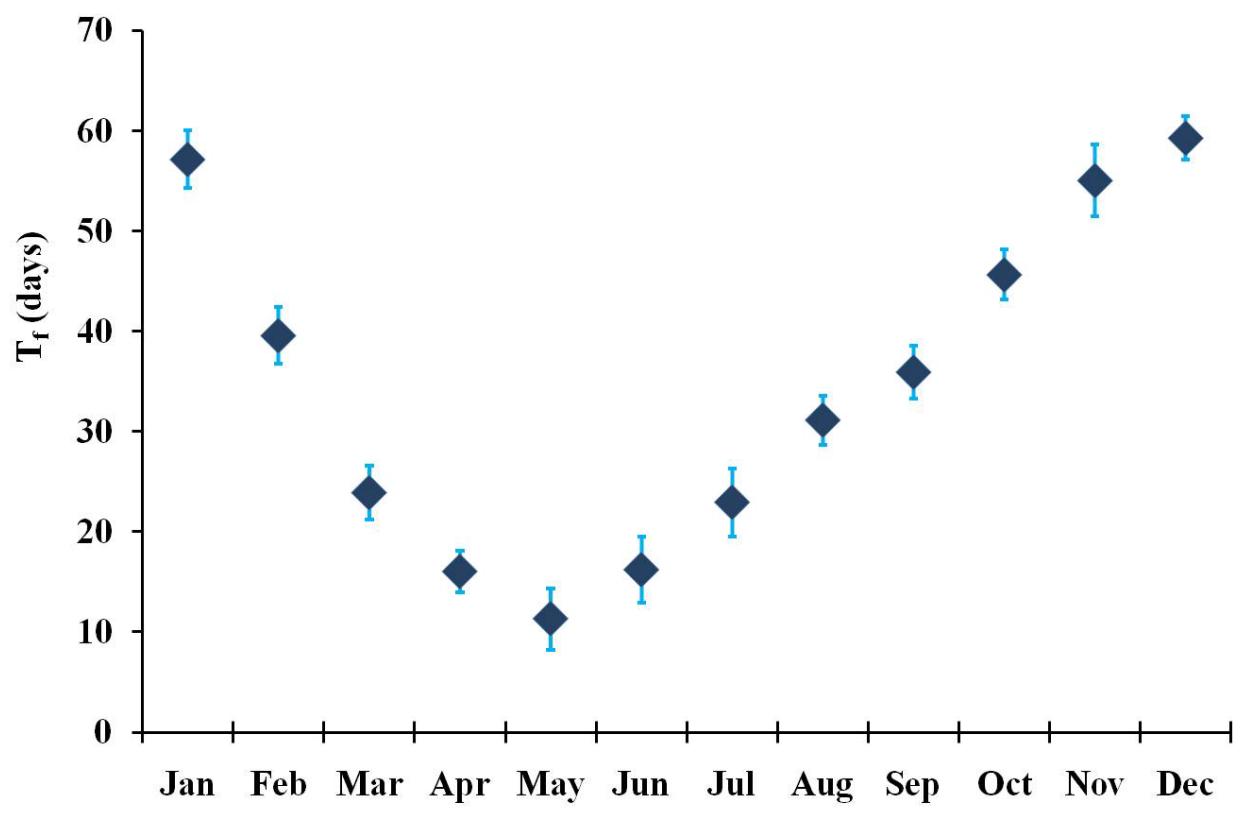

Figure 3.3. Taylor Slough average flushing times (days) by month for $2001-2011$ with standard error bars.

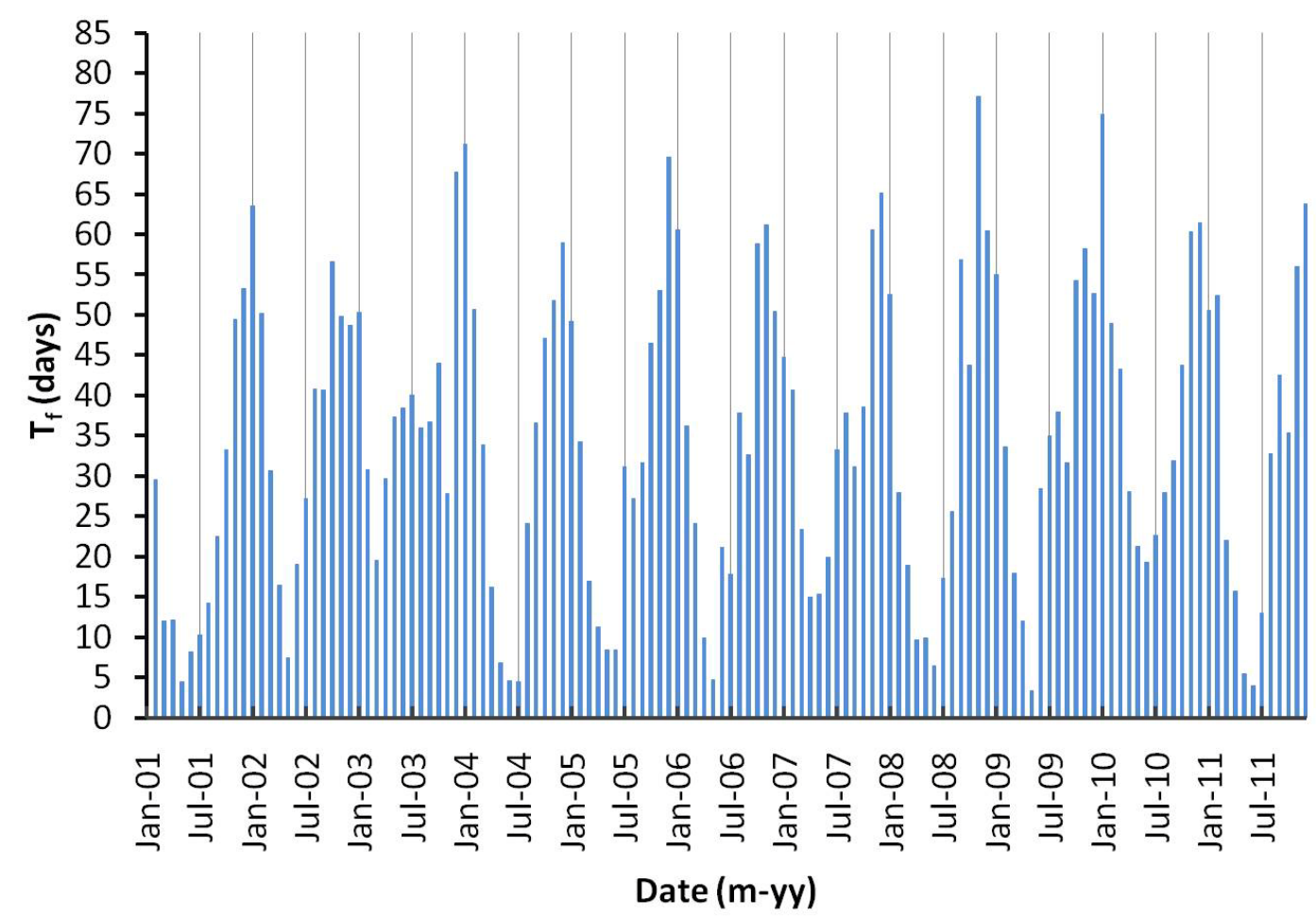

Figure 3.4. Taylor Slough monthly flushing times (days) from January 2001 - December 2011. 


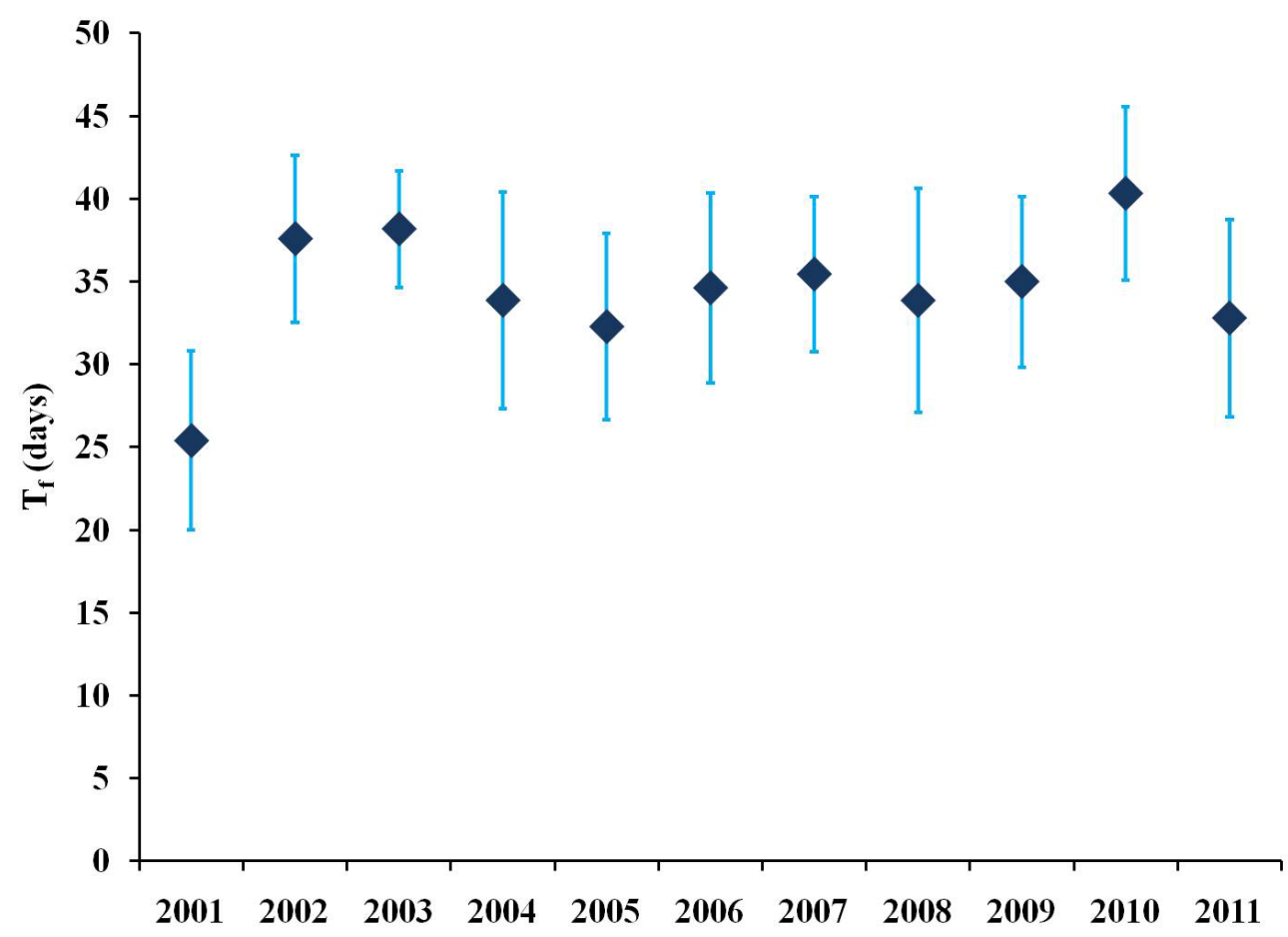

Figure 3.5. Taylor Slough yearly average flushing times with standard error bars for 2001 $-2011$.

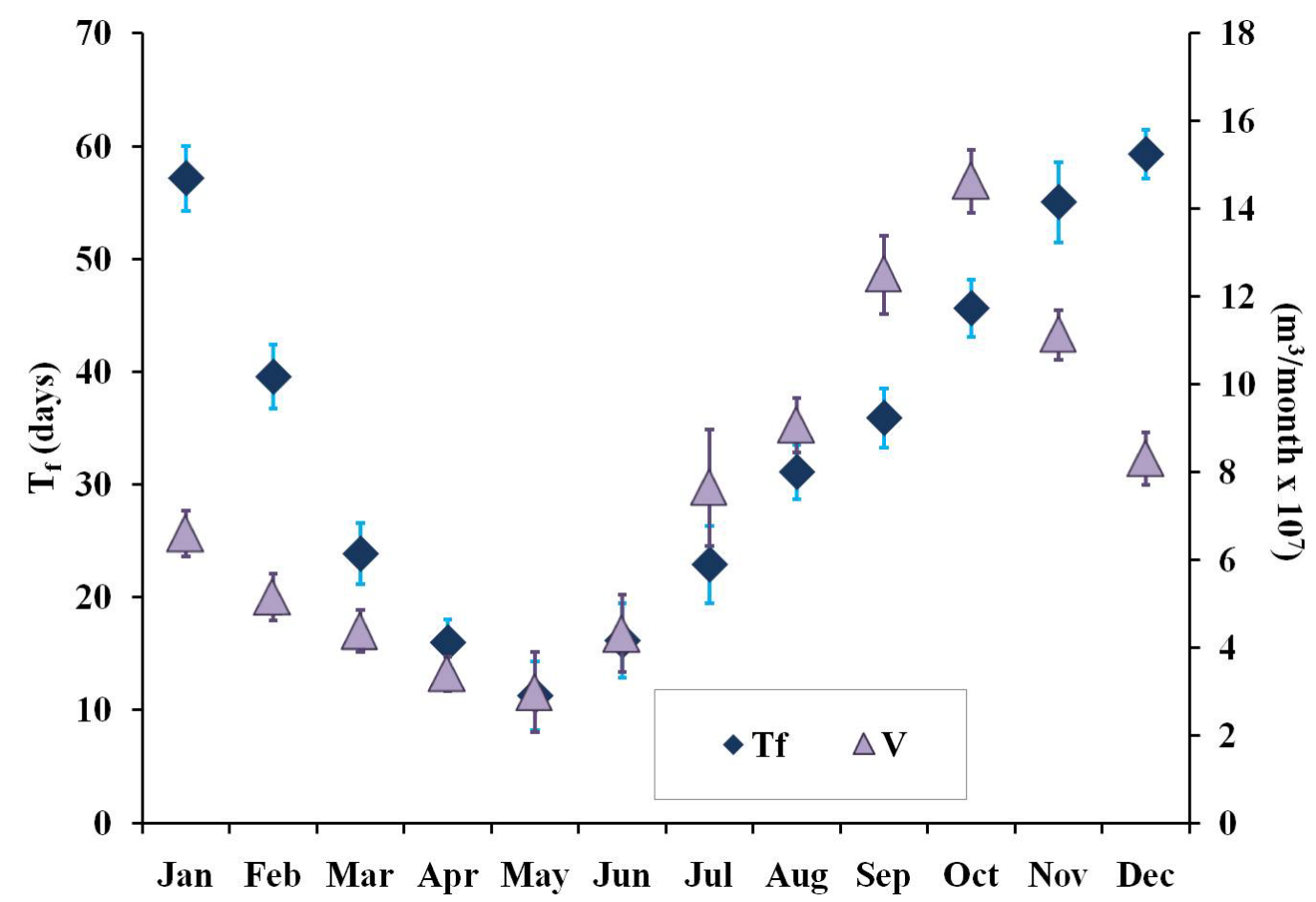

Figure 3.6. Monthly average volume, $\mathrm{V}$, (triangle) and flushing time, $\mathrm{T}_{\mathrm{f}}$, (diamond) for southern Taylor Slough with standard error bars for January 2001 - December 2011. 


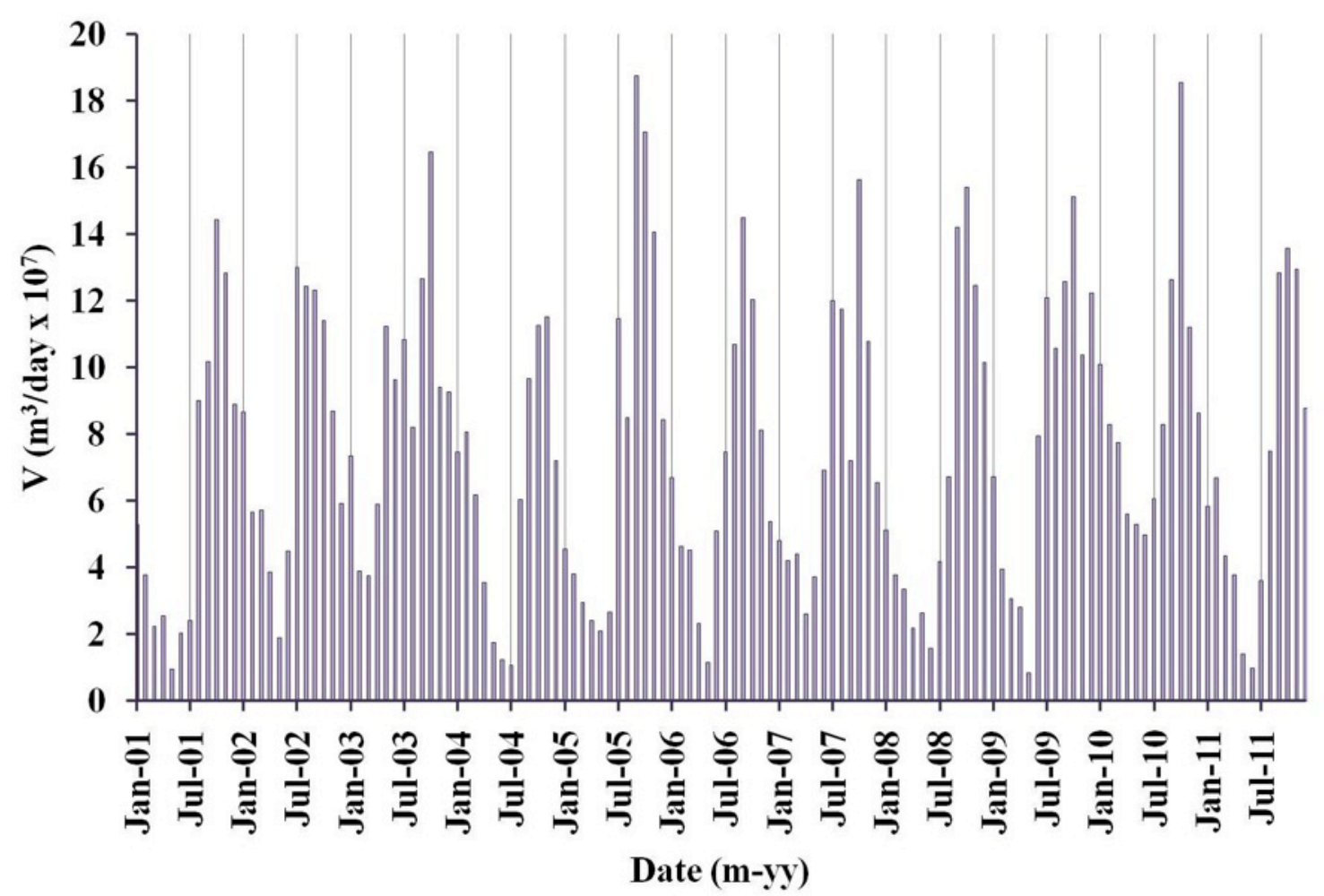

Figure 3.7. Monthly volume for southern Taylor Slough for January 2001 - December 2011.

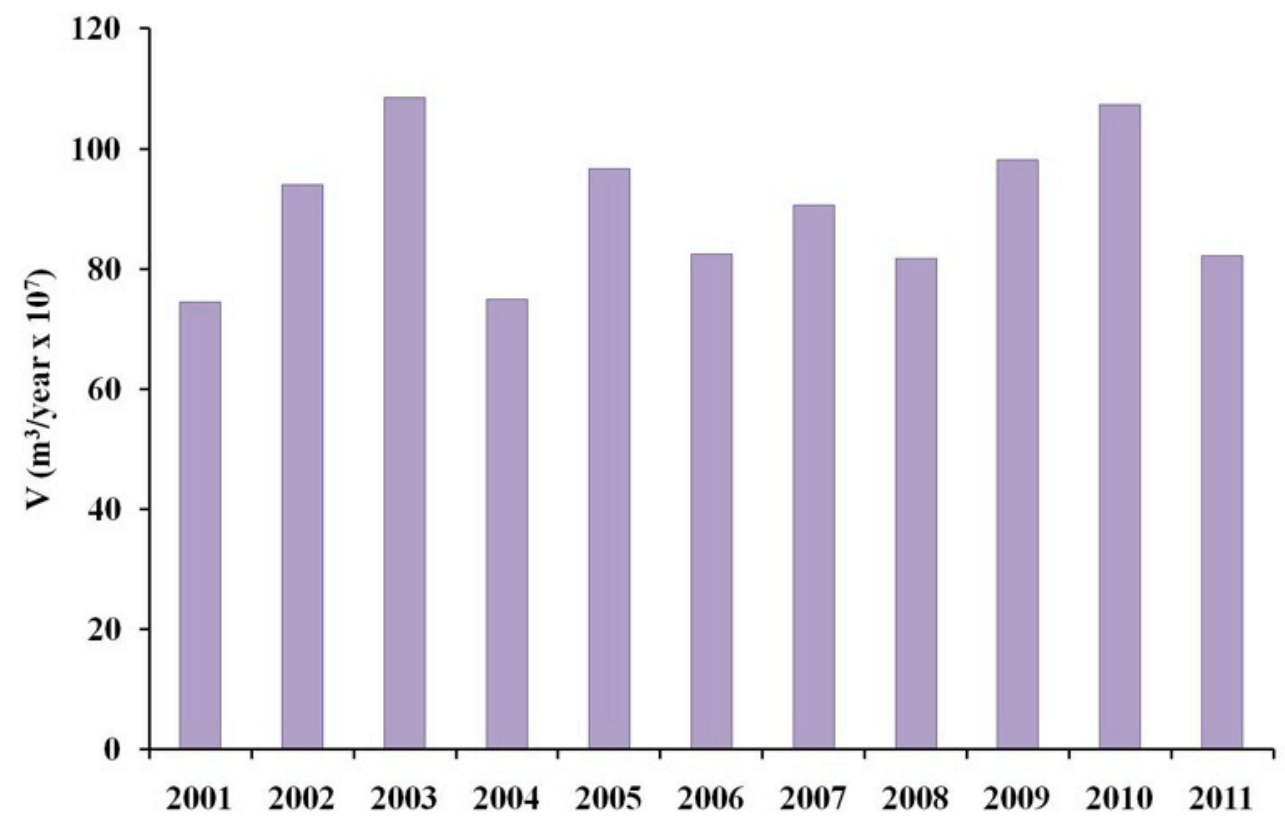

Figure 3.8. Yearly total volume for southern Taylor Slough for $2001-2011$. 


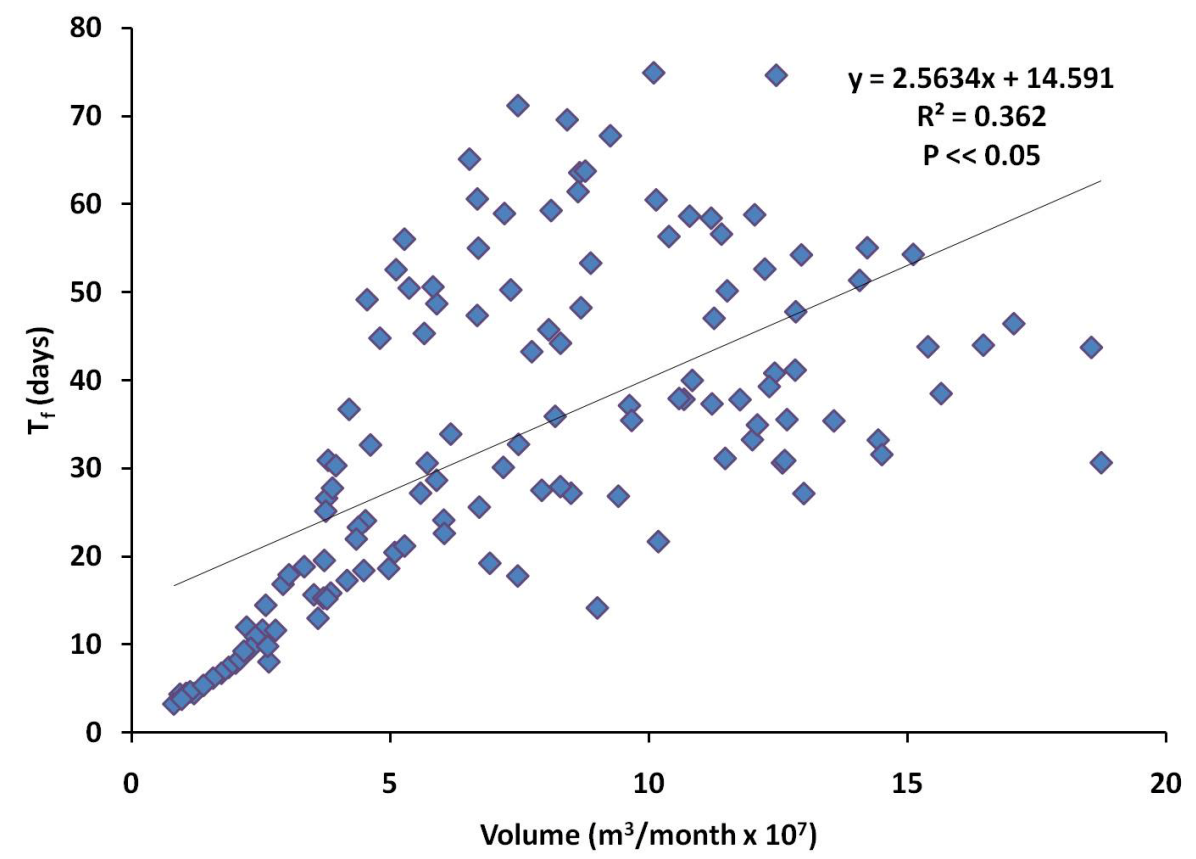

Figure 3.9. Volume vs. Flushing times for southern Taylor Slough for January 2001 December 2011.

Precipitation $(P)$

Precipitation data derived from the rasters created in GIS showed a seasonal bimodal distribution (Figure 3.10). During the span of 2001-2011, the highest average precipitation values exceeded $20 \mathrm{~cm}$ in August and September (Figure 3.10). The monthly averages were below the Royal Palm Ranger Station $(1970$ - 2011) monthly averages. The month with the highest precipitation was August $2001(37.14 \mathrm{~cm})$ and the lowest was February 2011(.281 cm) (Figure 3.11). The yearly total sums from 2002 2004 and 2006 - 2011 were below the Royal Palm Station (RPL) 30-year average of $132.44 \mathrm{~cm}$ with 2001 and 2005 exceeding the 30-year average (Figure 3.12). 


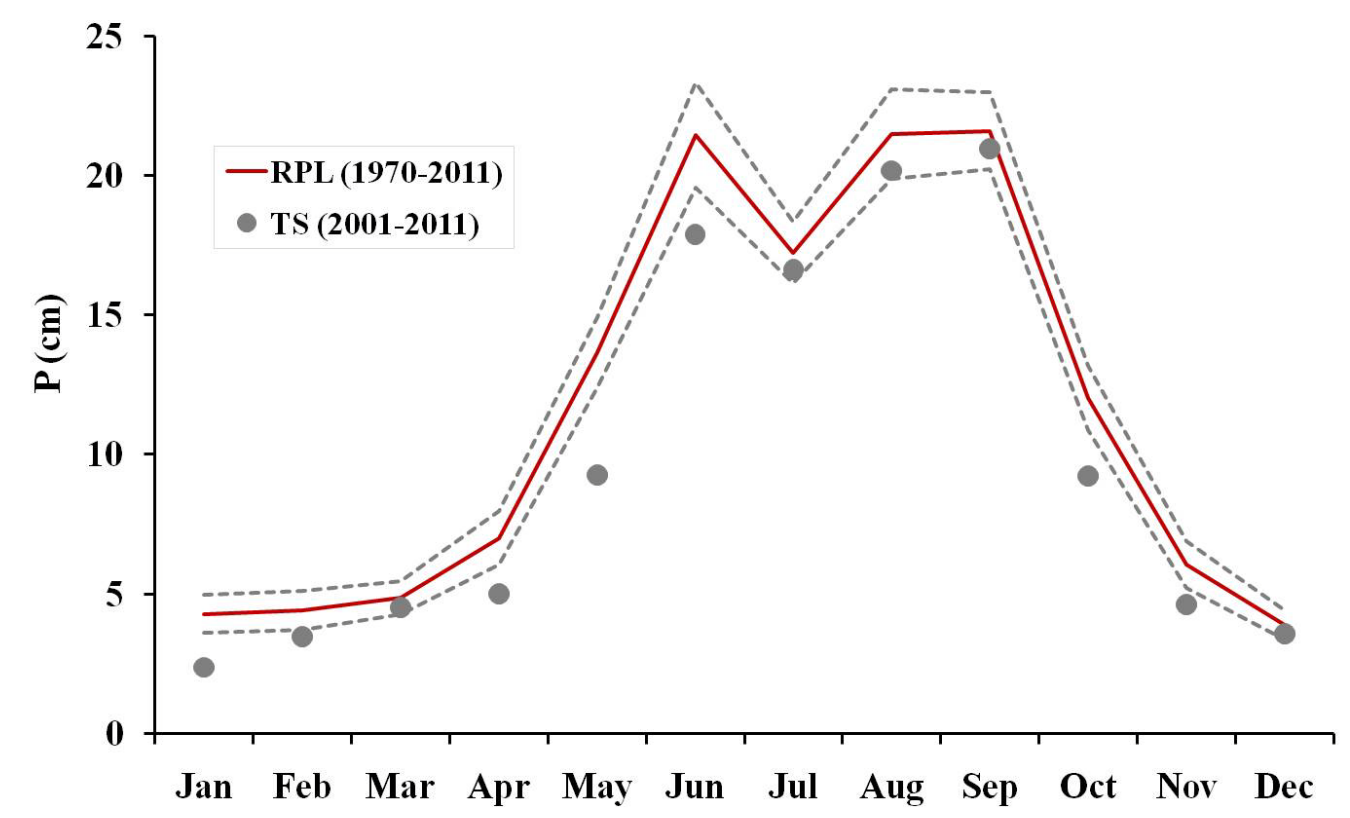

Figure 3.10. Mean monthly rainfall (cm) for southern Taylor Slough from $2001-2011$. Standard error bars for the mean rainfall are smaller than the labels. The solid line represents the 30-year mean monthly average for Royal Palm Ranger Station (RPL) from $1970-2011$ and the dashed lines represent the + standard error for RPL.

Surface Water Inflow $\left(Q_{\text {in }}\right)$ and Surface Water Outflow $\left(Q_{\text {out }}\right)$

Surface water inflow at TSB varied seasonally, increasing in April with an average value of $1.05 \times 10^{5} \mathrm{~m}^{3} /$ month, peaking in September with an average value of $1.67 \times 10^{7} \mathrm{~m}^{3} /$ month, and decreasing from October to March with average values of 1.43 $\mathrm{x} 10^{7} \mathrm{~m}^{3} /$ month and $7.10 \times 10^{4} \mathrm{~m}^{3} /$ month respectively (Figure 3.13 ). September 2005 was the month with the highest discharge between 2001 and 2011 with a value of $3.5 \times 10^{7}$ $\mathrm{m}^{3} /$ month (Figure 3.14); February - April 2001, April - June 2004, April 2006, March 2007, January and May 2008, April 2009, February - March 2010, and March - May 2011 were months with zero discharge into southern Taylor Slough (Figure 3.14). Year 
2005 had the highest total discharge $\left(1.14 \times 10^{8} \mathrm{~m}^{3} /\right.$ year $)$ into southern Taylor Slough while Year 2007 had the lowest discharge value of $1.79 \times 10^{7} \mathrm{~m}^{3} /$ year (Figure 3.15).

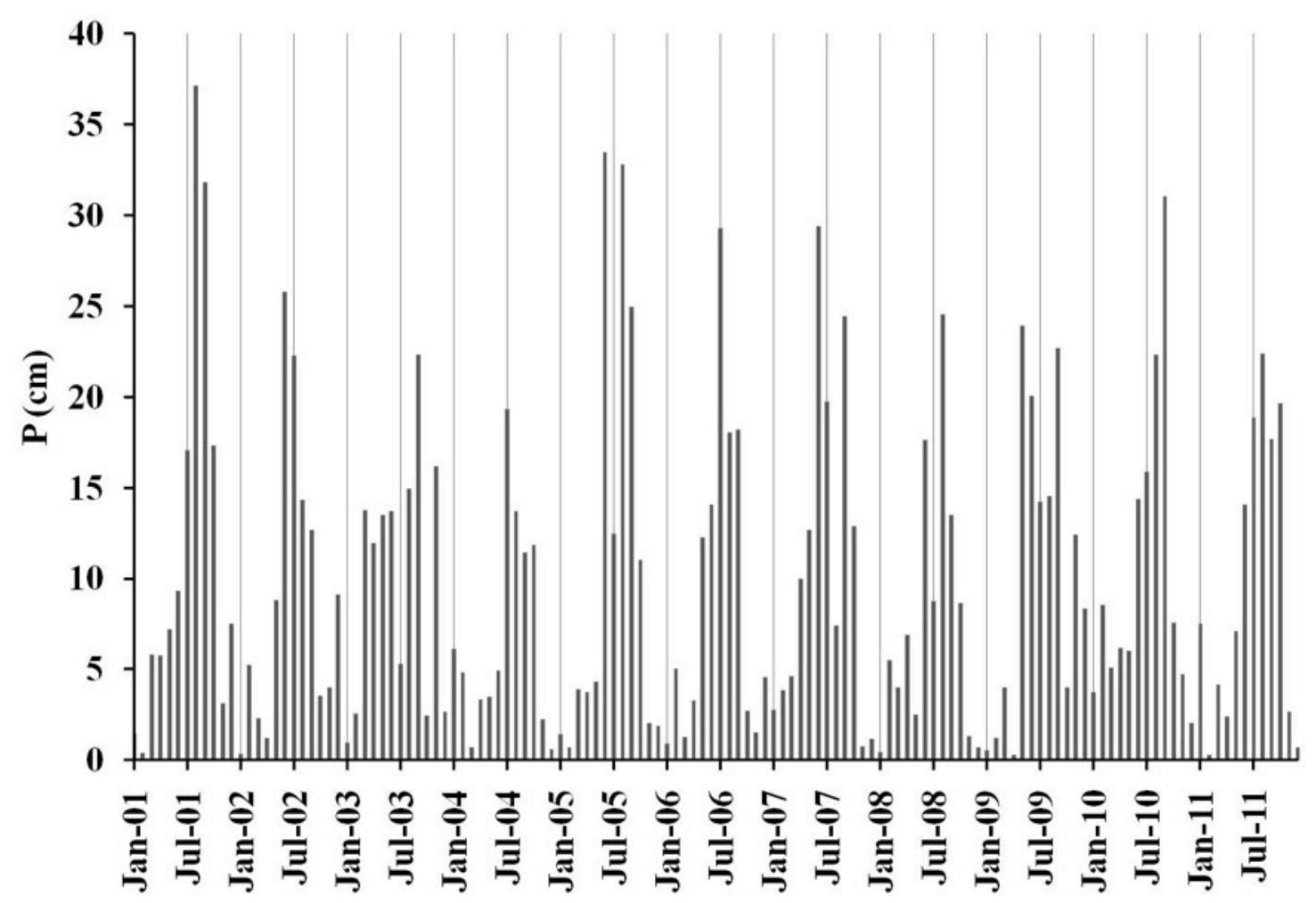

Date (m-yy)

Figure 3.11. Taylor Slough total monthly precipitation from January 2001 - December 2012.

Positive surface water outflow ( $\left.\mathrm{Q}_{\text {out }}\right)$ values indicated water flowing into Taylor Slough from Florida Bay while negative values indicated water flowing out of Taylor Slough and into Florida Bay. On average, southern Taylor Slough had a peak discharge into Florida Bay during the month of September with an average value of $-2.66 \times 10^{7}$ $\mathrm{m}^{3} /$ month (Figure 3.16). Surface water discharge to Florida Bay started decreasing in October through February with average values of $-2.56 \times 10^{7} \mathrm{~m}^{3} /$ month and $-1.92 \times 10^{6}$ $\mathrm{m}^{3} /$ month respectively. March through May were, on average, months where Florida Bay 
water flowed into southern Taylor Slough; the highest inflow from Florida Bay into southern Taylor Slough was in the month of May with an average value of $4.98 \times 10^{6}$ $\mathrm{m}^{3} /$ month.

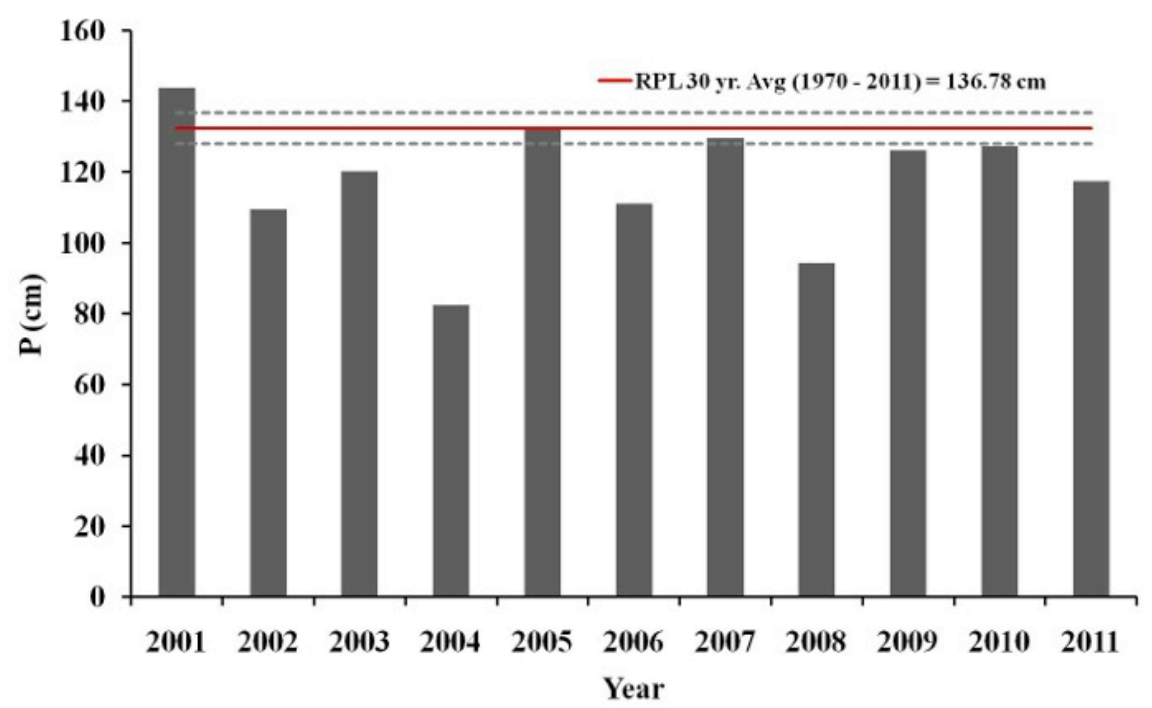

Figure 3.12. Total annual precipitation $(\mathrm{cm})$ for southern Taylor Slough. The 30-year yearly average with standard error lines for RPL is also shown.

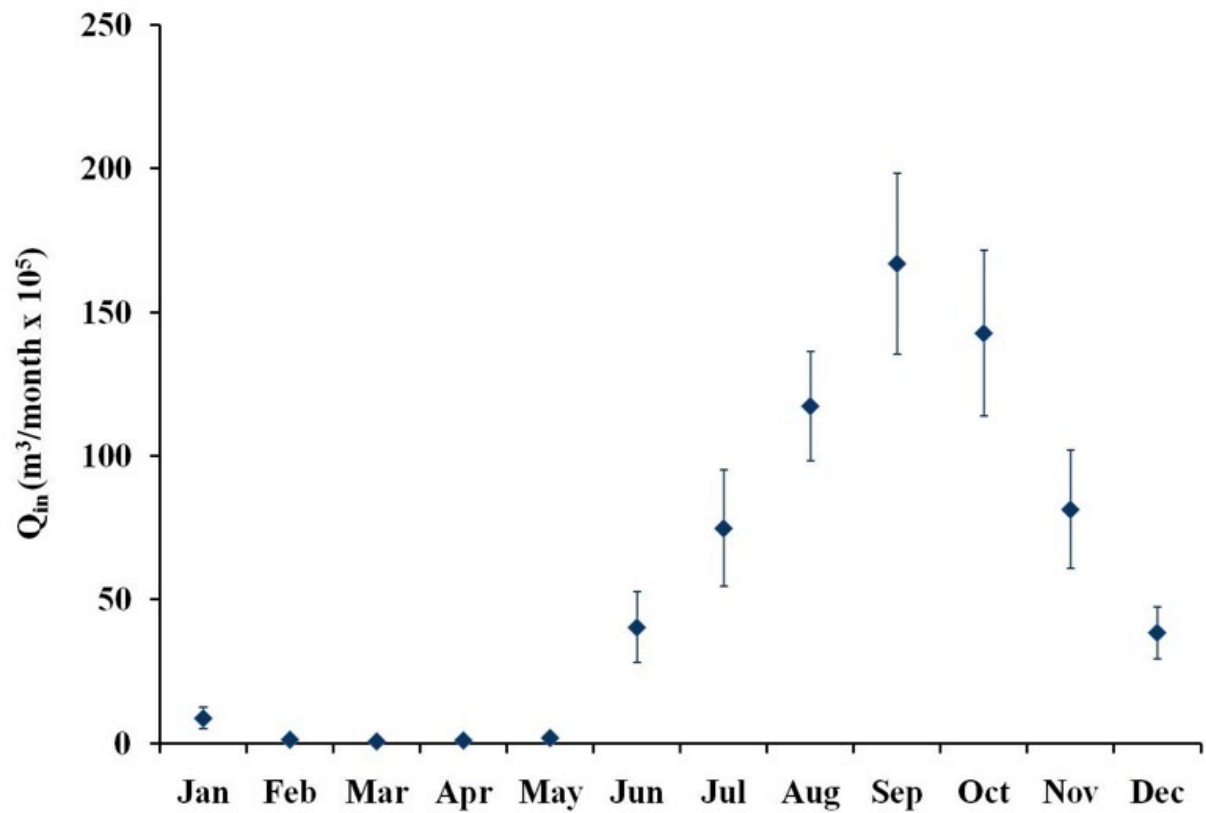

Figure 3.13. Average monthly surface water inflows from TSB for $2001-2011$ with standard error bars. 


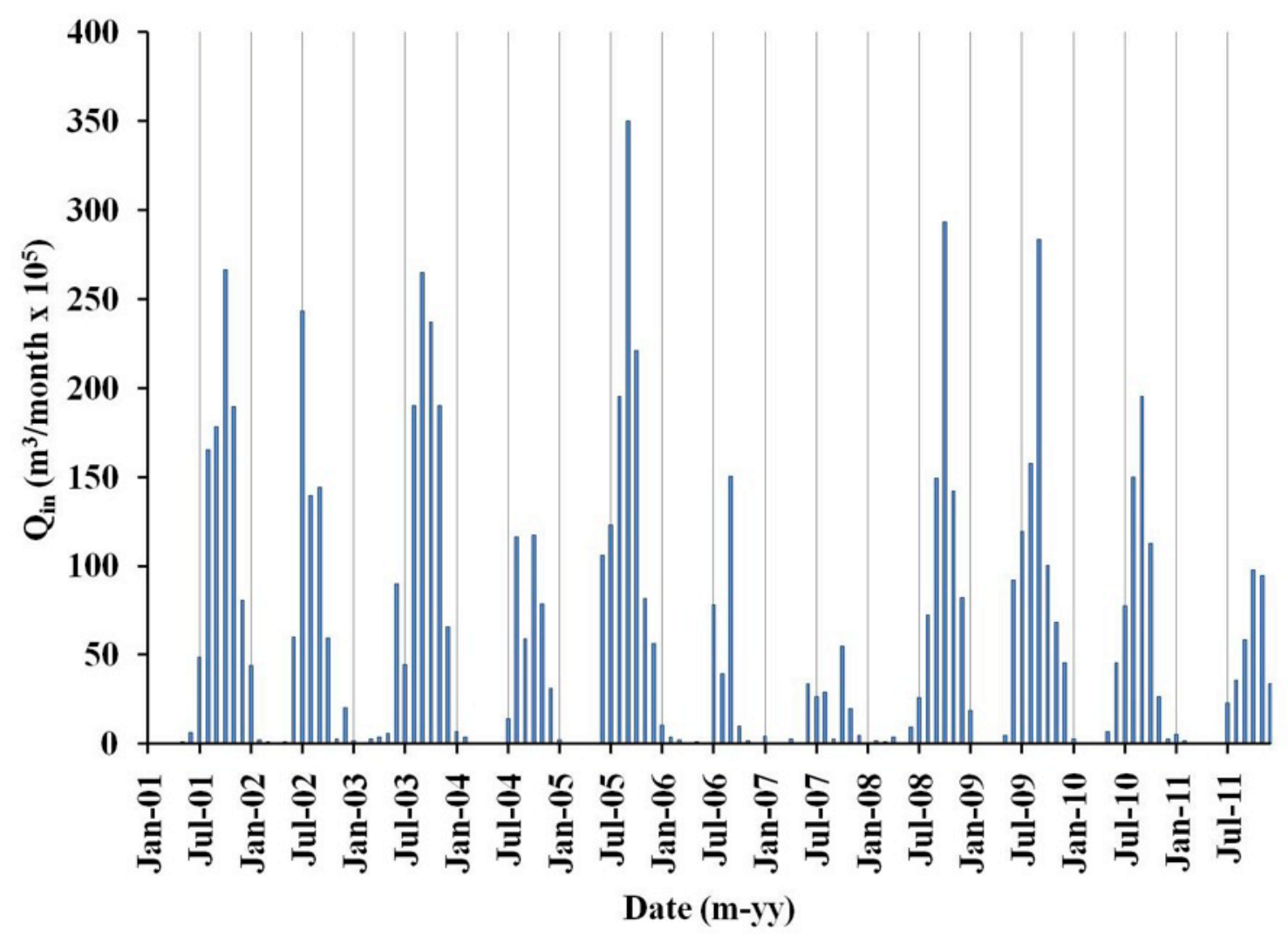

Figure 3.14. Monthly surface water inflow from TSB from January 2008 to December 2011.

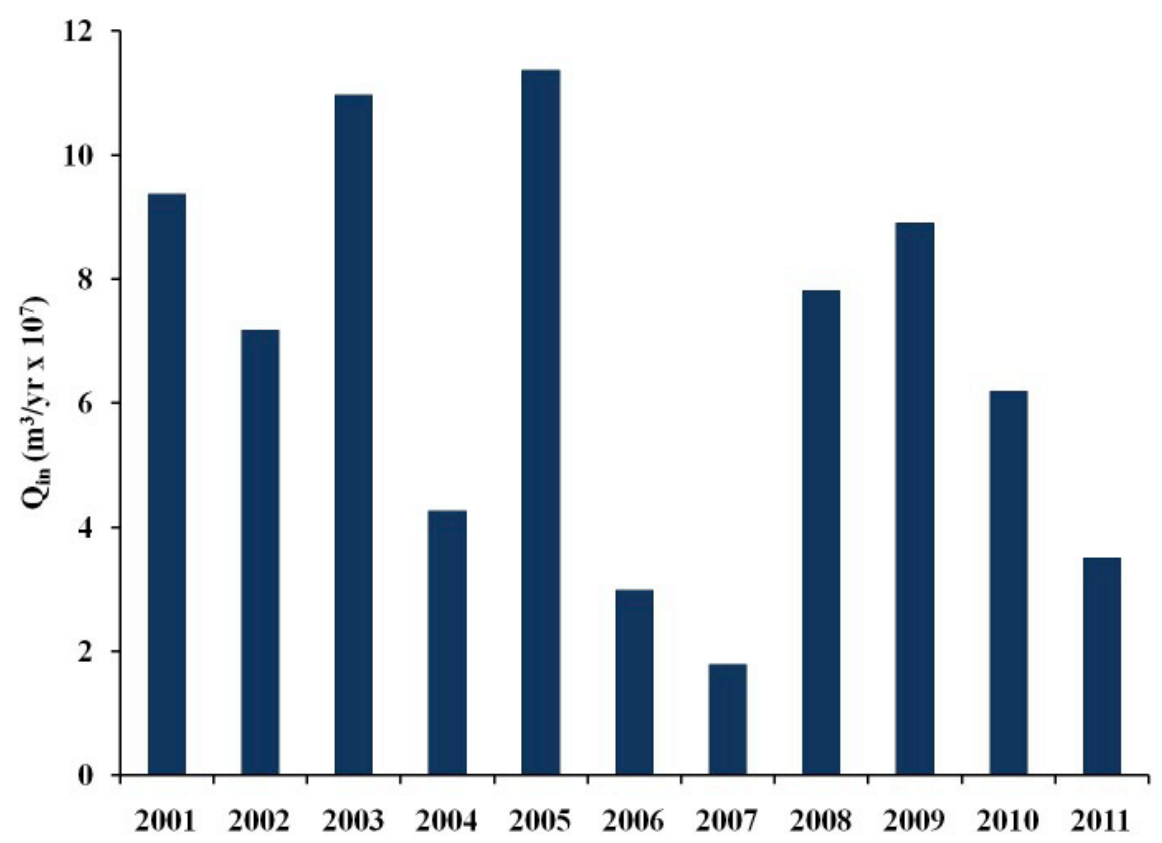

Figure 3.15. Yearly total sums of surface water inflow from TSB into southern Taylor Slough for $2001-2011$. 
Discharge into Florida Bay commenced again in June with an average value of $5.30 \times 10^{6} \mathrm{~m}^{3} /$ month, increasing through September. The month with the highest discharge value to Florida Bay was September 2005 with a value of $-6.53 \times 10^{7} \mathrm{~m}^{3} / \mathrm{month}$ (Figure 3.17). June 2009 had the highest inflow, of $1.30 \times 10^{7} \mathrm{~m}^{3} /$ year, during the ten years. Year 2005 had the highest discharge values, $-1.73 \times 10^{8} \mathrm{~m}^{3} /$ year, to Florida Bay of the ten years observed in this study while 2011 had the lowest with $-5.5 \times 10^{7} \mathrm{~m}^{3} /$ year (Figure 3.18). Surface water outflow had a similar trend to Qin when the absolute values of Qout were compared to Qin for Taylor Slough (Figure 3.19) with both Qout and Qin increasing during the same months.

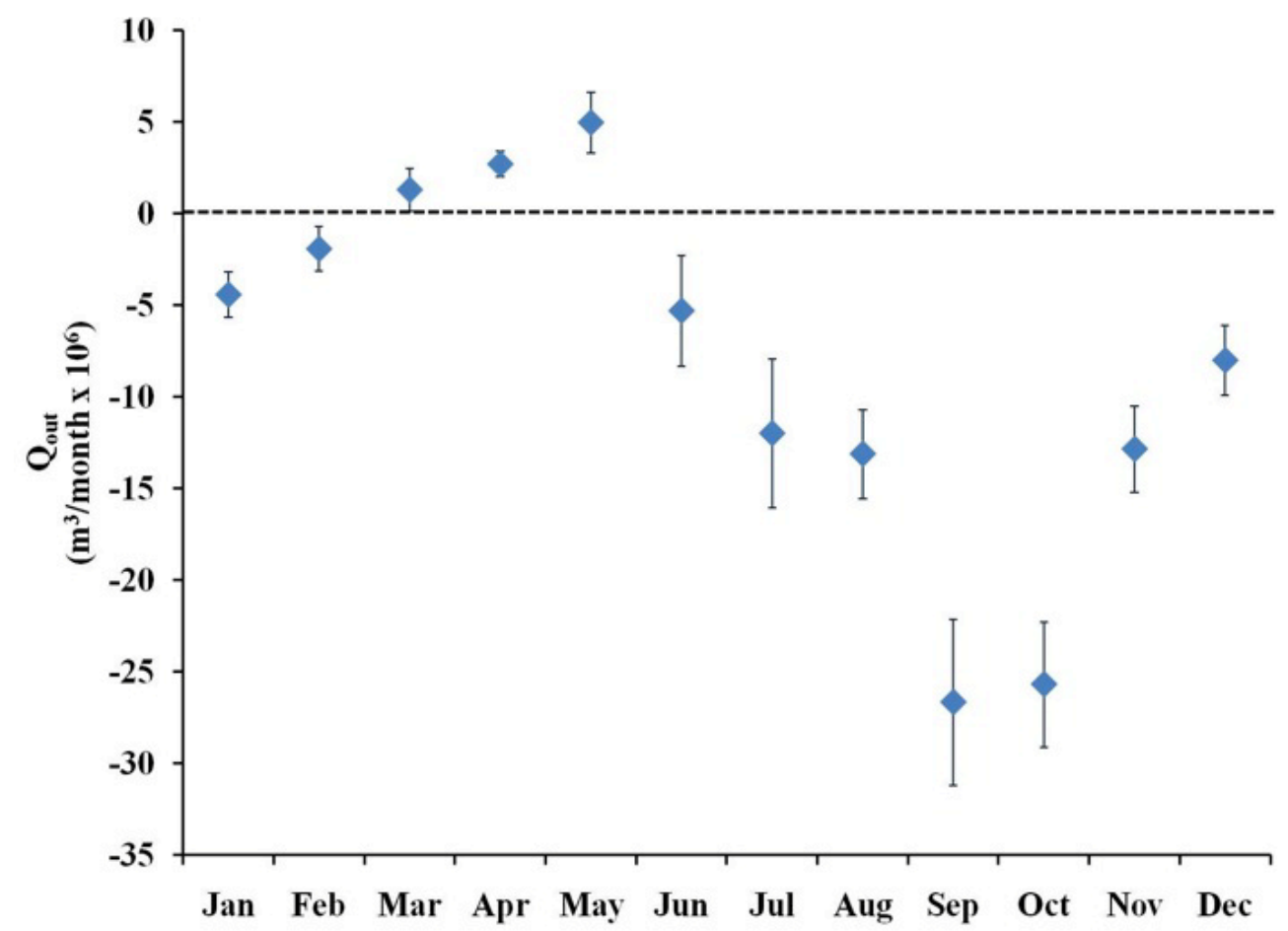

Figure 3.16. Average monthly surface water outflow (with standard error bars) for southern Taylor Slough from January 2001 - December 2011. Positive values indicate surface water flowing into Taylor Slough from Florida Bay; Negative values indicate surface water flowing out of Taylor Slough to Florida Bay. 


\section{Evapotranspiration (ET)}

The average monthly evapotranspiration values had bi-modal distribution during the ten-year study peaking in May $\left(7.68 \times 10^{7} \mathrm{~m}^{3} / \mathrm{month}\right)$ and lowest values in December (2.70 $\times 10^{7} \mathrm{~m}^{3} / \mathrm{month}$ ) (Figure 3.20). The lowest $E T$ value during the ten-year period occurred in December 2010 with a value of $2.36 \times 10^{7} \mathrm{~m}^{3} /$ month with the highest occurring in May 2008 with a value of $8.29 \times 10^{7} \mathrm{~m}^{3} /$ month (Figure 3.21). The year with the highest total ET was 2011 with a total sum of $6.82 \times 10^{8} \mathrm{~m}^{3} /$ year while 2001,2003 , and 2010 had the lowest with $6.36 \times 10^{8} \mathrm{~m}^{3} /$ year (Figure 3.22). Evapotranspiration had a negative correlation with $\mathrm{T}_{\mathrm{f}}$, having an R-squared value of $0.449(\mathrm{P}<<0.05)$ (Figure

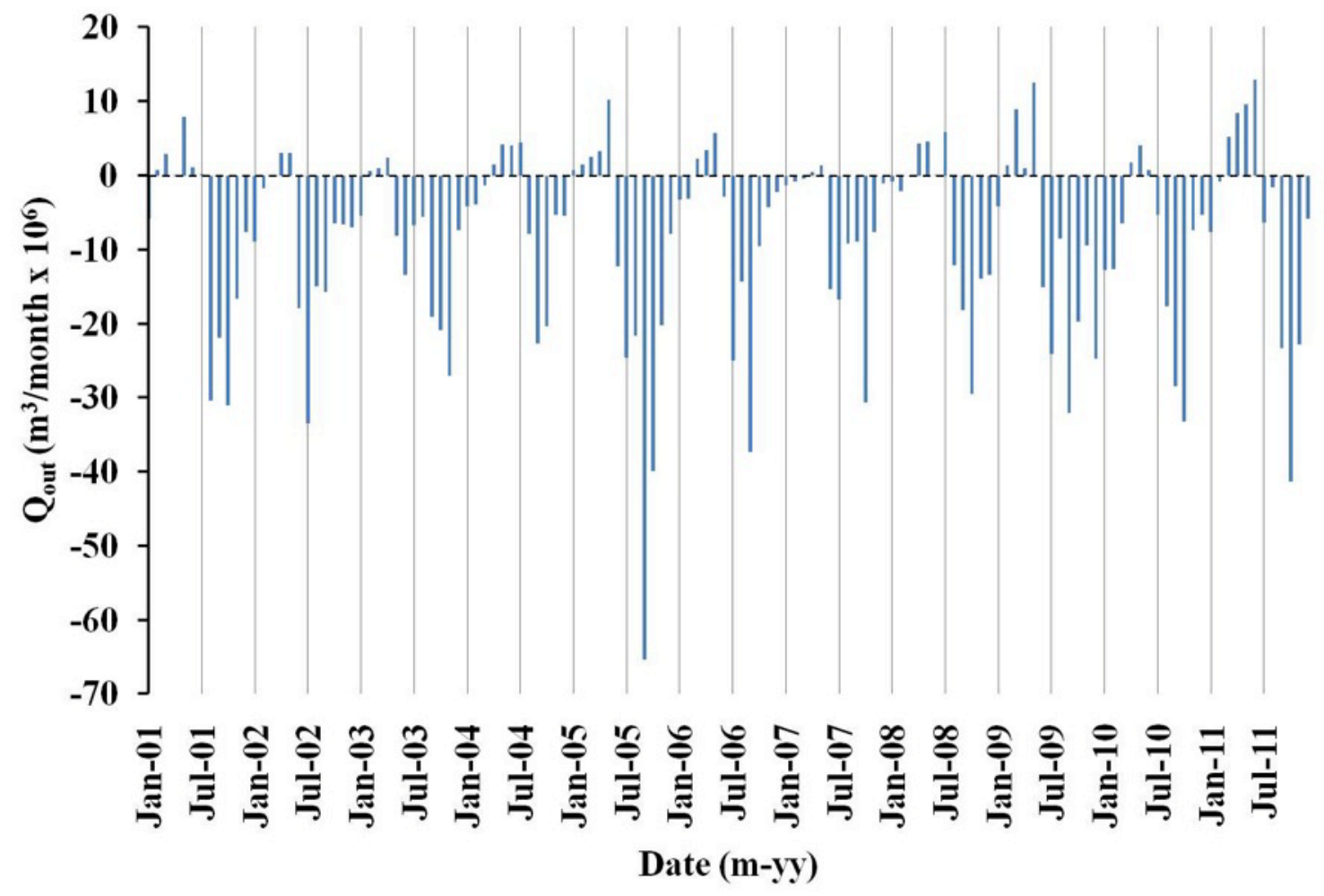

Figure 3.17. Monthly surface water outflow for southern Taylor Slough from January 2001 - December 2011. Positive values indicate surface water flowing into Taylor Slough from Florida Bay; Negative values indicate surface water flowing out of Taylor Slough to Florida Bay. 


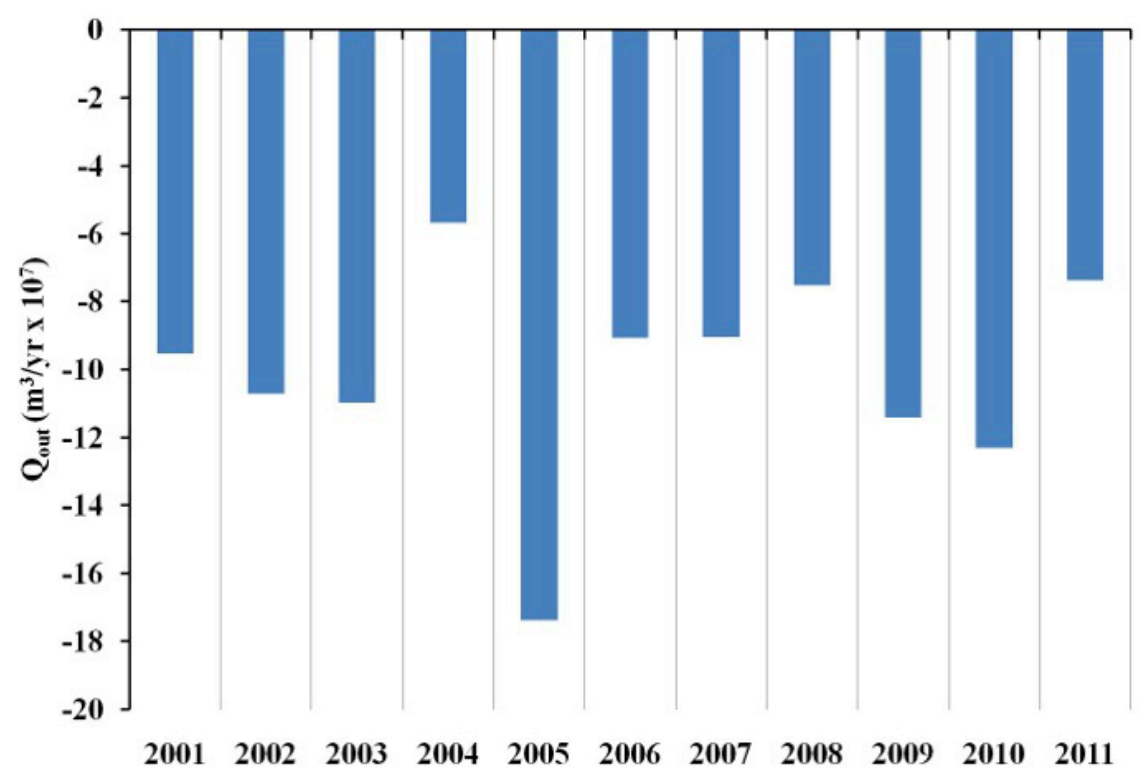

Figure 3.18. Total yearly sums of surface water discharge for southern Taylor Slough for $2001-2011$.

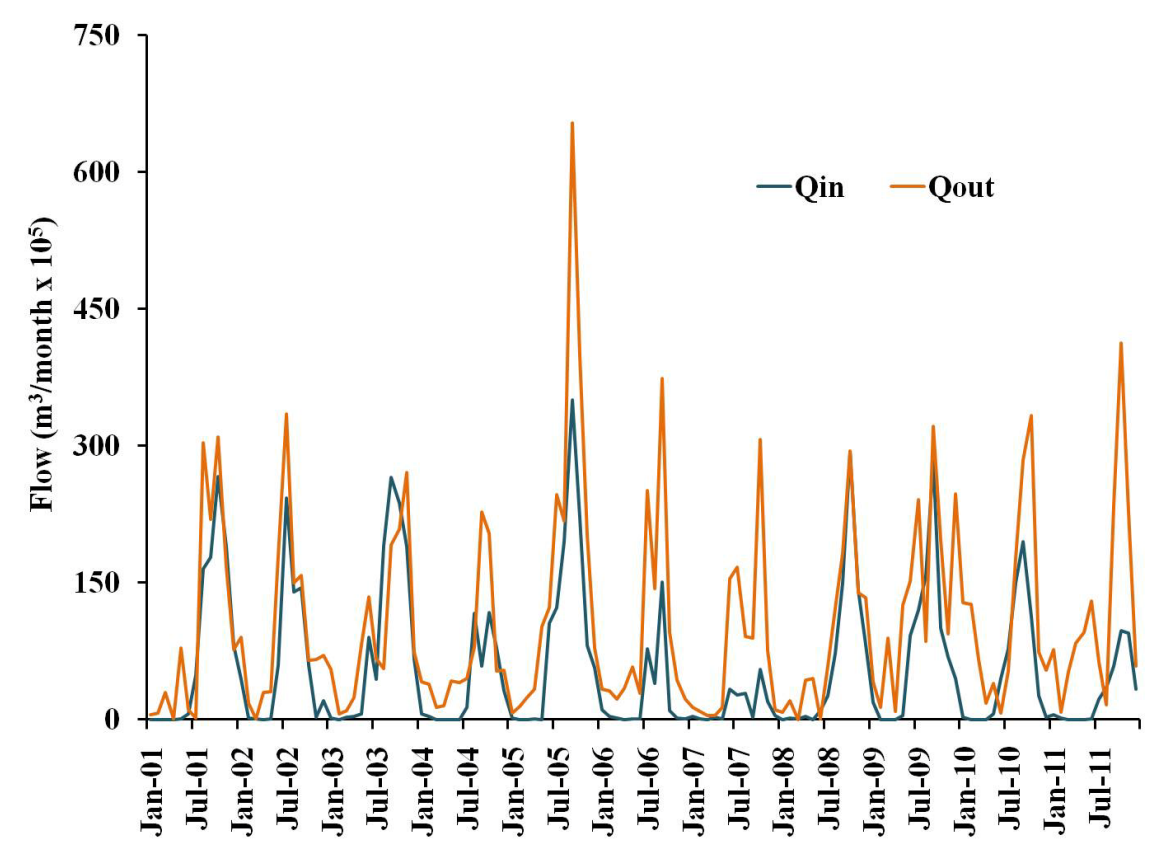

Figure 3.19. Monthly surface water inflow (Qin) and absolute values of surface water outflow (Qout) from January 2001 - December 2011 for Taylor Slough. 


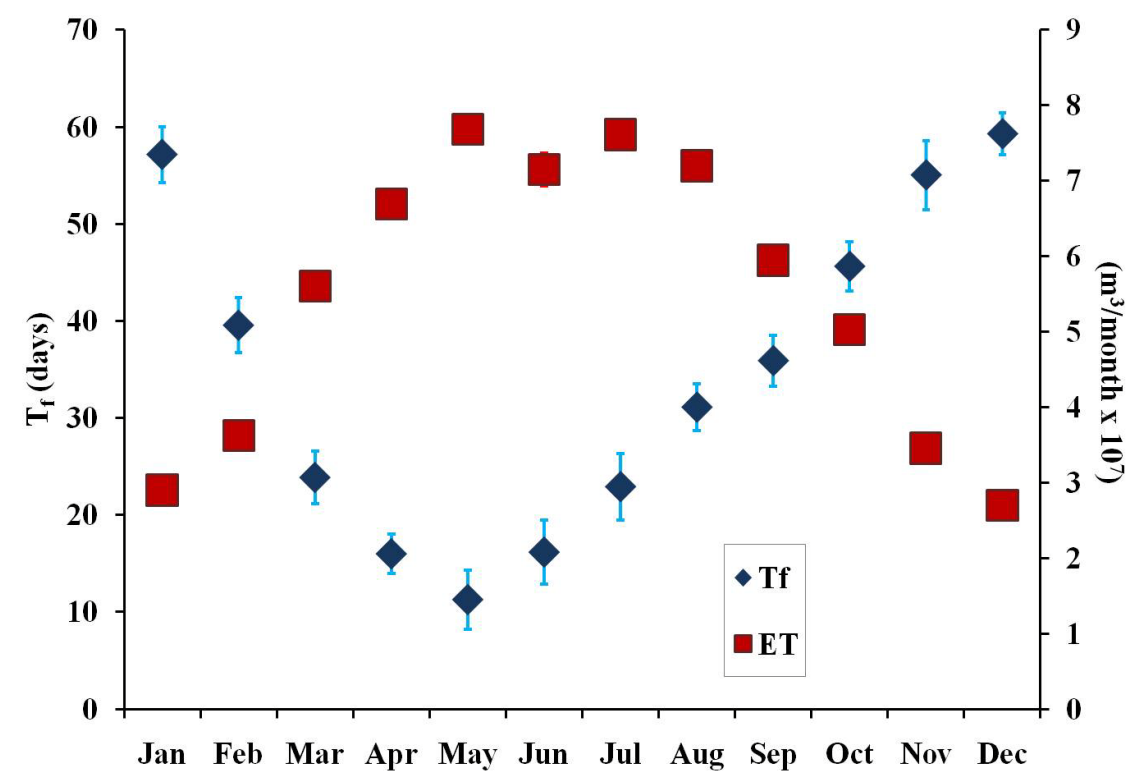

Figure 3.20. Monthly average evapotranspiration (square) and water flushing times (diamond) for southern Taylor Slough with standard error bars for January 2001 December 2011.

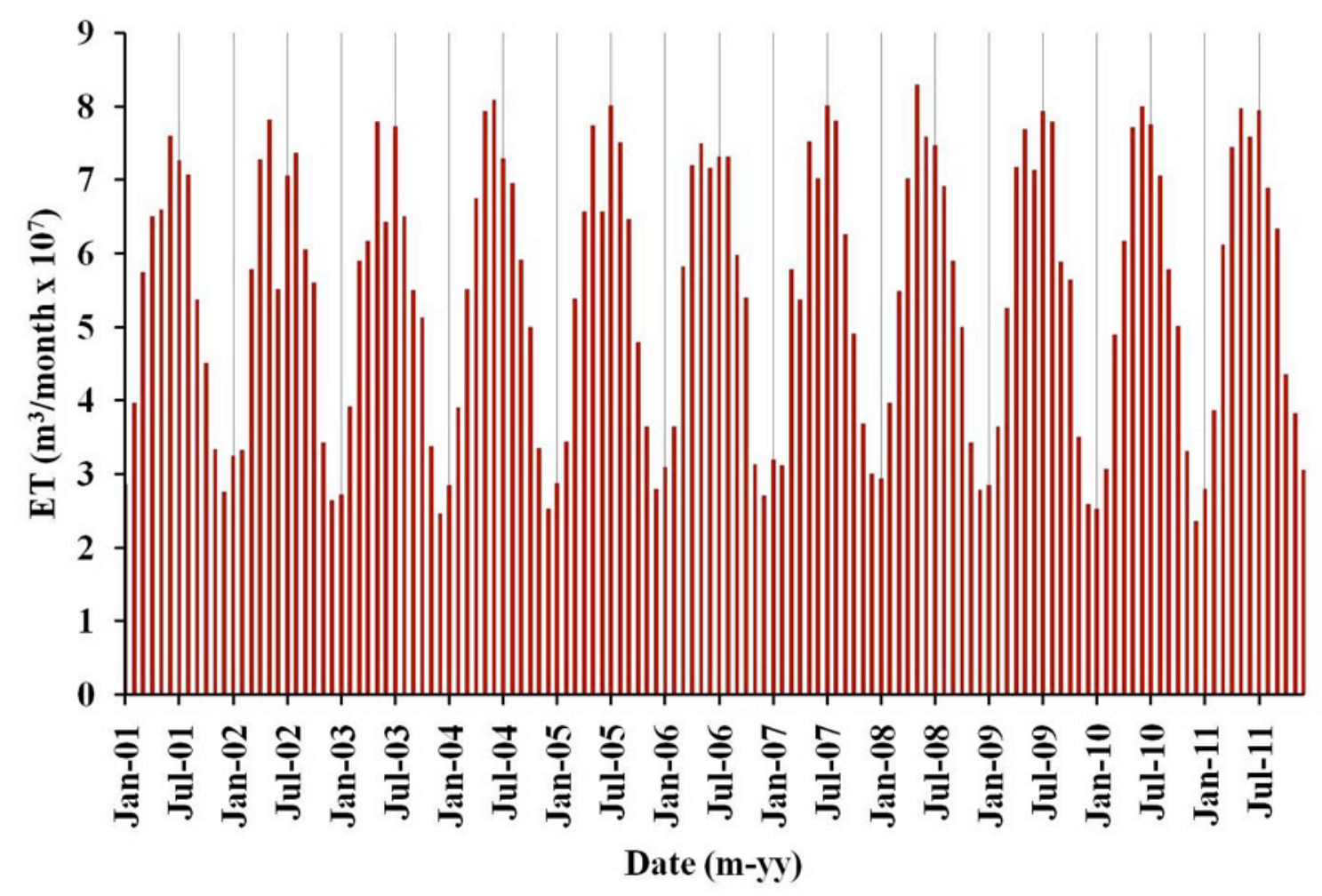

Figure 3.21. Monthly evapotranspiration for southern Taylor Slough for January 2001 December 2011. 


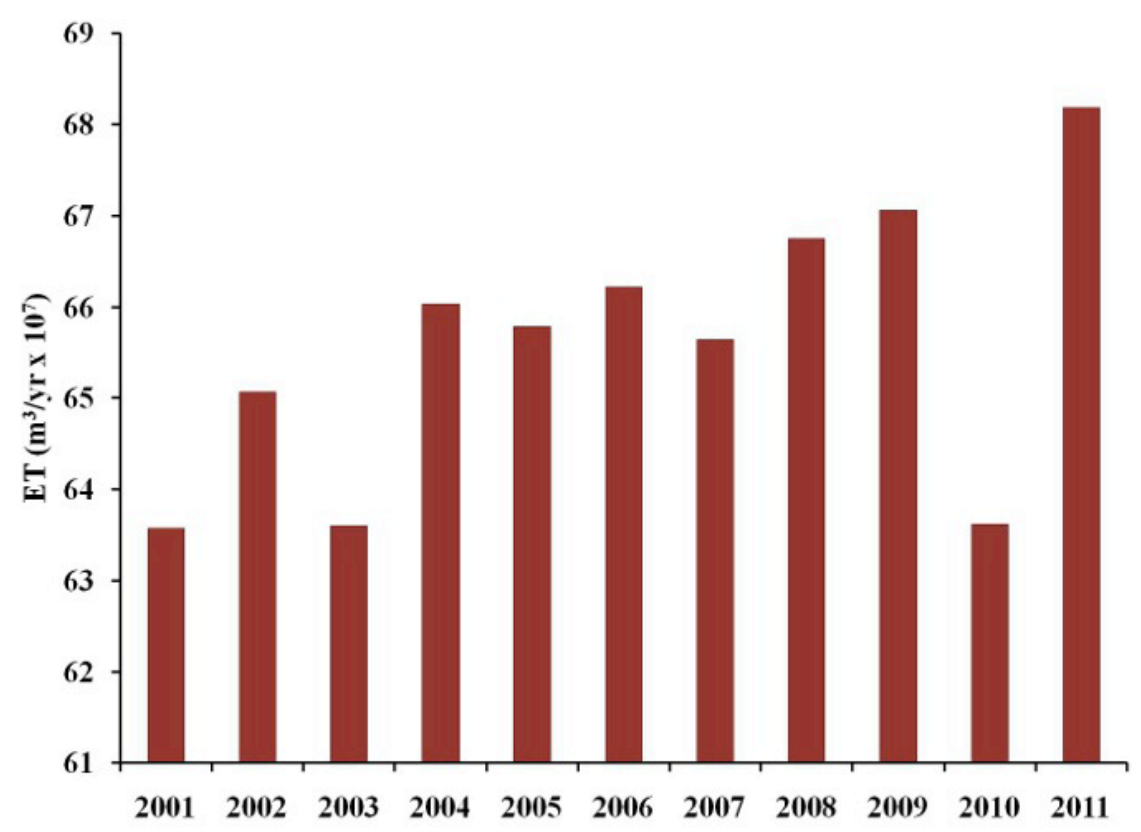

Figure 3.22. Yearly total sums of evapotranspiration for southern Taylor Slough for 2001 -2011 .

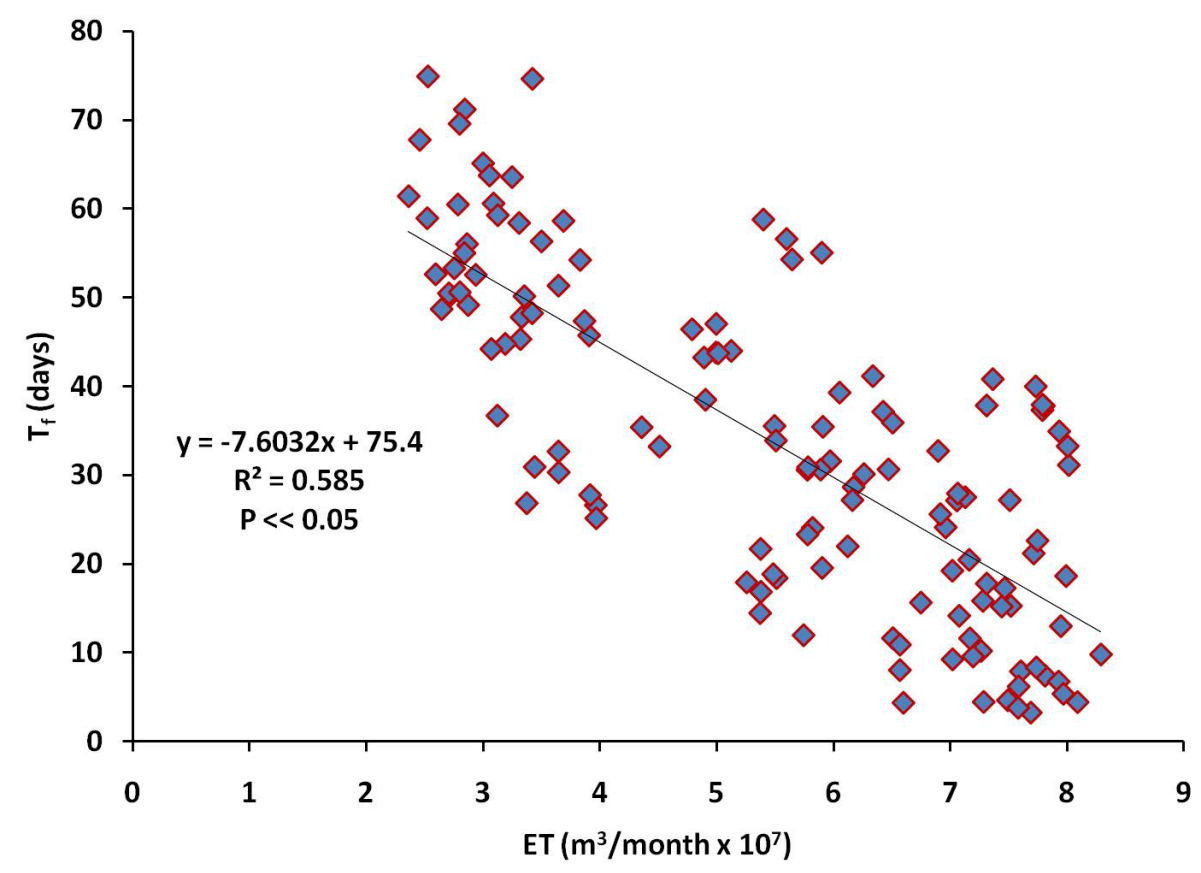

Figure 3.23. Evapotranspiration vs. Flushing times for southern Taylor Slough for January 2001 - December 2011. 
Change in Storage $(S)$

For the period of $2001-2011$, the month of August had the highest average $S$ values $\left(3.44 \times 10^{7} \mathrm{~m}^{3} / \mathrm{month}\right)$, while October had the lowest average $S$ values $\left(-3.50 \times 10^{7}\right.$ $\mathrm{m}^{3} / \mathrm{month}$; Figure 3.24). The highest $S$ value was observed in August 2005, and lowest in October 2010 with values of $1.03 \times 10^{8} \mathrm{~m}^{3} / \mathrm{month}$ and $-7.34 \times 10^{7} \mathrm{~m}^{3} / \mathrm{month}$, respectively (Figure 3.25$)$. Year 2010 had the largest negative change in storage $\left(-4.27 \times 10^{7} \mathrm{~m}^{3} /\right.$ year) while 2001 and 2009 had the highest positive change in storage $\left(3.39 \times 10^{7} \mathrm{~m}^{3} /\right.$ year $)$ (Figure 3.26).

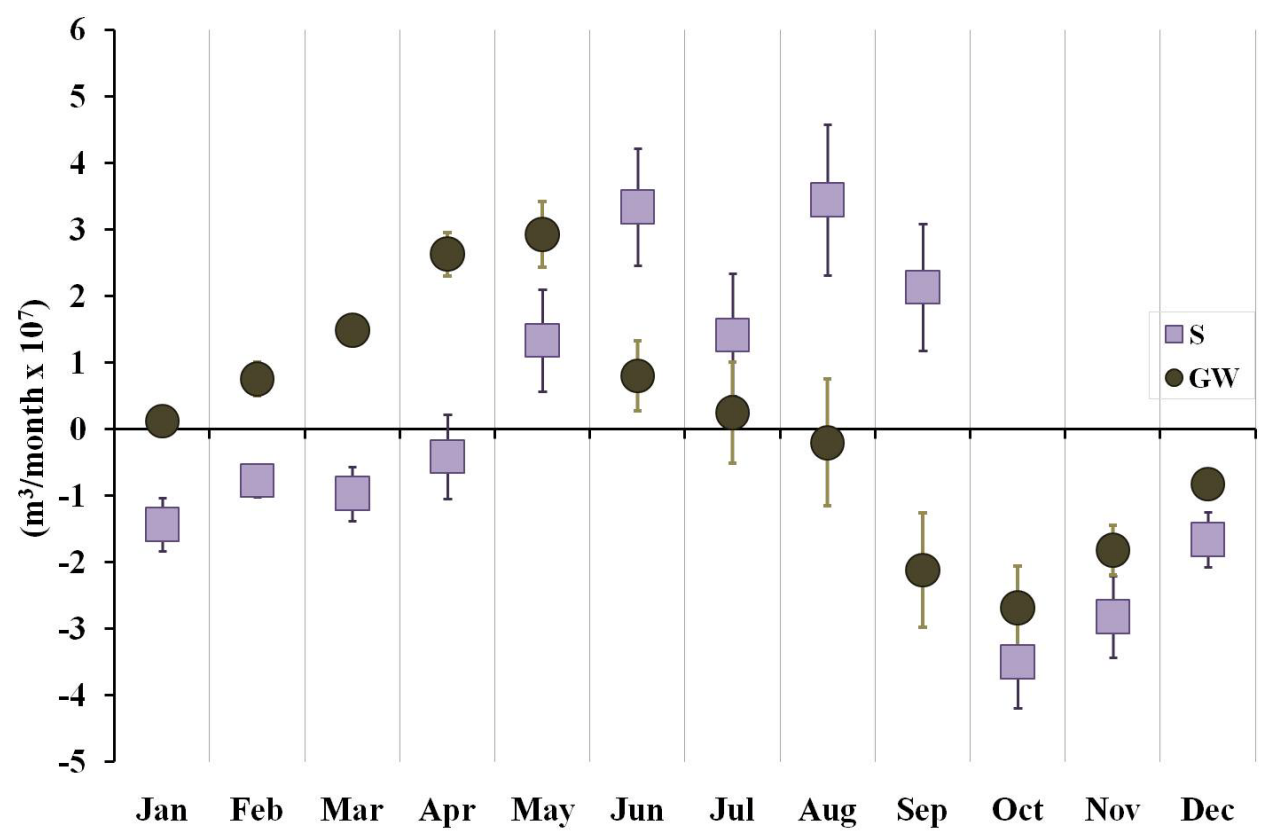

Figure 3.24. Monthly average values for change in storage (S) and groundwater (GW) with standard error bars for southern Taylor Slough for January 2001 - December 2011. Positive GW values indicate groundwater discharging into Taylor Slough while negative values indicate surface water recharging the groundwater. 


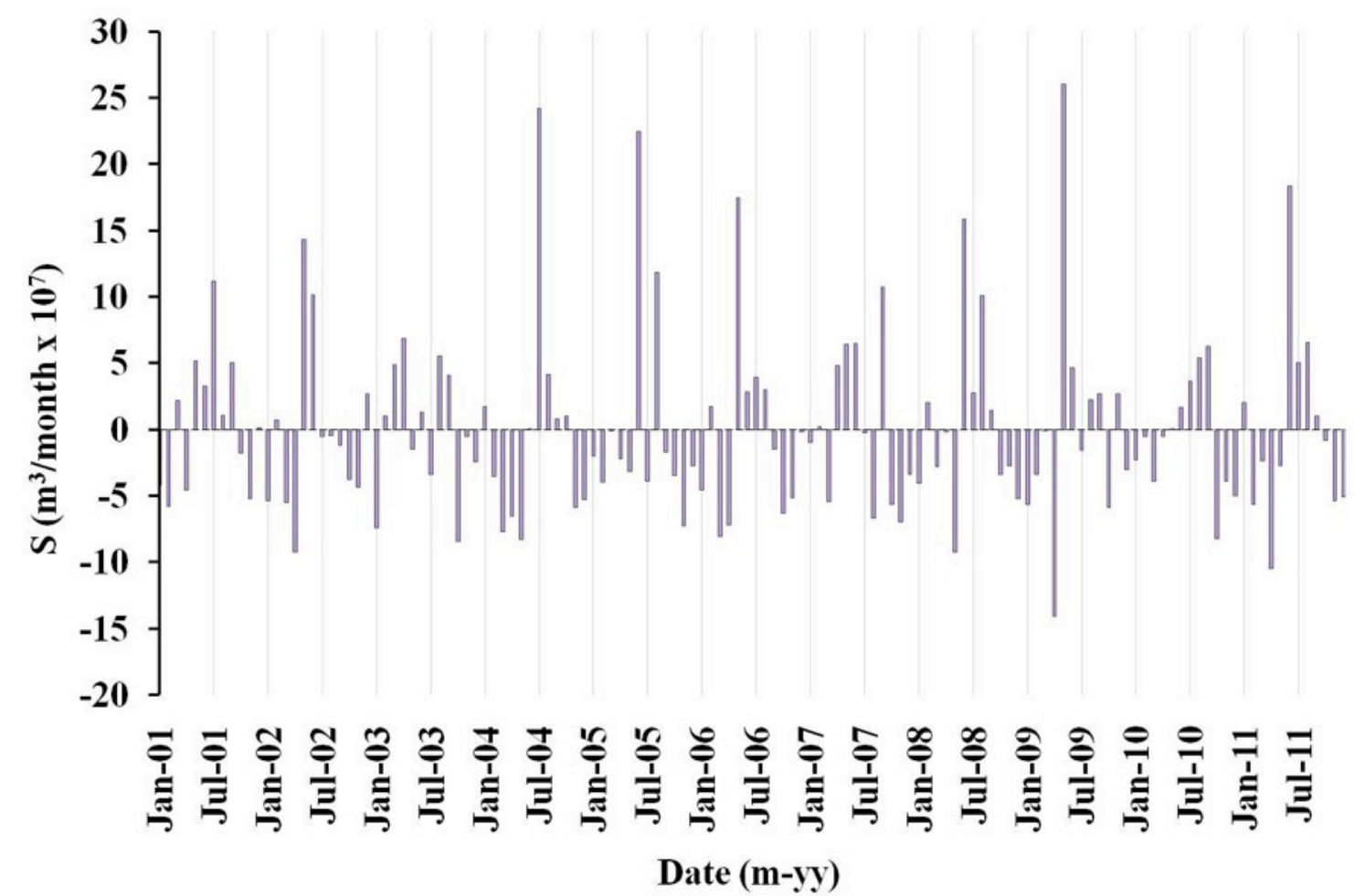

Figure 3.25. Monthly change in storage (S) values for southern Taylor Slough for January 2001 - December 2011.

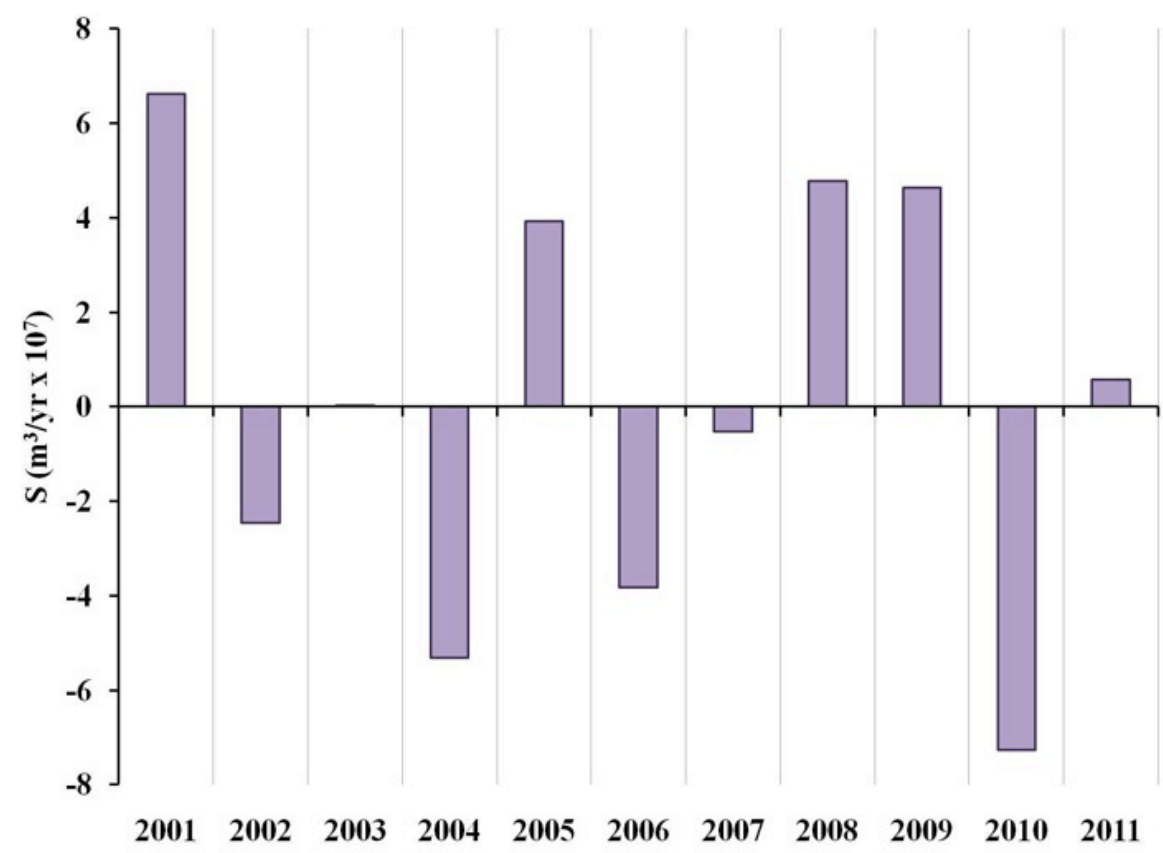

Figure 3.26. Yearly total sums of change in storage for southern Taylor Slough for 2001 $-2011$. 
Groundwater $(G W)$

From 2001 - 2011, the month of May had the highest average $G W$ value of $2.92 \mathrm{x}$ $10^{7} \mathrm{~m}^{3} /$ month and October had the lowest average $G W$ value of $-2.69 \times 10^{7} \mathrm{~m}^{3} / \mathrm{month}$ (Figure 3.24). The highest $G W$-value occurred in May 2002 with a value of $4.71 \times 10^{7}$ $\mathrm{m}^{3} /$ month, with the lowest $G W$ occurring in August 2001 with a value of --9.55 x $10^{7}$ $\mathrm{m}^{3} /$ month (Figure 3.27 ). The highest total yearly sum for groundwater was observed in 2004 with a positive value of $1.43 \times 10^{8} \mathrm{~m}^{3} /$ month. The lowest total yearly sum for the residual was observed in 2001 with a negative value of $-1.31 \times 10^{8} \mathrm{~m}^{3} / \mathrm{month}$ (Figure $3.28)$.

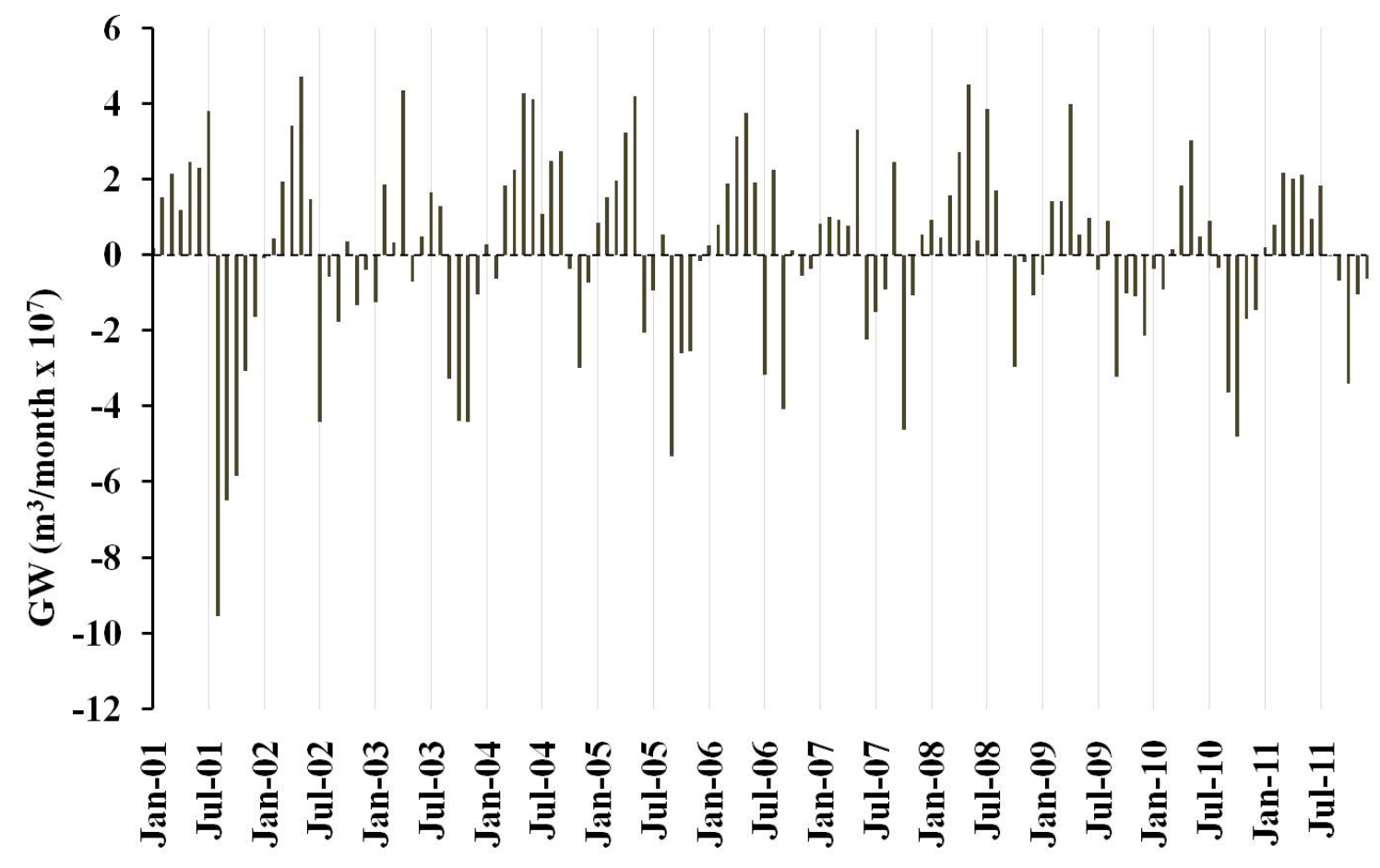

Date (m-yy)

Figure 3.27. Monthly groundwater (GW) values for southern Taylor Slough from January 2001 - December 2011. Positive GW values indicate groundwater discharging into Taylor Slough while negative GW values indicate Taylor Slough surface water is recharging the groundwater. 


\section{Precipitation Ratios}

The relationship of surface water inflow through TSB and precipitation showed a seasonal variability throughout the ten-year time scale. The ratio typically increased in June, peaking in December, and decreasing through March/April (Figure 3.29). On average, discharge into TSB during the months of April and May were either values close to zero or zero resulting in the ratio to be zero or very low between April and May. December 2008 had the highest ratio of 215.41 during the ten-year study (Figure 3.30). Cumulative surface water inflow at TSB and cumulative rain at TSB for January 2001 December 2011 had an overall slope of 5.46 .

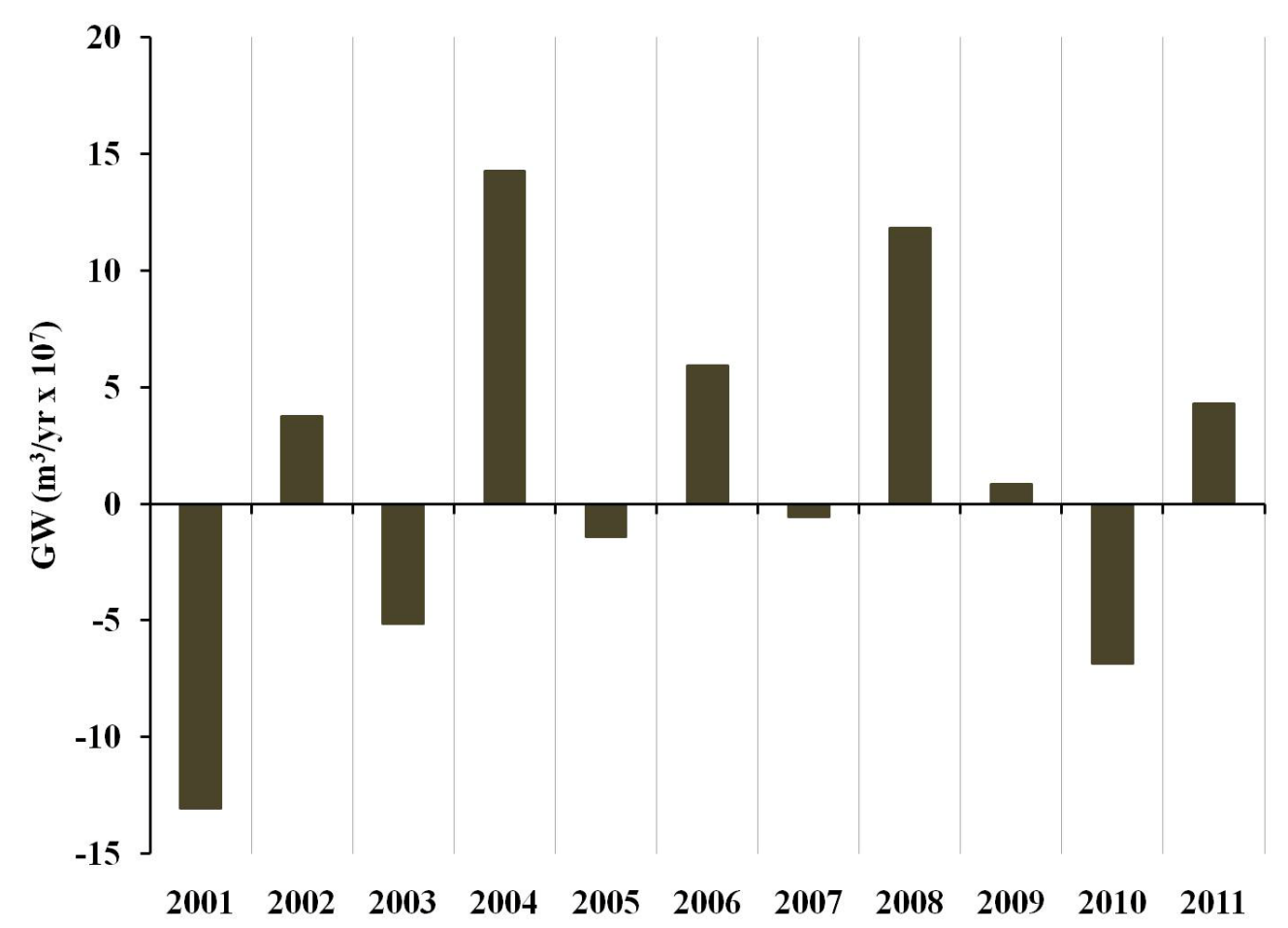

Figure 3.28. Total yearly sums of groundwater $(\mathrm{GW})$ for southern Taylor Slough from $2001-2011$.

Cumulative surface water inflow at TSB and cumulative rain at Royal Palm Station (RPL) had an overall slope of 5.16 (Figure 3.31). Between the months of October 
2005 and September 2008, the slope of the relationship of surface water inflow through TSB and precipitation decreased to 2.09. Surface water inflow at TSB was positively correlated with the total sum of the managed water inputs via the S332 discharge $\left(\mathrm{R}^{2}=\right.$ 0.6024; $\mathrm{p}<0.05$ ) (Figure 3.32). Surface water inflow at TSB had a weak but significant correlation with precipitation data from TSB $\left(\mathrm{R}^{2}=0.1909 ; \mathrm{p}<0.05\right)$ (Figure 3.33).

The ratio of surface water outflow and precipitation showed the highest average absolute value from $2001-2011$ in November with a ratio of 1.14 and June had the lowest average absolute value at 0.11 (Figure 3.34).

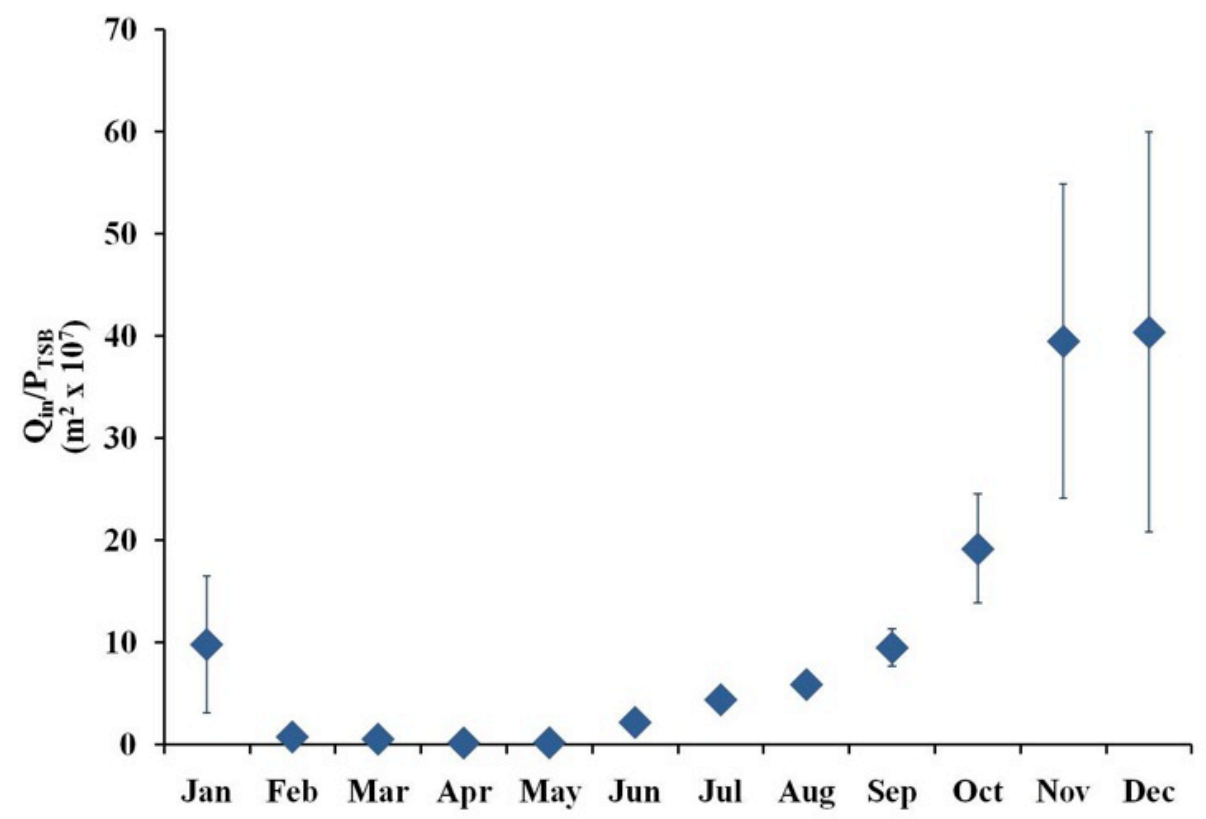

Figure 3.29. Monthly average of the surface water inflow at TSB and precipitation at TSB relationship ratio for $2001-2011$ with standard error bars. 


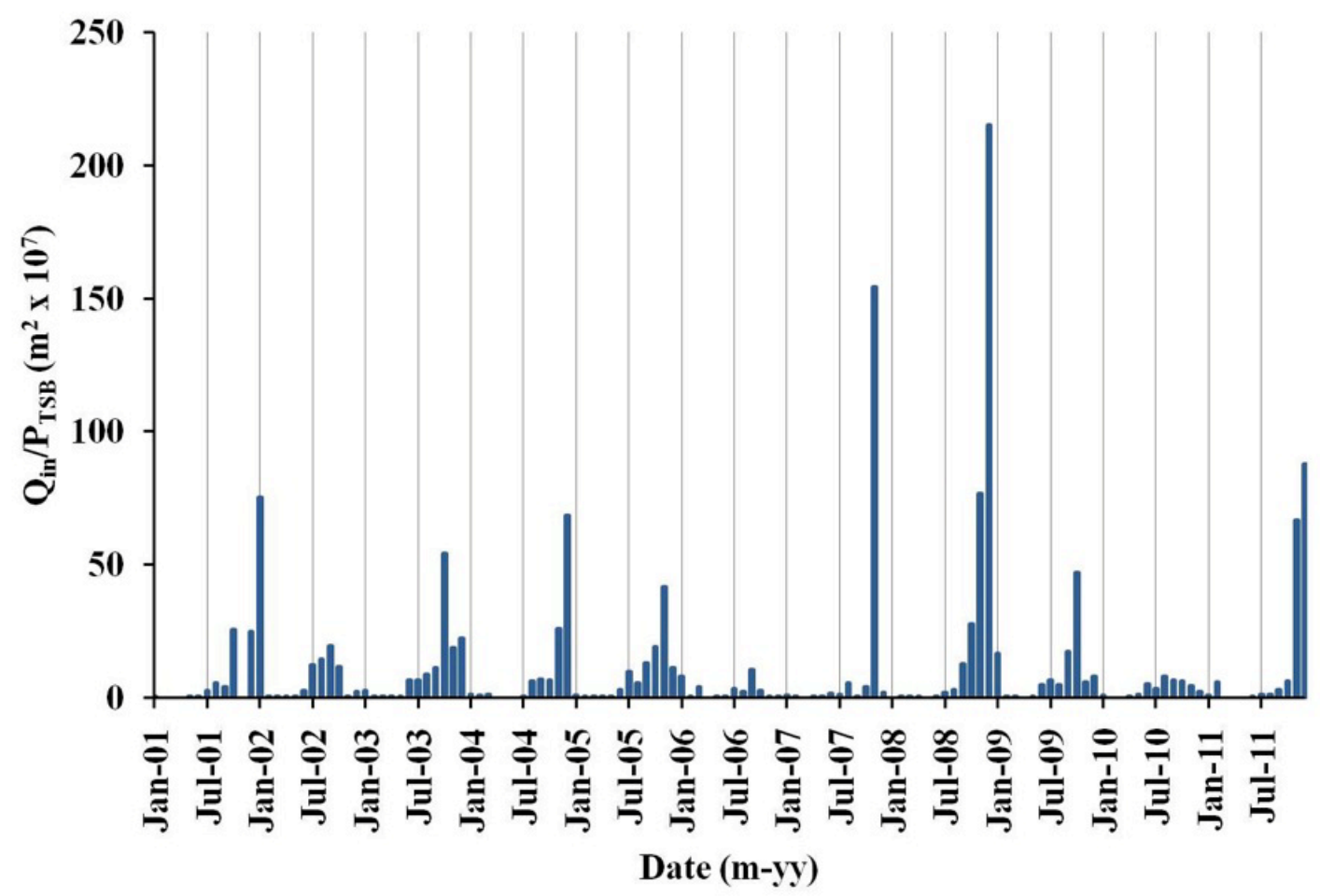

Figure 3.30. Monthly surface water inflow - precipitation at TSB ratio for January 2001 December 2011.

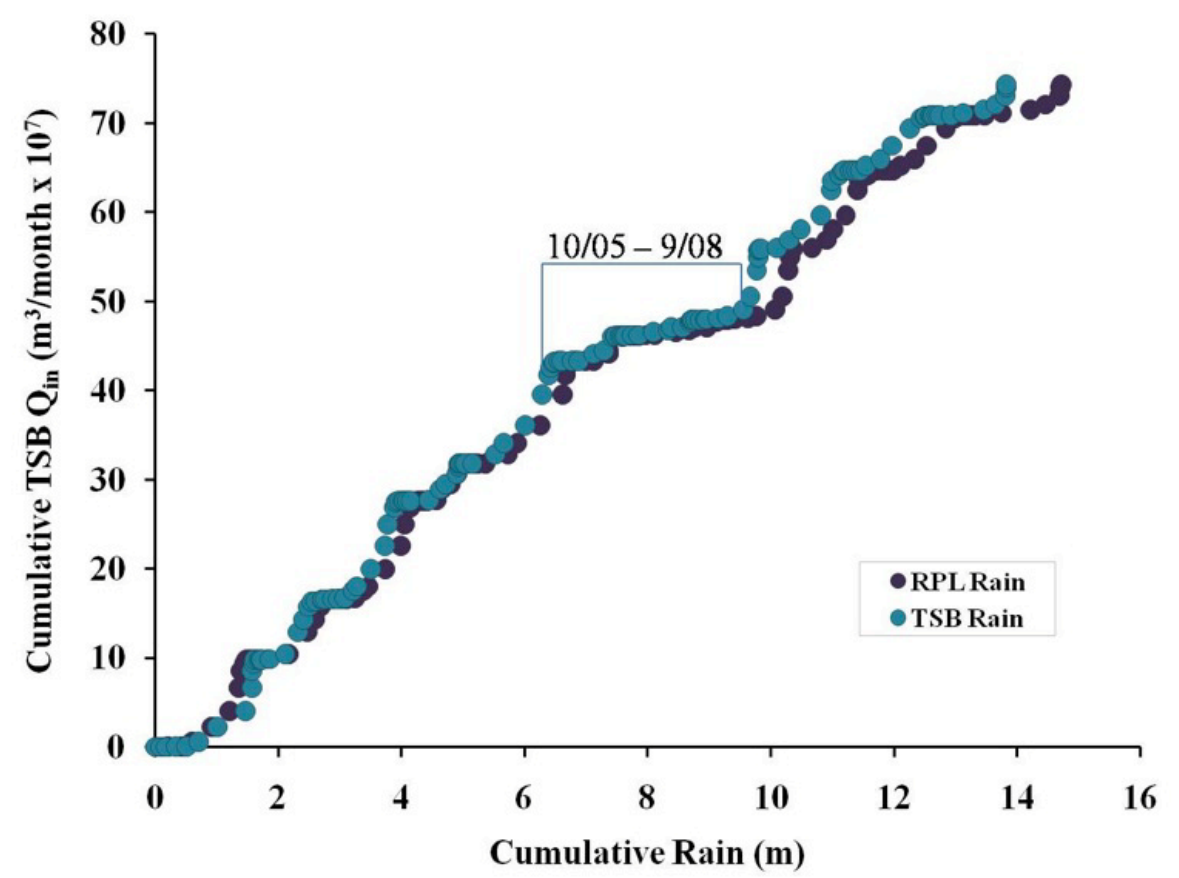

Figure 3.31. Cumulative rain vs. surface water inflow at TSB for January $2001-$ December 2011. Rain from TSB station (aqua) and Royal Palm Ranger Station (purple) are shown. 


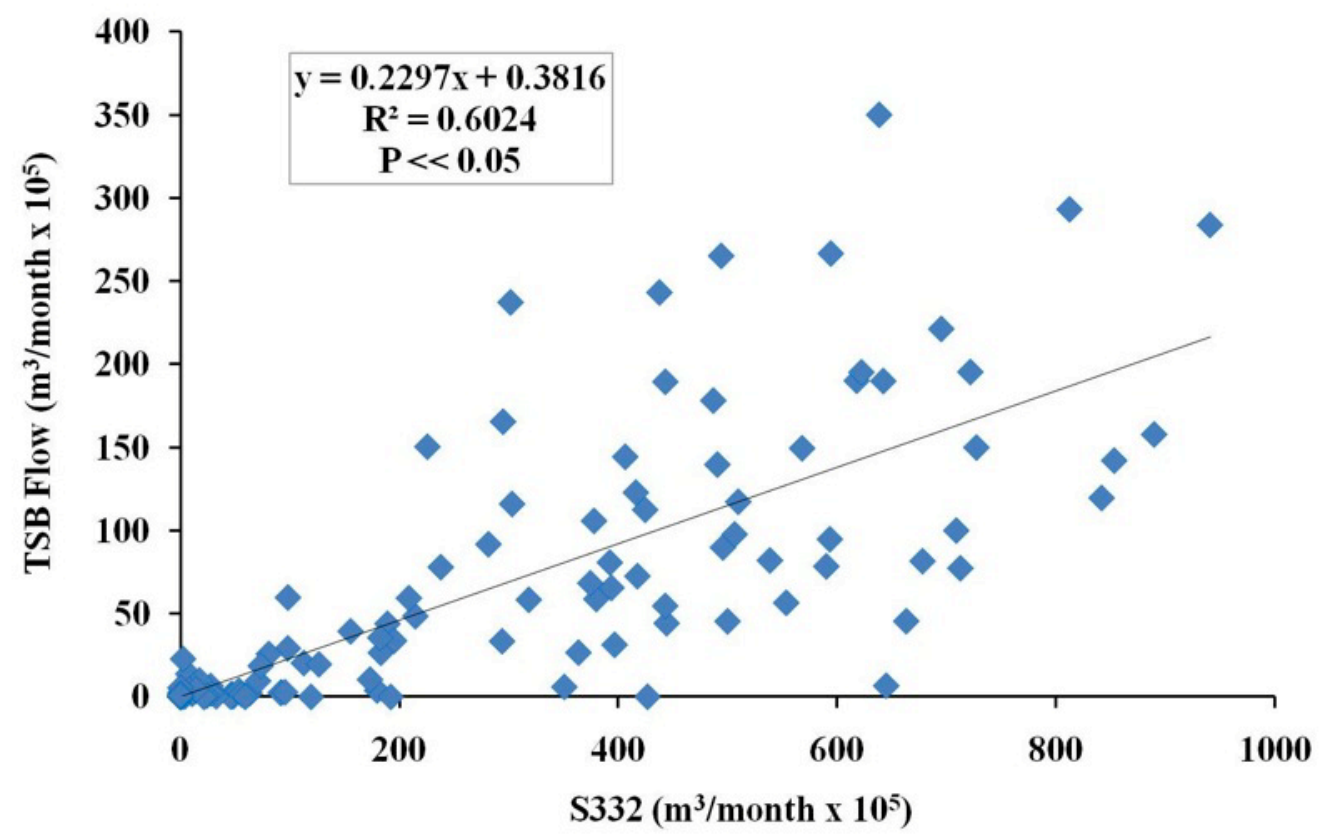

Figure 3.32. Surface water discharge at S332 vs. surface water discharge at TSB for January 2001 - December 2011.

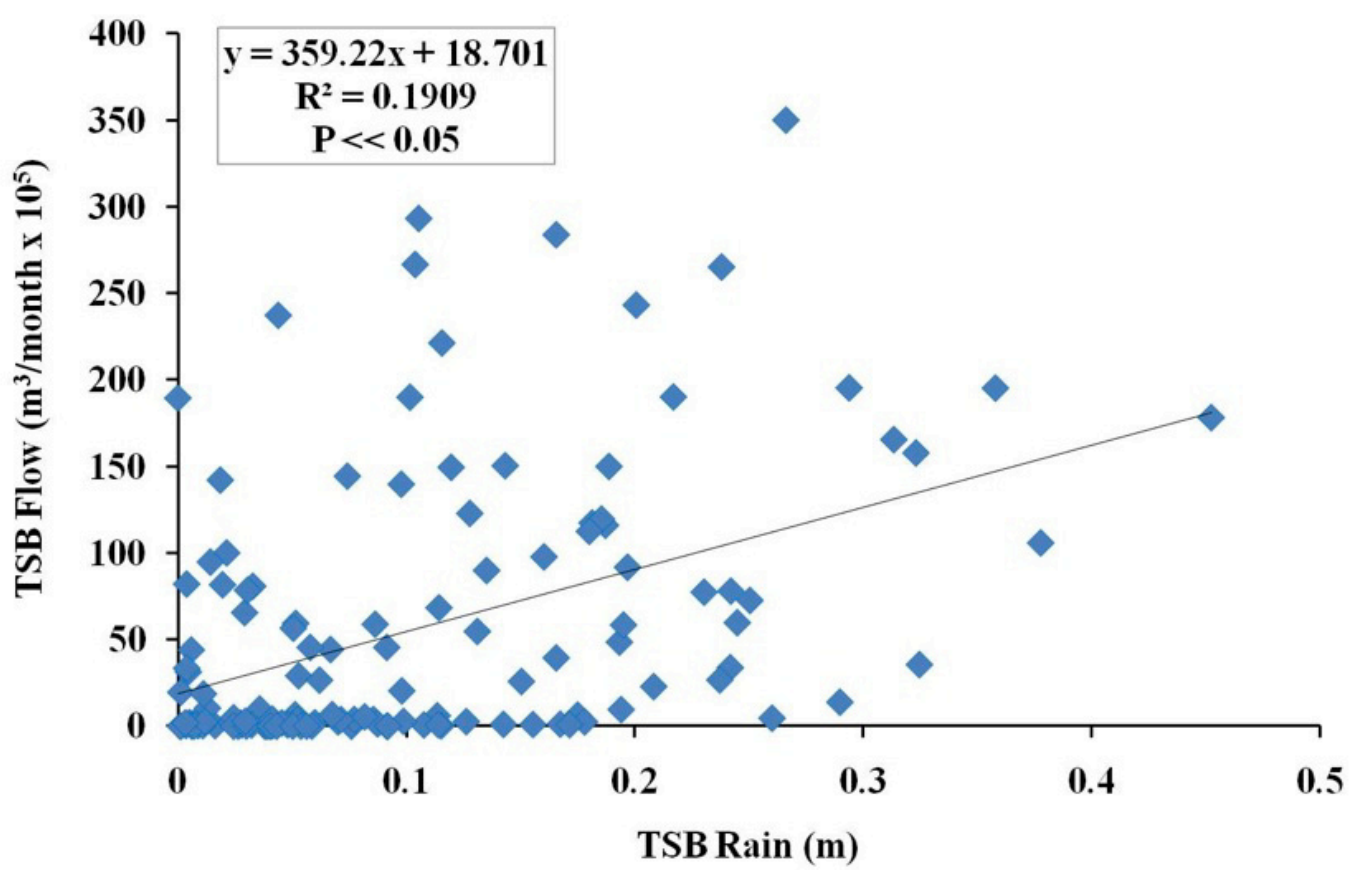

Figure 3.33. Rainfall at TSB vs. surface water discharge at TSB for January $2001-$ December 2011. 
January 2002 had the highest ratio of 6.41 during the ten year study period, while June 2008 had the lowest with a ratio of 0.0008 (Figure 3.35). Cumulative rain and cumulative surface water outflow from January 2001 - December 2011 had a slope of 0.198(Figure 3.36). The comparison between $\mathrm{Q}_{\text {out }}$ and precipitation had an R-squared value of $0.229(\mathrm{p}<0.05)$ (Figure 3.37). The relationship of change in storage and precipitation showed the highest average absolute values from 2001 - 2011 in January with a ratio of 5.38, and the lowest in September with a ratio of 0.31 (Figure 3.38). January 2002 had the highest ratio of 21.4 during the ten-year study, while August 2001 had the lowest ratio of 0.02 (Figure 3.39). The lower values were observed from the months of May to September with an increase beginning on October, peaking in January, and decreasing through May. The comparison between change in storage with precipitation had an $\mathrm{R}^{2}$ value of $0.527(\mathrm{p}<0.05)$ (Figure 3.40). 


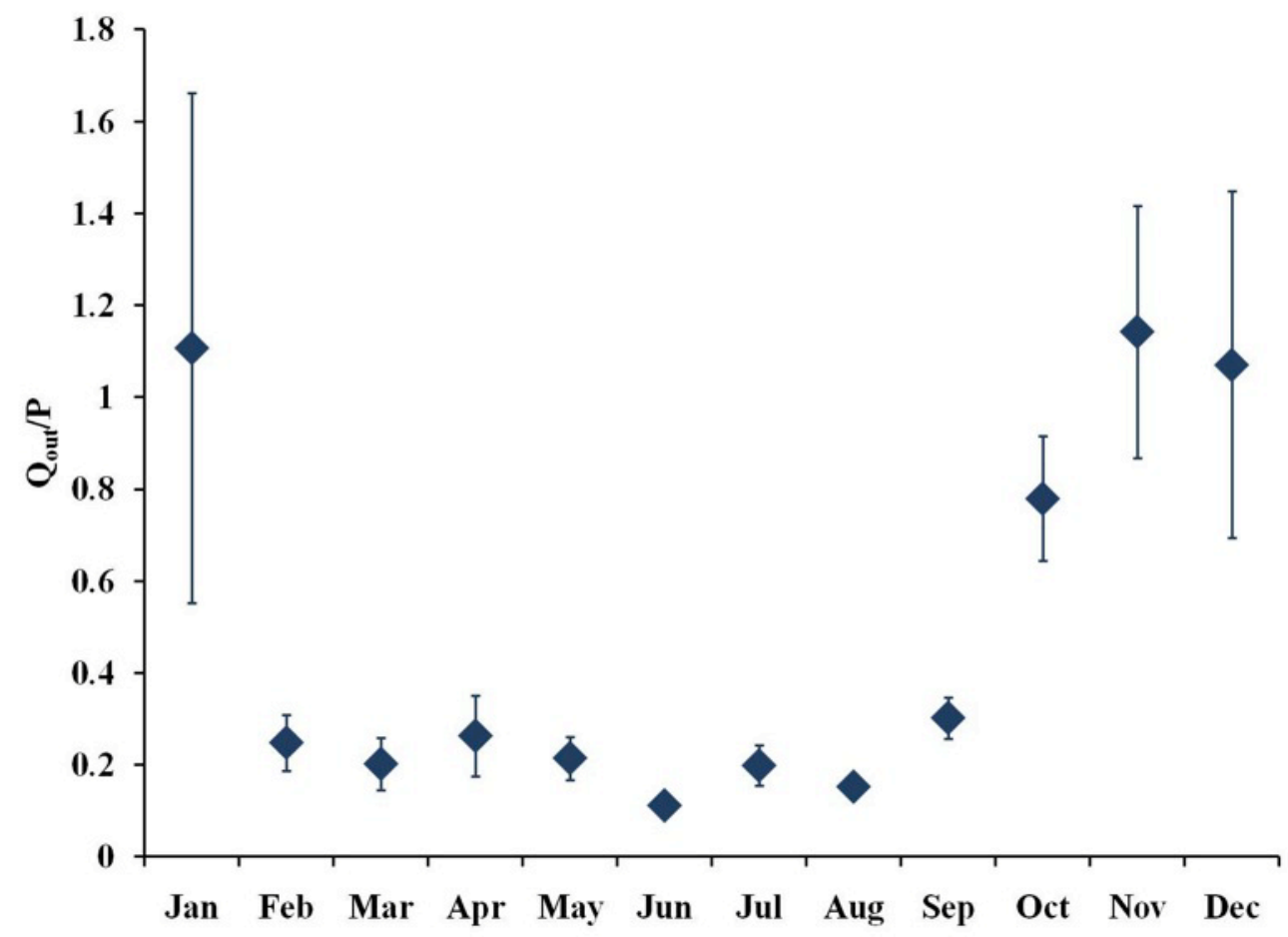

Figure 3.34. Monthly surface water outflow - precipitation ratio (absolute value) for January 2001 - December 2011.

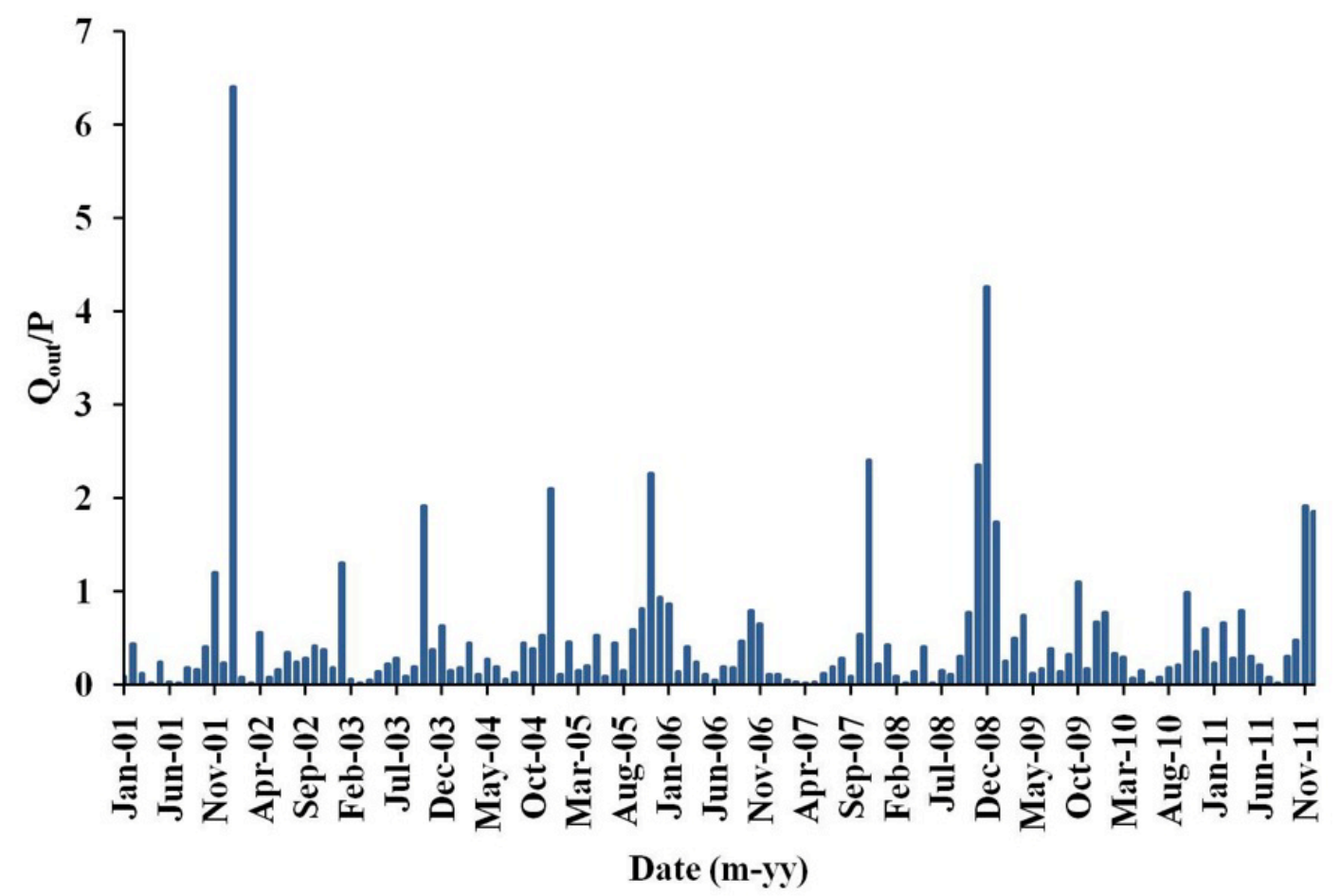

Figure 3.35. Monthly surface water outflow - precipitation ratio for January 2001 December 2011. 


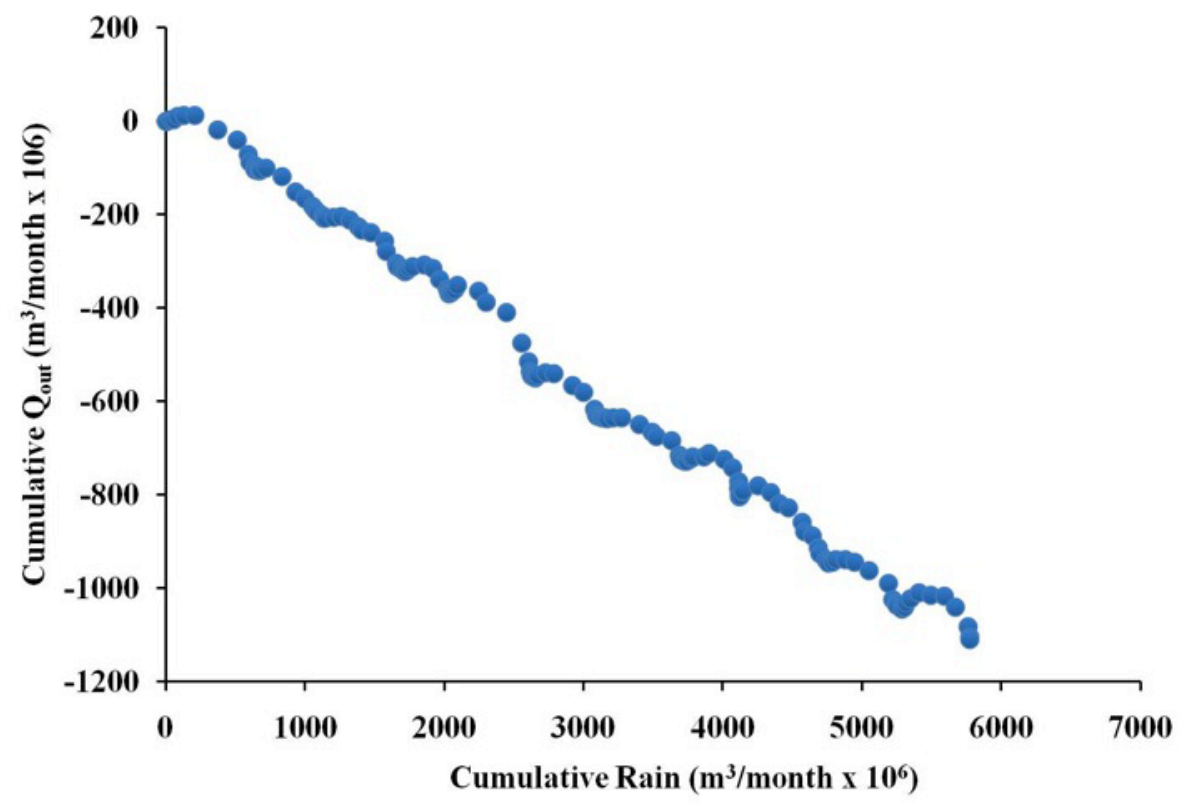

Figure 3.36. Cumulative rain vs. surface water outflow for January 2001 - December 2011.

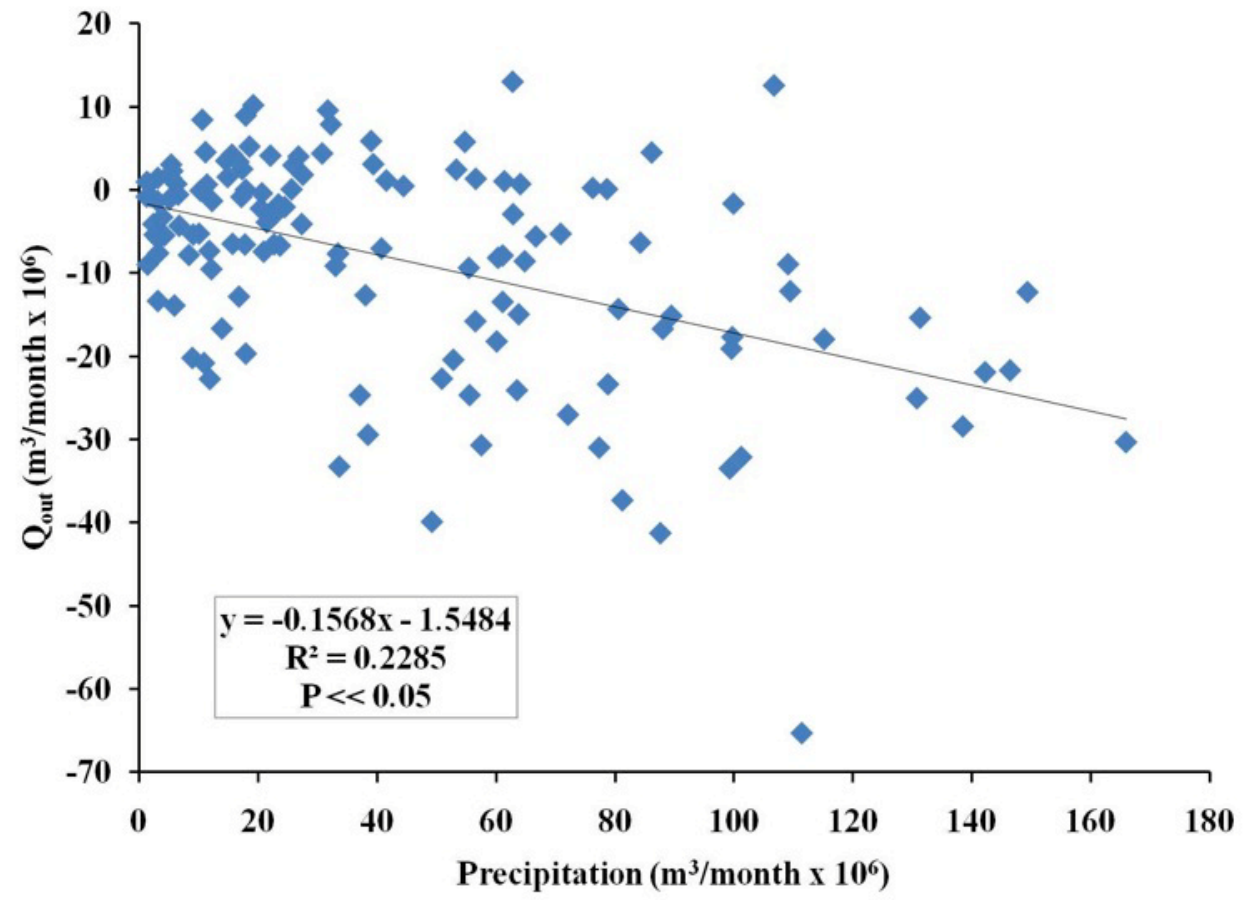

Figure 3.37. Surface water outflow vs. Precipitation for southern Taylor Slough for January 2001 - December 2011. 


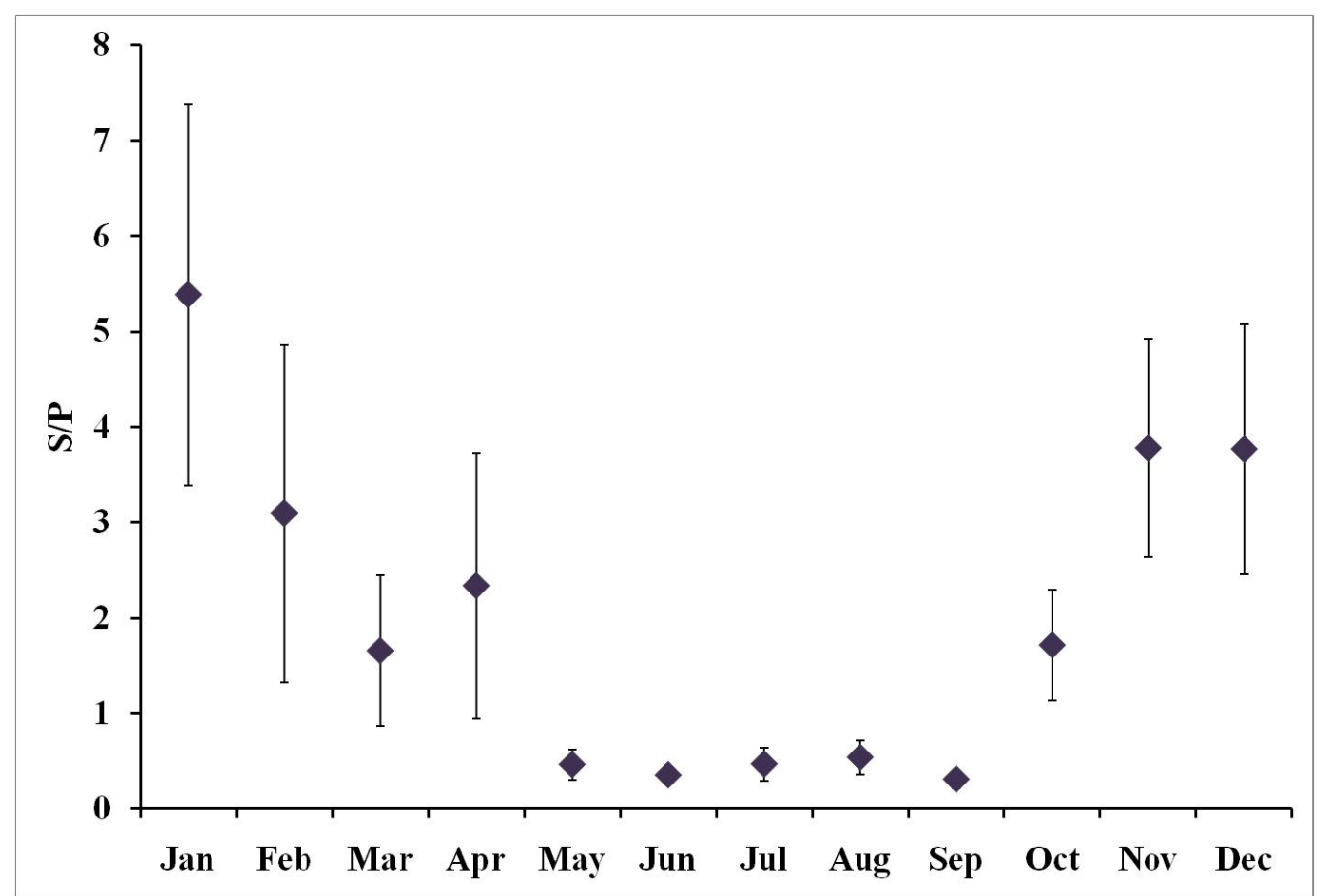

Figure 3.38. Monthly change in storage - precipitation ratio (absolute value) for January 2001 - December 2011.

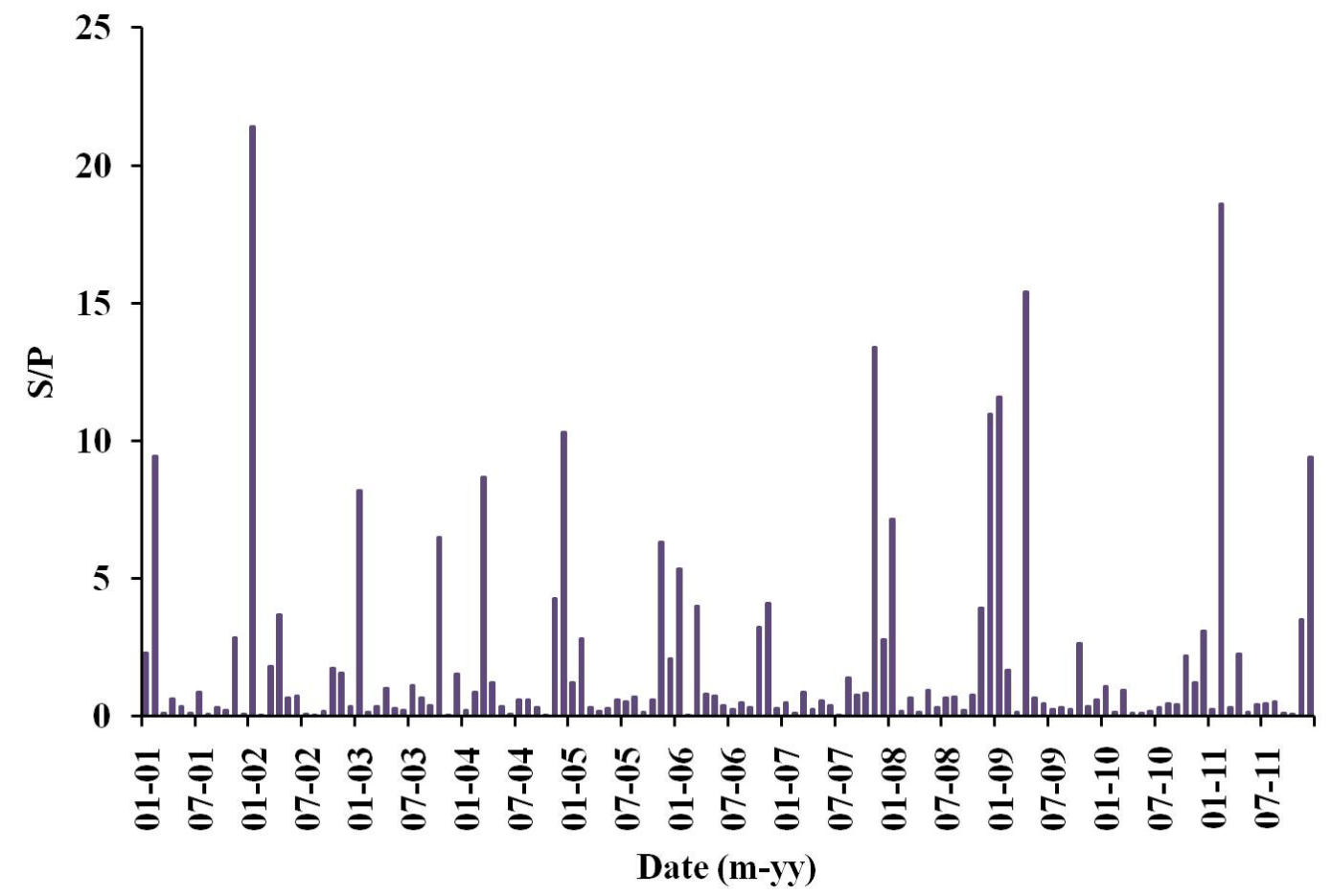

Figure 3.39. Monthly Change in storage vs. Precipitation for southern Taylor Slough for January 2001 - December 2011. 


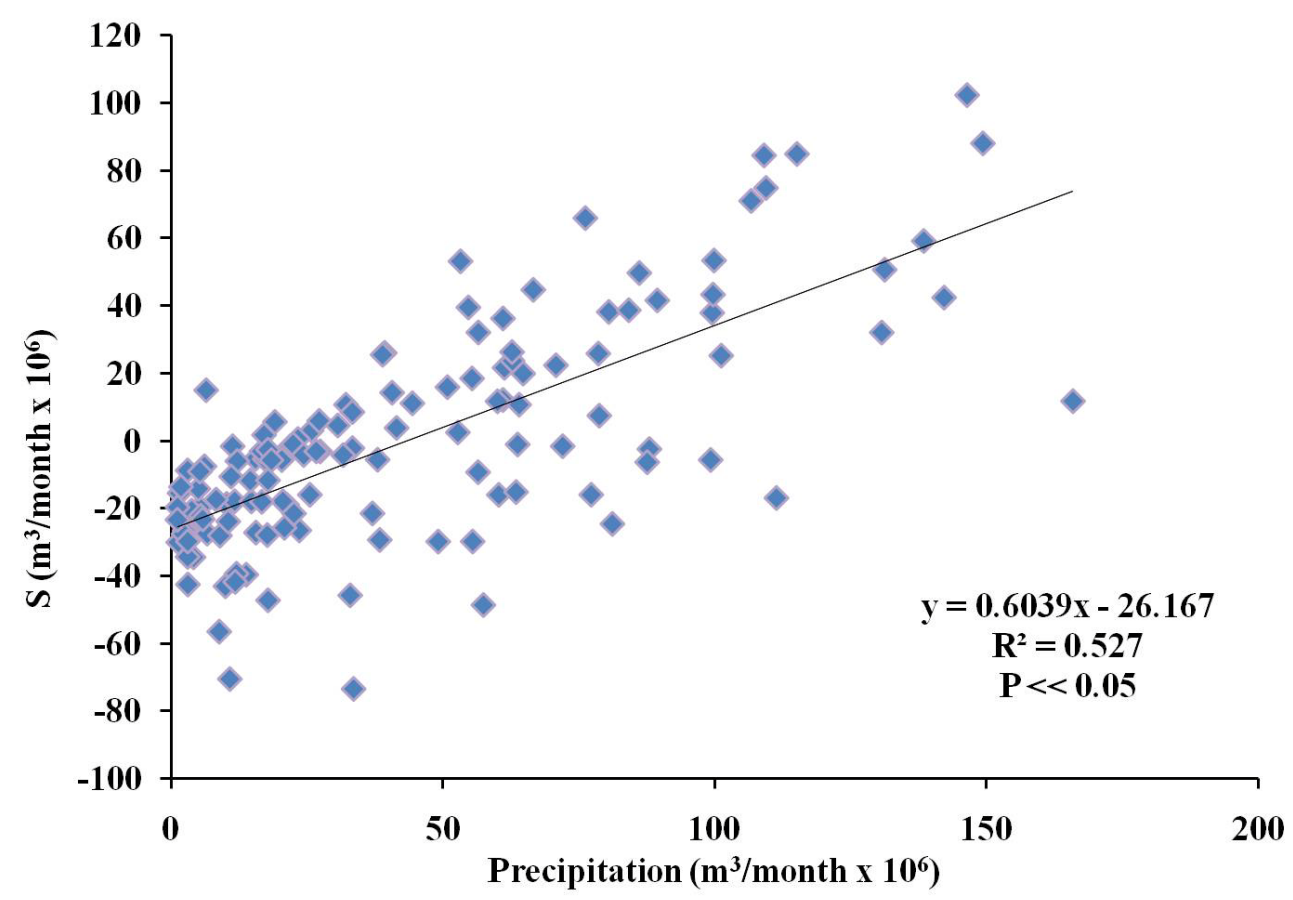

Figure 3.40. Change in storage vs. Precipitation for southern Taylor Slough for January 2001 - December 2011.

\section{CHEMICAL ANALYSIS}

Freshwater Sites

Water ion concentrations for the freshwater sites tended to decrease from north to south (from TS/Ph-1 to TS/Ph-3) (Figure 3.41) except during the months of February through June, when sodium (Fig. 3.41A), potassium (Fig. 3.41B) and chloride (Fig. 3.42A) concentrations at TS/Ph-3 increased above those observed at the northern TS/Ph-2 site, and tended to peak between March and May. There were gaps in the available data, particularly for $\mathrm{TS} / \mathrm{Ph}-1$, because during the dry season, surface water was not present. Sulfate values at TS/Ph-2 peaked, on average, in May at 0.065 meq $/ \mathrm{L}$ while TS/Ph-3 peaked, on average, in July at $0.043 \mathrm{meq} / \mathrm{L}$ (Fig. 3.42B). Total Nitrogen (TN) values for 
freshwater sites from 2003 - 2010 increased in average concentrations from TS/Ph-1 south to TS/Ph-3 except during the months of October through December where the gradient was reversed, with decreasing values from TS/Ph-1 to TS/Ph-3 (Fig. 3.43). Total Phosphorus (TP) average concentrations at TS/Ph-1 peaked in both January and October with an average value of $0.357 \mathrm{mg} / \mathrm{L}$ each month, while peak average TP values at TS/Ph-2 and TS/Ph-3 were observed in March with average values of $0.360 \mathrm{mg} / \mathrm{L}$ and $0.341 \mathrm{mg} / \mathrm{L}$ respectively (Fig. 3.44). 


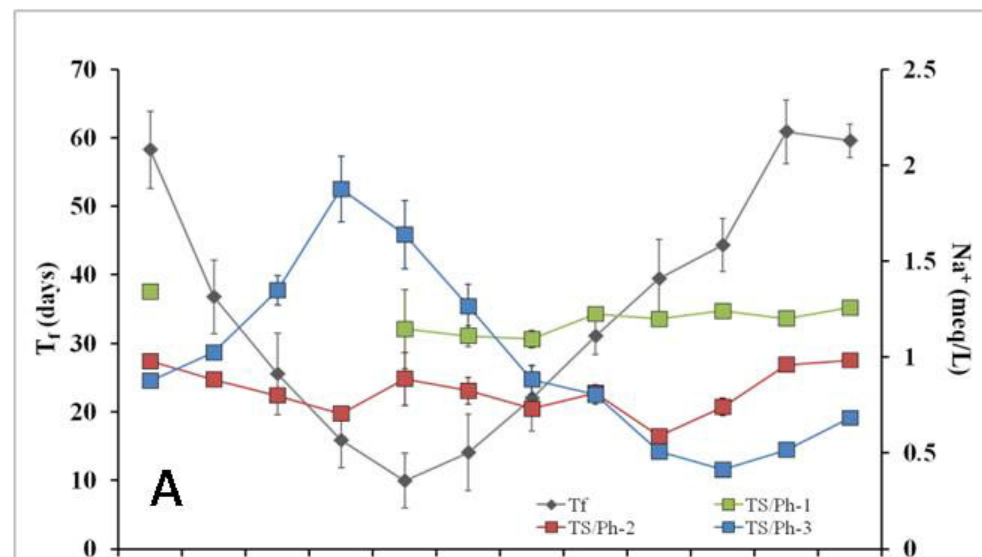

Jan Feb Mar Apr May Jun Jul Aug Sep Oct Nov Dec

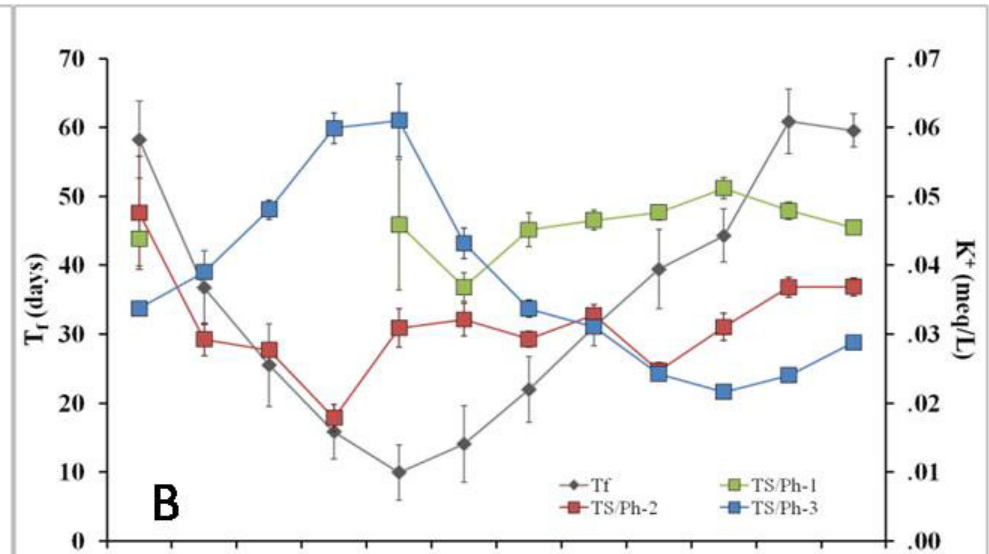

Jan Feb Mar Apr May Jun Jul Aug Sep Oct Nov Dec
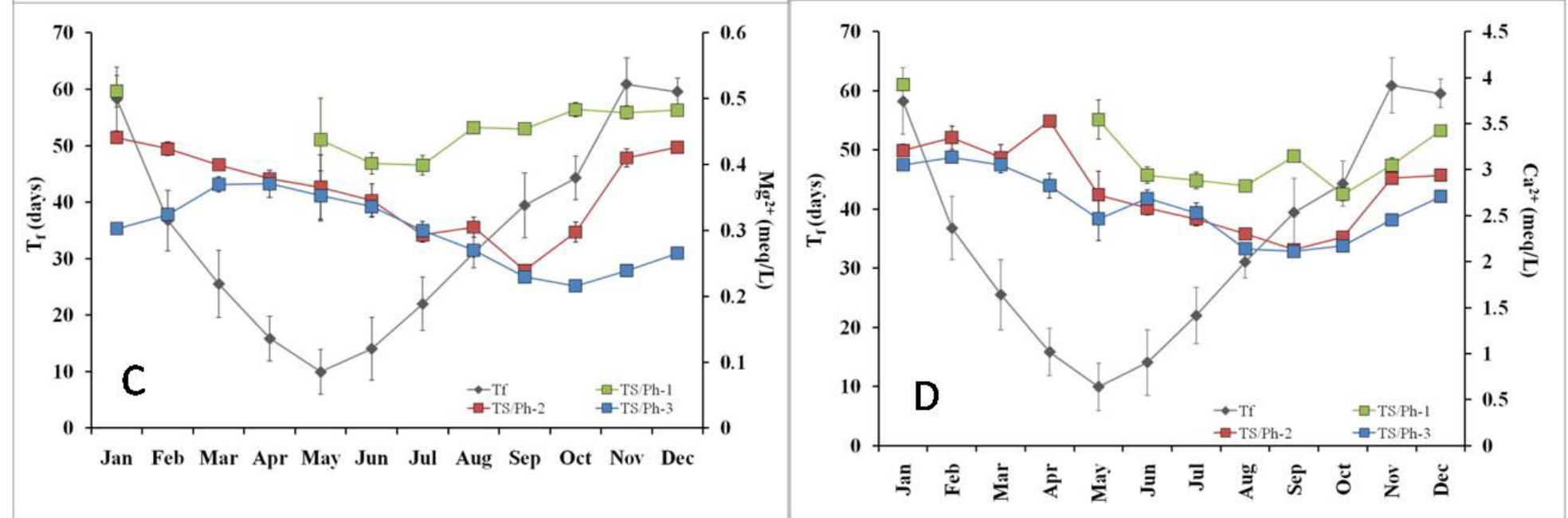

Figure 3.41. Monthly average surface water cation concentrations of (A)Sodium, (B) Potassium, (C) Magnesium, and (D)Calcium for the freshwater sites (TS/Ph-1, TS/Ph-2, and TS/Ph-3) of southern Taylor Slough with standard error bars. Data ranges from August 2008 to December 2011. Water flushing times (grey diamond) for August 2008 - December 2011 are also shown. 

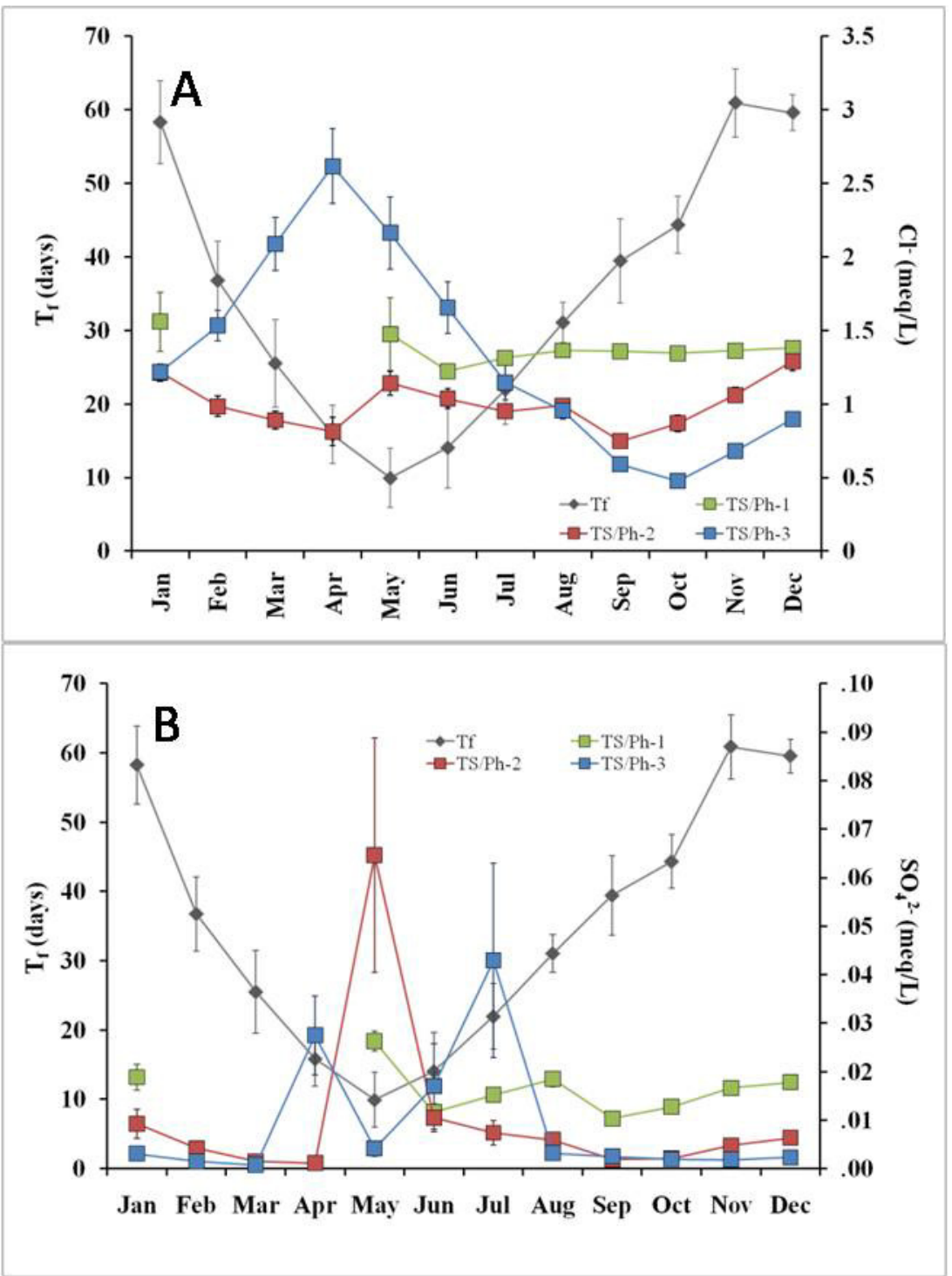

Figure 3.42. Monthly average surface water anion concentrations of (A) chloride and (B) sulfate for freshwater sites (TS/Ph-1, TS/Ph-2, and TS/Ph-3) of southern Taylor Slough with standard error bars. Sulfate (B) values that were greater than the sulfate axis values are labeled with their values. Data ranges from August 2008 - December 2011. Water flushing times for August 2008 - December 2011 are also shown. 


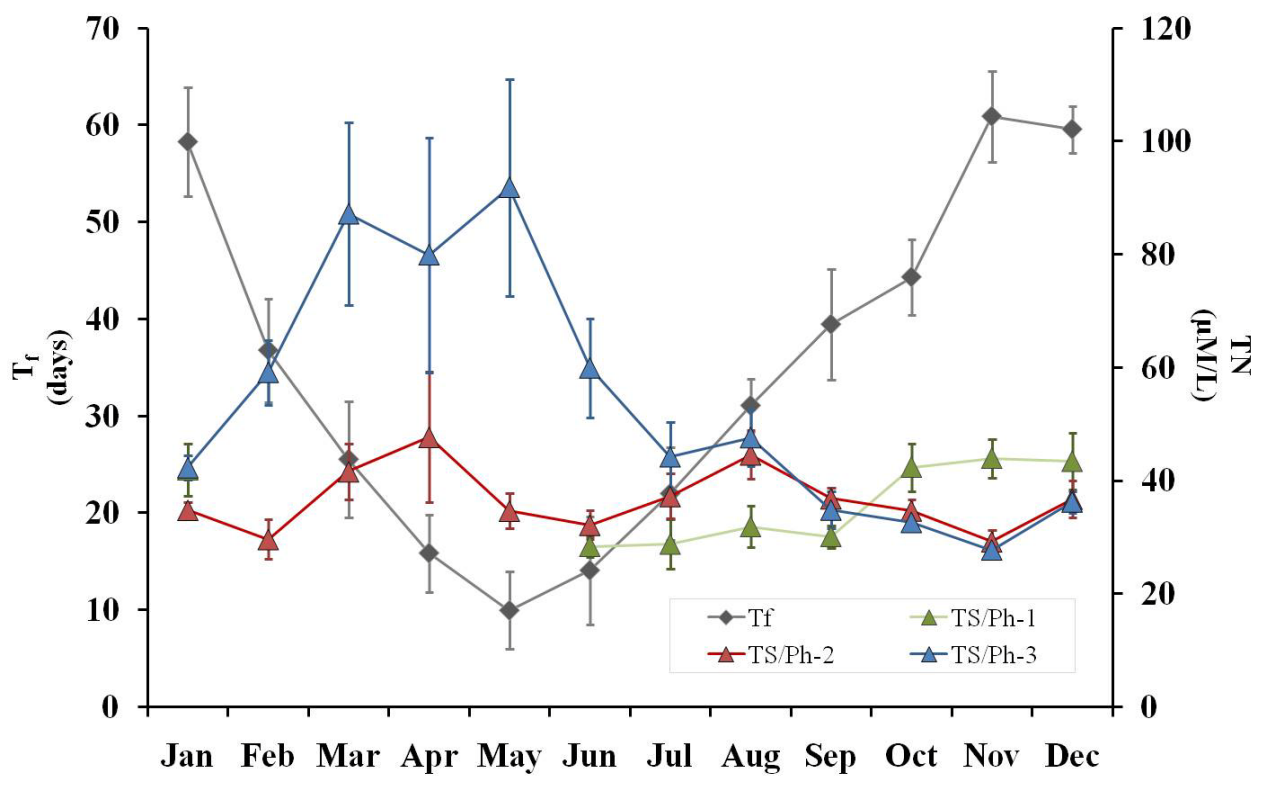

Figure 3.43. Monthly average Total Nitrogen (TN) for freshwater sites (TS/Ph-1, TS/Ph2, TS/Ph-3) in southern Taylor Slough for $2003-2011$. Monthly average flushing times are also shown.

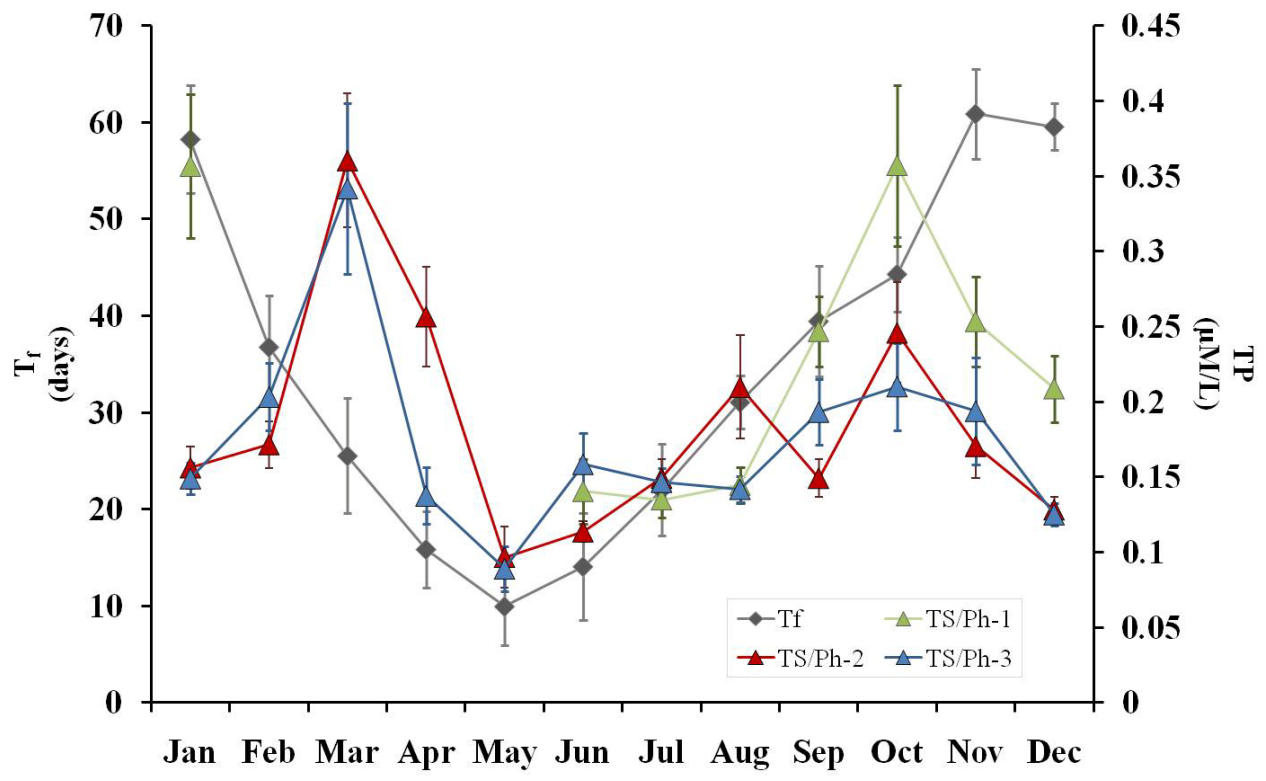

Figure 3.44. Monthly average Total Phosphorus (TP) for freshwater sites (TS/Ph-1, $\mathrm{TS} / \mathrm{Ph}-2$, and TS/Ph-3) in southern Taylor Slough for 2003 - 2011. Monthly average flushing times are also shown. 
Stable isotopes of oxygen and hydrogen for 2011 - 2012 for the freshwater sites all fell below the meteoric water line (Figure 3.45). Data of surface water and groundwater stable isotopes of oxygen and hydrogen for TSB from 1998-1999 and 20112012 had similar average values as data for TS/Ph-1 and TS/Ph-2 surface waters with values ranging between $-0.61 \%$ and $+0.45 \%$ for $\delta^{18} \mathrm{O}$ and $-0.32 \%$ and $+3.37 \%$ for $\delta \mathrm{D}$. Surface water average values for stable isotopes of oxygen and hydrogen at the centrally located TS/Ph-3 showed a positive trend from $1998 / 1998\left(\delta^{18} \mathrm{O}\right.$ average value of $-0.61 \%$, $\delta \mathrm{D}$ average value of $-0.32 \%$ ) to $2008 / 2009$ and $2011 / 2012$ with $\delta^{18} \mathrm{O}$ average values that ranged from $+0.57 \%$ to $+1.32 \%$ and $\delta \mathrm{D}$ average values that ranged between $+3.91 \%$ o to $+6.87 \%$. Groundwater average values for $\delta^{18} \mathrm{O}$ and $\delta \mathrm{D}$ at TS/Ph-3 showed a positive trend from the $1998 / 1999$ data $\left(-1.77 \%\right.$ for $\delta^{18} \mathrm{O},-7.32 \%$ for $\left.\delta \mathrm{D}\right)$ to $2008 / 2009(+0.22 \%$ o $\delta^{18} \mathrm{O},+2.41 \%$ oD) to $2011 / 2012\left(+0.86 \%\right.$ o $\delta^{18} \mathrm{O},+8.48 \%$ oD $)$.

\section{Coastal Sites}

Water ion concentrations at TS/Ph-7 were consistently higher than at TS/Ph-6 for cations and anions (Fig. 3.46, Fig. 3.47). TS/Ph-7 had rapid fluctuations in ion concentrations in a short timescale, but there was a seasonal variability that was also observed in $\mathrm{TS} / \mathrm{Ph}-6$. On average, ion concentrations at the two sites increased between February and May, peaking in June, and decreasing after June through January. Ion concentrations at the two sites were lowest between October and January. 


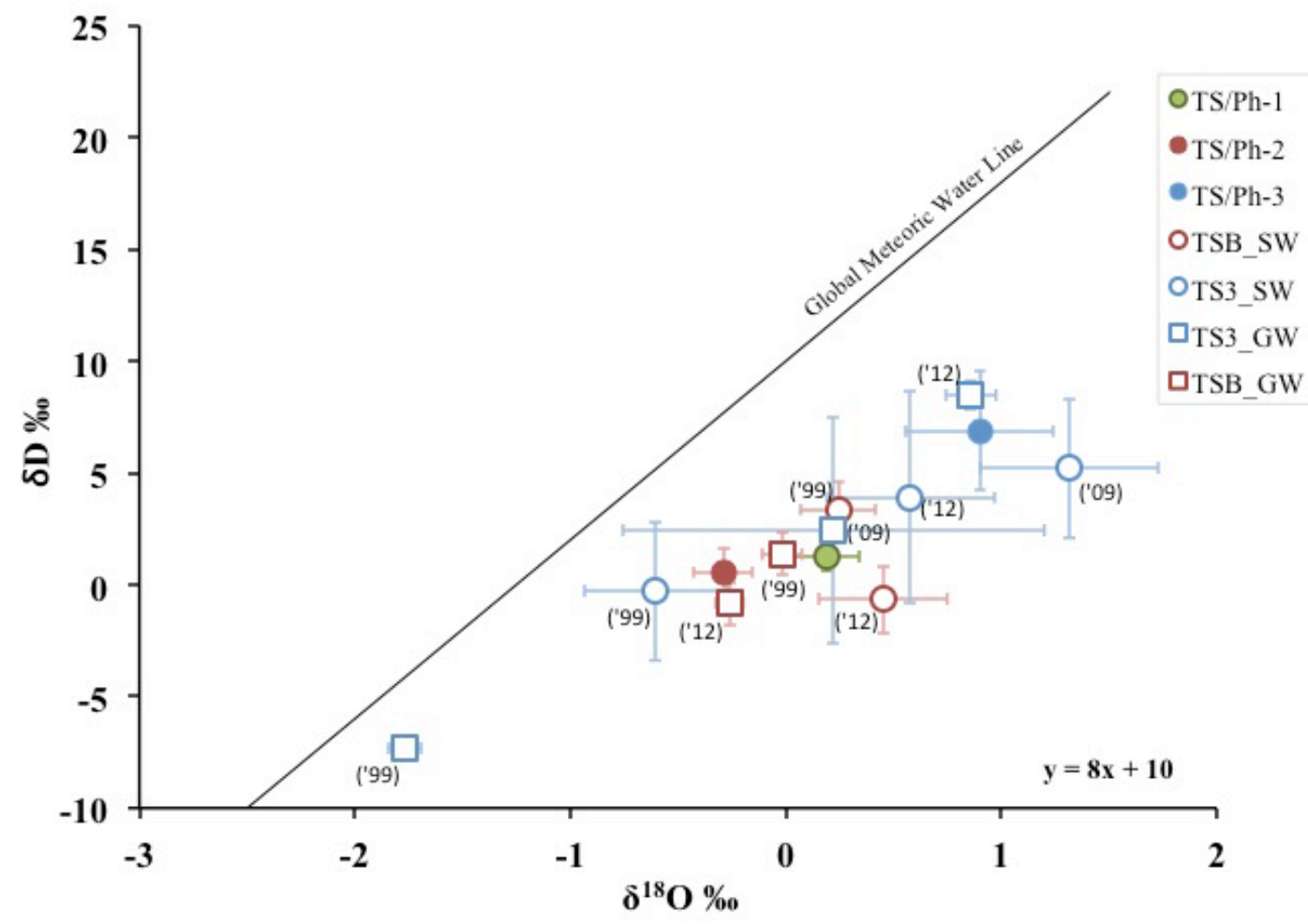

Figure 3.45. Average values of stable isotopes of oxygen and hydrogen for the freshwater sites (TSB, TS/Ph-1, TS/Ph-2, TS/Ph-3) spanning from 1998/1999 to 2012 with standard error bars. Slope for the global meteoric water line is $y=8 x+10$. 

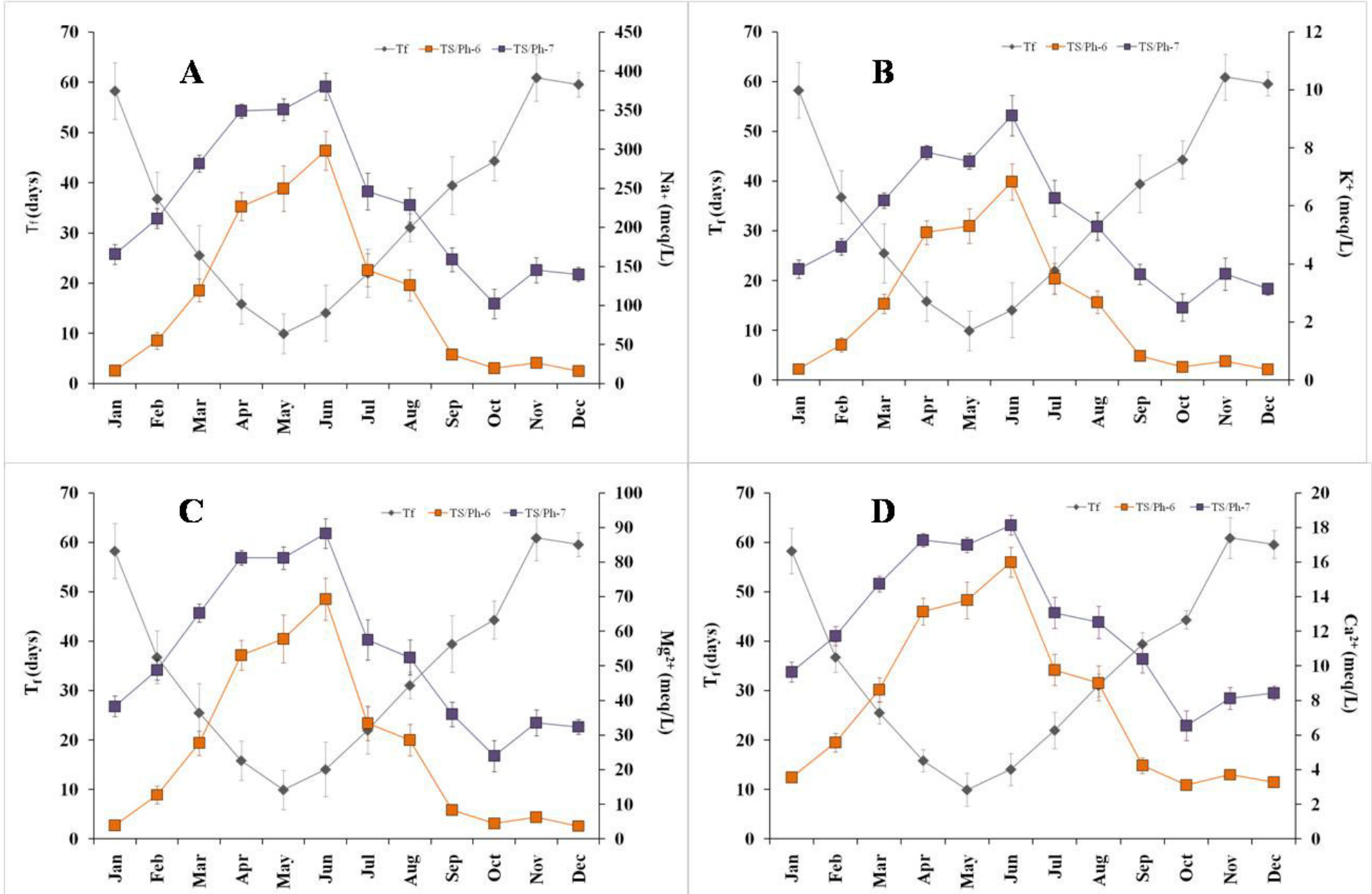

Figure 3.46. Monthly average surface water cation concentrations of (A)Sodium, (B) Potassium, (C) Magnesium, and (D)Calcium for the coastal sites (TS/Ph-6 and TS/Ph-7) of southern Taylor Slough with standard error bars. Data ranges from January 2008 to December 2011. 

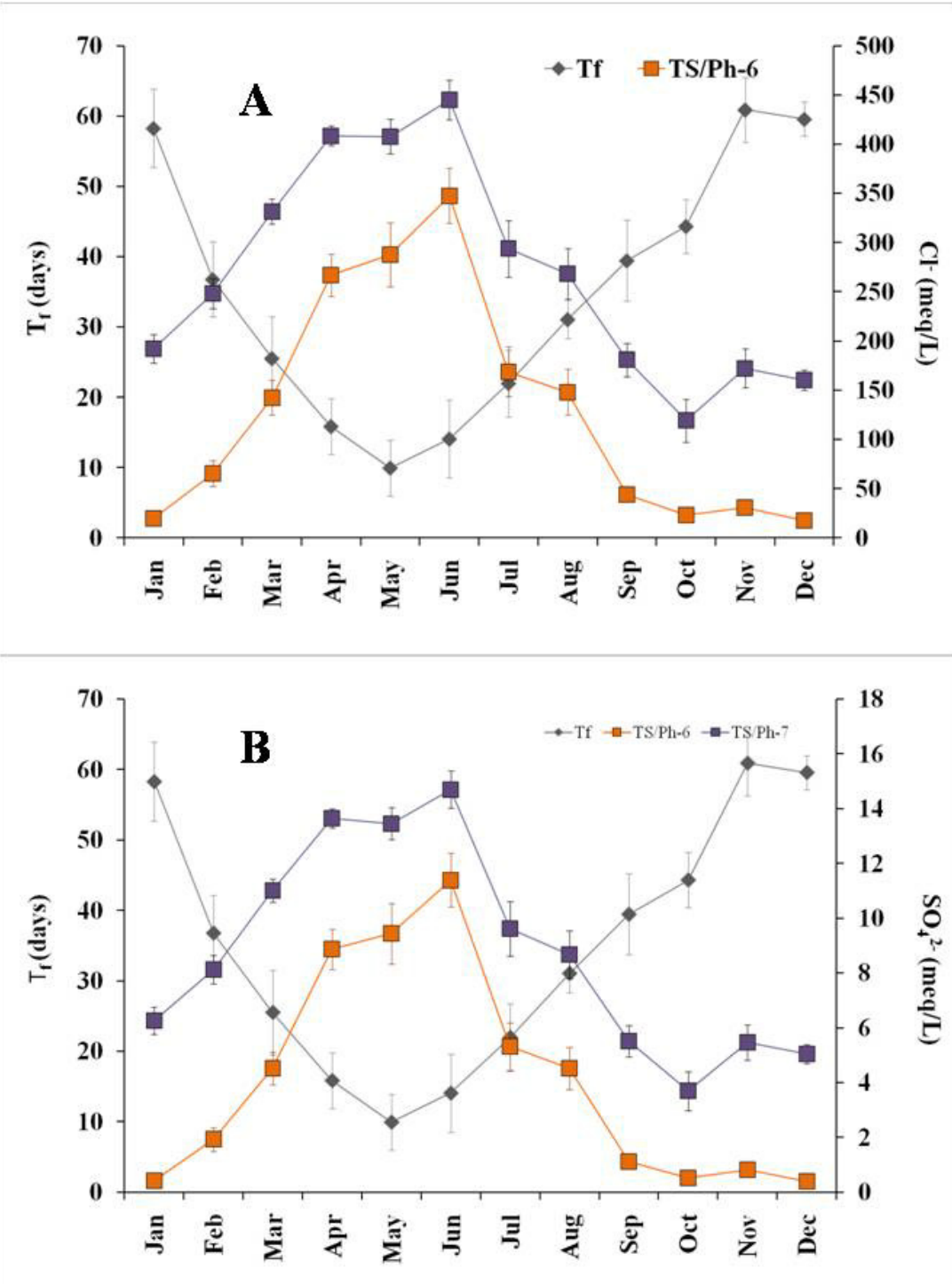

Figure 3.47. Monthly average surface water anion concentrations of (A) chloride and (B) sulfate for the coastal sites (TS/Ph-6 and TS/Ph-7) in southern Taylor Slough with standard error bars.

Both TN and TP for TS/Ph-6 and TS/Ph-7 were available for the period of $2001-$ 2010. For TN, the two sites had similar monthly average values and had the same trend (Fig. 3.48). The two sites had peak average TN values in March with TS/Ph-6 average value at $68.94 \mathrm{mg} / \mathrm{L}$ and TS/Ph-7 average value at $71.40 \mathrm{mg} / \mathrm{L}$. Total Phosphorus for 
TS/Ph-6 average monthly values stayed relatively consistent between $0.250 \mathrm{mg} / \mathrm{L}$ and $0.327 \mathrm{mg} / \mathrm{L}$ during the months of July through February (Fig. 3.49). Average monthly values for TP at TS/Ph-6 increased to $0.528 \mathrm{mg} / \mathrm{L}$ in March, peaked at $0.626 \mathrm{mg} / \mathrm{L}$ in April, and decreased to $0.464 \mathrm{mg} / \mathrm{L}$ in June. Average monthly values for TP at TS/Ph-7 stayed relatively consistent throughout the months, with a peak average monthly value of $0.375 \mathrm{mg} / \mathrm{L}$ in the month of March and lowest average monthly value of $0.234 \mathrm{mg} / \mathrm{L}$ in October.

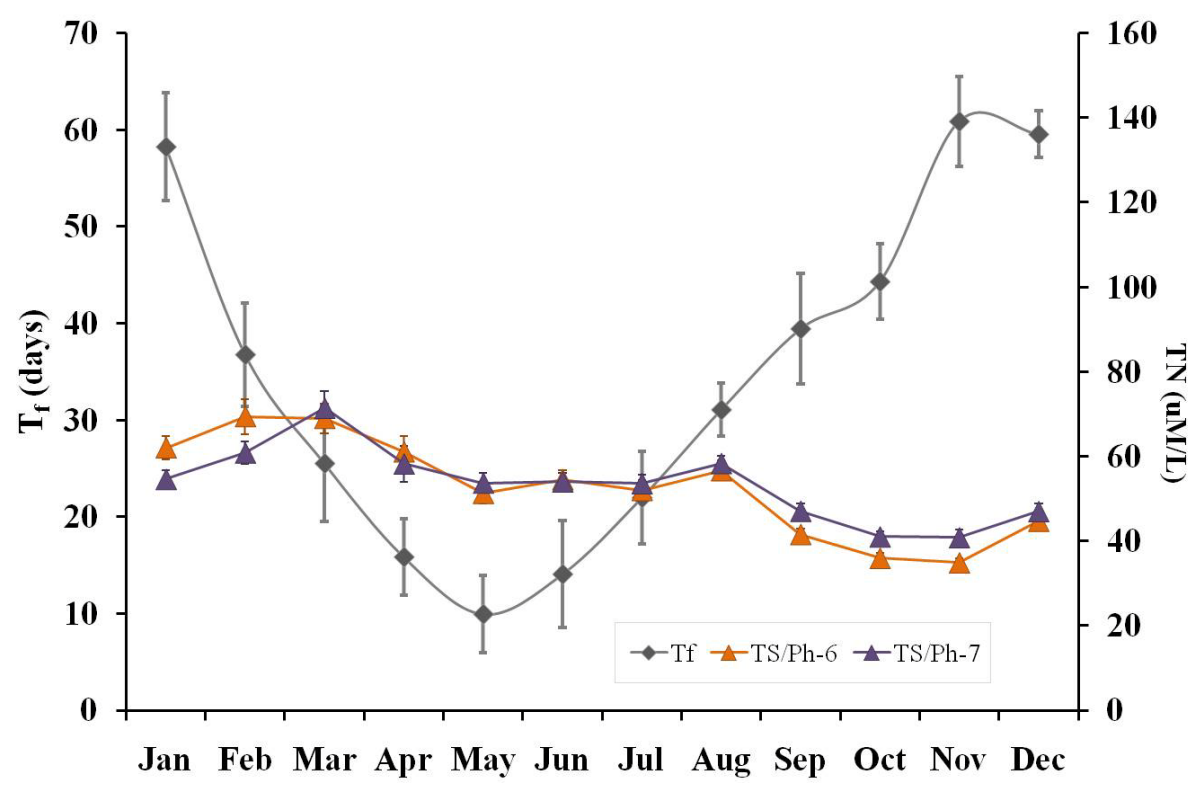

Figure 3.48. Monthly average Total Nitrogen of the coastal sites (TS/Ph-6 and TS/Ph-7) of southern Taylor Slough from 2001 - 2010 with standard error bars. Water flushing times (blu diamond) are also graphed with standard error bars. 


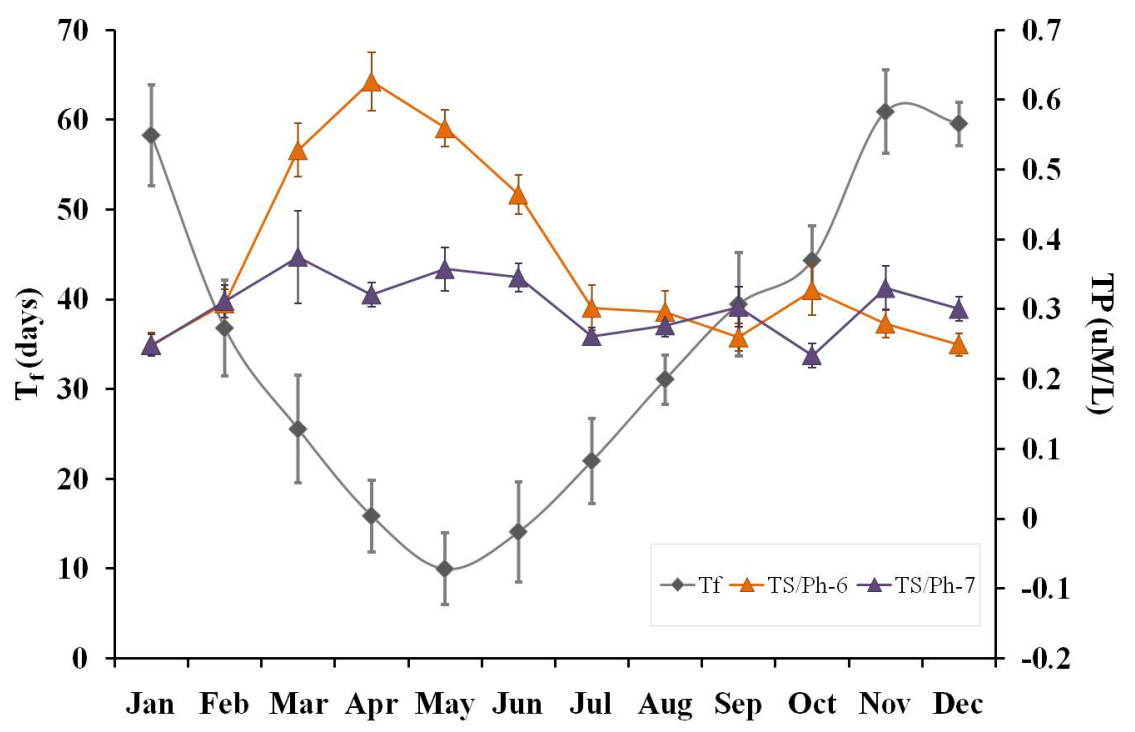

Figure 3.49. Monthly average Total Phosphorus of the coastal sites (TS/Ph-6 and TS/Ph7) of southern Taylor Slough from 2001 - 2011 with standard error bars. Water flushing times (blue diamond) are also graphed with standard error bars.

\section{FLUX OF IONS}

Ion flux concentrations for both calcium and chloride were highest from TS/Ph-3 groundwater followed by TSB groundwater and lowest from precipitation (Figure 3.50). Concentration values of chloride for TS/Ph-3 groundwater were much higher than concentration values from precipitation, surface water inflow, and TSB groundwater (Fig. 3.50A). Chloride flux concentrations for TS/Ph-3 groundwater were higher in 2011 with a value of $7.78 \times 10^{9}\left(\mathrm{~m}^{3} /\right.$ year $)(\mathrm{meq} / \mathrm{L})$. The highest calcium ion flux groundwater value from TS/Ph-3 was for 2011 with a value of $1.05 \times 10^{9}\left(\mathrm{~m}^{3} /\right.$ year $)(\mathrm{meq} / \mathrm{L})($ Fig. 3.50B). Calcium flux concentration values for TSB groundwater for 2011 were $1.67 \times 10^{8}$ $\left(\mathrm{m}^{3} /\right.$ year $)(\mathrm{meq} / \mathrm{L})$ while the chloride flux concentration values were $2.63 \times 10^{7}$ $\left(\mathrm{m}^{3} /\right.$ year)(meq/L). Ion flux concentration values of calcium and chloride for $Q_{\text {in }}$ were 
higher in 2009 with values of $2.26 \times 10^{8}\left(\mathrm{~m}^{3} /\right.$ year $)(\mathrm{meq} / \mathrm{L})$ and $9.94 \times 10^{7}$ $\left(\mathrm{m}^{3} /\right.$ year $)(\mathrm{meq} / \mathrm{L})$ respectively. Precipitation ion flux concentrations of chloride and calcium were higher in 2009 with values of $1.14 \times 10^{7}\left(\mathrm{~m}^{3} /\right.$ year $)(\mathrm{meq} / \mathrm{L})$ and $2.19 \times 10^{7}$ $\left(\mathrm{m}^{3} /\right.$ year $)(\mathrm{meq} / \mathrm{L})$ respectively.

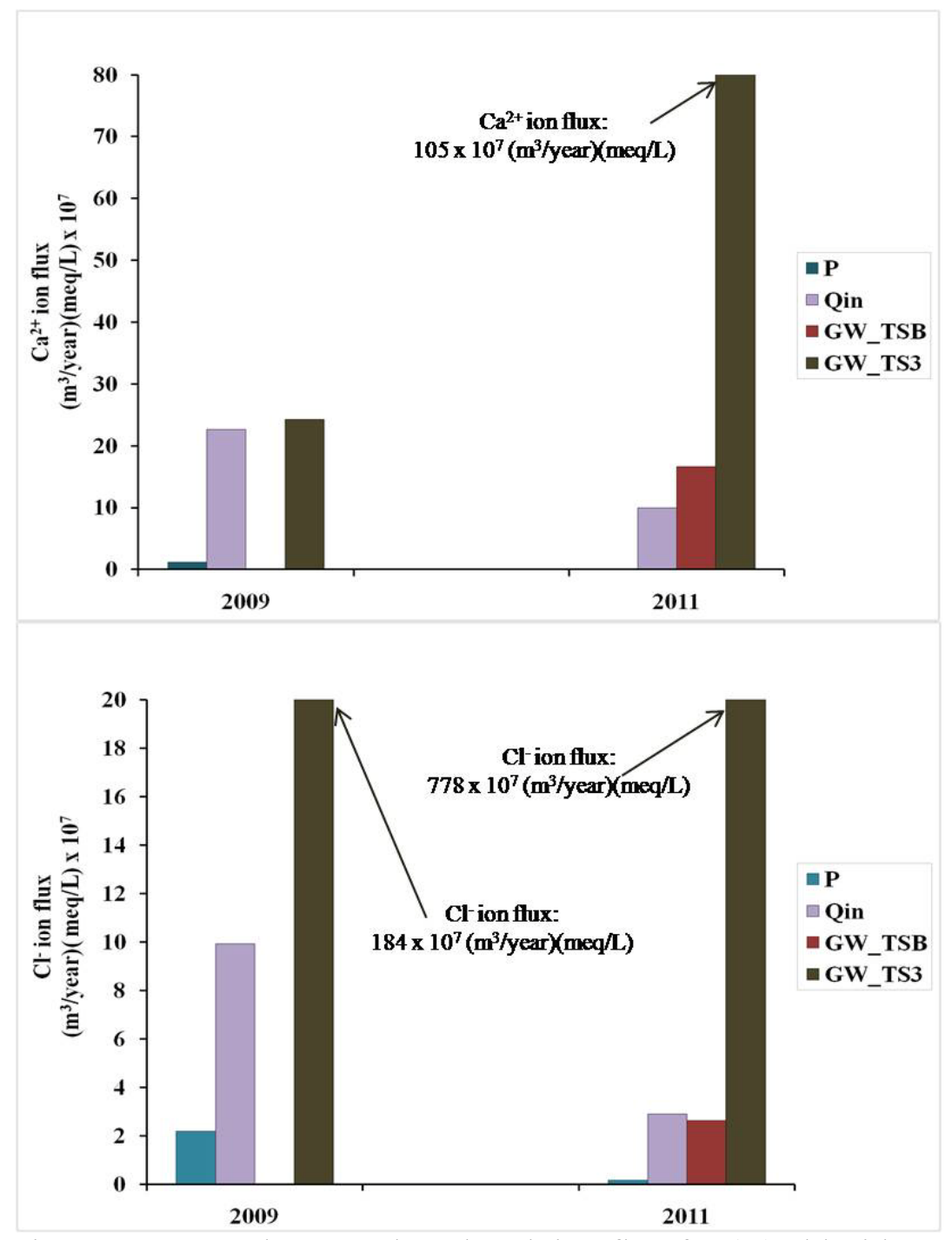

Figure 3.50. Southern Taylor Slough ion flux for (A) chloride and (B) calcium multiplied by precipitation (P), surface water inflow (Qin), Groundwater (GW) at TSB and TS3.

There was an increase in average chloride ion concentrations with increasing average values of stable isotopes of $\delta^{18} \mathrm{O}$ (Fig. 3.51) in the freshwater portion of southern 
Taylor Slough, a trend that was not observed with average calcium ion concentrations (Fig. 3.52). Groundwater at TS/Ph-3 in the 2008/2009 and 2011/2012 samplings had average chloride ion concentration values of $215.74 \mathrm{meq} / \mathrm{L}$ and $173.70 \mathrm{meq} / \mathrm{L}$ respectively. Average chloride concentrations at TS/Ph-1, TS/Ph-2, TSB (groundwater and surface water), TS/Ph-3, and TS3 surface waters ranged from $0.36 \mathrm{meq} / \mathrm{L}$ to 3.95 meq/L from samples ranging between 1998-1999 and 2008 - 2012. Average calcium concentrations for the freshwater portion of southern Taylor Slough ranged between 2.21 $\mathrm{meq} / \mathrm{L}$ to $28.42 \mathrm{meq} / \mathrm{L}$ for surface water and groundwater (Figure 3.53). The higher average calcium values of $28.32 \mathrm{meq} / \mathrm{L}$ and $24.34 \mathrm{meq} / \mathrm{L}$ were from TS3 groundwater from 2008/2009 and 2011/2012 samplings respectively. The groundwater at TSB and the surface water at TS/Ph-1, TS/Ph-2, TSB, TS/Ph-3, and TS3 had average calcium concentrations from $2.21 \mathrm{meq} / \mathrm{L}$ to $8.29 \mathrm{meq} / \mathrm{L}$.

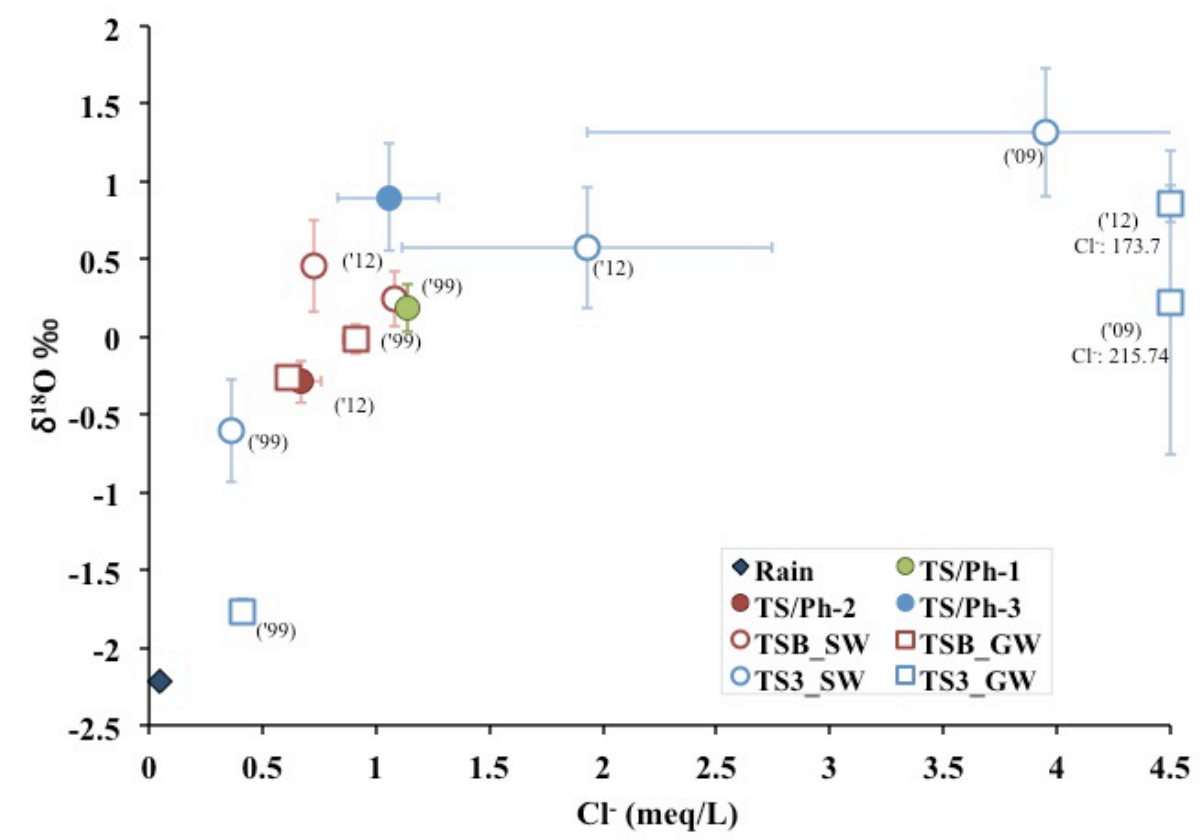

Figure 3.51. Chloride (meq/L) and stable isotopes of oxygen (\%o) for the freshwater sites of southern Taylor Slough. Chloride values for TS/Ph-3 groundwater (TS3_GW) for 2009 and 2012 were higher than the other samples and are labeled. 


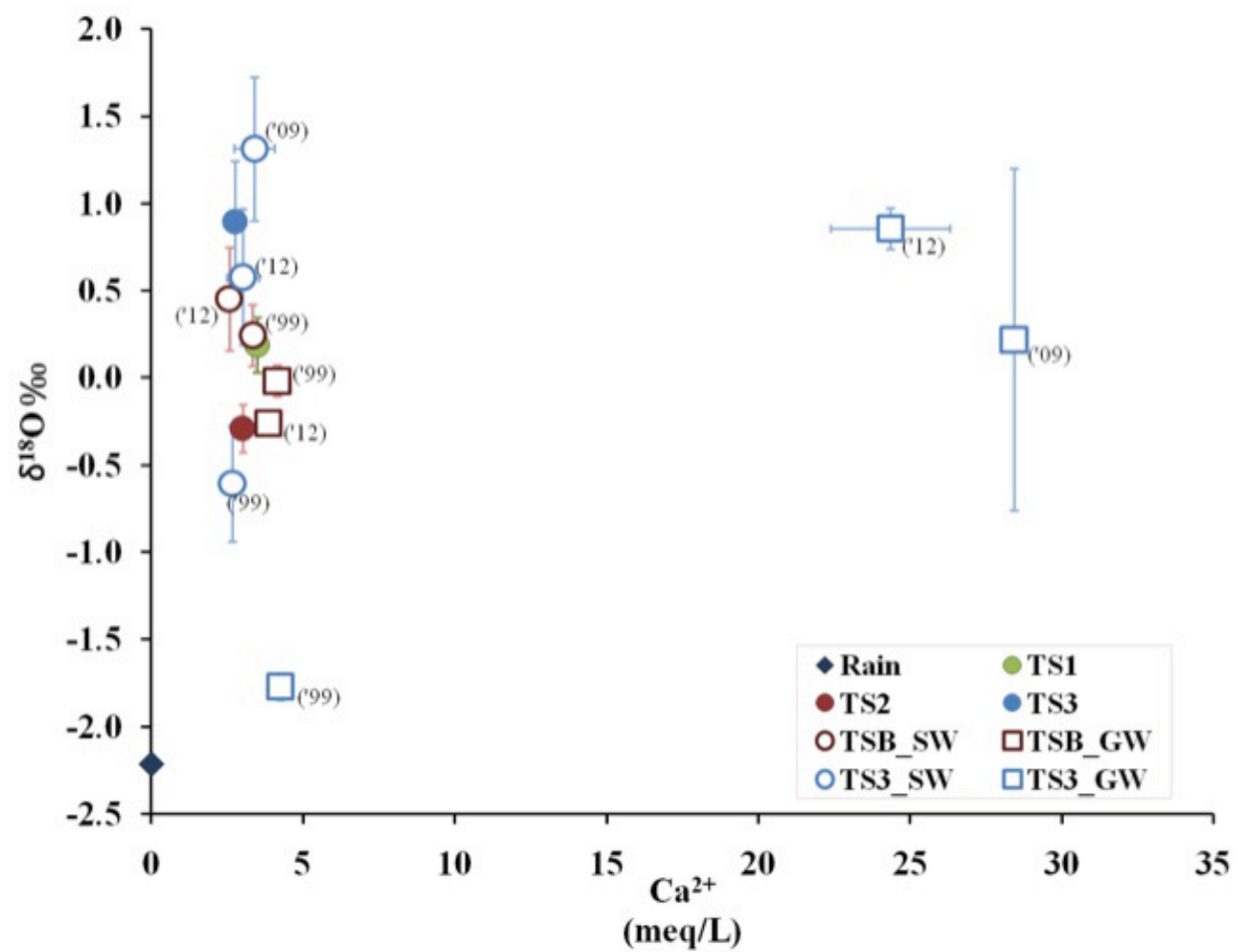

Figure 3.52. Calcium (meq/L) and stable isotopes of oxygen (\%o) for the freshwater sites of southern Taylor Slough.

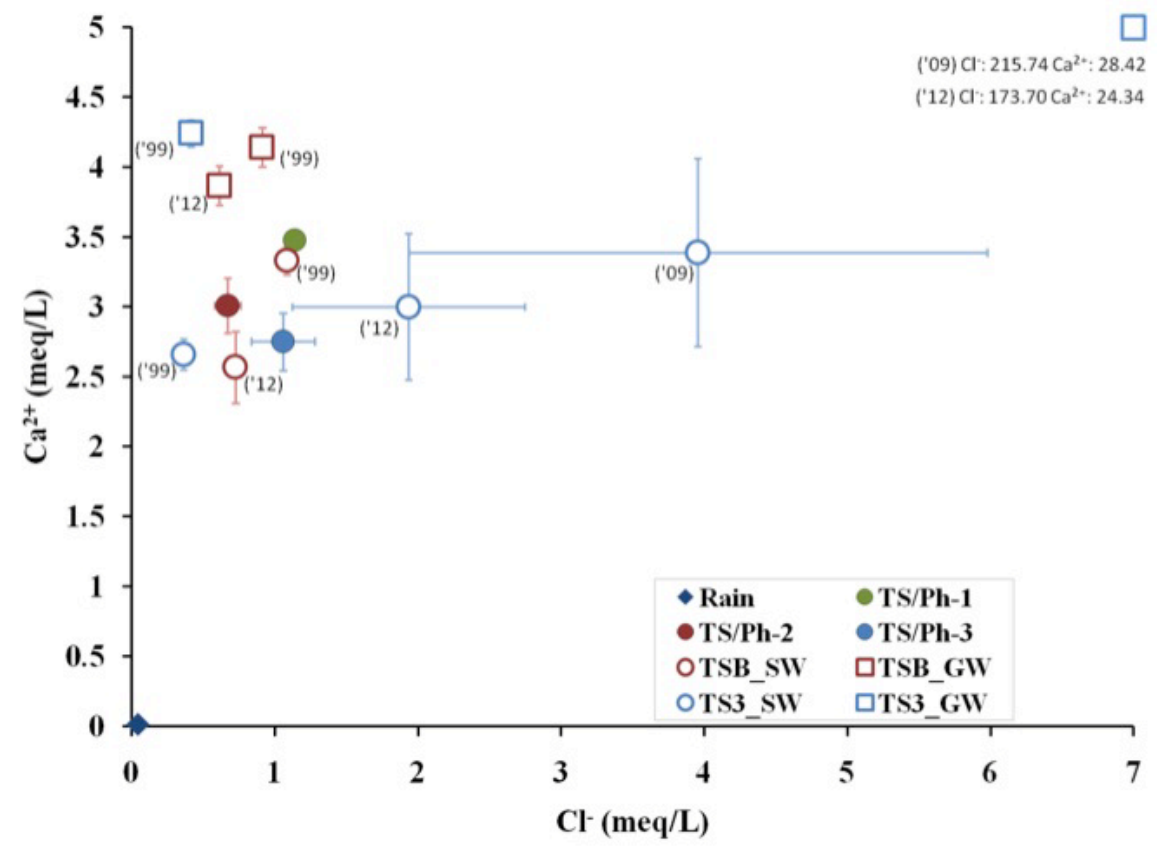

Figure 3.53. Chloride and calcium ion concentration averages for the freshwater sites of southern Taylor Slough. Groundwater at TS3 for 2009 and 2012 had ion values higher than the other samples and are labeled. 


\section{CHAPTER 4}

\section{DISCUSSION}

\section{WATER FLUSHING TIMES}

Water flushing times is a system-wide measurement (Monsen et al. 2002) of the amount of time water spends in a system (Alber and Sheldon 1999). The term 'water flushing time' was used in this study, with values obtained using Eq.1 representing the defined area of southern Taylor Slough (Fig. 1.3). Water flushing time's system-wide approach can lead to loss of observing smaller scale changes within the system, which can be substantial in a non-heterogeneous area. Flushing times between January 2001 and December 2011 varied between 3 days (May 2009) and 78 days (November 2008) with values of 35 days and longer composing approximately $58 \%$ of the values. Previous work in the coastal area of Taylor Slough consistently estimated flushing times (named residence time) in estuarine Taylor River ponds between 1 to 5 days with values reaching up to approximately 80 days (Koch et al. 2012). Koch et al. (2012) also observed longer flushing times in the dry season and in the larger ponds included in the study. The difference in flushing time trends are a possible result of the spatial difference used to estimate the term, as basins with larger volumes tend to give longer flushing time estimates than those with smaller volumes (Alber and Sheldon 1999, Cifuentes et al. 1990).

Previous flushing time studies in estuarine environments have found flushing time to be affected more by river discharge than by volume, observing increased flushing times with decreasing discharge and vice versa (Alber and Sheldon 1999). Alber and 
Sheldon (using surface water inputs, $Q_{\text {in }}$, as opposed to surface water output, $Q_{\text {out }}$ ) assumed freshwater inputs into the estuary were primarily from river discharge, considering precipitation, evapotranspiration, and groundwater variables negligible. For the water flushing time estimations of this work, total output $\left(\mathrm{Q}_{\text {TOut }}\right)$ included evapotranspiration (ET) and groundwater recharge (negative GW) in addition to Qout. Water flushing times for the whole southern Taylor Slough depicted a similar relationship as Alber and Sheldon using $\mathrm{Q}_{\text {TOut }}$ and not just $\mathrm{Q}_{\text {out. }}$ Increased $\mathrm{Q}_{\text {TOut }}$ resulted in shorter flushing times and longer flushing times with decreased $\mathrm{Q}_{\text {TOut. }}$ Evapotranspiration was the major contributor to $\mathrm{Q}_{\text {TOut }}$, averaging $76 \%$ of the $\mathrm{Q}_{\text {TOut }}$ during the ten-year study. On a monthly time-scale for the ten-year study period, the average $T_{f}$ were shortest in the month of May, coinciding when ET was highest (Figure 3.20). The longest monthly average flushing time (December) also coincided with the lowest ET monthly average for the ten-year study period. The findings support previous work that found ET as the primary variable by which water exits Taylor Slough (Zapata-Rios and Price 2012). Zapata-Rios and Price (2012) found a similar ET trend, with higher ET values at the end of the dry season (May) and lower values at the beginning of the dry season (November), albeit our lower values were found to be in December with November only slightly lower. Although ET played the largest influence in the flushing time calculation for $\mathrm{Q}_{\text {Tout }}$, volume $(\mathrm{V})$, the numerator of the flushing time calculation also played a significant role. The $\mathrm{R}^{2}$ value of 0.362 for the relationship between $\mathrm{V}$ and $\mathrm{T}_{\mathrm{f}}$ (Figure 3.9) was lower than the $\mathrm{R}^{2}$ value of 0.585 for the relationship between ET and $\mathrm{T}_{\mathrm{f}}$ (Figure 3.23) signaling to the slightly higher influence of $\mathrm{ET}$ than $\mathrm{V}$ in the $\mathrm{T}_{\mathrm{f}}$ calculation. When monthly $\mathrm{V}$ values surpassed monthly ET values, flushing times were longer with values typically between 
30 - 60 days (Figure 4.1). When ET values surpassed V values, flushing times were usually less than 30 days. With surface water volume having an influence on flushing times, increasing and/or decreasing volume of surface water in southern Taylor Slough would result in an increase/decrease in flushing times as well.

Daily flushing time estimations using data from Zapata-Rios and Price (2012) from January 1, 2008 to July 31, 2009 showed high variability from day to day (Figure 3.2), particularly between the months of August 2008 - December 2008 when volume values were higher. With longer time-scales, the water flushing time variability decreased (Figure 3.3). Values of estimated water flushing times by month using Zapata-Rios and Price (2012) data as compared to values estimated using data obtained for the study had a correlation value of $84.8 \%$. The largest difference occurred in ET estimates, with the study's data having higher ET estimates than Zapata-Rios and Price (2012). The study's ET data, obtained via EDEN, uses potential evapotranspiration (PET) estimates, which is the maximum amount of evapotranspiration that can occur with a readily available water source. Zapata-Rios and Price (2012) estimated ET using the Penman-Monteith equation using data from the weather tower located at $\mathrm{TS} / \mathrm{Ph}-7$ to represent the whole study area. 


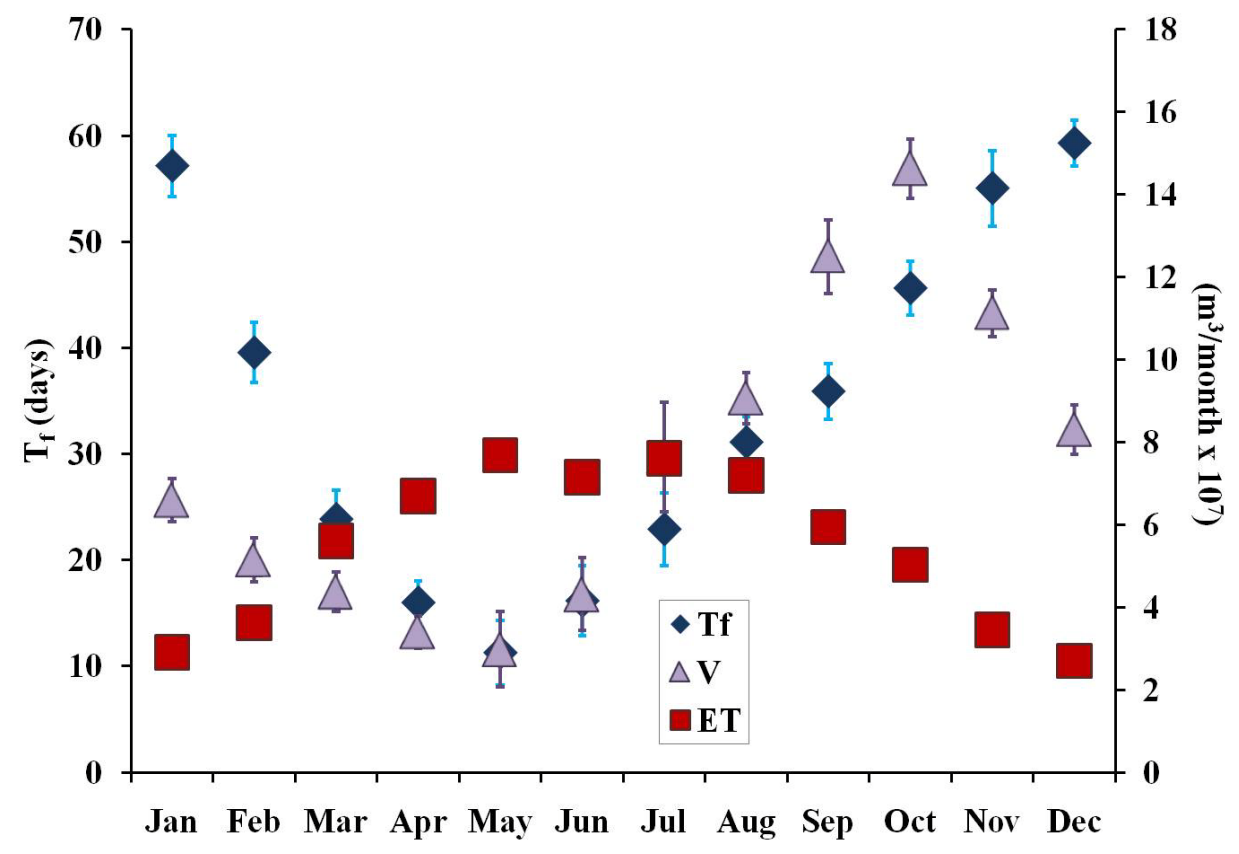

Figure 4.1. Monthly averages of ET (square), Volume (triangle), and Flushing Times (diamond) for southern Taylor Slough for January 2001 - December 2011 with standard error bars.

From the precipitation relationships, the ratio of $\mathrm{Q}_{\text {in }}$ and rainfall at Taylor Slough Bridge (TSB) (Figure 3.30) was the relationship with the highest insight to water management effects. The relationship between cumulative $Q_{\text {in }}$ and cumulative rainfall at TSB (Figure 3.31) had a relatively constant slope albeit showing a seasonal signal with slightly decreased slopes in the dry season (decreased flow per unit rainfall) and increased slopes in the wet season (increased flow per unit rainfall). A noticeable change in slope occurred between October 2005 and September 2008, where the slope decreased to 2.09 (decreased flow per unit rainfall). The period of decreased slope coincided with the years 2006 and 2008 when there was lower than average total precipitation (Figure 3.12). Comparing $Q_{\text {in }}$ at TSB with surface water discharge from S332 (Figure 3.32) and rainfall (Figure 3.33), $Q_{\text {in }}$ at TSB demonstrated a higher correlation with S332 discharge 
$\left(\mathrm{R}^{2}=.6024 ; \mathrm{p}<0.05\right)$ as compared to rainfall $\left(\mathrm{R}^{2}=0.1919 ; \mathrm{p}<0.05\right)$. The higher relationship of $\mathrm{Q}_{\text {in }}$ at TSB with S332 demonstrates the high influence of S332 discharge to inflow into southern Taylor Slough. Renshaw and Kotun (2012) observed an improvement of $\mathrm{Q}_{\text {in }}$ due to water management effects and the restoration projects from 1960 to 2010 with a noticeable increase in the slope between $Q_{\text {in }}$ and rainfall at TSB from 1995 to 2010, improving the linear flow - rainfall relationship of Taylor Slough.

Although water management effects and restoration efforts have had a positive effect on $\mathrm{Q}_{\text {in }}$ to southern Taylor Slough, the continued success of such work is still driven by precipitation. If there is no precipitation, there is no surface water to be discharged from S332 to TSB and into southern Taylor Slough.

\section{WATER CHEMISTRY AND FLUSHING TIMES}

The freshwater site with the highest correlation of ion concentration with water flushing times was TS/Ph-3 with sodium having the highest correlation with an $\mathrm{R}^{2}$ of $0.33(\mathrm{p}<0.05)$. There was no significant correlation between ion chemistry and water flushing times at the northern freshwater sites of TS/Ph-1 and TS/Ph-2 due to the location of the two northernmost sites being outside of the southern Taylor Slough area where $T_{f}$ was calculated. Ion concentrations of sodium $\left(\mathrm{Na}^{+}\right)$, magnesium $\left(\mathrm{Mg}^{2+}\right)$, potassium $\left(\mathrm{K}^{+}\right)$, and chloride $\left(\mathrm{Cl}^{-}\right)$at $\mathrm{TS} / \mathrm{Ph}-3$ increased during the dry season when shorter flushing times were observed. Local rainfall has low but detectable concentrations of $\mathrm{Na}^{+}$and $\mathrm{Cl}^{-}$due to sea spray (Price and Swart, 2006), with evaporative concentration of the ions during the dry season a possible cause as to the flushing time relationship with the ions at $\mathrm{TS} / \mathrm{Ph}-3$. Overall, average ion concentrations at $\mathrm{TS} / \mathrm{Ph}-1$ were higher than at $\mathrm{TS} / \mathrm{Ph}-2$ and $\mathrm{TS} / \mathrm{Ph}-3$. 
The observed gradient of decreasing ion concentrations from $\mathrm{TS} / \mathrm{Ph}-1$ southwards to TS/Ph-3 (Figures 3.41, 3.42) signals to a decreased influence of surface water input from the S332 pump stations at the northernmost site and to an increased influence of precipitation at $\mathrm{TS} / \mathrm{Ph}-3$. Nutrient data for $\mathrm{TN}$ at $\mathrm{TS} / \mathrm{Ph}-3$ showed a very similar trend to $\mathrm{Na}^{+}, \mathrm{Mg}^{2+}, \mathrm{K}^{+}$, and $\mathrm{Cl}^{-}$ion concentrations for the site, increasing with shorter flushing times and decreasing with longer flushing times. The observed trend at $\mathrm{TS} / \mathrm{Ph}-3$ is a probable effect of increased evaporation of surface water with a concentration of the ions and TN in the remaining water. Observed spikes of TP during the dry season for the freshwater sites could also be caused by evaporation of the remaining standing water and biotic/abiotic processes that typically occur during marsh dry downs (Childers et al. 2006). Phosphorus being the limiting macronutrient in the Everglades, TP quickly decreases within one month following the spikes most likely due to biological uptake.

Groundwater ion concentrations at TSB were similar to the surface water at TSB, TS/Ph-1, and TS/Ph-2. From 1999 to 2011, groundwater at TS/Ph-3 changed from fresh (Price 2001) to brackish, a signal of seawater intrusion now prevalent at the site. Groundwater ion concentrations at TS/Ph-3 were significantly higher than the surface water at TS/Ph-3 (Figure 3.53), with ion concentrations resembling the coastal sites (Zapata-Rios 2009). The difference between surface water and groundwater ion concentrations (Figure 3.53) at TS/Ph-3 signaled to a lack of surface water/groundwater interactions at the site. Groundwater stable isotope values of $\delta^{18} \mathrm{O}$ and $\delta \mathrm{D}$ have also increased from negative in 1999 to positive in 2011 (Figure 3.45) which further corroborates the observed increase in groundwater ion concentrations at $\mathrm{TS} / \mathrm{Ph}-3$ and signals to a change of source for the groundwater. Price and Swart (Price and Swart 
2006) identified the negative isotopic values of the $\mathrm{TS} / \mathrm{Ph}-3$ groundwater of 1999 as having a source from the Rocky Glades, the western boundary of Taylor Slough. The change to positive isotopic values of the $\mathrm{TS} / \mathrm{Ph}-3$ groundwater signals to seawater mixing of the groundwater, supporting the high ion concentrations. Although there was an observed correlation between the groundwater $(\mathrm{GW})$ variable of the water budget equation and ion concentrations at $\mathrm{TS} / \mathrm{Ph}-3$, the chemistry data does not indicate to groundwater/surface water interactions occurring at the site. No correlation was found between the surface water ion concentrations at TS/Ph-1 or TS/Ph-2 and the GW variable of the water budget equation. The lack of a correlation does not necessarily mean a lack of groundwater/surface water interactions, as the ion and isotope characteristics of groundwater and surface water at the northern end of southern Taylor Slough are similar. Studies in the northern portion of Taylor Slough have also found increasing groundwatersurface water interactions with the inclusion of the retention basins and detention areas by the headwaters of Taylor Slough (Sullivan et al. 2013).

In southern Taylor Slough, the water chemistry of the coastal sites (Figures 3.46, 3.47) differed considerably with the freshwater sites (Fig. 3.41, 3.42). Ion concentrations at the coastal sites were inversely related to flushing times, decreasing with longer flushing times and increasing with shorter flushing times. Increased ion concentrations coincided with the dry season, when ET values were high and precipitation was low. High ET values and low precipitation can lead to increased ion concentrations, but groundwater discharge could be another cause. The relationship between ion concentrations, flushing times, and groundwater values indicate to groundwater discharge in the coastal sites, a pattern also observed in previous works (Zapata-Rios and Price 
2012, Michot et al. 2011). The relationship between increasing/decreasing water flushing times and decreasing/increasing ion concentrations at the coastal sites coincides with periods of groundwater recharge/discharge. Shorter flushing times and increasing ion concentrations usually coincided with a positive groundwater $(+\mathrm{GW})$ in the water budget calculations, indicating groundwater discharge while longer flushing times and decreasing ion concentrations coincided with groundwater recharge. With longer flushing times, ion concentrations and at the coastal sites generally decrease.

\section{FLUX OF IONS}

Precipitation has been shown to be the main contributor of freshwater inputs into the study site (Childers et al. 2006, Nuttle et al. 2000, Zapata-Rios 2009), while the main contributor of ions is thought to be a groundwater source (Price et al. 2006). Located at the northern end of the Everglades Mangrove Ecotone Region (EMER), the brackish groundwater at $\mathrm{TS} / \mathrm{Ph}-3$ has the potential to be a dominant source of ions for the freshwater site with the groundwater flux of ions at the site being approximately an order of magnitudes or more higher than groundwater flux of ions at TSB, precipitation, and surface water inflow (Figure 3.50). Currently, the isotopic and ionic data at $\mathrm{TS} / \mathrm{Ph}-3$ show no evidence of groundwater flux occurring at TS/Ph-3. When looking at the stable isotopes of oxygen with the ion concentrations of chloride (Figure 3.53), a trend of increasing $\delta^{18} \mathrm{O}$ with increasing chloride ions is observed until a threshold at a value of approximately 1.5 per mil is reached. The observed trend is a typical $\delta^{18} \mathrm{O}$ evaporation line in the freshwater sites. The observed evaporation line is a probable effect of 
precipitation being the main source of ions in the freshwater portion with evaporation leading to increasing values of $\delta^{18} \mathrm{O}$ and ion concentrations downstream, especially during the dry season, with the high chloride concentrations in the TS/Ph-3 groundwater clearly demonstrating sweater intrusion .

\section{CHAPTER 5}

\section{CONCLUSIONS}

Flushing times in southern Taylor Slough varied from 3 days to 78 days with values of 35 days and longer composing approximately $58 \%$ of the values for the period of January 2001 - December 2011. The variables of volume and $Q_{\text {TOut }}$ that compose the numerator and denominator of the flushing time calculation (Eq.1) both show great influence in the values obtained for southern Taylor Slough, with volume having a lower influence than ET. The variable with the highest influence in the sum of total outflow was ET, composing an average of $76 \%$ of the total output of southern Taylor Slough for the ten-year study period. Longer monthly flushing times (30 days and longer) were observed when surface water volumes exceeded ET, while shorter monthly flushing times (less than 30 days) were observed when surface water volumes were less than ET. Increasing surface water volume as a result of changing water management practices would result in longer flushing times in southern Taylor Slough. The availability of surface water inflow through TSB is influenced by both precipitation and discharge from the S332 areas, with a greater relationship observed between inflow and S332 discharge than with precipitation. Although an increase in the flow - rainfall linear relationship has been observed since restoration projects from 1995 to present, precipitation is still the driving 
factor as to the availability of discharge from S332 and into southern Taylor Slough. With increasing volume due to increased surface water flow made available by water management practices and restoration projects, flushing times are also expected to increase in southern Taylor Slough.

A negative correlation was observed between the water chemistry and flushing times at the coastal sites and TS/Ph-3, with increasing ion concentrations during shorter flushing times and decreasing ion concentrations with longer flushing times. At the northern end of the EMER, TS/Ph-3, TN also had an inverse relationship with flushing times. Longer flushing times will thus result in decreased ion concentrations in the EMER region of southern Taylor Slough. The major source of ions to the freshwater portion of Taylor Slough is precipitation with increasing value of $\delta^{18} \mathrm{O}$, ions, and TN and TP showing an evaporation effect occurring at the freshwater sites during the dry season. 


\section{REFERENCES}

Alber, M. and J. Sheldon, 1999. Use of a Date-specific Method to Examine Variability in the Flushing Times of Georgia Estuaries. Estuarine, Coastal and Shelf Science 49, p. 469-482.

Armentano, T., Sah, J., Ross, M., Jones, D., Cooley, H. and C. Smith, 2006. Rapid responses of vegetation to hydrological changes in Taylor Slough, Everglades National Park, Florida, USA. Hydrobiologia, 569, p. 293-309.

Boesch, D., Armstrong, N., D’Elia, C., Maynard, N., Pearl, H. and S. Williams, 1993. Deterioration of the Florida Bay ecosystem: An evaluation of the scientific evidence. Interagency Working Group report to National Fish and Wildlife Foundation, National Park Service, Washington, D. C. 32 p.

Bolin, B. and H. Rodhe, 1973. A note on the concepts of age distribution and transit time in natural reservoirs. Tellus, 25, p. 58-62.

Childers, D., Boyer, J., Davis, S., Madden, C., Rudnich, D. and F. Sklar, 2006. Relating precipitation and water management to nutrient concentrations in the oligotrophic" upside-down" estuaries of the Florida Everglades. Limnology and Oceanography, 51, p. 602-616.

Cifuentes, L., Schemel, L. and J. Sharp, 1990. Qualitative and numerical analyses of the effects of river inflow variations on mixing diagrams in estuaries. Estuarine, Coastal and Shelf Science, 30, p. 411-427.

Cole, J., Caraco, N, and G. Likens, 1990. Short-range atmospheric transport: A significant source of phosphorus to an oligotrophic lake. Limnology and Oceanography, 35 , p. $1230-1237$

Conrads, P. and E. Roehl, 2006. Estimating water depths using artificial neural networks. Hydroinformatics, 3, p. 1643-1650.

Gaiser, E., Price, R., Scinto, L. and J. Trexler, 2010. CA H5297-02-0106, Phosphorus retention and sub-surface movement through the S-332 detention basins on the eastern boundary of Everglades National Park \& CA H5000-06-5040, TA J5297-08-0001, Modeling of Phosphorus Retention and Sub-Surface Movement through the S-332 Detention Basins on the Eastern Boundary of Everglades National Park (Phase-II). Comprehensive Final Report to Everglades National Park, FL 370 p.

Harvey, J. and P. McCormick, 2009. Groundwater's significance to changing hydrology, water chemistry, and biological communities of a floodplain ecosystem, Everglades, South Florida, USA. Hydrogeology Journal, 17, p. 185-201. 
Hollander, G., 2008. Raising cane in the 'glades: the global sugar trade and the transformation of Florida. University of Chicago Press, Chicago, IL, p. 336.

Holling, C., Gunderson, L. and C. Walters, 1994. The structure and dynamics of the Everglades system: guidelines for ecosystem restoration. In Everglades The Ecosystem and Its Restoration, Davis, S.M. and Ogden, J.C. eds. St, Lucie Press, Boca Raton, FL (USA), p. 741-756.

Huang, W., 2007. Hydrodynamic modeling of flushing time in a small estuary of North Bay, Florida, USA. Estuarine, Coastal and Shelf Science, 74, p. 722 - 731.

Jassby, A., Goldman, C. and J. Reuter, 1995. Long-term change in Lake Tahoe (California-Nevada, USA) and its relation to atmospheric deposition of algal nutrients. Archiv für Hydrobiologie, 135, p. 1-21.

Kirsch, M., 2004. The Politics of Place: Legislation, Civil Society, and the 'Restoration' of the Florida Everglades. Social Movements: A Reader, p. 203-215.

Koch, G., Childers, D., Staehr, P., Price, R., Davis, S. and E. Gaiser, 2012 Hydrological Conditions Control P Loading and Aquatic Metabolism in an Oligotrophic, Subtropical Estuary. Estuaries and Coasts, 35, p. 292-307.

Langevin, C., Swain, E., and M. Wolfert. 2005. Simulation of Integrated Surfacewater/ground-Water Flow and Salinity for a Coastal Wetland and Adjacent Estuary. Journal of Hydrology. 314.1, 212-34.

Mecikalski, J., Sumner, D., Jacobs, J., Pathak, C., Paech, S., and E. Douglas, 2011. Use of Visible Geostationary Operational Meteorological Satellite Imagery in Mapping Reference and Potential Evapotranspiration Over Florida. In Evapotranspiration, Leszek Labedzki editor. InTech Open (USA). Chapter 10.

Michot, B., Meselhe, E., Rivera-Monroy, V., Coronado-Molina, C. and R. Twilley, 2011. A tidal creek water budget: Estimation of groundwater discharge and overland flow using hydrologic modeling in the Southern Everglades. Estuarine, Coastal and Shelf Science, 93, p. 438-448.

Monsen, N., Cloern, J., Lucas, L. and S. Monismith, 2002. A comment on the use of flushing time, residence time, and age as transport time scales. Limnology and Oceanography, 47, p. 1545-1553.

Noe, G., Childers, D. and R. Jones, 2001. Phosphorus biogeochemistry and the impact of phosphorus enrichment: Why is the Everglades so unique?. Ecosystems, 4, p. 603-624. 
Nuttle, W., Fourqurean, J.,, Cosby, B., Zieman, J. and M. Robblee, 2000. Influence of net freshwater supply on salinity in Florida Bay. Water Resources Research, 36, p. 18051822.

Ogden, L., 2008. The Everglades ecosystem and the politics of nature. American Anthropologist, 110, p. 21-32.

Price, R., Savabi, M., Jolicoeur, J. and R. Srikumar, 2010. Adsorption and desorption of phosphate on limestone in experiments simulating seawater intrusion. Applied Geochemistry, 25, p. 1085-1091.

Price, R., Nuttle, W., Cosby, B., and P. Swart, 2007. Variation and Uncertainty in Evaporation from a Subtropical Estuary: Florida Bay. Estuaries and Coasts, 30, p. 497 506.

Price, R. and P. Swart, 2006. Geochemical indicators of groundwater recharge in the surficial aquifer system: Everglades National Park, Florida, USA. Geological Society of America Special Paper, 404, p. $251-266$.

Price, R., Swart, P. and J. Fourqurean, 2006. Coastal groundwater discharge-an additional source of phosphorus for the oligotrophic wetlands of the Everglades. Hydrobiologia, 569, p. 23-36.

Price, R., 2001. Geochemical determinations of groundwater flow in Everglades National Park, Ph.D. dissertation, University of Miami, Coral Gables, FL, 307 p.

Prospero, J., Barrett, K., Church, T., Dentener, F., Duce, R., Galloway, J., Levy, H., Moody, J. and P. Quinn, 1996. Atmospheric deposition of nutrients to the North Atlantic Basin. Biogeochemistry, 35, p. 27-73.

Renshaw, A. and K. Kotun, 2012. Taylor Slough Hydrology The Effects of Water Management 1960 - 2010. Technical report to South Florida Natural Resources Center, National Park Service, Homestead, FL, 57 p.

Rivera-Monroy, V., Twilley, R. and S. Davis, 2011. The Role of the Everglades Mangrove Ecotone Region (EMER) in Regulating Nutrient Cycling and Wetland Productivity in South Florida. Critical Reviews in Environmental Science and Technology, 41, p. 633-669.

Sklar, F., Chimney, M., Newman, S., McCormick, P., Galwik, D., Miao, S., McVoy, C., Said, W., Newman, J. and C. Coronado, 2005. The ecological-societal underpinnings of Everglades restoration. Frontiers in Ecology and the Environment, 3, p. 161-169. 
Sullivan, P., Price, R., Schedlbauer, J., Saha, A. and E. Gaiser, 2013. The influence of hydrologic restoration on groundwater - surface water interactions in a karst wetland, Everglades, Florida, USA. Wetlands, in review. Journal ad in review.

Sutula, M., Day, J., Cable, J. and D. Rudnick, 2001. Hydrological and nutrient budgets of freshwater and estuarine wetlands of Taylor Slough in Southern Everglades, Florida (USA). Biogeochemistry, 56, p. 287-310.

Tillis, G., 2001. Measuring Taylor Slough boundary and internal flows, Everglades National Park, Florida. US Dept. of the Interior, US Geological Survey Open-File Report 01-255, $16 \mathrm{p}$.

Zapata-Rios, X. and R. Price, 2012. Estimates of groundwater discharge to a coastal wetland using multiple techniques: Taylor Slough, Everglades National Park, USA. Hydrogeology Journal, 20, p. 1651 - 1668.

Zapata-Rios X., 2009. Groundwater/surface water interactions in Taylor SloughEverglades National Park. M.S. Thesis, Florida International University, Miami, FL, 183 p. 


\section{APPENDICES}

APPENDIX A. Annual sum of water budget and flushing time variables in $\mathrm{m}^{3} /$ year $\mathrm{x} 10^{5}$ for Taylor Slough, Everglades National Park, including average and standard error (SE) for 2001-2011 (11 years).

\begin{tabular}{|c|c|c|c|c|c|c|c|c|c|c|c|c|c|}
\hline $\begin{array}{c}\text { Variable } \\
\left(\mathrm{m}^{3} / \mathrm{yr} \times 10^{5}\right)\end{array}$ & 2001 & 2002 & 2003 & 2004 & 2005 & 2006 & 2007 & 2008 & 2009 & 2010 & 2011 & Average & SE \\
\hline Rain & 6425 & 4888 & 5364 & 3679 & 5917 & 4960 & 5782 & 4208 & 5632 & 5685 & 5239 & 5253 & 238 \\
\hline Inflow & 937 & 717 & 1097 & 427 & 1137 & 298 & 179 & 782 & 890 & 619 & 351 & 676 & 99 \\
\hline ET & -6358 & -6507 & -6360 & -6604 & -6578 & -6622 & -6564 & -6675 & -6707 & -6362 & -6819 & -6560 & 46 \\
\hline Outflow & -953 & -1072 & -1098 & -568 & -1739 & -908 & -905 & -753 & -1141 & -1232 & -737 & -1010 & 94 \\
\hline Change in Storage & 339 & -133 & 14 & -292 & 213 & -188 & 31 & 159 & 339 & -427 & -3 & 5 & 75 \\
\hline Groundwater & 288 & 1840 & 1011 & 2774 & 1476 & 2083 & 1539 & 2597 & 1665 & 863 & 1963 & 1645 & 222 \\
\hline Total Error & 1594 & 1464 & 1526 & 1347 & 1617 & 1491 & 1596 & 1415 & 1580 & 1549 & 1532 & 1519 & 25 \\
\hline Total Outflow & 10101 & 8499 & 9010 & 7791 & 9866 & 8460 & 8524 & 8002 & 8925 & 8983 & 8495 & 8787 & 212 \\
\hline Volume & 7449 & 9400 & 10851 & 7492 & 9669 & 8252 & 9055 & 8170 & 9823 & 10732 & 8221 & 9010 & 360 \\
\hline Flushing Time* & $\begin{array}{c}22 \\
(4.63) \\
\end{array}$ & $\begin{array}{c}33 \\
(4.55) \\
\end{array}$ & $\begin{array}{c}35 \\
(2.82) \\
\end{array}$ & $\begin{array}{c}28 \\
(5.97) \\
\end{array}$ & $\begin{array}{c}29 \\
(4.41) \\
\end{array}$ & $\begin{array}{c}29 \\
(4.55) \\
\end{array}$ & $\begin{array}{c}31 \\
(3.23) \\
\end{array}$ & $\begin{array}{c}30 \\
(5.90) \\
\end{array}$ & $\begin{array}{c}32 \\
(5.21) \\
\end{array}$ & $\begin{array}{c}36 \\
(4.01) \\
\end{array}$ & $\begin{array}{c}28 \\
(4.90) \\
\end{array}$ & 30 & 1 \\
\hline
\end{tabular}

*Flushing time values shown are yearly averages (standard error in parenthesis) in days. 
APPENDIX B. Water chemistry for field samples collected from 1997-1999 (Price), 2008-2009 (Zapata-Rios), and $2011-2012$ (Sandoval) for TSB and TS/Ph-3. -Tables-

$\mathrm{T}=$ Temperature $\quad$ Cond $=$ Conductivity $\quad$ Sal $=$ Salinity $\quad$ Alk $=$ Alkalinity $(\mathrm{meq} / \mathrm{L})$

B.1. TSB Surface Water (TSB_SW)

\begin{tabular}{|c|c|c|c|c|c|c|c|c|c|c|c|c|c|c|}
\hline $\begin{array}{c}\text { Site } \\
\text { Name }\end{array}$ & $\begin{array}{c}\text { Sample } \\
\text { Date }\end{array}$ & $\begin{array}{c}\mathrm{T} \\
\left({ }^{\circ} \mathrm{C}\right)\end{array}$ & $\begin{array}{l}\text { Cond } \\
(\mu S)\end{array}$ & $\begin{array}{c}\mathrm{Sal} \\
(\mathrm{ppt})\end{array}$ & $\mathrm{pH}$ & $\mathrm{Na}^{+}$ & $\mathrm{K}^{+}$ & $\mathrm{Mg}^{2+}$ & $\mathrm{Ca}^{2+}$ & $\mathrm{Cl}^{-}$ & $\mathrm{SO}_{4}{ }^{2-}$ & Alk & $\begin{array}{c}\delta^{18} \mathrm{O} \\
\% 0\end{array}$ & $\begin{array}{l}\delta \mathrm{D} \\
\% 0\end{array}$ \\
\hline \multirow[t]{17}{*}{ TSB_SW } & $2 / 24 / 97$ & 23.6 & 480 & 0.14 & 7.80 & 1.048 & 0.024 & 0.488 & 3.942 & 1.060 & 0.000 & 4.341 & 0.15 & 3.00 \\
\hline & $3 / 27 / 97$ & 25.9 & 530 & 0.18 & & 1.099 & 0.034 & 0.506 & 3.981 & 1.049 & 0.042 & 4.338 & -0.37 & 3.00 \\
\hline & $5 / 3 / 97$ & 32.3 & 540 & 0.19 & 7.83 & 1.567 & 0.051 & 0.629 & 4.028 & 1.597 & 0.131 & 4.541 & 0.05 & 9.80 \\
\hline & $5 / 28 / 97$ & 31.1 & 330 & 0.05 & 7.82 & 1.111 & 0.039 & 0.436 & 2.831 & 0.943 & 0.036 & 2.219 & 0.40 & 2.29 \\
\hline & $6 / 30 / 97$ & 33.3 & 340 & 0.05 & 7.89 & 0.840 & 0.046 & 0.421 & 2.953 & 0.972 & 0.057 & 3.202 & -0.10 & -3.38 \\
\hline & $7 / 24 / 97$ & 35 & 390 & 0.09 & 8.04 & 0.839 & 0.045 & 0.414 & 2.429 & 0.446 & 0.023 & 2.658 & -0.12 & -3.20 \\
\hline & $8 / 21 / 97$ & 34.3 & 400 & 0.09 & 8.01 & 0.935 & 0.055 & 0.472 & 2.985 & 0.986 & 0.084 & 3.606 & -0.06 & 2.08 \\
\hline & $10 / 1 / 97$ & 28.3 & 353 & 0.06 & 7.80 & 0.841 & 0.058 & 0.463 & 2.923 & 0.814 & 0.084 & 8.148 & -0.58 & -10.58 \\
\hline & $11 / 25 / 97$ & 24.2 & 410 & 0.10 & 7.50 & 0.007 & 0.054 & 0.542 & 3.268 & 1.082 & 0.020 & 3.533 & 0.73 & 2.04 \\
\hline & $12 / 11 / 97$ & 27.8 & 430 & 0.20 & 7.59 & 0.972 & 0.055 & 0.393 & 3.547 & 0.950 & 0.080 & 3.778 & -0.92 & 0.22 \\
\hline & $1 / 28 / 98$ & 21.9 & 390 & 0.10 & 8.02 & 0.762 & 0.030 & 0.392 & 3.704 & 0.670 & 0.017 & 3.744 & -1.70 & -5.06 \\
\hline & $2 / 27 / 98$ & 28 & 400 & 0.20 & 7.82 & 1.003 & 0.043 & 0.505 & 2.813 & 1.002 & 0.028 & 3.691 & -0.27 & -3.15 \\
\hline & $3 / 25 / 98$ & 25.8 & 428 & 0.20 & 7.58 & 1.097 & 0.042 & 0.553 & 3.134 & 1.061 & 0.038 & & 0.39 & 3.40 \\
\hline & $4 / 28 / 98$ & 32.2 & 437 & 0.20 & 7.72 & 1.347 & 0.044 & 0.704 & 3.277 & 1.358 & 0.071 & 3.999 & 1.45 & 11.05 \\
\hline & $6 / 3 / 98$ & 31.2 & 602 & 0.20 & 7.14 & 1.487 & 0.068 & 0.880 & 3.198 & 1.855 & 0.093 & 3.796 & 1.47 & 14.57 \\
\hline & 7/16/98 & 32.5 & 414 & 0.10 & 8.42 & 1.160 & 0.045 & 0.606 & 3.016 & 1.236 & 0.034 & 3.812 & 0.32 & 4.76 \\
\hline & $8 / 13 / 98$ & 34.1 & 430 & 0.20 & 7.94 & 1.042 & 0.038 & 0.563 & 3.060 & 1.084 & 0.026 & 3.570 & 0.62 & 5.75 \\
\hline
\end{tabular}




\begin{tabular}{|c|c|c|c|c|c|c|c|c|c|c|c|c|c|c|}
\hline $\begin{array}{c}\text { Site } \\
\text { Name }\end{array}$ & $\begin{array}{c}\text { Sample } \\
\text { Date }\end{array}$ & $\begin{array}{c}\mathrm{T} \\
\left({ }^{\circ} \mathrm{C}\right)\end{array}$ & $\begin{array}{l}\text { Cond } \\
(\mu S)\end{array}$ & $\begin{array}{l}\text { Sal } \\
(\mathrm{ppt})\end{array}$ & $\mathrm{pH}$ & $\mathrm{Na}^{+}$ & $\mathrm{K}^{+}$ & $\mathrm{Mg}^{2+}$ & $\mathrm{Ca}^{2+}$ & $\mathrm{Cl}^{-}$ & $\mathrm{SO}_{4}{ }^{2-}$ & Alk & $\begin{array}{c}\delta^{18} \mathrm{O} \\
\% 0\end{array}$ & $\begin{array}{l}\delta \mathrm{D} \\
\% 0\end{array}$ \\
\hline \multirow[t]{11}{*}{ TSB_SW } & $3 / 19 / 99$ & 19.9 & 571 & 0.20 & 7.71 & 1.120 & 0.083 & 0.584 & 4.299 & 1.215 & 0.039 & 5.160 & & \\
\hline & 4/21/99 & 25.6 & 450 & 0.20 & 8.20 & 1.298 & 0.097 & 0.565 & 2.868 & 1.365 & 0.030 & 3.261 & 2.65 & 15.60 \\
\hline & $5 / 20 / 99$ & 24.5 & 489 & 0.20 & 7.55 & 1.101 & 0.036 & 0.433 & 3.902 & 1.142 & 0.505 & 3.422 & -0.26 & 1.43 \\
\hline & $6 / 17 / 99$ & 34.5 & 447 & 0.00 & 7.85 & 1.129 & 0.046 & 0.467 & 3.052 & 1.196 & 0.027 & 3.416 & 0.62 & 7.46 \\
\hline & 7/26/99 & 28.3 & 423 & 0.10 & 7.15 & 1.080 & 0.053 & 0.484 & 3.125 & 1.115 & 0.018 & 3.337 & 0.64 & 6.09 \\
\hline & 8/18/99 & 30.1 & 452 & 0.12 & & 1.023 & 0.049 & 0.427 & 3.089 & 1.046 & 0.015 & 3.396 & 0.32 & 5.37 \\
\hline & $9 / 17 / 99$ & 31.1 & 256 & 0.00 & 7.92 & 0.936 & 0.026 & 0.403 & 4.377 & 0.933 & 0.010 & 4.406 & -0.13 & 3.01 \\
\hline & $11 / 19 / 11$ & 26.5 & 263 & 0.12 & 8.07 & 0.465 & 0.000 & 0.184 & 2.364 & 0.658 & 0.005 & & 0.60 & 2.90 \\
\hline & $2 / 24 / 12$ & 27.4 & 449 & 0.20 & 8.21 & 0.720 & 0.022 & 0.366 & 3.341 & 0.782 & 0.003 & 3.926 & 0.45 & 0.67 \\
\hline & $6 / 15 / 12$ & & 326 & 0.10 & 7.62 & 0.584 & 0.021 & 0.206 & 2.354 & 0.678 & 0.000 & 3.040 & 1.09 & -2.69 \\
\hline & $7 / 13 / 12$ & 28.7 & 326 & 0.10 & 7.52 & 0.734 & 0.023 & 0.216 & 2.229 & 0.777 & 0.000 & 2.573 & -0.33 & -3.58 \\
\hline
\end{tabular}


B.2. TSB Groundwater (TSB_GW)

\begin{tabular}{|c|c|c|c|c|c|c|c|c|c|c|c|c|c|c|}
\hline $\begin{array}{c}\text { Site } \\
\text { Name }\end{array}$ & $\begin{array}{l}\text { Sample } \\
\text { Date }\end{array}$ & $\begin{array}{c}\mathrm{T} \\
\left({ }^{\circ} \mathrm{C}\right)\end{array}$ & $\begin{array}{c}\text { Cond } \\
(\mu S)\end{array}$ & $\begin{array}{c}\text { Sal } \\
\text { (ppt) }\end{array}$ & $\mathrm{pH}$ & $\mathrm{Na}^{+}$ & $\mathrm{K}^{+}$ & $\mathrm{Mg}^{2+}$ & $\mathrm{Ca}^{2+}$ & $\mathrm{Cl}^{-}$ & $\mathrm{SO}_{4}{ }^{2-}$ & Alk & $\begin{array}{c}\delta^{18} \mathrm{O} \\
\% 0\end{array}$ & $\begin{array}{l}\delta \mathrm{D} \\
\% 0\end{array}$ \\
\hline \multirow[t]{21}{*}{ TSB_GW } & $12 / 11 / 97$ & 27 & 460 & 0.20 & 7.07 & 0.793 & 0.027 & 0.416 & 4.397 & 0.705 & 0.008 & 4.448 & -1.22 & 3.28 \\
\hline & $1 / 28 / 98$ & 24.1 & 480 & 0.20 & 7.19 & 0.869 & 0.025 & 0.430 & 4.441 & 0.748 & 0.001 & 4.489 & -0.50 & -5.06 \\
\hline & 2/27/98 & 24.3 & 480 & 0.20 & 7.09 & 0.798 & 0.021 & 0.385 & 3.576 & 0.773 & 0.000 & 4.501 & -0.25 & -2.28 \\
\hline & $3 / 25 / 98$ & 24.2 & 472 & 0.20 & 6.72 & 0.857 & 0.024 & 0.414 & 4.048 & 0.873 & 0.007 & 4.141 & -0.20 & 0.43 \\
\hline & $4 / 28 / 98$ & 24.9 & 495 & 0.20 & 6.67 & 0.903 & 0.022 & 0.408 & 4.268 & 0.926 & 0.000 & 4.627 & -0.28 & 1.05 \\
\hline & $6 / 3 / 98$ & 26.3 & 611 & 0.20 & 6.57 & 1.019 & 0.027 & 0.471 & 4.422 & 1.120 & 0.001 & 4.522 & 0.05 & 8.23 \\
\hline & $7 / 16 / 98$ & 26.8 & 525 & 0.20 & 6.65 & 1.057 & 0.032 & 0.458 & 4.377 & 1.189 & 0.001 & 3.983 & 0.40 & 3.99 \\
\hline & $8 / 13 / 98$ & 28.3 & 563 & 0.20 & 7.15 & 1.142 & 0.025 & 0.473 & 4.493 & 1.239 & 0.000 & 4.929 & 1.04 & 6.49 \\
\hline & 2/10/99 & 24.6 & 518 & 0.20 & 7.01 & 0.936 & 0.023 & 0.424 & 4.519 & 0.968 & 0.000 & 4.364 & 0.02 & 2.56 \\
\hline & 3/19/99 & 24.9 & 479 & 0.20 & 7.23 & 0.895 & 0.025 & 0.416 & 4.012 & 0.965 & 0.000 & 4.002 & -0.02 & -1.22 \\
\hline & 4/21/99 & 26.1 & 477 & 0.20 & 7.21 & 0.950 & 0.024 & 0.398 & 3.931 & 0.975 & 0.000 & 3.494 & 0.05 & 1.22 \\
\hline & $5 / 20 / 99$ & 25.3 & 480 & 0.20 & 7.29 & 0.951 & 0.021 & 0.400 & 3.958 & 0.989 & 0.014 & 4.132 & 0.02 & 1.08 \\
\hline & 6/17/99 & 24.8 & 574 & 0.00 & 7.27 & 0.993 & 0.026 & 0.423 & 4.492 & 1.059 & 0.048 & 4.328 & 0.01 & 3.76 \\
\hline & 7/26/99 & 26.5 & 553 & 0.19 & 6.92 & 0.992 & 0.028 & 0.463 & 4.413 & 1.008 & 0.100 & 3.467 & 0.12 & 3.87 \\
\hline & 8/18/99 & 27.7 & 532 & 0.18 & & 0.988 & 0.026 & 0.427 & 4.515 & 0.968 & 0.033 & 4.283 & 0.03 & 3.03 \\
\hline & 9/17/99 & 28.3 & 546 & 0.19 & 7.15 & 0.339 & 0.012 & 0.159 & 2.192 & 0.292 & 0.000 & 2.296 & -0.41 & 1.05 \\
\hline & $1 / 28 / 98$ & 24.1 & 480 & 0.20 & 7.19 & 0.870 & 0.025 & 0.433 & 4.441 & 0.752 & 0.001 & 4.509 & -0.34 & -6.21 \\
\hline & $11 / 19 / 11$ & 27.8 & 573 & 0.26 & 7.31 & 0.655 & 0.000 & 0.287 & 4.173 & 0.472 & 0.000 & & -0.30 & -0.20 \\
\hline & $2 / 24 / 12$ & 26.4 & 419 & 0.27 & 7.31 & 0.675 & 0.016 & 0.289 & 3.512 & 0.659 & 0.001 & 4.166 & -0.09 & -3.55 \\
\hline & $6 / 15 / 12$ & 24.5 & 425 & 0.20 & 7.26 & 0.578 & 0.014 & 0.275 & 3.822 & 0.675 & 0.002 & 4.283 & -0.27 & -0.77 \\
\hline & $7 / 13 / 12$ & 24.9 & 446 & 0.20 & 6.68 & 0.632 & 0.014 & 0.294 & 3.977 & 0.642 & 0.000 & 4.593 & -0.38 & 1.10 \\
\hline
\end{tabular}


B.3. TS/Ph-3 Surface Water (TS3_SW)

\begin{tabular}{|c|c|c|c|c|c|c|c|c|c|c|c|c|c|c|}
\hline $\begin{array}{c}\text { Site } \\
\text { Name }\end{array}$ & $\begin{array}{c}\text { Sample } \\
\text { Date }\end{array}$ & $\begin{array}{c}\mathrm{T} \\
\left({ }^{\circ} \mathrm{C}\right)\end{array}$ & $\begin{array}{c}\text { Cond } \\
(\mu S)\end{array}$ & $\begin{array}{c}\text { Sal } \\
(\mathrm{ppt})\end{array}$ & $\mathrm{pH}$ & $\mathrm{Na}^{+}$ & $\mathrm{K}^{+}$ & $\mathrm{Mg}^{2+}$ & $\mathrm{Ca}^{2+}$ & $\mathrm{Cl}^{-}$ & $\mathrm{SO}_{4}^{2-}$ & Alk & $\begin{array}{c}\delta^{18} \mathrm{O} \\
\% \text { o }\end{array}$ & $\begin{array}{l}\delta \mathrm{D} \\
\%\end{array}$ \\
\hline \multirow[t]{21}{*}{ TS3_SW } & $12 / 16 / 97$ & 21.1 & 320 & 0.10 & 7.83 & 0.329 & 0.067 & 0.267 & 3.590 & 0.294 & 0.000 & 3.682 & -1.65 & -6.24 \\
\hline & $2 / 4 / 98$ & 19.3 & 270 & 0.00 & & 0.295 & 0.046 & 0.236 & 2.635 & 0.275 & 0.004 & 2.720 & -1.35 & -7.44 \\
\hline & $2 / 25 / 98$ & 18.3 & 320 & 0.10 & 7.22 & 0.288 & 0.049 & 0.233 & 2.496 & 0.306 & 0.002 & 3.008 & -0.44 & 5.58 \\
\hline & $4 / 3 / 98$ & 26.8 & 310 & 0.10 & 7.95 & 0.355 & 0.046 & 0.263 & 2.887 & 0.401 & 0.018 & 3.203 & -0.30 & 6.06 \\
\hline & $6 / 4 / 98$ & 38.6 & 402 & 0.10 & 7.41 & 0.318 & 0.052 & 0.204 & 2.735 & 0.312 & 0.062 & 4.805 & -3.21 & -30.27 \\
\hline & 7/23/98 & 29.3 & 292 & 0.10 & 6.53 & 0.309 & 0.069 & 0.283 & 2.683 & 0.359 & 0.031 & 2.936 & -0.30 & 3.09 \\
\hline & $\begin{array}{c}9 / 3 / 98 \\
11 / 18 / 9\end{array}$ & 31.2 & 290 & 0.10 & 7.88 & 0.373 & 0.039 & 0.242 & 2.585 & 0.378 & 0.002 & & -0.41 & -0.53 \\
\hline & 8 & 29.7 & & 0.20 & 9.51 & 0.261 & 0.026 & 0.186 & 1.993 & 0.345 & 0.002 & 2.158 & -0.12 & 1.69 \\
\hline & 2/11/99 & 27.4 & 342 & 0.10 & 7.64 & 0.513 & 0.040 & 0.262 & 2.549 & 0.625 & 0.014 & 3.110 & 1.46 & 13.79 \\
\hline & $6 / 24 / 99$ & 34.5 & 342 & 0.00 & 7.73 & 0.469 & 0.065 & 0.200 & 2.815 & 0.443 & 0.137 & 2.865 & -1.26 & -1.59 \\
\hline & 7/23/99 & 31.7 & 297 & 0.02 & 7.69 & 0.366 & 0.056 & 0.221 & 2.506 & 0.397 & 0.005 & 2.616 & 1.15 & 11.25 \\
\hline & 8/17/99 & 30.3 & 287 & 0.01 & & 0.276 & 0.056 & 0.200 & 2.483 & 0.289 & 0.004 & 2.579 & -0.18 & 5.76 \\
\hline & 9/9/99 & 28 & 254 & 0.00 & 8.26 & 0.261 & 0.044 & 0.184 & 2.180 & 0.266 & 0.007 & 2.327 & -1.26 & -5.31 \\
\hline & 7/16/08 & 26.9 & & 13.8 & 7.40 & 7.320 & 0.065 & 0.923 & 6.190 & 10.37 & 0.443 & 3.956 & 2.62 & -1.29 \\
\hline & $9 / 13 / 08$ & 29.8 & 317.1 & 0.10 & 7.87 & 0.617 & 0.038 & 0.253 & 2.084 & 0.510 & 0.003 & & 0.16 & -0.33 \\
\hline & $10 / 6 / 08$ & 29.4 & 306.3 & 0.10 & 7.64 & 0.438 & 0.023 & 0.197 & 2.029 & 0.700 & 0.000 & 3.047 & & \\
\hline & $1 / 6 / 09$ & 23.1 & 406.5 & 0.20 & 7.45 & 0.935 & 0.030 & 0.287 & 3.094 & 1.100 & 0.010 & 3.653 & 1.60 & 11.93 \\
\hline & 2/12/09 & 19.0 & 1036 & 0.60 & 7.33 & 4.513 & 0.041 & 0.650 & 5.675 & 7.090 & 0.010 & 3.930 & 1.40 & 13.39 \\
\hline & $6 / 11 / 09$ & 29.0 & 531 & 0.20 & 7.51 & 1.048 & 0.031 & 0.294 & 2.553 & & & & & \\
\hline & 8/13/09 & & & & & 0.665 & 0.032 & 0.229 & 2.124 & & & & & \\
\hline & $1 / 5 / 12$ & 19.1 & 427 & 0.33 & 7.88 & 1.309 & 0.022 & 0.322 & 3.595 & 2.003 & 0.010 & 5.000 & 1.81 & 16.61 \\
\hline
\end{tabular}




\begin{tabular}{|c|cccccccccccccc|}
\hline $\begin{array}{c}\text { Site } \\
\text { Name }\end{array}$ & $\begin{array}{c}\text { Sample } \\
\text { Date }\end{array}$ & $\begin{array}{c}\mathrm{T} \\
\left({ }^{\circ} \mathrm{C}\right)\end{array}$ & $\begin{array}{c}\text { Cond } \\
(\mu \mathrm{S})\end{array}$ & $\begin{array}{c}\mathrm{Sal} \\
(\mathrm{ppt})\end{array}$ & $\mathrm{pH}$ & $\mathrm{Na}^{+}$ & $\mathrm{K}^{+}$ & $\mathrm{Mg}^{2+}$ & $\mathrm{Ca}^{2+}$ & $\mathrm{Cl}^{-}$ & $\mathrm{SO}_{4}{ }^{2-}$ & $\mathrm{Alk}$ & $\begin{array}{c}\delta^{18} \mathrm{O} \\
\% 0\end{array}$ & $\begin{array}{c}\delta \mathrm{D} \\
\% 0\end{array}$ \\
\hline TS3_SW & $5 / 10 / 12$ & 31.3 & 437 & 0.20 & 7.88 & 1.379 & 0.052 & 0.372 & 2.386 & 1.633 & 0.015 & 2.713 & -0.14 & -4.98 \\
& $6 / 13 / 12$ & 29.2 & 298 & 0.10 & 7.69 & 0.488 & 0.024 & 0.210 & 2.137 & 0.573 & 0.001 & 2.443 & -0.08 & -3.77 \\
& $7 / 12 / 12$ & 28.2 & 265 & 0.10 & 8.70 & 0.378 & 0.022 & 0.196 & 2.105 & 0.482 & 0.000 & 2.186 & 0.11 & -2.59 \\
\hline
\end{tabular}


B.4. TS/Ph-3 Groundwater (TS3_GW)

\begin{tabular}{|c|c|c|c|c|c|c|c|c|c|c|c|c|c|c|}
\hline $\begin{array}{c}\text { Site } \\
\text { Name }\end{array}$ & $\begin{array}{c}\text { Sample } \\
\text { Date }\end{array}$ & $\begin{array}{c}\mathrm{T} \\
\left({ }^{\circ} \mathrm{C}\right)\end{array}$ & $\begin{array}{l}\text { Cond } \\
(\mathrm{mS})\end{array}$ & $\begin{array}{c}\text { Sal } \\
(\mathrm{ppt})\end{array}$ & $\mathrm{pH}$ & $\mathrm{Na}^{+}$ & $\mathrm{K}^{+}$ & $\mathrm{Mg}^{2+}$ & $\mathrm{Ca}^{2+}$ & $\mathrm{Cl}^{-}$ & $\mathrm{SO}_{4}{ }^{2-}$ & Alk & $\begin{array}{c}\delta^{18} \mathrm{O} \\
\% 0\end{array}$ & $\begin{array}{l}\delta \mathrm{D} \\
\% 0\end{array}$ \\
\hline \multirow[t]{22}{*}{ TS3_GW } & $12 / 16 / 97$ & 26 & 0.44 & 0.20 & 7.08 & 0.387 & 0.110 & 0.297 & 4.571 & 0.383 & 0 & 4.802 & -1.90 & -8.37 \\
\hline & $2 / 4 / 98$ & 24.2 & 0.46 & 0.20 & & 0.381 & 0.107 & 0.351 & 4.714 & 0.367 & 0 & 4.466 & -1.85 & -7.72 \\
\hline & $2 / 25 / 98$ & 23.1 & 0.45 & 0.20 & 6.74 & 0.326 & 0.100 & 0.309 & 3.933 & 0.374 & 0 & 4.667 & -1.97 & -6.53 \\
\hline & $4 / 3 / 98$ & 25.9 & 0.45 & 0.20 & 6.77 & 0.367 & 0.097 & 0.305 & 4.457 & 0.375 & 0 & 3.279 & -1.74 & -6.99 \\
\hline & $6 / 4 / 98$ & 27.4 & 0.53 & 0.20 & 6.75 & 0.341 & 0.116 & 0.330 & 4.611 & 0.422 & $1 \mathrm{E}^{-03}$ & 4.696 & -2.12 & -11.39 \\
\hline & 7/23/98 & 26.4 & 0.44 & 0.20 & 6.21 & 0.337 & 0.107 & 0.333 & 5.079 & 0.416 & 0 & 3.159 & -1.69 & -5.97 \\
\hline & $9 / 3 / 98$ & 27.2 & 0.45 & 0.20 & 7.29 & 0.346 & 0.077 & 0.326 & 4.291 & 0.426 & 0 & 3.512 & -1.87 & -5.50 \\
\hline & $11 / 18 / 98$ & & & & & 0.344 & 0.100 & 0.317 & 3.665 & 0.540 & 0.013 & 3.355 & -1.84 & -9.14 \\
\hline & $12 / 13 / 98$ & 26.7 & & & 5.43 & 0.375 & 0.107 & 0.283 & 3.252 & 0.421 & 0 & & -1.92 & -7.89 \\
\hline & 2/11/99 & 25.6 & 0.44 & 0.20 & 7.33 & 0.333 & 0.107 & 0.292 & 4.219 & 0.450 & $5 \mathrm{E}^{-03}$ & 3.636 & -1.64 & -6.47 \\
\hline & 3/17/99 & 24.9 & 0.44 & 0.20 & 7.64 & 0.357 & 0.110 & 0.256 & 4.230 & 0.411 & $1 \mathrm{E}^{-03}$ & 2.980 & -0.55 & -4.81 \\
\hline & 4/22/99 & 27 & 0.44 & 0.20 & 7.58 & 0.372 & 0.090 & 0.248 & 4.284 & 0.445 & $4 \mathrm{E}^{-03}$ & 3.120 & -1.68 & -11.48 \\
\hline & $5 / 21 / 99$ & 25.6 & 0.44 & 0.20 & 7.32 & 0.366 & 0.104 & 0.291 & 4.252 & 0.409 & 0 & 3.766 & -1.80 & -7.87 \\
\hline & 6/24/99 & 25.5 & 0.47 & 0.00 & 7.18 & 0.366 & 0.107 & 0.258 & 4.228 & 0.415 & 0 & 3.790 & -1.82 & -5.82 \\
\hline & 7/23/99 & 25.9 & 0.46 & 0.13 & 7.03 & 0.352 & 0.102 & 0.294 & 4.257 & 0.413 & $2 \mathrm{E}^{-03}$ & 2.122 & -1.80 & -5.79 \\
\hline & 8/17/99 & 26.1 & 0.47 & 0.13 & & 0.354 & 0.102 & 0.262 & 4.287 & 0.410 & $8 \mathrm{E}^{-04}$ & 3.821 & -1.85 & -7.29 \\
\hline & 9/9/99 & 26.3 & 0.47 & 0.13 & 7.40 & 0.349 & 0.099 & 0.285 & 4.244 & 0.417 & $6 \mathrm{E}^{-04}$ & 3.717 & -1.87 & -6.26 \\
\hline & $2 / 25 / 98$ & 23.1 & 0.45 & 0.20 & 6.74 & 0.327 & 0.099 & 0.311 & 3.865 & 0.371 & $3 \mathrm{E}^{-03}$ & 5.153 & -1.93 & -6.42 \\
\hline & 7/16/08 & 26.4 & & 10.5 & 6.58 & & & & & 211.7 & 9.31 & 7.506 & & \\
\hline & $10 / 6 / 08$ & 27.1 & 24.1 & 14.0 & 6.55 & 165.3 & 1.788 & 35.58 & 29.54 & & & 7.676 & & \\
\hline & $1 / 6 / 09$ & 25.8 & 10.5 & 5.8 & 6.51 & 167.0 & 1.670 & 36.04 & 28.76 & 216.1 & 9.46 & 10.36 & 1.21 & 7.67 \\
\hline & $2 / 12 / 09$ & 24.5 & 10.0 & 5.7 & & 166.3 & 1.604 & 35.65 & 28.46 & 216.1 & 9.47 & 7.260 & 1.08 & 6.69 \\
\hline
\end{tabular}




\begin{tabular}{|c|cccccccccccccc|}
\hline $\begin{array}{c}\text { Site } \\
\text { Name }\end{array}$ & $\begin{array}{c}\text { Sample } \\
\text { Date }\end{array}$ & $\begin{array}{c}\mathrm{T} \\
\left({ }^{\circ} \mathrm{C}\right)\end{array}$ & $\begin{array}{c}\text { Cond } \\
(\mathrm{mS})\end{array}$ & $\begin{array}{c}\mathrm{Sal} \\
(\mathrm{ppt})\end{array}$ & $\mathrm{pH}$ & $\mathrm{Na}^{+}$ & $\mathrm{K}^{+}$ & $\mathrm{Mg}^{2+}$ & $\mathrm{Ca}^{2+}$ & $\mathrm{Cl}^{-}$ & $\mathrm{SO}_{4}^{2-}$ & $\mathrm{Alk}$ & $\begin{array}{c}\delta^{18} \mathrm{O} \\
\% 0\end{array}$ & $\begin{array}{c}\delta \mathrm{D} \\
\% 0\end{array}$ \\
\hline \multirow{2}{*}{$\mathrm{TS3}{ }_{-} \mathrm{GW}$} & $6 / 11 / 09$ & 25.0 & 22.9 & 13.9 & 6.54 & 166.1 & 1.719 & 36.02 & 28.14 & & & & & \\
& $8 / 13 / 09$ & & & & & 159.2 & 1.673 & 34.24 & 26.77 & & & & & \\
\cline { 2 - 14 } & $1 / 5 / 12$ & 24.3 & 11.4 & 7.5 & 7.04 & 81.7 & 1.538 & 15.38 & 19.67 & 106 & 2.73 & 6.053 & 1.06 & 9.65 \\
& $2 / 10 / 12$ & & & 7.0 & 6.80 & 88.2 & 0.755 & 16.44 & 19.37 & 111.5 & 3.09 & 6.543 & 1.10 & 9.93 \\
& $5 / 10 / 12$ & 24.6 & 21.3 & 12.9 & 6.67 & 173.8 & 2.093 & 39.16 & 27.97 & 216.6 & 7.13 & 9.866 & 0.44 & 7.55 \\
& $6 / 13 / 12$ & 25.9 & 21.6 & 12.7 & 6.71 & 170.9 & 2.070 & 38.42 & 27.39 & 211.0 & 6.95 & 3.686 & 0.88 & 6.43 \\
& $7 / 12 / 12$ & 25.4 & 22.2 & 13.3 & 6.18 & 166.5 & 2.127 & 38.08 & 27.31 & 223.3 & 6.97 & 8.116 & 0.81 & 8.83 \\
\hline
\end{tabular}


APPENDIX C. Long term ion concentrations for FCE-LTER sites, TS/Ph-1, TS/Ph-2, TS/Ph-3, TS/Ph-6, and TS/Ph-7 -graphsC.1.1. TS/Ph-1 Calcium (August 2008 - December 2011)

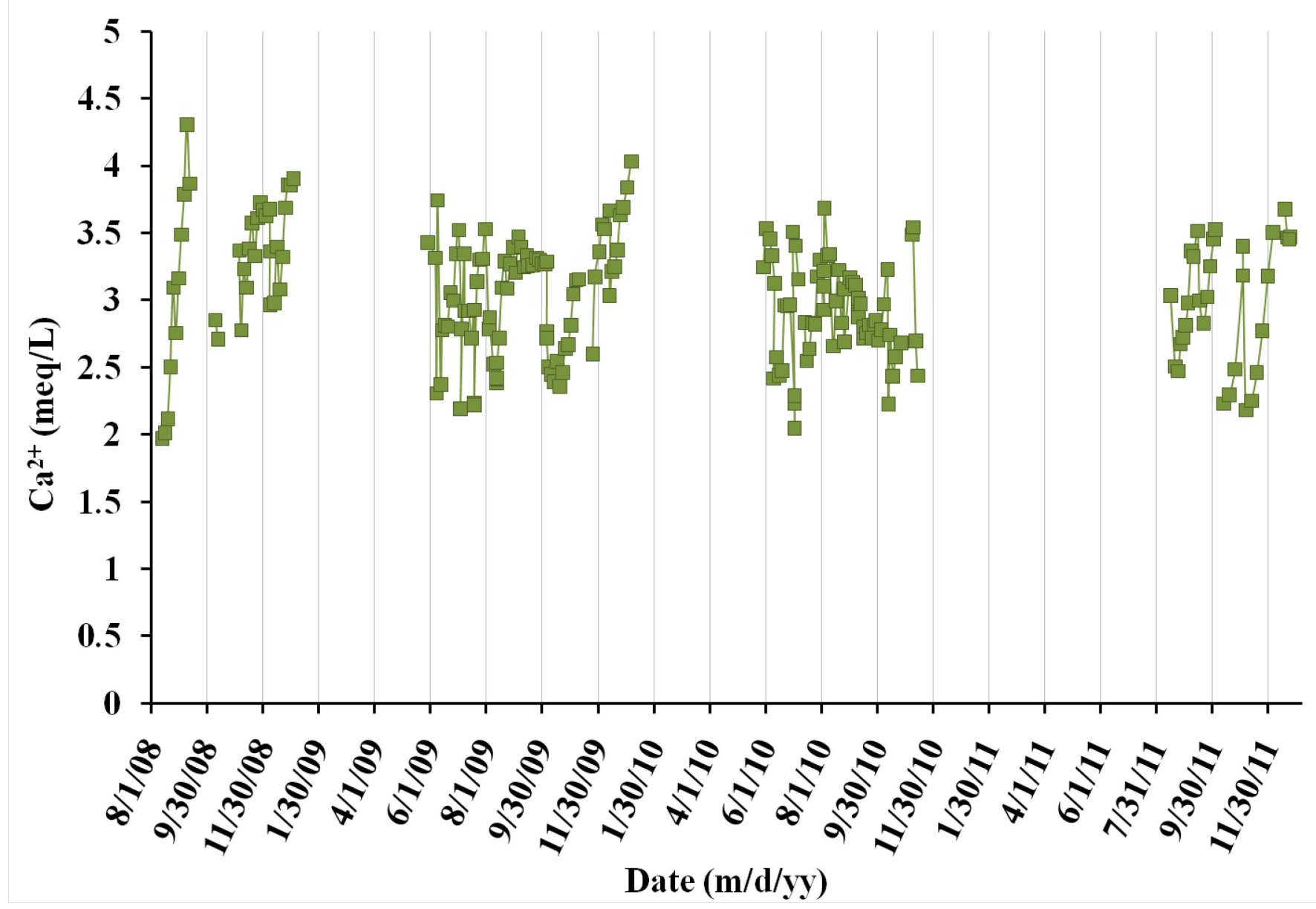


C.1.2. TS/Ph-1 Chloride (August 2008 - December 2011)

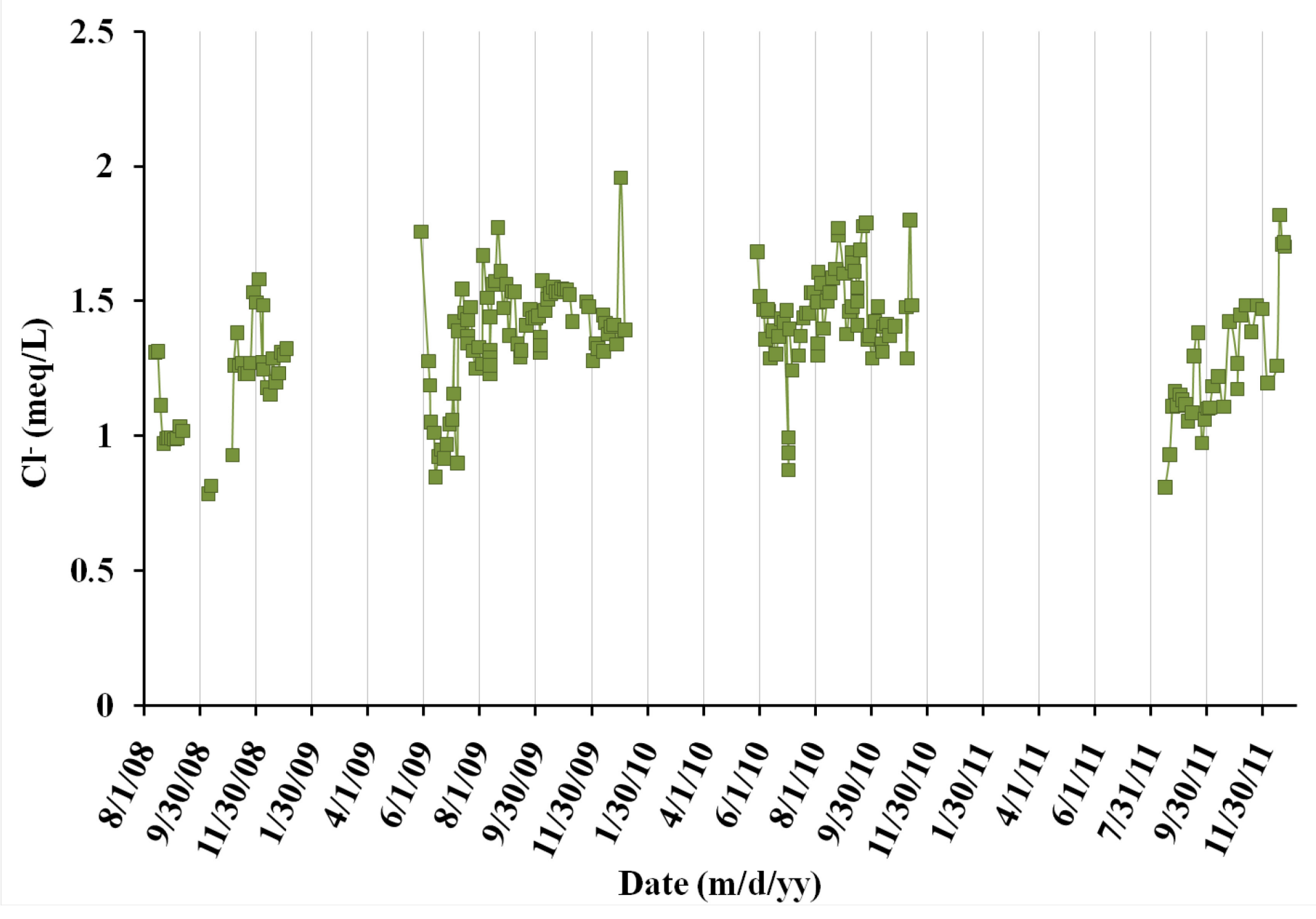


C.2.1. TS/Ph-2 Calcium (August 2008 - December 2011)

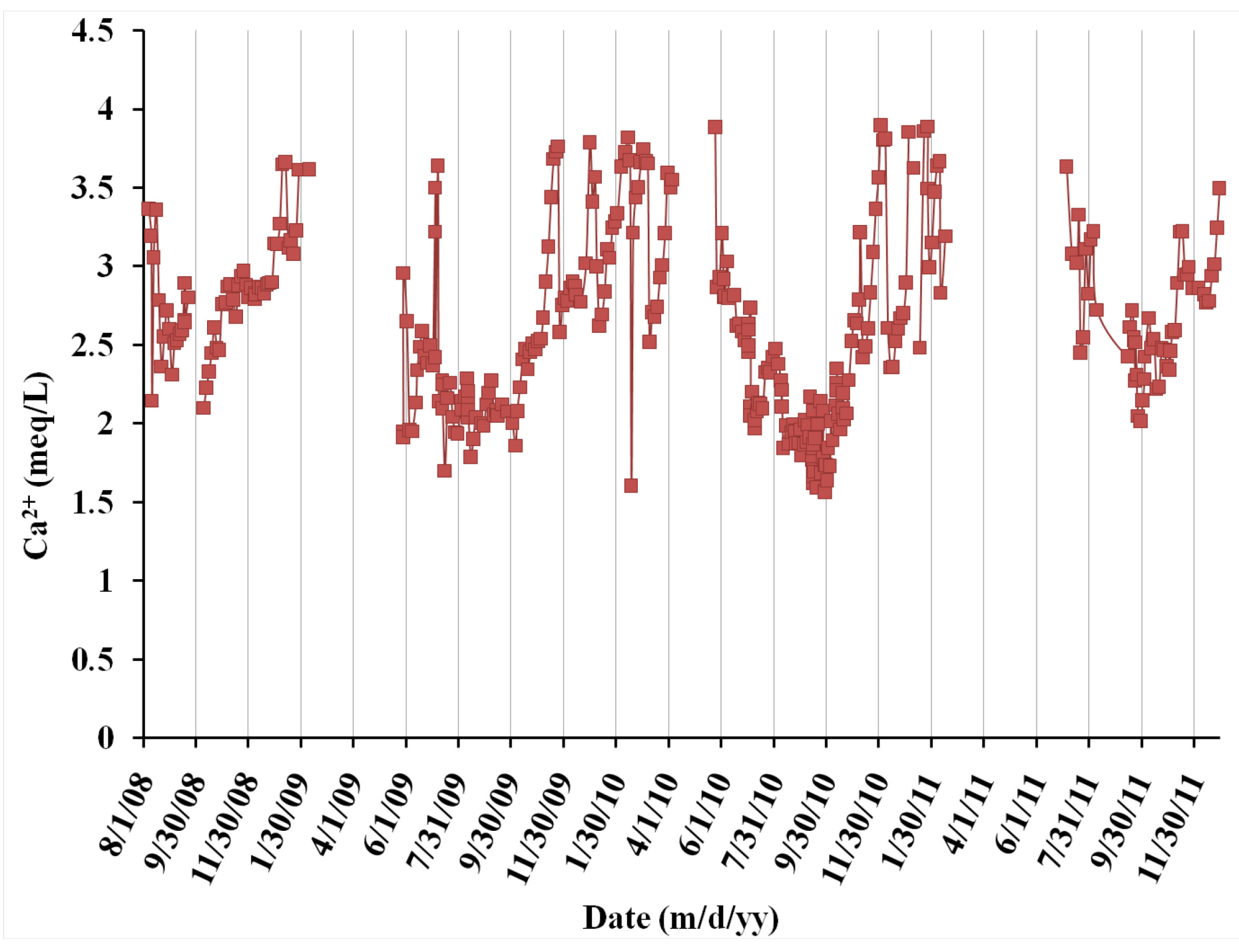


C.2.2. TS/Ph-2 Chloride (August 2008 - December 2011)

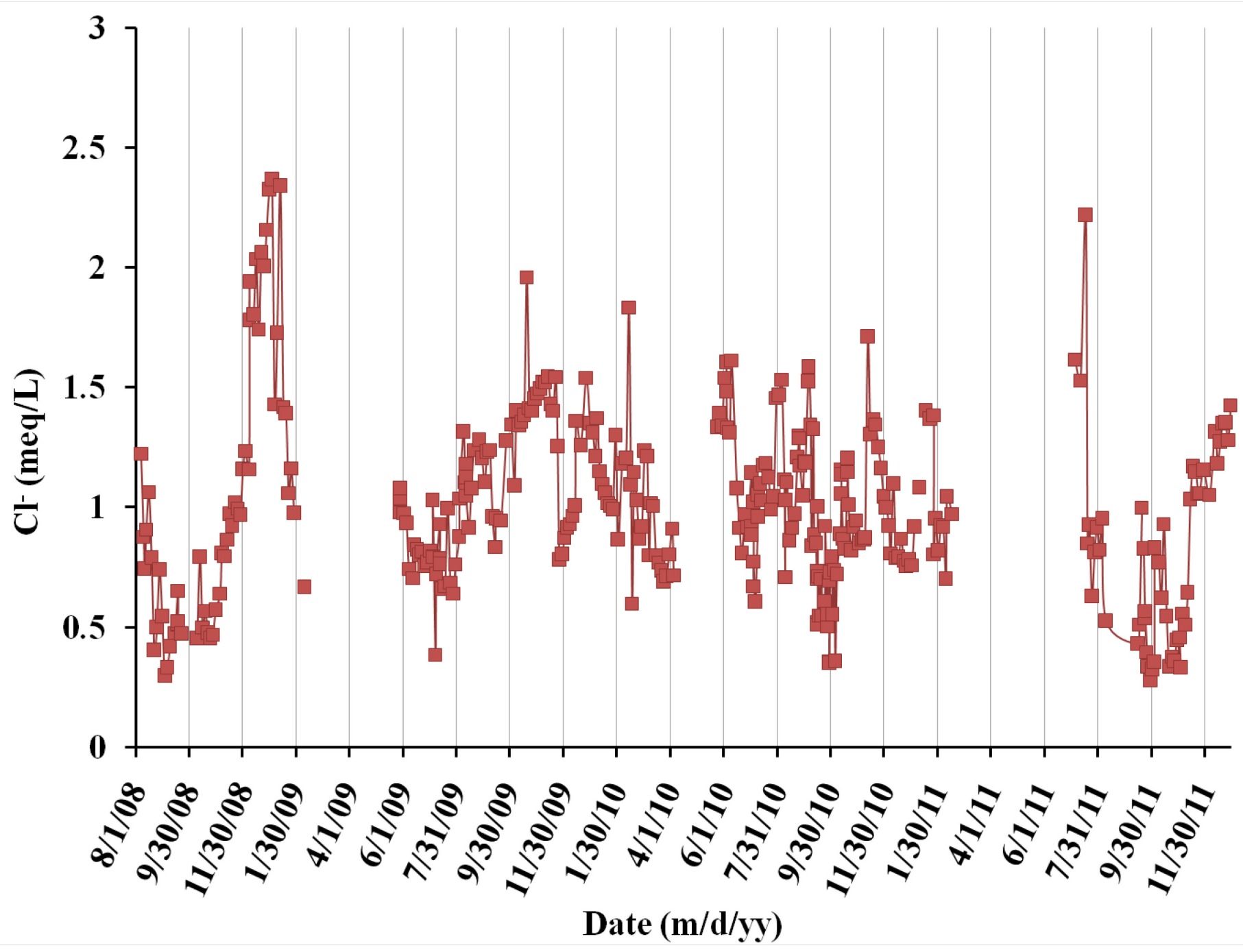


C.3.1. TS/Ph-3 Calcium (August 2008 - December 2011)

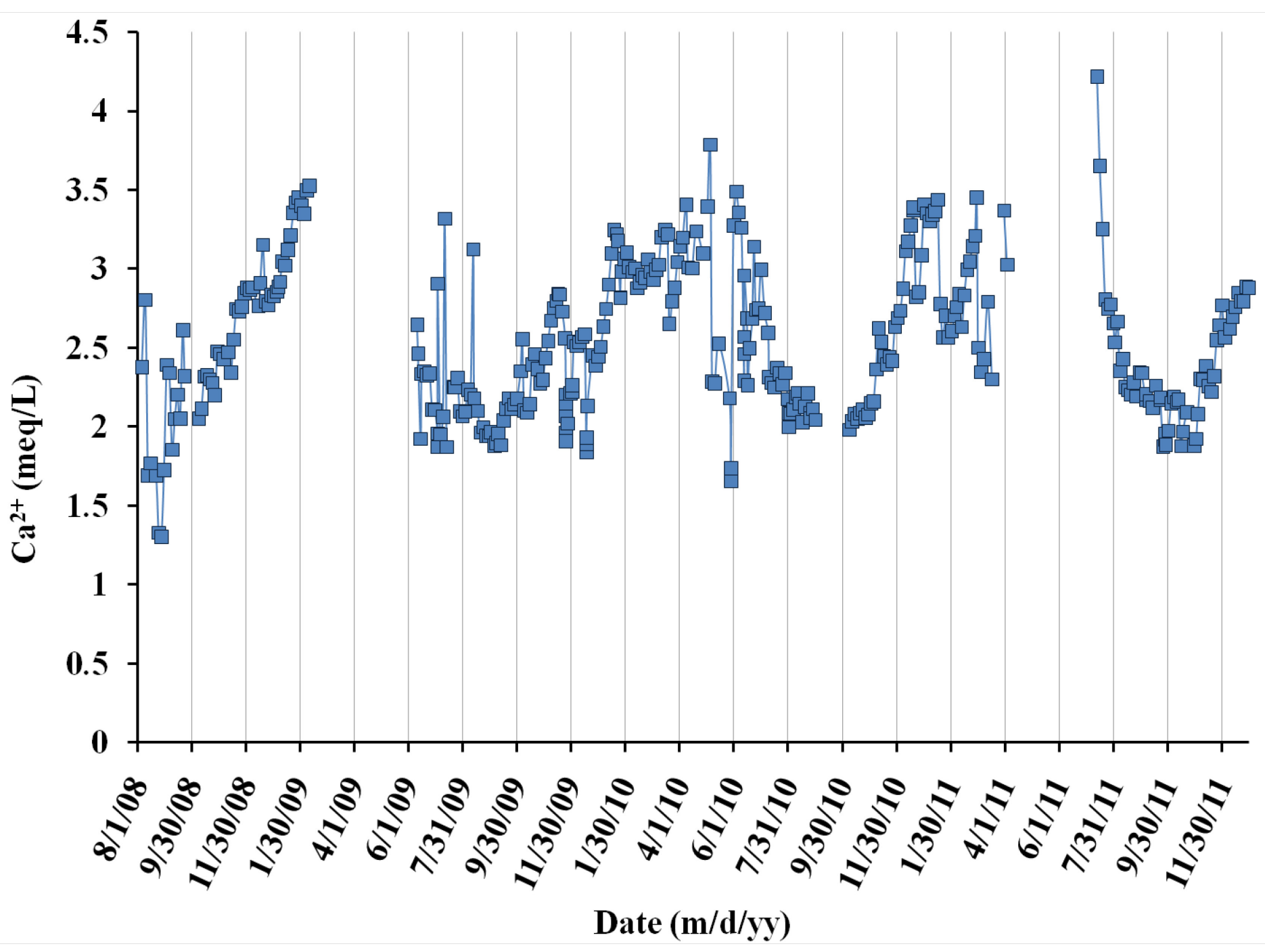


C.3.2. TS/Ph-3 Chloride (August 2008 - December 2011)

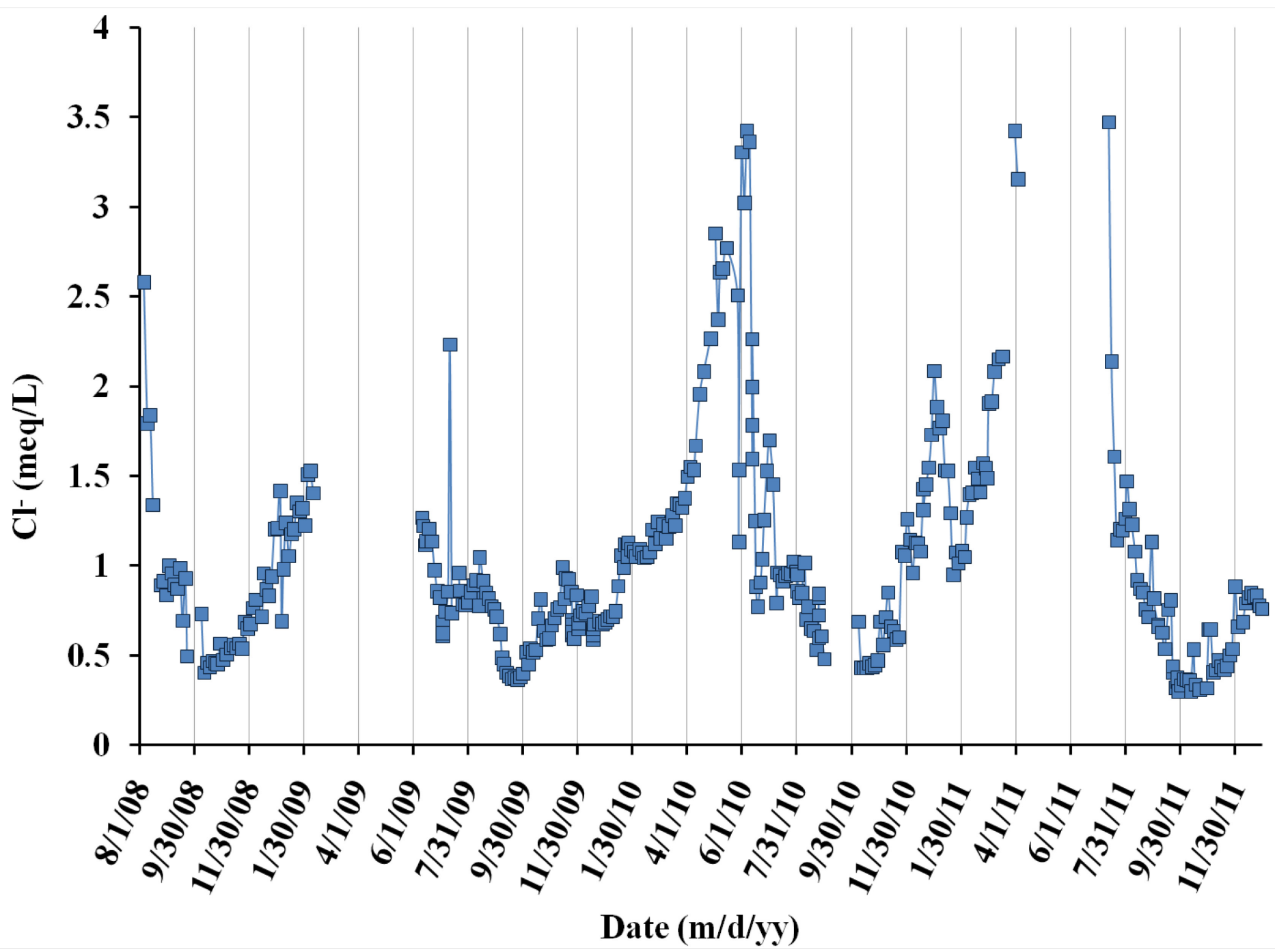


C.4.1. TS/Ph-6 Calcium (February 2008 - December 2011)

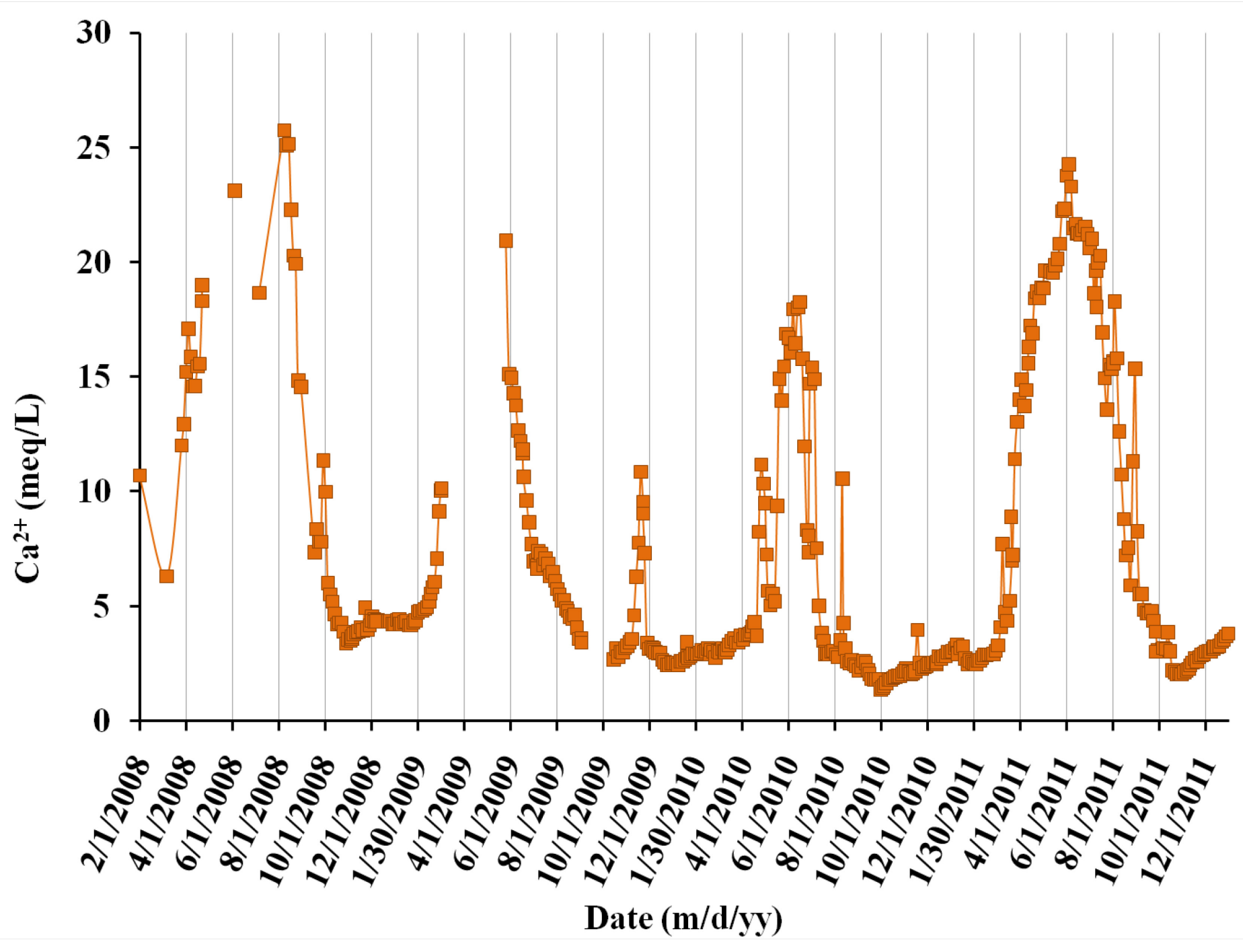


C.4.2. TS/Ph-6 Chloride (February 2008 - December 2011)

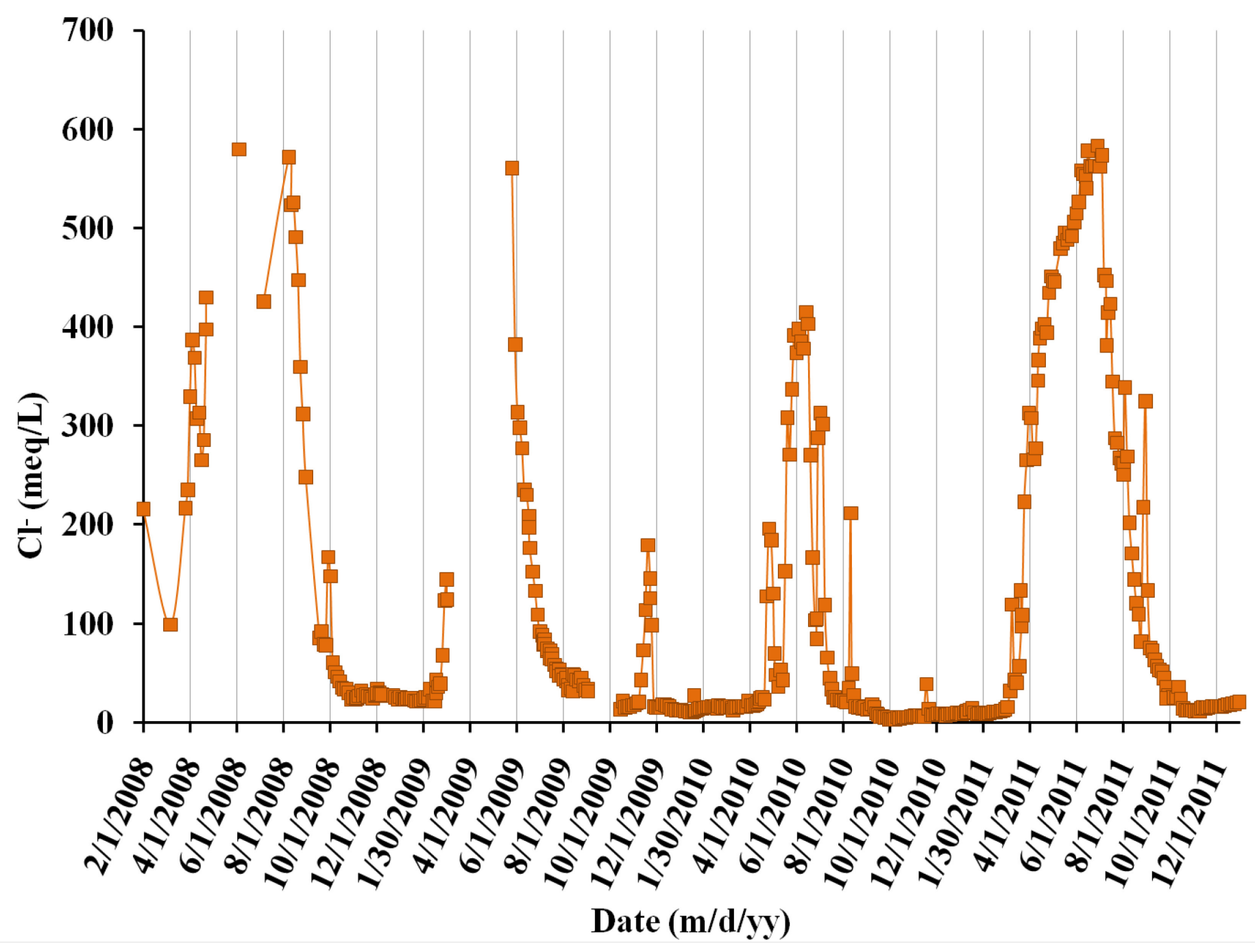


C.5.1. TS/Ph-7 Calcium (February 2008 - December 2011)

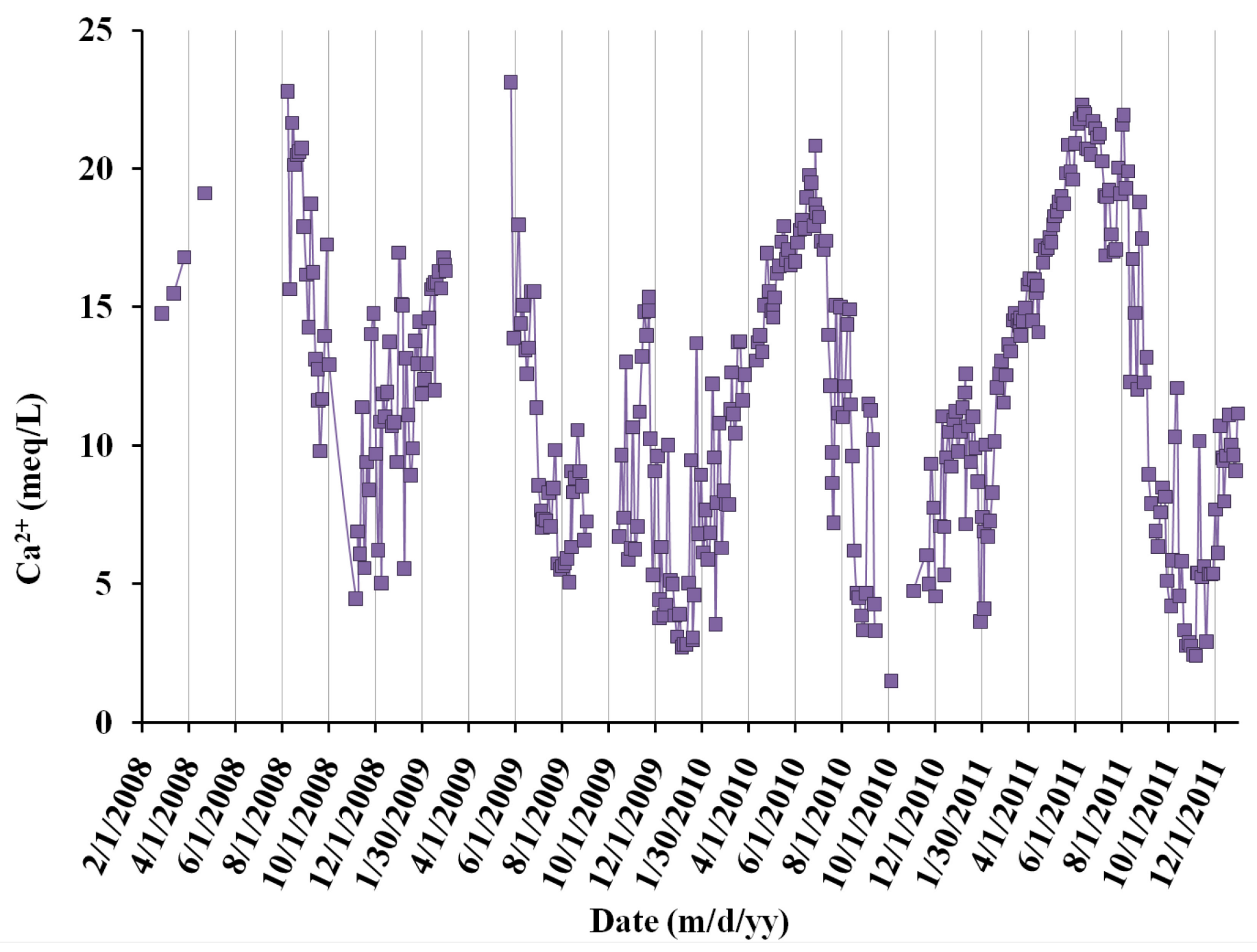


C.5.2. TS/Ph-7 Chloride (February 2008 - December 2011)

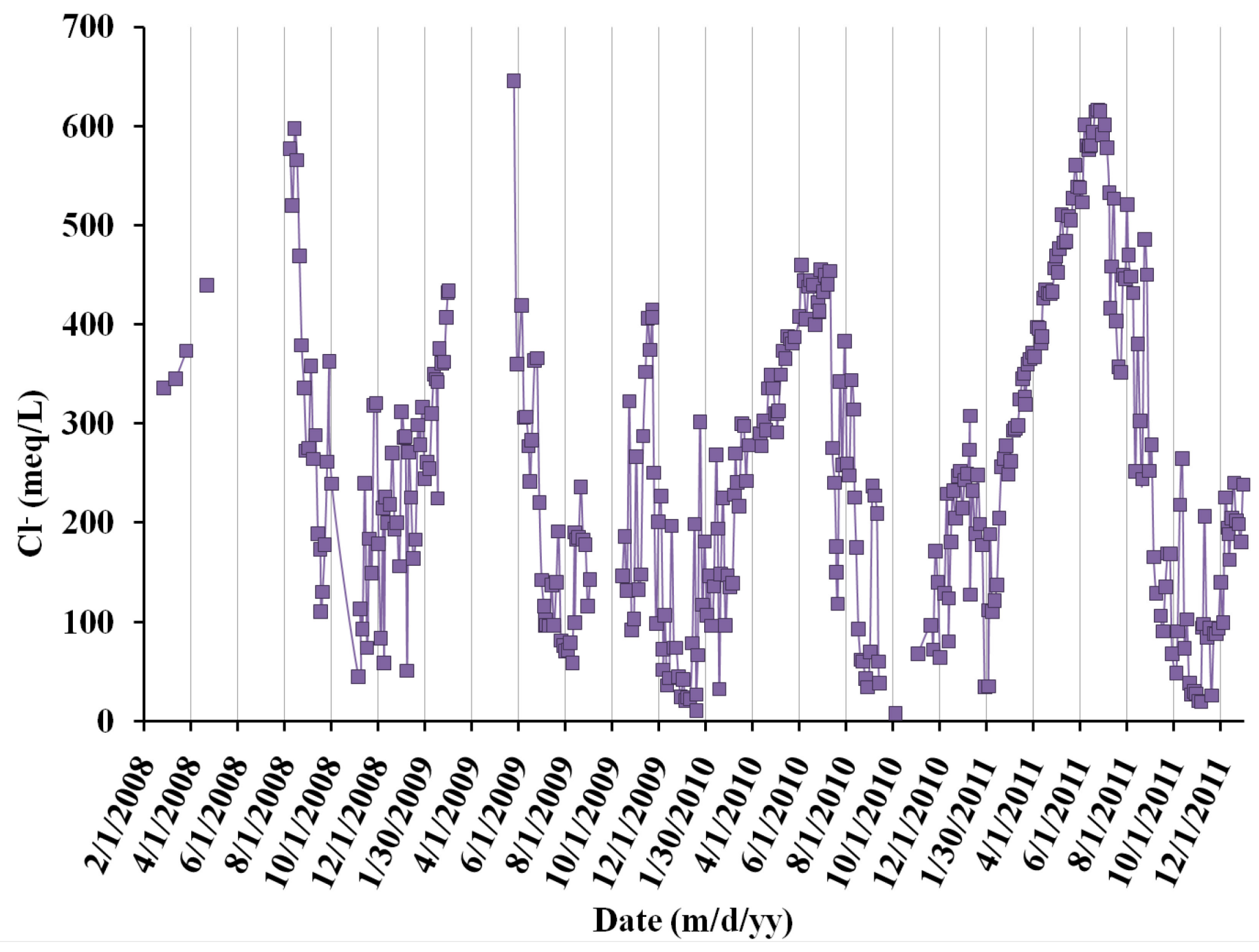


APPENDIX D. Python script for GIS batch processing of raster layers of water level, water depth, change in storage, precipitation, and evapotranspiration.

D.1. Taylor Model

\# Taylor_Model_1.py

\# Created on: 2012-05-15

\# (Generated by Estefania Sandoval)

\# Discription: This script is used to create a kriging representation of point water level, evapotranspiration, water depth, change in storage.

\# and evapotranspiration data on a monthly scale. Layers are clipped to only include water depth values greater than 0 .

\# Import modules

import arcpy

from arcpy import env

from arcpy.sa import *

\# Set Work Environment, this should be your main geodatabase

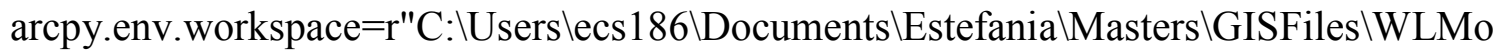
nthly.gdb"

\# Set Scratch Work Environment, this should be your main geodatabase

arcpy.env.scratchWorkspace $=" \mathrm{C}: \backslash U$ sers $\backslash$ ecs $186 \backslash$ Documents $\backslash$ Estefania $\backslash$ Masters $\backslash G I S F i l e s \backslash S$ cratch.gdb"

\# Set input varibles to simplify text

TSboundary="taylormask"

\# Set Work Enironment Characteristics(snap, cellsize, and Mask)

arcpy.env.outputCoordinateSystem = "taylormask"

arcpy.env.extent $=$ "taylormask" 
arcpy.env.snapRaster $=$ "taylormask" \# Watershed boundary raster

arcpy.env.cellSize $=" 400 " \quad$ \# Cell Size of all Rasters Produced

arcpy.env.mask = "taylormask" \# Watershed boundary raster

\# Check out the ArcGIS Spatial Analyst extension license

arcpy.CheckOutExtension("Spatial")

\# Kriging: used for water level and evapotranspiration data. Water level used for this example.

Stations $=$ "STGFMonth"

fieldlist $=$ arcpy.ListFields(Stations,"D*")

for field in fieldlist:

fname $=$ field.name

outKrig = Kriging(Stations,fname,"Spherical",400,"VARIABLE 12")

arcpy.CopyRaster_management(outKrig,fname)

\# Raster Calculation: Water Level raster - KHAED (personal DEM) to get Water Depth raster.

ylist $=[1,2,3,4,5,6,7,8]$

for yy in ylist:

for a in range $(1,10)$ :

$$
\begin{aligned}
& \text { RastFst= Raster("D0"+str(yy)+"0"+ } \operatorname{str}(a)+" 01 ") \\
& \text { GroundEle=Raster("KHAED") } \\
& \text { WLDif = RastFst - GroundEle }
\end{aligned}
$$


arcpy.CopyRaster_management(WLDif,"WD0"+str(yy)+"0" + $\operatorname{str}(\mathrm{a})+" 01 ")$

\# Con to make values less than 0 into NoData while retaining values greater than 0 , these rasters were used

\#for Volume in the flushing time calculations.

ylist $=[1,2,3,4,5,6,7,8,9]$

for yy in ylist:

for a in range $(0,3)$ :

$$
\begin{aligned}
& \text { WD }=\text { Raster("WD0"+str(yy)+"1"+str(a)+"01") } \\
& \text { outCon }=\text { Con(WD > 0, WD, NoData) } \\
& \text { arcpy.CopyRaster_management(outCon,"E0"+str(yy)+"1" + str(a)+"01") }
\end{aligned}
$$

\# Con to make values less than 0 into 0 while retaining values greater than $0 \#$

ylist $=[1,2,3,4,5,6,7,8,9]$

for yy in ylist:

for a in range $(0,3)$ :

$$
\begin{aligned}
& \text { WD= Raster("WD1"+str(yy)+"1"+str(a)+"01") } \\
& \text { outCon }=\text { Con(WD > 0, WD, 0) } \\
& \text { arcpy.CopyRaster_management(outCon,"Con_WD1"+str(yy)+"1" }
\end{aligned}
$$$$
+\operatorname{str}(\mathrm{a})+" 01 ")
$$

\#Change in storage\#

ylist $=[1,2,3,4,5,6,7,8,9]$

for yy in ylist:

for a in range $(1,9)$ :

$$
\text { Con1= Raster("Con_WD0"+str(yy)+"0"+str(a)+"01") }
$$




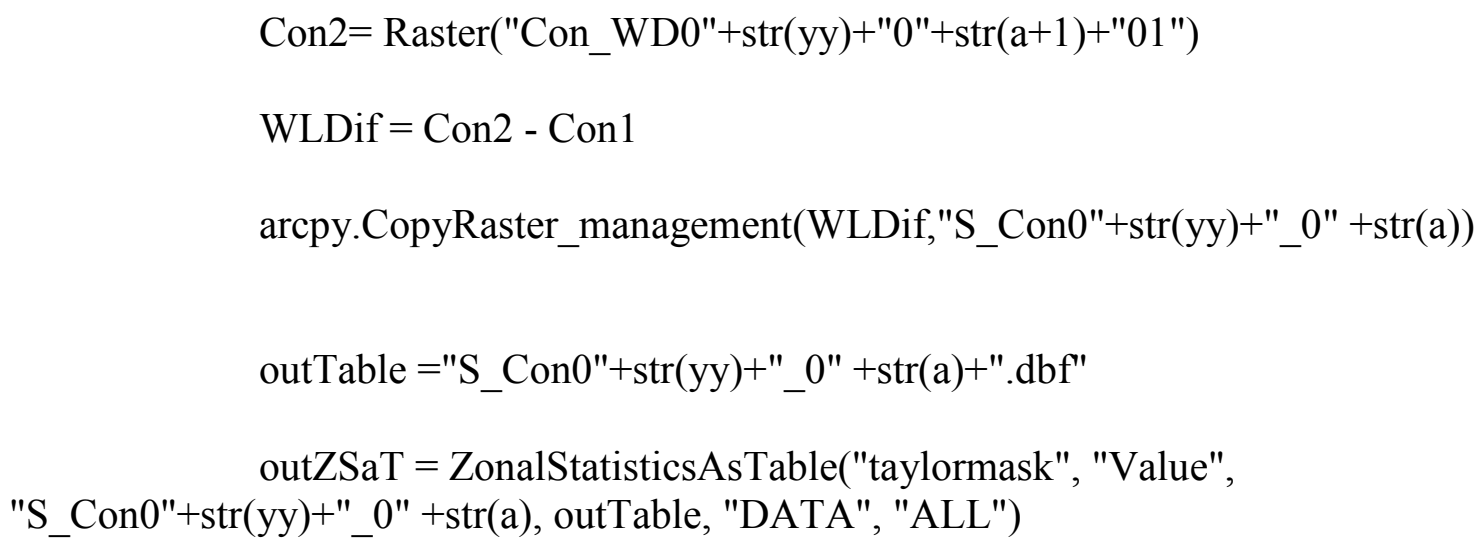

\#Zonal Statistics on rasters, the change in storage (Con_WDYYMM01) were used as example\#

ylist $=[1,2,3,4,5,6,7,8,9]$

for yy in ylist:

for a in range $(10,12)$ :

$$
\begin{aligned}
& \text { WD= Raster("Con_WD0"+str(yy)+str(a)+"01") } \\
& \text { outTable ="Con_WD0"+str(yy)+"_"+str(a)+".dbf" } \\
& \text { outZSaT = ZonalStatisticsAsTable("taylormask", "Value", WD, outTable, }
\end{aligned}
$$
"DATA", "ALL") 
D.2. Precipitation

\# Precip_SQLFeature_ThP_Rast.py

\# Created on: 2012-04-10

\# (Generated by Pamela Sullivan)

\# Description: This script is used to call up data from a point feature in a geodatabase

\# and create Thiessen Polygons and convert them into a raster

\# Import modules

import arcpy

from arcpy import env

from arcpy.sa import*

\# Set Work Environment, this should be your main geodatabase

arcpy.env.workspace $=r " \mathrm{C}: \backslash$ Users $\backslash$ ecs $186 \backslash$ Documents $\backslash$ Estefania $\backslash$ Masters $\backslash$ GISFiles $\backslash$ Precip.g $\mathrm{db} "$

\# Set Scrach Work Environment, this should be your main geodatabase

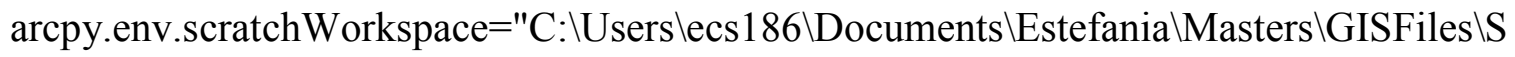
cratch.gdb"

\# Set input varibles to simplify text

TSboundary="taylormask" 
\# Set Work Enironment Characteristics(snap, cellsize, and Mask)

arcpy.env.snapRaster $=$ "taylormask" \# Watershed boundary raster

arcpy.env.cellSize $=" 400 " \quad$ \# Cell Size of all Rasters Produced

arcpy.env.mask = "taylormask" \# Watershed boundary raster

\# Check out the ArcGIS Spatial Analyst extension license

arcpy.CheckOutExtension("Spatial")

precip $=$ "Precip_Stations"

\# List fields with in the Precipiation data sheet

fieldlist $=$ arcpy.ListFields(precip,"M0904")

for field in fieldlist:

fname $=$ field.name

delimitedfield = arcpy.AddFieldDelimiters(precip,fname) \# Insures the query will use the correct field

$$
\text { query = delimitedfield + "IS NOT NULL" }
$$

thifield = arcpy.Select_analysis(precip,"thi_"+fname,query) \# Creates a new field where null values were removed from the the given field of data

outThp $=$ arcpy.CreateThiessenPolygons_analysis("thi_"+fname,"ThyP_"+fname, "ALL") \# Creates thiessen polygons with null value removed for specific field outRast= arcpy.PolygonToRaster_conversion("ThyP_"+fname, fname,"PRast_"+fname, ,CELL_CENTER", "NONE", "400")

outExtractByMask = ExtractByMask("PRast_"+fname, ,taylormask") outExtractByMask.save("Mask_"+fname) 
outTable ="Mask_"+fname+".dbf"

outZStat = ZonalStatisticsAsTable("taylormask", "Value", "Mask_"+fname, outTable, "DATA", "ALL") 